UNIVERSIDADE DE BRASÍLIA

FACULDADE DE TECNOLOGIA

DEPARTAMENTO DE ENGENHARIA CIVIL E AMBIENTAL

\title{
ANÁLISE SISTÊMICA DA SEGREGAÇÃO NA CADEIA LOGÍSTICA DA SOJA APÓS O ADVENTO E A DIFUSÃO DOS TRANSGÊNICOS
}

FABRÍCIO OLIVEIRA LEITÃO

ORIENTADOR: SÉRGIO RONALDO GRANEMANN

TESE DE DOUTORADO EM TRANSPORTES

PUBLICAÇÃO: T.D-005/2014

BRASÍLIA/DF: NOVEMBRO - 2014 
UNIVERSIDADE DE BRASÍLIA

FACULDADE DE TECNOLOGIA

DEPARTAMENTO DE ENGENHARIA CIVIL E AMBIENTAL

ANÁLISE SISTÊMICA DA SEGREGAÇÃO NA CADEIA LOGÍSTICA DA SOJA APÓS O ADVENTO E A DIFUSÃO

DOS TRANSGÊNICOS

\section{FABRÍCIO OLIVEIRA LEITÃO}

TESE DE DOUTORADO SUBMETIDA AO DEPARTAMENTO DE ENGENHARIA CIVIL E AMBIENTAL DA FACULDADE DE TECNOLOGIA DA UNIVERSIDADE DE BRASÍLIA COMO PARTE DOS REQUISÍTOS NECESSÁRIOS PARA A OBTENÇÃO DO GRAU DE DOUTOR EM TRANSPORTES.

APROVADA POR:

Prof. Sérgio Ronaldo Granemann, Dr. (UnB)

(Orientador)

Prof. Adelaida Pallavicini Fonseca, Dra. (UnB)

(Examinadora Interna)

Prof. Fabiana Serra de Arruda, Dra. (UnB)

(Examinadora Interna)

Prof. Josemar Xavier de Medeiros, Dr. (UnB)

(Examinador Externo)

Prof. Paulo César Rodrigues Borges, Dr. (IESB)

(Examinador Externo)

DATA: BRASÍLIA/DF, 07 DE NOVEMBRO DE 2014 


\section{FICHA CATALOGRÁFICA}

\section{LEITÃO, FABRÍCIO OLIVEIRA}

Análise Sistêmica da Segregação na Cadeia Logística da Soja Após o Advento e a Difusão dos Transgênicos. [Distrito Federal] 2014.

xvi, 181p., 210 x 297 mm (ENC/FT/UnB, Doutor, Transportes, 2014).

Tese de Doutorado - Universidade de Brasília. Faculdade de Tecnologia.

Departamento de Engenharia Civil e Ambiental.

1. Segregação na Cadeia Logística da Soja

3. Cuidados e Procedimentos para a não Contaminação

I. ENC/FT/UnB
2. Análise Sistêmica

4. Tempos e Custos Adicionais

II. Título (série)

\section{REFERÊNCIA BIBLIOGRÁFICA}

LEITÃO, FABRÍCIO OLIVEIRA (2014). Análise Sistêmica da Segregação na Cadeia Logística da Soja Após o Advento e a Difusão dos Transgênicos. Tese de Doutorado em Transportes, Publicação T.TD - / 2014, Departamento de Engenharia Civil e Ambiental, Universidade de Brasília, Brasília, DF, 181p.

\section{CESSÃO DE DIREITOS}

AUTOR: Fabrício Oliveira Leitão.

TÍTULO: Análise Sistêmica da Segregação na Cadeia Logística da Soja Após o Advento e a Difusão dos Transgênicos.

GRAU: Doutor

ANO: 2014

É concedida à Universidade de Brasília permissão para reproduzir cópias desta Tese de Doutorado e para emprestar ou vender tais cópias somente para propósitos acadêmicos e científicos. O autor reserva outros direitos de publicação, e nenhuma parte desta Tese de Doutorado pode ser reproduzida sem autorização por escrito do autor.

Fabrício Oliveira Leitão

Avenida Governador Valadares n ${ }^{\circ} 2.985$, Divinéia.

38.610.000 Unaí - MG - Brasil. 


\section{AGRADECIMENTOS}

A todos os professores, servidores e colegas do Programa de Pós-Graduação em Transportes da Universidade de Brasília (PPGT/UnB), em especial à Lucinete, sempre prestativa e solícita nos momentos de que necessitei.

Aos meus amigos e colegas de trabalho, que sempre me incentivaram a seguir a vida acadêmica, em especial aos professores Ana Paula Pinto Viana, Daniel Azevedo Palma, Danilo Bijos, Domingos Sávio Spezia, Ivete Maria de Oliveira Alves, Helen Danyane Soares Caetano de Souza, Jussara Resende Costa Campos, Romualdo Neiva Gonzaga, Rômulo Caldeira de Souza Maia, Rosimeire Rosimeire Fernandes Cruz Pereira e Zeuman de Oliveira e Silva.

Aos meus amigos de longa data, André Lelis, Daniel Amaral, Dérick Martins, Kaio Caldeira, Kaique Caldeira, Murilo Wohlmuth, Rafael Amaral, Rafael Martins, Rafael Vaz, Raphael Greenhalgh, Samuel Rodrigues, Sérgio Pereira de Souza, Thiago Emílio e Vinícius Oliveira, que durante os anos de mestrado e doutorado estiveram ao meu lado, oferecendo apoio, incentivo, estímulo e alegria.

Aos meus amigos pesquisadores do departamento de Agronegócios da UnB, professores Karim Marini Thomé, Magali Costa Guimarães e Marlon Vinícius Brisola. Certamente, sem o incentivo e o conhecimento obtido por vocês, não teria a oportunidade de concluir este trabalho.

Aos meus pais Volnei e Alzira, meus irmãos Fernando e Cíntia, meus sobrinhos Fernando e Ana Laura, e ao cunhado Rodrigo, que sempre estiveram ao meu lado, dando-me carinho e apoio nos momentos difíceis.

Ao coordenador do Programa de Pós-Graduação em Transportes da Universidade de Brasília (PPGT/UnB), professor Paulo César Marques da Silva, quem me deu suporte sempre quando necessário, facilitando meu caminho rumo ao desenvolvimento da pesquisa de campo desta tese.

Aos professores membros da banca, que contribuíram de maneira definitiva no desenvolvimento deste trabalho em todas as suas fases, em especial à professora Adelaida, que acompanhou e participou da construção de todas as etapas, desde a entrevista do projeto submetido à seleção de doutorado até a defesa. E ao professor Josemar, pessoa que me acolheu como orientando no mestrado, e que sempre confiou em meu trabalho.

Ao meu orientador, que me guiou com muita seriedade, dedicação e maestria, norteandome rumo aos caminhos necessários para o alcance deste objetivo. Agradeço por seus conselhos, críticas e sugestões.

Ao Instituto de Ensino Superior Cenecista - INESC/CNEC Unaí - MG, Instituição da qual sou egresso, e que contribuiu vertiginosamente para minha formação acadêmica e profissional. 
A todos os produtores rurais, armazenadores/processadores, transportadores rodoviários, transportadores ferroviários e operadores portuários que disponibilizaram seu tempo para as entrevistas da pesquisa de campo.

Ao meu grande amor, Laís Bárbara Pereira Rodrigues, futura esposa e mãe dos meus filhos, minha companheira e maior fonte de inspiração para tudo que faço em minha vida. Obrigado pela compreensão, carinho e apoio nos momentos que tive de deixá-la para me dedicar a este trabalho. 


\title{
RESUMO
}

\section{ANÁLISE SISTÊMICA DA SEGREGAÇÃO NA CADEIA LOGÍSTICA DA SOJA APÓS O ADVENTO E A DIFUSÃO DOS TRANSGÊNICOS}

\author{
Autor: Fabrício Oliveira Leitão \\ Orientador: Sérgio Ronaldo Granemann \\ Programa de Pós-graduação em Transportes \\ Brasília, 07 de Novembro de 2014
}

Este trabalho buscou identificar as mudanças ocorridas na Cadeia Logística da Soja bem como os impactos aos elos que a compõe (produtores, armazenadores/processadores, transportadores rodoviários, operadores ferroviários e portuários), em decorrência do advento e da difusão da soja transgênica, sob uma ótica sistêmica dos problemas que envolvem sua segregação. Para isso, foram identificados os pontos críticos, os cuidados e procedimentos, e os tempos e custos adicionais necessários para a não contaminação da soja ao longo da Cadeia. A pesquisa apoiou-se nas contribuições teóricas trazidas pela Nova Economia Institucional e Economia dos Custos de Transação (emblematicamente a teoria dos contratos e a especificidade dos ativos necessários à segregação), e na literatura relacionada à Logística. O estudo foi de natureza exploratória, com abordagem qualitativa. Para a coleta de dados, foram utilizadas, como fontes primárias, entrevistas, utilizando como instrumento os questionários semiestruturados e, como fonte secundária, a documentação indireta. Foram realizadas 57 entrevistas aplicadas aos elos supracitados, utilizando a técnica de fluxogramas para o desenho de todos os processos logísticos que compõem a Cadeia Logística, envolvendo desde a compra da semente de soja até a colocação do produto livre de transgênicos nos portos para exportação. Os resultados obtidos possibilitaram concluir que os principais pontos críticos para a segregação são: (i) possibilidade da compra de semente contaminada; (ii) necessidade de limpeza do caminhão em todos os processos de carga e descarga; (iii) escolha da área onde a soja será plantada, bem como a necessidade do preparo e limpeza para o plantio; (iv) utilização de bordas de contenção para a separação das duas sojas na área plantada; (v) capacitação dos funcionários antes do plantio, colheita e armazenagem; (vi) necessidade de limpeza das plantadeiras e colheitadeiras, assim como de todos os ativos relacionados 
à armazenagem do produto no momento da entrada e expedição da soja livre de transgênicos; (vii) transbordo individual dos caminhões nos armazéns no momento da carga e descarga da soja; (viii) necessidade de limpeza dos contêineres dos trens e dos porões dos navios para recepção da soja livre de transgênicos. Os resultados permitiram concluir também que o elo armazenador/processador assume papel fundamental na coordenação de toda a logística da cadeia da soja, ampliando os seus limites no sentido "coaseano", pagando os prêmios para os agentes que conseguem fazer a segregação, passando a ser visto com um coordenador de contratos. Contratos estes que também assumem papel fundamental para a mitigação dos riscos de contaminação, pois estão sendo utilizados como mecanismos de incentivo/controle à segregação. Através da pesquisa de campo também foi constatado que os custos da segregação de toda a cadeia logística da soja, para a oferta de um produto puro, livre de transgênicos, foram de 8,39\%; e que o armazenador/processador recebe um prêmio real de 9,2\% pela segregação e gestão dos contratos ao longo da cadeia logística da soja. 


\title{
ABSTRACT \\ SYSTEMIC ANALYSIS OF SEGREGATION IN SUPPLY CHAIN AFTER THE ADVENT AND SPREAD OF TRANSGENIC SOYBEANS
}

\author{
Author: Fabrício Oliveira Leitão \\ Supervisor: Sérgio Ronaldo Granemann \\ Programa de Pós-graduação em Transportes \\ Brasília, 07 of November of 2014
}

This thesis aimed to identify changes in the Soybean Supply Chain as well as the impacts to the links that compose it (producers, storage / processors, hauliers, and rail and port operators) by the advent and spread of transgenic soybeans, under a systemic optical involving segregation, identification of the critical points, care and procedures, as well as the times and additional costs required for the non-contamination of soy along the chain. The theoretical framework was supported in this New Institutional Economics and Transaction Cost Economics (emblematically the theory of contracts and asset specificity required for segregation), and the theoretical basis of the literature related to Logistics. The study was exploratory in nature, with a qualitative approach. For data collection were used as primary sources, interviews, using semi structured questionnaires as support and as a secondary source, indirect documentation. Was applied 57 interviews, using the technique of flow charts for the design of all logistics processes that make up the supply chain, ranging from the purchase of soybean seed by placing the product free of transgenics in the ports for export. The results enabled us to conclude that the main critical points for segregation are: (i) possibility of buying contaminated seed; (ii) necessity of cleaning the truck at all loading and unloading processes; (iii) select the area to be planted soybeans, as well as the need for cleaning and preparation for planting; (iv) use of containment edges for the separation of the two soybean planted area; (v) employee training before planting, harvesting and storage; (vi) need of cleaning planters and harvesters, as well as all assets related to the storage of the product at the time of entry and shipment of GMO-free soybeans; (vii) individual transshipment trucks in warehouses at the time of loading and unloading of soybeans; (viii) need for cleaning of containers from trains and ships to receive free transgenic soybean. The results also concluded that the storer / processor link takes key role in coordinating all logistics of the 
soy chain, expanding your limits (based on Coase), paying premiums for agents who can make segregation, going to be seen with a coordinator contracts. Assume that these contracts also critical to mitigating the risks of contamination role, because they are being used as incentive mechanisms / control segregation. Through field research has also found that the costs of segregation of whole supply chain of soy, to offer a pure product, free of GMOs, were $8.39 \%$; and that the storer / processor receives a royal award of $5.53 \%$ by the segregation and the management of the contract along the supply chain of soy. 


\section{SUMÁRIO}

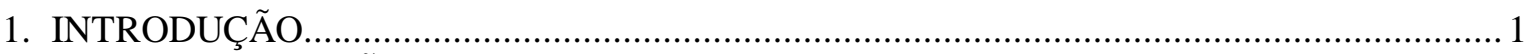

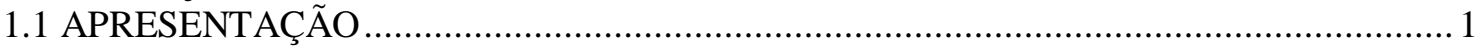

1.2 CONTEXTUALIZAÇÃO DO PROBLEMA

1.2.1 Contexto Histórico e Definições Conceituais ..................................................................... 1

1.2.2 Os Problemas Trazidos pela Soja Transgênica para a Cadeia Logística da Soja.................. 4

1.2.3 Medidas Mitigadoras de Risco de Contaminação nas Cadeias Logísticas ........................... 11

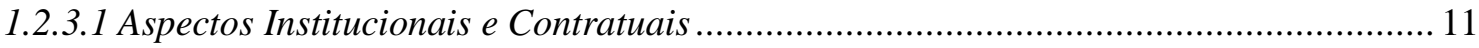

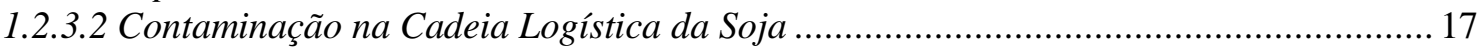

1.2.3.3 Custos de Segregação da Cadeia Logística da Soja ..................................................... 19

1.2.3.4 Estratégias de Segregação das Cadeias Logísticas de Grãos..........................................2 24

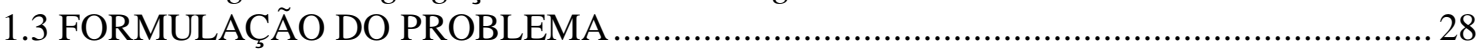

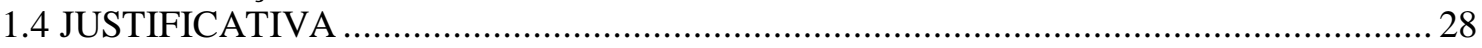

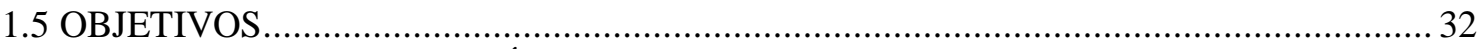

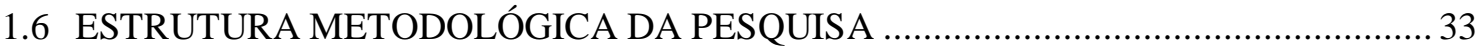

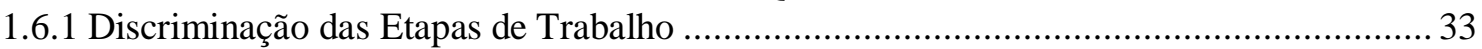

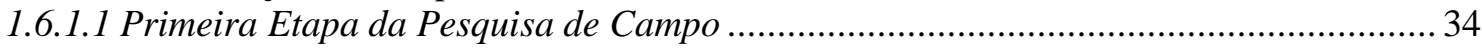

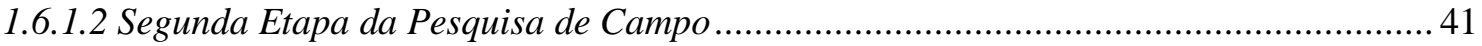

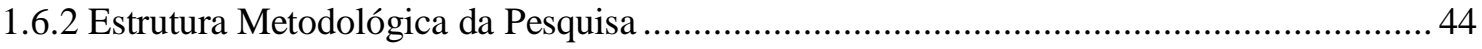

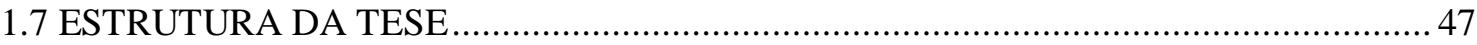

2. NOVA ECONOMIA INSTITUCIONAL E ECONOMIA DOS CUSTOS DE TRANSAÇÃO.. 49

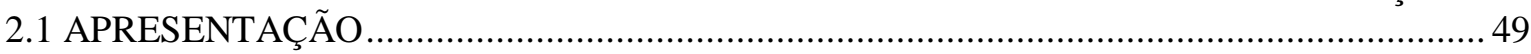

2.2 ASPECTOS INSTITUCIONAIS E A TEORIA DOS CONTRATOS ..............................50

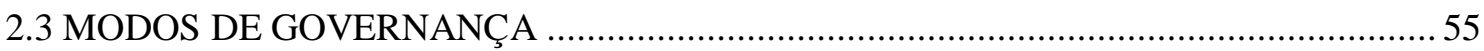

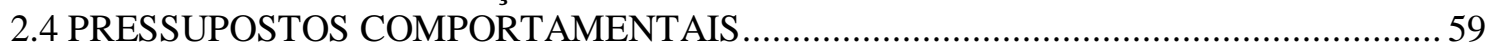

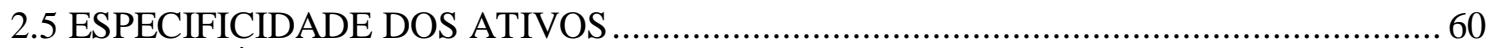

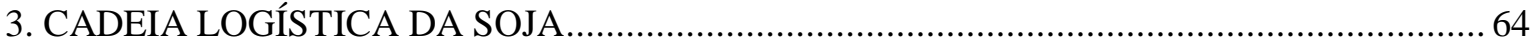

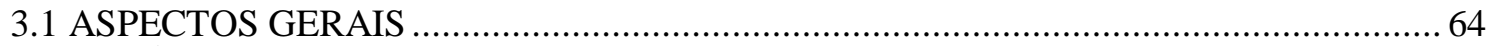

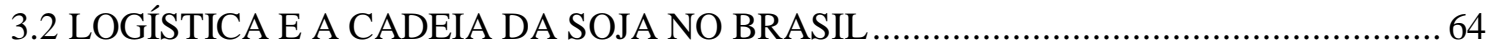

3.2.1 Agentes Envolvidos na Cadeia Logística da Soja no Brasil ..................................................69

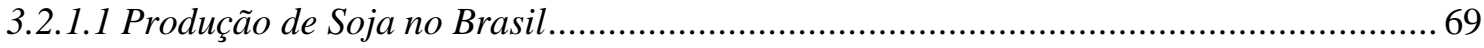

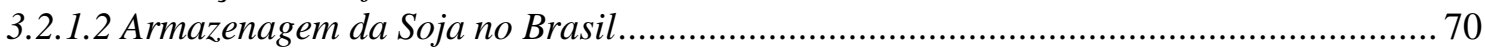

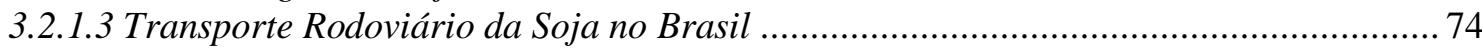

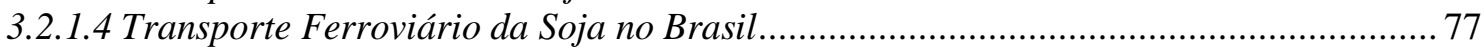

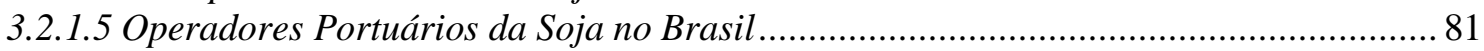

3.2.2 Movimentação, Modais Utilizados, e Principais Rotas da Soja no Brasil ........................ 88

4 PONTOS CRÍTICOS PARA O PROCESSO DE SEGREGAÇÃO E NÃO CONTAMINAÇÃO

DA SOJA CONVENCIONAL NA CADEIA LOGÍSTICA BRASILEIRA …........................... 92

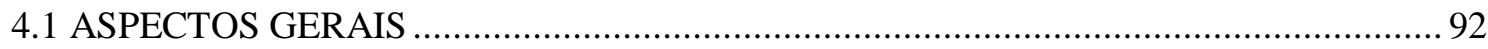

4.2 PRODUTORES QUE FAZEM A SEGREGAÇÃO DA SOJA ….................................... 93

4.2.1 Etapa 1: Processo de Compra de Insumos dos Produtores que Fazem a Segregação ......... 93

4.2.2 Etapa 2: Processo de Preparação do Solo dos Produtores que Fazem a Segregação .......... 97

4.2.3 Etapa 3: Processo de Plantio e Aplicação dos Defensivos dos Produtores que Fazem a

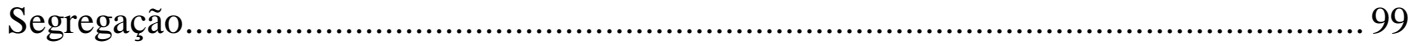

4.2.4 Etapa 4: Processo de Colheita dos Produtores que Fazem a Segregação ......................... 101

4.2.5 Etapa 5a: Processo de Armazenagem dos Produtores que Fazem a Segregação Utilizando o Mesmo Armazém / Etapa 5b: Processo de Armazenagem dos Produtores que Fazem a Segregação Utilizando Dois Armazéns .............................................................................. 103

4.2.6 Etapa 6: Processo de Venda/Expedição da Soja até o Porto Utilizando o Modal Rodoviário

4.2.7 Etapa 7: Processo de Venda/Expedição da Soja até o Porto Utilizando o Modal Ferroviário 
4.2.8 Etapa 8: Processo de Armazenagem do Trem ou Caminhão no Porto que faz a

Segregação da Soja

4.2.9 Etapa 9: Processo de Expedição da Soja do Armazenagem no Porto para o Navio

4.3. TRANSPORTADORES RODOVIÁRIOS

4.3.1 Informações Adicionais sobre Transporte, Armazenagem, Transbordo e Testes de

Transgenia na Cadeia Logística da Soja.

4.4 ARMAZENADORES/PROCESSADORES QUE FAZEM A SEGREGAÇÃO DA SOJA119

4.4.1 Prêmios e Contratos Feitos Pelos Armazenadores/processadores

4.4.2 Riscos de Contaminação e Estratégias de Segregação do Armazenador/processador da

Cadeia Logística da Soja

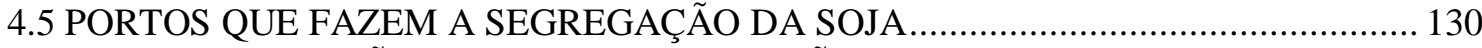

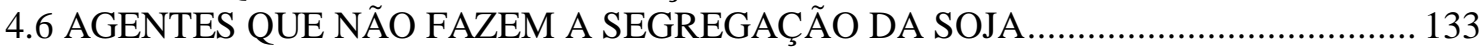

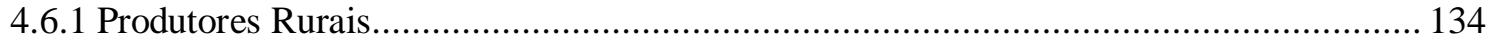

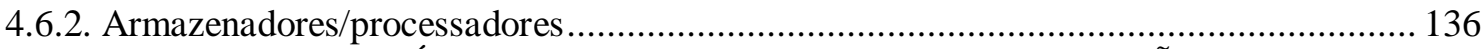

5 TEMPOS E CUSTOS LOGÍSTICOS ADICIONAIS PARA A SEGREGAÇÃO DA SOJA CONVENCIONAL E O PAPEL DOS CONTRATOS NA MITIGAÇÃO DOS RISCOS DE CONTAMINAÇÃO

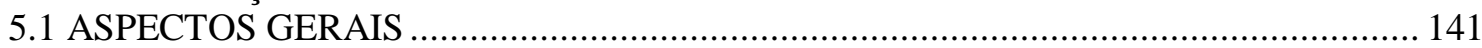

5.2 PONTOS CRÍTICOS E O PAPEL DOS CONTRATOS NA MITIGAÇÃO DOS RISCOS

DE CONTAMINAÇÃO

5.2.1 Estratégias e Parcerias Logísticas: o Papel dos Contratos como Mecanismos de

Incentivo/Controle para o Recebimento dos Prêmios pela Segregação da Soja ....

5.2.2 O Papel dos Armazenadores/processadores como Coordenador de Contratos na Cadeia Logística da Soja

5.3 TEMPOS E CUSTOS ADICIONAIS PARA FAZER A SEGREGAÇÃO DA SOJA

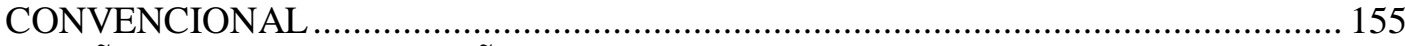

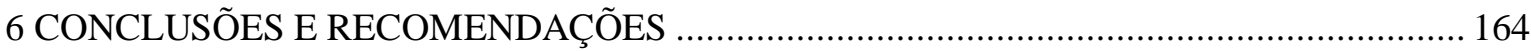

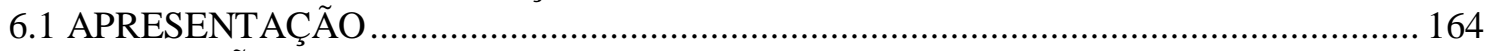

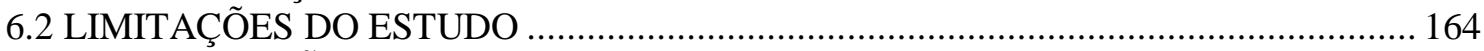

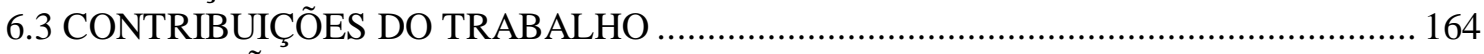

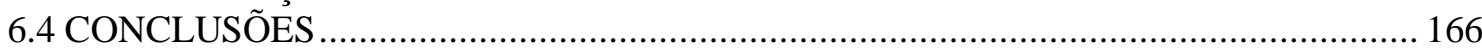

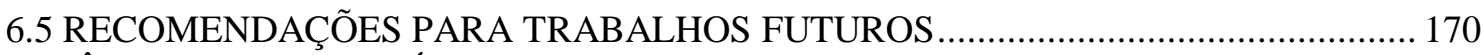

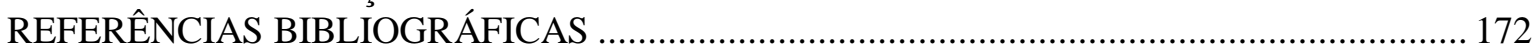




\section{LISTA DE TABELAS}

Tabela 1.1: Agentes entrevistados na primeira etapa da pesquisa

Tabela 1.2: Agentes entrevistados na segunda etapa da pesquisa

Tabela 3.1: Relação das atividades primárias e de suporte logístico com a cadeia logística da soja após o advento e a adoção dos transgênicos

Tabela 3.2: Evolução das exportações de farelo de soja por porto em 2014

Tabela 3.3: Destino das exportações de farelo de soja em 2014

Tabela 3.4: Evolução das exportações de óleo de soja por porto em 2014

Tabela 3.5: Destino das exportações de óleo de soja em 2014

Tabela 3.6: Evolução das exportações da soja em grãos por porto em 2014

Tabela 3.7: Destino das exportações da soja em grãos em 2014

Tabela 4.1: Principais mudanças na cadeia logística da soja sob a ótica do armazenador/processador

Tabela 4.2: Armazenadores/processadores que não fazem a segregação da soja

Tabela 5.1: Custos de produção e prêmio recebido pelos produtores

Tabela 5.2: Tempos e custos adicionais para os produtores fazerem a segregação da soja

Tabela 5.3: Tempos e custos adicionais para os armazenadores/processadores fazerem a segregação da soja

Tabela 5.4: Tempos e custos adicionais para os transportadores rodoviários fazerem a segregação da soja

Tabela 5.5: Tempos e custos adicionais para os transportadores ferroviários fazerem a segregação da soja

Tabela 5.6: Tempos e custos adicionais para os operadores portuários fazerem a segregação da soja

Tabela 5.7: Custos da segregação da cadeia logística da soja 


\section{LISTA DE FIGURAS}

Figura1.1: Processo de pagamento de royalties e recebimento de prêmios

Figura 1.2: Silos-bolsa de soja

Figura 1.3: Simbologias e significados dos fluxogramas utilizados no desenho dos processos logísticos da cadeia da soja

Figura 1.4: Percurso da soja da fazenda até o porto

Figura 1.5: Fluxo do percurso da soja da fazenda do produtor até o porto

Figura 1.6: Processo logístico da soja da fazenda do produtor até o porto

Figura 1.7: Esquema da metodologia empregada na pesquisa

Figura 2.1: A natureza "coaseana" da empresa originadora/processadora e suas transações

Figura 3.1: Atividades primárias no ciclo crítico de atividade logística

Figura 3.2: Relação entre atividades logísticas primárias e de apoio e o nível de serviço desejado.

Figura 3.3: Capacidade de armazenagem x produção do Brasil

Figura 3.4: Capacidade de armazenagem por estado x produção do Brasil

Figura 3.5: Malha viária utilizada no transporte da soja destinada a exportação

Figura 3.6: Atual sistema ferroviário brasileiro

Figura 3.7: Principais corredores ferroviários brasileiros

Figura 3.8: Portos públicos marítimos

Figura 3.9: Exportação mundial de soja em grãos safra 2013/2014

Figura 4.1: Etapa 1 - Processo de compra de insumos

Figura 4.2: Etapa 2 - Processo de preparação do solo para plantio

Figura 4.3: Etapa 3 - Processo de plantio e aplicação de defensivos

Figura 4.4: Etapa 4 - Processo de colheita

Figura 4.5: Etapa 5a - Processo de armazenagem utilizando o mesmo armazém do produtor

Figura 4.6: Etapa 5b - Processo de armazenagem utilizando dois armazéns do produtor

Figura 4.7: Etapa 6 - Processo de expedição da soja até o porto utilizando o modal rodoviário

Figura 4.8: Etapa 7 - Processo de expedição da soja até o porto utilizando o modal ferroviário

Figura 4.9: Etapa 8 - Processo de armazenagem do trem ou caminhão no porto que faz a segregação da soja 
Figura 4.10: Etapa 9 - Processo de expedição da soja do armazém no porto para o navio Figura 4.11: Estratégias de segregação utilizadas por armazenadores/processadores que utilizam duas unidades para receber os dois tipos de soja.

Figura 5.1: Processos logísticos com maiores possibilidades de contaminação na cadeia logística da soja. 


\section{LISTA DE ABREVIATURAS}

AAMA American Association of Medical Assistants

ABIOVE Associação Brasileira das Indústrias de Óleos Vegetais

ABRANGE Associação Brasileira de Produtores de Grãos não Geneticamente Modificados

ABRASEM Associação Brasileira de Sementes e Mudas

ABRATES Associação Brasileira de Tecnologia de Sementes.

ALL América Latina Logística

ANEC Associação Nacional dos Exportadores de Cereais

ANTT Agência Nacional de Transporte Terrestre

ANVISA Agência Nacional de Vigilância Sanitária

APPA Administração dos Portos de Paranaguá e Antonina

APROSOJA Associação dos Produtores de Soja e Milho do Estado de Mato Grosso

BSE Bovine Spongiform Encephalopathy

CCO Centro de Controle Operacional

CNA Confederação Nacional da Agricultura

CNT Confederação Nacional do Transporte

CONAB Companhia Nacional de Abastecimento

CSA Commodity System Approach

CTNBio Comissão Técnica Nacional de Biossegurança

DPI Direitos de Propriedade Intelectual

EAP Estrutura Analítica de Projeto

ECT Economia dos Custos de Transação

EUA Estados Unidos da América

GMO FREE Genetically Modified Organism Free

IBGE Instituto Brasileiro de Geografia e Estatística

IP Identidade Preservada 
MAPA Ministério da Agricultura Pecuária e Abastecimento

MERCOSUL Mercado Comum do Sul

NEI Teoria da Nova Economia Institucional

OGMs Organismos Geneticamente Modificados

PA Presença Adventícia

PCR Polymerase Chain Reaction

PIB Produto Interno Bruto

PNB Política Nacional de Biossegurança

RR Roundup Ready

SAG Sistema Agroindustrial

SEAPA Secretaria de Agricultura, Pecuária e Abastecimento

SEP/PR Secretaria de Portos da Presidência da República

SPI Sistema de Preservação de Identidade 


\section{INTRODUÇÃO}

\subsection{APRESENTAÇÃO}

Este capítulo tem o intuito de discorrer sobre o problema científico a ser estudado e as diretrizes metodológicas a serem utilizadas no trabalho.

São descritos os elementos estruturantes da pesquisa, quais sejam: a contextualização do problema, sua formulação científica, justificativas, objetivos, estrutura metodológica da pesquisa, plano de trabalho com o detalhamento das etapas e produtos esperados e, por fim, a forma em que se encontra organizado o documento.

Ademais, verificar-se-á que o trabalho contempla o referencial teórico que foi alicerce para as discussões finais e as propostas de melhoria da cadeia logística da soja, mostrando como esta se encontra atualmente, considerando as estratégias de segregação que podem ser adotadas para separar a soja convencional da transgênica.

\subsection{CONTEXTUALIZAÇÃO DO PROBLEMA}

\subsubsection{Contexto Histórico e Definições Conceituais}

Davis e Goldberg (1957, p.28) já chamavam a atenção para os problemas logísticos no âmbito do agronegócio em seu artigo seminal "A Concept of Agribusiness". Neste trabalho, os autores definiram o Agronegócio como sendo "a soma das operações de produção e distribuição de suprimentos agrícolas, das operações de produção nas unidades agrícolas, do armazenamento, processamento e distribuição dos produtos agrícolas e itens produzidos a partir deles".

A partir da década de 1930, com maior intensidade na de 1960 até a de 1980, o produtor rural passou, gradativamente, a ser um especialista, envolvido quase que exclusivamente com as operações de cultivo e criação de animais. Por sua vez, as funções de armazenar, processar e distribuir produtos agropecuários, bem como as de suprir insumos e fatores de produção, foram transferidas para organizações produtivas e de serviços nacionais e/ou 
internacionais fora da fazenda, impulsionando, com isso, ainda mais a indústria de base agrícola (VILARINHO, 2014), este fenômeno que ficou conhecido como apropriacionismo ${ }^{1}$.

O surgimento do agronegócio está relacionado com o processo de intensificação da atividade industrial, seja pelo surgimento de bens de capital e insumos agrícolas, seja pelo deslocamento das massas de trabalhadores do meio rural para o meio urbano, tal como se verificou nos principais países industrializados a partir da revolução verde. Especificamente no caso brasileiro, na década de 1950, iniciou-se o processo de modernização do campo, que se acentuou a partir da década de 1960, principalmente nas regiões Sul e Sudeste, expandindo-se para outras regiões, sobretudo a partir da década de 1970 (PLATA, 2001).

Em um primeiro momento, o processo de modernização da agricultura, base para a formação do agronegócio, esteve restrito pela capacidade de compra das exportações. No entanto, em meados da década de 1970, na medida em que este processo foi se intensificando com o desenvolvimento das indústrias voltadas especificamente para atender as demandas do setor agropecuário, (máquinas, equipamentos, defensivos, adubos, vacinas, rações e outros insumos), esse processo tornou-se autônomo, permitindo que a modernização da agricultura passasse a ser endógena e irreversível, no sentido de que uma regressão da base técnica implicaria também em uma regressão da produção agrícola (KAGEYAMA et.al., 1990, apud PLATA, 2001).

Na consolidação do agronegócio brasileiro, a dinâmica agropecuária passou a apresentar um perfil produtivo, baseado não somente na grande escala sustentada no uso de insumos e máquinas, mas também em sua conexão com a indústria. A agricultura transformou-se num ramo da produção semelhante à indústria, que compra insumos, produz matériasprimas e, depois, comercializa-as com outros ramos da produção. A agricultura passa,

\footnotetext{
${ }^{1} \mathrm{O}$ apropriacionismo refere-se a um movimento de apropriação industrial de frações do processo de produção agrícola, superando as restrições ambientais, de modo a possibilitar que as transnacionais tivessem um maior controle sobre os recursos necessários na produção e, por consequência, em relação ao resultado final. Esse processo foi evoluindo ao longo do tempo e cada vez mais etapas do processo produtivo eram apropriadas pela indústria. Esse processo visava à substituição de técnicas e processos naturais por técnicas industriais (GOODMAN et. al., 1990).
} 
dessa forma, a participar a montante e a jusante da malha de relações intersetoriais da economia, não existindo mais uma única dinâmica da agricultura em geral, mas várias dinâmicas com uma forma específica de ocupação produtiva do espaço geográfico, cada uma correspondente a um complexo agroindustrial, tal como descrito por Davis e Goldberg (1957).

O principal instrumento utilizado pelo Estado para promover a modernização da agricultura, e, portanto, o agronegócio, foi o crédito rural subsidiado, o qual estimulou a formação das cadeias agroindustriais por meio da utilização de insumos e práticas prédeterminadas pelo padrão vigente de modernização. A alocação desse crédito levou a uma acentuada diferenciação social e espacial que se manifestou numa elevada concentração fundiária e de renda. Ou seja, a política de crédito subsidiado privilegiou os grandes proprietários de terra e detentores de riqueza em geral, participantes das cadeias produtivas do agronegócio, enquanto discriminou os pequenos produtores (PLATA, 2001).

Entretanto, a política de crédito subsidiado praticada nas décadas de 1970 e 1980 foi substituída na década de 1990 por uma política de regulação da produção, por meio do mercado e por um conjunto de mudanças institucionais que permitiram aumentar a inserção do agronegócio brasileiro nas cadeias comerciais internacionais.

O agronegócio brasileiro passou por uma grande transformação nas décadas de 1970 e 1990, sendo impulsionado principalmente pelo desenvolvimento da Ciência e Tecnologia, proporcionando o domínio de regiões antes consideradas "inóspitas" para a agropecuária. Isso fez surgir a oferta de um grande número de produtos. O país passou, então, a ser considerado como aquele que dominou a "agricultura tropical", chamando a atenção de todos os nossos parceiros e competidores em nível mundial (LIMA, 2009).

No Brasil, essa abordagem sistêmica do Agronegócio foi utilizada explicitamente por Araújo et al. (1990), com a finalidade de levantar as dimensões básicas do agribusiness brasileiro. Os autores concluíram que esse agribusiness representava $46 \%$ dos gastos relativos ao consumo das famílias, o que equivalia a 32\% do PIB brasileiro em 1980. 
Atualmente, produtos oriundos do complexo de soja são itens importantes na pauta de exportação brasileira (VILARINHO, 2014). A evolução da composição do Complexo do Agronegócio confirma que as cadeias do agronegócio adicionam valor às matérias-primas agrícolas, em que o setor de armazenamento, processamento e distribuição final constituem o vetor de maior propulsão no valor da produção vendida ao consumidor, consolidado na forte rede de interligação entre a agricultura e a indústria.

Após a definição do conceito de agribusiness, os processos agroindustriais começaram a ser estudados através de duas vertentes metodológicas, a saber: a commodity system approach - CSA, desenvolvida por Goldberg em 1968 na escola americana, para estudar os sistemas produtivos do trigo, da soja e da laranja nos Estados Unidos; e a filière, também chamada de "cadeia de produção" ou "cadeias agroindustriais", desenvolvida pela escola industrial francesa também na década de 1960 (SCHNEIDER, et al., 2012).

Desde os conceitos de Análise de Fillière (cadeia produtiva), o agribusiness tem trabalhado com o foco voltado para uma abordagem econômica. A presente tese utilizou o conceito de cadeia logística, com uma abordagem de gestão.

Para não haver conflito entre os conceitos, utilizou-se na presente tese o conceito de Cadeia Logística da Soja, que, segundo Wieland e Wallenburg (2011) e Harland (1996), é a gestão do fluxo de mercadorias que inclui a movimentação e armazenagem de matériasprimas, estoque de produtos em processo e produtos acabados a partir do ponto de origem até o ponto de consumo, onde há redes interconectadas ou interligadas, havendo a necessidade da concepção, planejamento, execução, monitoramento e controle de todas as atividades para agregar valor ao produto final.

\subsubsection{Os Problemas Trazidos pela Soja Transgênica para a Cadeia Logística da Soja}

A liberação para plantio da soja transgênica no Brasil pela Comissão Técnica Nacional de Biossegurança $\left(\mathrm{CTNBio}^{2}\right.$ ), em 2005, trouxe transformações ao longo de toda a cadeia

\footnotetext{
${ }^{2}$ É uma instância colegiada multidisciplinar de caráter consultivo e deliberativo, integrante do Ministério da Ciência e Tecnologia, constituída para prestar apoio técnico e de assessoramento ao Governo Federal na formulação, atualização e implementação da Política Nacional de Biossegurança (PNB) de Organismos
} 
logística da soja, notadamente no transporte, no manuseio, na limpeza e na armazenagem do produto. Essa nova tecnologia também trouxe aumento nos custos de transação para todos os agentes envolvidos nessa cadeia, principalmente para aqueles que trabalham com as duas modalidades da soja, a convencional e a transgênica (LEITÃO, 2009).

A tecnologia dos transgênicos tem sido adotada pelos produtores como forma de buscar melhor desempenho e competitividade. Há evidências em algumas regiões no Brasil de que a adoção da nova tecnologia tem trazido bons resultados econômicos (LEITÃO, 2009; SILVEIRA; BORGES, 2005; SILVEIRA; RESENDE, 2010). Porém, os possíveis ganhos advindos da adoção da tecnologia podem ser dificultados pela necessidade de novas formas de organização dos ativos envolvidos na logística da cadeia da soja, emblematicamente no processo do transporte, manuseio e armazenagem do produto. Isso ocorreria principalmente na segregação ${ }^{3}$ entre soja convencional e transgênica.

A logística tem sido uma ferramenta importante para as cadeias produtivas na busca da melhoria de competitividade. Assim, as atividades logísticas que já eram importantes e que representavam valor considerável dos custos logísticos passam a assumir papel fundamental na cadeia da soja, principalmente com o surgimento de fatores tecnológicos impulsionados pela inovação, os quais podem influenciar toda a forma de organizar a logística de uma cadeia.

Importante ressaltar que a mudança trazida pela nova tecnologia dos transgênicos causou transformações na coordenação da cadeia logística da soja como um todo, além de gerar um problema de extrema gravidade, a contaminação da soja convencional pela transgênica. A partir disso, os produtores foram obrigados a ter mais cuidados ao longo de todos os estágios produtivos da soja, principalmente no transporte, no manuseio e na armazenagem, já que há fortes indícios de contaminação no desenvolvimento dessas atividades (LEITÃO, 2009; BRAGAGNOLO et al.,2007; CNA, 2008; ESPERANCINI et

Geneticamente Modificados (OGM) e seus derivados, bem como no estabelecimento de normas técnicas de segurança e de pareceres técnicos referentes à autorização para atividades que envolvam pesquisa e uso comercial de OGM e seus derivados, com base na avaliação de seu risco zoofitossanitário, à saúde humana e ao meio ambiente (MAPA, 2014).

\footnotetext{
${ }^{3}$ Segregação é o ato de separar ou isolar contato, de algo ou alguém. No caso estudado, é a separação da
} soja transgênica da convencional, para que não haja contaminação da última pela primeira. 

RESENDE, 2010).

Nesse sentido, a segregação é relevante, tendo em vista que existem dois mercados, o da soja convencional e o da transgênica. Além disso, devem-se considerar os prêmios ${ }^{4}$ pagos aos produtores que produzem soja convencional (LEITÃO, 2009).

Para Silveira e Resende (2010), a segregação é necessária, pois a manipulação de produtos diferenciados em estruturas de armazenamento, as quais estejam voltadas para commodities $^{5}$, é dificultada, o que requer maiores cuidados na recepção, fluxo e limpeza dos silos. Além disso, exige-se mão de obra específica para acompanhar o fluxo do produto diferenciado de menor escala. Para exemplificar melhor esse argumento, cita-se a recepção do milho wax $^{6}$, o qual é destinado para a indústria de alimentos para a produção de amidos especiais. Ao chegar às cooperativas, o milho recebe um tratamento especial em todo o fluxo de armazenagem, o que representa um maior custo de recepção, secagem e armazenamento. O maior custo é compensado pelo preço superior que esse produto recebe, que é em média de $48 \%$ em relação ao milho comum (SILVEIRA e RESENDE, 2010).

A Agência Nacional de Vigilância Sanitária (ANVISA) já exige a necessidade de instalações segregadas para a fabricação de medicamentos para uso veterinário e humano. A Agência relata que a produção de medicamentos que contêm ativos ou excipientes de uso exclusivo humano deve ocorrer em instalações segregadas para produtos de uso humano. Além disso, a ANVISA ressalta que as substâncias que são utilizadas tanto na terapêutica em humanos quanto em animais já possuem estudos científicos acerca da toxicidade em humanos, o que alivia o risco associado à possibilidade de contaminação cruzada de medicamentos (ANVISA, 2014).

\footnotetext{
${ }^{4}$ Refere-se ao valor pecuniário recebido pelos agentes que conseguem fazer a segregação do produto ao longo da cadeia logística da soja e entregá-la livre de transgênicos, ou seja, sem contaminação.

${ }^{5}$ Seu significado literal é "mercadoria", e é utilizado para designar bens e, às vezes, serviços para os quais existe procura sem atender à diferenciação de qualidade do produto no conjunto dos mercados. O termo também tem colocação entre vários fornecedores ou marcas, como é o caso da soja transgênica.

${ }^{6} \mathrm{O}$ milho waxy é uma especialidade, na qual sua matéria prima para a produção do amido de milho é rico em amilopectina, uma macromolécula ramificada de aproximadamente 1.400 resíduos de $\alpha$-glicose conectados, utilizado na indústria de suplementos alimentares.
} 
Outro empecilho que a contaminação pode trazer para os produtores rurais relaciona-se ao pagamento dos royalties, mesmo sem o uso dessa tecnologia. Isso pode ocorrer porque, involuntariamente, a soja pode ser contaminada, seja na compra da semente de soja convencional, soja esta que pode conter grãos transgênicos no momento do plantio e da colheita, caso não haja uma limpeza nas máquinas e equipamentos afins, seja nos portos. A falta de informação das pessoas que irão trabalhar com as duas sojas também pode ocasionar sua contaminação, caso os processos não sejam realizados com extremo cuidado.

São realizados testes de transgenia ao longo da cadeia para saber onde pode ter havido a contaminação. Este teste permite uma tolerância de até 5\% de grãos transgênicos para o pagamento dos royalties e $0,01 \%$ de grãos transgênicos para a garantia de soja livre de transgênicos, também conhecida como soja Genetically Modified Organism Free (GMO FREE), para a qual são pagos os prêmios (LEITÃO, 2009).

Ainda sobre o tema relacionado aos royalties, Lessa (2013) relata que a Monsanto ${ }^{7}$ adiou sua cobrança no Brasil, e "pretende continuar documentando e mantendo as informações comerciais relativas àqueles que usam a soja Round up Ready (RR) durante o período de adiamento da cobrança". A empresa busca corrigir o prazo de uma de suas patentes brasileiras para essa tecnologia até 2014.

O valor pago pelos royalties ainda é bastante questionado junto aos produtores e órgãos reguladores (CNA, 2008; LEITÃO, 2009). Caso seja acusada a contaminação, ao invés de o produtor pagar 2\% de royalties (valor cobrado pela Monsanto para o uso de sua tecnologia), ele pagará $3 \%$, como forma de punição por possíveis atos oportunistas, isso ocorre quando o produtor declara que a soja é convencional para não pagar os royalties. Por isso, existe a necessidade da segregação, ou de alguma forma de rastreabilidade ${ }^{8}$ para a garantia da preservação de identidade da soja convencional. Essa rastreabilidade pode

\footnotetext{
7 A Companhia Monsanto é uma indústria multinacional de agricultura e biotecnologia, detentora da patente da soja transgênica e líder mundial na produção do herbicidaglifosato, vendido sob a marca Round up Ready (RR), e de sementes geneticamente modificadas.

${ }^{8}$ A rastreabilidade é um conceito que surgiu devido à necessidade de saber em que local um produto se encontra na cadeia logística, sendo também muito usado em controle de qualidade. Dyer (1966) apud Juran et al.(1970, p. 280) afirma que rastreabilidade representa a capacidade de traçar o caminho da história, aplicação, uso e localização de uma mercadoria individual ou de um conjunto de características de mercadorias, através da impressão de números de identificação.
} 
ocorrer na separação de duas cadeias: a da soja convencional e a da soja transgênica. No entanto, esse isolamento das cadeias pode ser muito dispendioso, pois se for tomado o devido cuidado para a não contaminação em todas as etapas logísticas ao longo da cadeia não seria necessário essa separação.

A partir da exigência de uma fatia de consumidores, principalmente europeus, por produtos não geneticamente modificados, os gestores da cadeia da soja passaram a ter mais uma preocupação: a de separar a soja convencional da soja transgênica ou geneticamente modificada (SILVEIRA e RESENDE, 2010). Esse antagonismo aos Organismos Geneticamente Modificados (OGMs) desencadeou-se a partir de problemas ocorridos na Europa, e mais recentemente na Ásia, ocasionados pelas doenças denominadas de "vaca louca" (Bovine Spongiform Encephalopathy - BSE) e de gripe aviária. Esses acontecimentos acarretaram questionamentos em relação à segurança dos alimentos, fortalecendo uma posição contrária aos OGMs.

A primeira soja transgênica lançada comercialmente, obtida com a transformação genética de plantas através da engenharia genética, difere da soja convencional por possuir um gene que expressa resistência ao herbicida de ação total denominado de glifosato. A introdução desse gene facilitou o controle das ervas daninhas, e seu uso se generalizou em algumas regiões, quando, ao mesmo tempo, surgiram reações com críticas à segurança dessa nova tecnologia (SILVEIRA e RESENDE, 2010).

Outro fator que agrava ainda mais o problema é que os oponentes dos transgênicos veem a pressão das grandes empresas agroquímicas e $\operatorname{traders}^{9}$ para a liberação do comércio de OGMs no Brasil como uma estratégia de misturar irreversivelmente os mercados de cereais/oleaginosos convencionais e transgênicos, impossibilitando, dessa forma, opções de abastecimento, e, ao mesmo tempo, evitando os custos de implementar os sistemas de segregação e preservação de identidade. No curto prazo, declarações de associações de classe e evidências de forte lobby tendem a confirmar esta visão. Isso já é patente no Brasil, uma vez que mais de $90 \%$ da produção da soja brasileira já é feita a partir de sementes transgênicas (ABRASEM, 2014 e SAMORA, 2014).

9 Traders são empresas responsáveis pela comercialização da soja. Assim sendo, os armazenadores/processadores podem atuar como traders, como é o caso da LOUIS DREYFULLS, CARGILL, BUNGE, dentre outras, mas nem todos os armazenadores/processadores atuam como traders. Alguns fazem apenas o papel de recepção da soja em seus armazéns. 
Segundo Escobar (2014), o Brasil aparece no último relatório anual do Serviço Internacional para a Aquisição de Aplicações em Agrobiotecnologia como o segundo maior produtor de transgênicos no mundo, com 40,3 milhões de toneladas, à frente da Argentina (com 24,4 milhões) e atrás dos EUA (com 70,2 milhões). No caso da soja, 92\% da área plantada já é transgênica, e a perspectiva é que continue a crescer nos próximos 10 anos, chegando a 95\%, deixando um nicho de mercado de 5\% para a produção de grãos convencionais, os quais encontram mercados em países como Japão, Coréia, Suíça e Finlândia (ESCOBAR, 2014).

Além dos problemas econômicos gerados após o advento da soja transgênica, os produtos geneticamente modificados podem trazer outros problemas de extrema gravidade, notadamente aqueles relacionados à saúde humana.

Estudos feitos por Séralini et al. (2007) e Vendomois et al. (2009) mostram o potencial efeito negativo de transgênicos à saúde pública. Estes pesquisadores reavaliaram estatisticamente dados publicados anteriormente pela multinacional Monsanto, e declararam que a alimentação de ratos com milho transgênico, da variedade MON863, provocou toxicidade hepática e renal, bem como alterações no crescimento.

Estudos realizados por Heinemann (2009) mostraram que os animais alimentados com ingredientes transgênicos ficam diferentes daqueles cuja dieta é livre de OGMs. Segundo Heinemann (2009), existem provas convincentes de que animais alimentados com rações transgênicas podem reagir de uma forma específica, o que se revela através de respostas metabólicas, fisiológicas ou imunológicas.

Estudos mais recentes de Serálini et al. (2012) e Aliaga e Lust (2011) também têm demonstrado como os transgênicos podem trazer prejuízos para a saúde humana. Os estudos desses pesquisadores mostram que deve haver um cuidado muito grande na hora de decidir a respeito do consumo de transgênicos, já que eles podem trazer problemas irreversíveis para a saúde animal e possivelmente, humana.

A American Association of Medical Assistants (AAMA) concluiu que a relação entre os transgênicos e os efeitos negativos na saúde é mais do que uma mera coincidência, e que 
a ligação causa-efeito é confirmada em vários estudos em animais. Ainda segundo a AAMA (2014), os riscos para a saúde são sérios e incluem a infertilidade, a desregulação imunitária, o envelhecimento acelerado, a desregulação de genes associados à síntese do colesterol, à regulação da insulina, à comunicação celular, à síntese proteica e às alterações hepáticas, renais e gastrointestinais. Dados da AAMA (2014) mostram que os médicos provavelmente estão perto de encontrar esses efeitos em seres humanos.

Além dos problemas que os transgênicos podem causar para a saúde animal e humana, há pesquisas demonstrando que a produção de transgênicos também pode causar muitos efeitos negativos ao meio ambiente. Isso ocorre devido à sua interferência na diversidade e peculiaridades de cada ecossistema. Uma vez introduzida uma planta transgênica, seus efeitos são irreversíveis, pois com a ação dos agentes polinizadores sua propagação é incontrolável (SCHUSTER, 2013).

Vários estudos do GREENPEACE também têm demonstrado os mesmos efeitos negativos da utilização dos transgênicos no meio ambiente. Segundo esse órgão, a introdução de transgênicos na natureza expõe nossa biodiversidade a sérios riscos, como a perda ou a alteração do patrimônio genético de nossas plantas e sementes. Essa introdução torna ainda a agricultura e os agricultores reféns de poucas empresas que detêm a tecnologia (GREENPEACE, 2014).

Diante dessas questões, um dos problemas da "nova" cadeia logística da soja passa a ser a contaminação, havendo a necessidade da segregação do produto, pois além dos problemas relacionados ao meio ambiente e à saúde humana, há a possibilidade de recebimento de prêmios para os agentes que conseguem entregar a soja livre de transgênicos. Por outro lado, há a necessidade de investimentos em ativos para que se consiga fazer a separação, além da importância dos aspectos institucionais, em que os contratos podem ter passado a assumir papel fundamental dentro da cadeia logística da soja.

Sob essa perspectiva, torna-se importante saber se houve, e de quanto foi, o aumento dos custos da segregação ao longo da cadeia logística da soja, além de identificar as principais transformações que emergiram impulsionadas pela adoção da nova tecnologia. É também relevante identificar os problemas trazidos pela contaminação, os quais 
obrigam as empresas a tomar medidas mitigadoras de riscos para evitar mistura dos dois tipos de soja.

Relatados os principais problemas trazidos pela adoção da soja transgênica na cadeia logística da soja, o próximo tópico traz contribuições sobre as medidas mitigadoras de riscos de contaminação que estão sendo adotadas ao longo das cadeias logísticas.

\subsubsection{Medidas Mitigadoras de Risco de Contaminação nas Cadeias Logísticas}

Este item foi divido em quatro subitens para melhor apresentação e compreensão dos principais assuntos relacionados às medidas mitigadoras que estão sendo adotadas pelos agentes ao longo das cadeias logísticas, a saber: 1) Aspectos Institucionais e Contratuais; 2) Contaminação na Cadeia Logística da Soja; 3) Custos de Segregação da Cadeia Logística da Soja; e 4) Estratégias de Segregação das Cadeias Logísticas de Grãos.

\subsubsection{Aspectos Institucionais e Contratuais}

Na década passada, Wilkinson e Pessanha (2005) já chamavam a atenção para o fato de o Brasil não ter aproveitado o período da proibição do plantio para fortalecer sua capacidade de ofertar produtos diferenciados - convencionais ou orgânicos - aos mercados internacionais, principalmente para os europeus e japoneses. Os autores observaram ainda as dificuldades encontradas pelos estados membros da Federação para se constituírem como "áreas livres de transgênicos". Outro aspecto tratado por Wilkinson e Pessanha na obra supracitada é que a estratégia de manutenção e conquista de novos mercados não está sendo bem percebida atualmente pelos atores interessados, nesse caso, os armazenadores/processadores, os quais devem fazer a segregação da soja caso queiram entregar um produto livre de transgênicos para mercados que a demandarem.

O rápido processo de difusão da biotecnologia agrícola ocorre simultaneamente à necessidade de implementar um aparato regulatório, que implica custos ao longo da cadeia agroalimentar (OLIVEIRA, 2011). No caso da agricultura de grãos, isto tem ocasionado custos elevados associados à regulação. A emergência de um mercado consumidor mais exigente quanto à preservação da identidade de uma categoria de grãos e o crescimento das exportações de commodities agrícolas brasileiras apontam para a 
geração de impactos positivos, na forma de melhor remuneração para os produtos agrícolas de qualidade diferenciada. Todavia, tal tendência entra em choque com a estratégia brasileira dos últimos anos de exportar commodities, processo que expõe uma série de fragilidades logísticas do país (OLIVEIRA, 2011).

O processo de crescimento das exportações das commodities agrícolas brasileiras tem gerado impactos positivos, mas, ao mesmo tempo, revela uma série de deficiências logísticas do país. Tais deficiências, representadas pelas condições precárias das rodovias, pela baixa eficiência e falta de capacidade das ferrovias e pela desorganização e excesso de burocracia dos portos, tiveram como resultado o aumento das filas de caminhões nos principais portos de exportação, longas esperas de navios para a atracação e o não cumprimento dos prazos de entrega ao mercado internacional. Isso resultou no aumento dos custos e na redução da competitividade dos produtos brasileiros no exterior (FLEURY, 2014).

Segundo Martins et al. (2005), alguns fatos do mercado realçam a importância de se observar as variáveis institucionais que influenciam diretamente na segregação do produto, tais como:

a) o embarcador necessita da garantia de que sua mercadoria será entregue em tempo e em perfeitas condições;

b) no mercado de transporte de grãos, observa-se maior ocorrência de comportamentos oportunísticos. Sendo assim, os grandes demandantes, com frequência, preferem manter parte da frota própria (integração vertical) ou sob formas estritas de contratos para garantir que a soja livre de transgênicos (com atributos de qualidade especial) possa ser transportada sem que haja a contaminação do produto; e

c) a determinação do preço do frete depende da análise de custos, e incorpora outros atributos, tais como a localização geográfica, a carga de retorno e o valor da carga. O último atributo tem sido relevante no transporte da soja, uma vez que o valor da carga da soja convencional é superior ao valor da soja transgênica. 
Fuscaldi, Medeiros e Pantoja (2012) relataram que, no Brasil, para evitar ou minimizar a contaminação da soja convencional pela soja transgênica, há necessidade de leis para regulamentar sua coexistência. Além disso, foi constatado que a entrada de novas variedades de soja geneticamente modificada poderá aumentar a necessidade de implantação dessas regras. Segundo esses autores, na percepção de 63\% dos participantes de um estudo realizados por eles, o marco regulatório sobre os Organismos Geneticamente Modificados (OGMs) deveria incluir normas para todo o Sistema Agroindustrial (SAG) da soja, desde a produção da semente até o consumidor final, englobando toda a cadeia logística.

Com base nas informações levantadas por esses autores em pesquisa de campo, os seguintes pontos deveriam constar no instrumento legal: exigência de Unidades Beneficiadoras de Sementes (UBSs) independentes; distância entre plantios; exigência de barreiras de reflorestamento e barreiras naturais; critérios para limpeza dos maquinários de plantio, das colheitadeiras, dos caminhões, dos armazéns e dos secadores; histórico dos talhões de plantio e sua descontaminação de culturas transgênicas; padronização da metodologia de coleta e análise dos grãos e definição dos critérios das análises laboratoriais; e definição clara das responsabilidades de cada elo da cadeia e das penalidades em casos de contaminação e definição das responsabilidades do estado em casos de danos à saúde pública e ao meio ambiente (FUSCALDI, MEDEIROS; PANTOJA, 2012). Porém, isso ainda não é lei, e as empresas que fazem esses processos são aquelas que têm interesse em vender o produto diferenciado no mercado internacional para recebimento de prêmios.

Alguns estados já conseguem segregar as duas variedades de soja, como é o caso do Paraná. Por causa dessa precaução, que vem acontecendo desde 2005, o Paraná firmou contratos de venda de soja e farelo convencional com o mercado internacional, e parte dos custos está se revertendo em pagamentos diferenciados ao produtor paranaense na ordem de R\$2,00 por saca (TRANSPORTA BRASIL, 2013).

Segundo Malinarich (2010), há pagamento de prêmios para produtores de soja que conseguem fazer a segregação em silo-bolsas, pagando sempre um valor acima do preço de mercado, entre $\mathrm{R} \$ 1,00$ e $\mathrm{R} \$ 1,50$ por saca. 
Ao exigir a segregação da soja, a Administração dos Portos de Paranaguá e Antonina (APPA) garantiu o cumprimento de normas de identificação de cargas e de rotulagem dos produtos, o que permitiu o alinhamento do Paraná com a legislação internacional, bem como com o Protocolo de Cartagena. Esse protocolo prevê a identificação das cargas de navios que fazem as rotas internacionais. Sendo assim, a segregação da soja atende à Lei de Biossegurança $n^{\circ}$ 11.105, e o Estado do Paraná adequou-se à legislação federal com o intuito de zelar pelos procedimentos de rastreabilidade da soja convencional. Se não houvesse uma preocupação com a segregação, a soja provavelmente estaria misturada, e o Paraná poderia perder nichos de mercados internacionalmente valiosos, os quais exigem a compra da soja convencional para atender seus clientes mais exigentes (TRANSPORTA BRASIL, 2013).

Por causa dessa exigência, as cooperativas paranaenses também se adequaram e passaram a segregar a soja antes dos embarques. Com isso, o Paraná ganhou vantagens competitivas. Há comitivas francesas no Estado a fim de conferir a rastreabilidade da produção de soja convencional, desde as lavouras até o embarque no porto (TRANSPORTA BRASIL, 2013).

Outra vantagem do Paraná, a partir da exigência da segregação da soja no porto, foi o alinhamento do Estado com a Lei de Defesa do Consumidor, que no seu decreto 4.680, de 2003, determina a rotulagem dos alimentos elaborados a partir de grãos geneticamente modificados. O que motivou o Estado a tomar essa atitude foi a perspectiva da rejeição da produção paranaense por parte dos consumidores internacionais (TRANSPORTA BRASIL, 2013).

O uso da biotecnologia na diferenciação da soja por meio de atributos qualitativos requer o desenvolvimento de arranjos contratuais baseados em controles, isto é, subsistemas agroindustriais estritamente coordenados (ZYLBERSZTAJN; FARINA, 1999). Tais arranjos devem estar aptos a lidar com o suprimento de produtos com atributos de qualidade específicos e/ou garantir a apropriação dos investimentos envolvidos na inovação tecnológica (os quais seriam os custos da segregação do produto ao longo da cadeia logística). 
A inovação tecnológica da soja transgênica está relacionada ao princípio da inovação por subtração, trabalhada por Goulet e Vinck (2012), no qual um processo de inovação através de seus mecanismos de dissociação e distanciamento é baseado na diminuição de uma prática ou da subtração de um determinado artefato. Utilizando as ideias de Goulet e Vicnk (2012), pode-se afirmar que a soja transgênica é um exemplo de inovação por subtração, pois não está organizada em torno do "acréscimo", da adição, mas em torno da "subtração" de algo, que pode ser comprovado pela menor necessidade da aplicação de defensivos para combater as ervas daninhas (LEITÃO, 2009). Porém, concomitante a essa inovação, emergiu o problema da contaminação, que só não acontecerá se houver grande cuidado na segregação da soja. Logo, a contaminação ao longo da cadeia trará "acréscimos" de vários processos que serão necessários para fazer essa separação, como a necessidade da limpeza dos ativos, a capacitação de funcionários, a necessidade de contratos, dentre outros.

A "inovação por subtração" é frequentemente descrita por seus proponentes como uma resposta aos efeitos negativos da sociedade industrial, aos riscos ao meio ambiente e ao bem-estar produzido pelo progresso científico e técnico (GOULET; VINCK, 2012). Essa proposta parece ser totalmente contrária ao real propósito da soja transgênica, que traz em seu bojo como principal benefício a comodidade para os produtores que a utilizam, pois reduz a aplicação de defensivos agrícolas (LEITÂO, 2009), e não faz alarde dos reais problemas que ela pode causar para a saúde humana e ao meio ambiente.

A proliferação dos sistemas de biossegurança - incluindo mecanismos de comunicação ao consumidor, como rotulagem, preservação de identidade, processos de segregação e de rastreabilidade - acarreta complicações adicionais ao comércio internacional de produtos agrícolas, além de afetar o comércio de commodities agrícolas (SILVEIRA; OLIVEIRA, 2013). Segundo o estudo de Silveira e Oliveira (2013), existe a exigência de medidas adicionais, em que a identidade dos OGMs contidos nos carregamentos deve ser determinada por um Sistema de Preservação de Identidade (SPI), baseado em testes, incluindo uma lista de eventos presentes.

Sendo assim, para fazer uma total segregação da soja convencional, seria necessário um SPI em toda a cadeia logística. Por outro lado, a implementação deste sistema só seria viável se o prêmio recebido pelos agentes fosse compatível com os investimentos feitos. 
Entretanto, um mercado para produtos de identidade preservada (IP) surge quando os compradores estão dispostos a pagar mais por um produto, e quando produtores recebem incentivos econômicos (prêmios) (SILVEIRA e OLIVEIRA, 2013).

Como argumenta Sonka et al. (2000) apud Silveira e Oliveira (2013), uma série de forças, incluindo a biotecnologia, as inovações industriais de processamento e as preferências dos consumidores, têm induzido adaptações rápidas no mercado, criando mais oportunidades para a diferenciação e para o desenvolvimento de produtos com características específicas, como é o caso da soja livre de transgênicos.

Com a proliferação das culturas transgênicas, interessante questão contratual surgiu: a valorização econômica da soja convencional (GLITZ, 2009). O chamado "prêmio" ou "bônus" é a diferença (superior) paga por determinados países importadores aos produtores que lhes forneçam soja tradicional. Tal bonificação representaria verdadeiro incentivo à manutenção das culturas não "transgênicas" e ao desenvolvimento de mecanismos de segregação e rastreabilidade dos grãos. Uma nova complexidade instaurar-se-ia na comercialização da soja e de seus subprodutos, uma vez que ao lado das necessidades logísticas (colheita, transporte e armazenagem diferenciados), essa comercialização é indispensável na adoção de instrumentos de certificação (GLITZ, 2011).

A relevância econômica da discussão reside no tamanho do mercado brasileiro da soja e na diferença de preços apontada entre os dois tipos de grãos. Segundo informações da Associação Brasileira das Indústrias de Óleos Vegetais (ABIOVE), a complexa cadeia de contratos que envolve o sistema agroindustrial da soja movimentou o montante equivalente a US\$ 30.965 milhões em receitas com exportações ao longo do ano de 2013 (ABIOVE, 2014), sendo que nos últimos meses o "prêmio" por tonelada não transgênica variou entre US\$ 26,70 (janeiro) e US\$14,61 (abril) (GLITZ, 2011). Esse valor é significativo quando se leva em conta que o valor da saca de soja (cotação Chicago) variou entre US\$ 360,59 e US\$378,18 nos mesmos meses (GLITZ, 2011).

O mercado consumidor europeu parece, igualmente, dar indícios de valorização dos grãos tradicionais (GLITZ, 2009). Prova disso é a União Europeia, que estabelece requisitos de rastreabilidade e rotulagem de alimentos para consumo humano e animal produzidos a 
partir de OGMs. Os fabricantes de matéria-prima devem informar o uso de transgênicos em cada etapa do processo de produção e em todos os segmentos da cadeia produtiva (AGROLINK, 2013).

Através da rastreabilidade total, com identificação e garantia de origem, segregação e certificação, os consumidores têm maior segurança do alimento que irão consumir. Para ter essa garantia, os mercados compradores estão pagando em média $2 \%$ acima dos preços normais (AGROLINK, 2013).

No Oeste do Paraná, os grãos rastreados, segregados e certificados têm mercado garantido. Ou o mercado comprador passa a remunerar bem o produtor que se dedica ao cultivo da soja convencional ou correrá o risco de não ter mais o produto disponível (AGROLINK, 2013).

Conhecer as regras do jogo após o advento da soja transgênica é de fundamental importância para entender como são realizadas as transações entre os agentes dessa cadeia logística, bem como para saber se atualmente está havendo oportunismo por parte de algum ator nas atividades logísticas, já que alguns elos podem ter maior poder de fazer valer seus interesses. Também foi importante descobrir o papel dos contratos para uma melhor coordenação da cadeia logística, os quais influenciam diretamente seus custos e as formas de organizá-la.

\subsubsection{Contaminação na Cadeia Logística da Soja}

Vários estudos demonstram que há contaminação da soja ao longo de sua cadeia logística (LEITÃO, 2009; BRAGAGNOLO et al., 2007; CNA, 2008; ESPERANCINI et al., 2008; LEITÃO et al., 2007; MENEGATTI; BARROS, 2007; FUSCALDI, MEDEIROS; PANTOJA, 2012). Apesar disso, não se conhece com precisão em quais etapas logísticas há realmente riscos de contaminação.

Os estudos desses autores supracitados demonstram que o número de variedades de soja geneticamente modificadas disponíveis no mercado tende a aumentar, proporcionando novas opções para o produtor rural quanto à transgenia. Em contrapartida, os estudos revelam que há cada vez menos soja convencional sendo plantada no Brasil, o que torna a 
segregação ainda mais difícil, com maiores possibilidades de contaminação. Contudo, ressalta-se que a entrada de novas variedades de soja geneticamente modificadas poderá elevar a necessidade de implantação de regras de coexistência, já que existem mercados que ainda restringem este tipo de tecnologia e que o nível de contaminação tende a aumentar. Além disso, com a maior oferta de sementes transgênicas, mais produtores utilizarão a tecnologia.

A contaminação pode ocorrer em vários momentos: produção e tratamento da semente, plantio, plantas voluntárias, fluxo gênico, colheita, transporte, armazenagem e processamento. Em relação à produção de sementes, alguns estudos apontam que as UBSs seguem os padrões definidos pela legislação, nos quais existem linhas de produção diferenciadas para produtos convencionais e transgênicos. Ainda de acordo com esses padrões, as empresas produtoras de semente tomam cuidado para cumprir as normas de classificação estabelecidas pelo Ministério da Agricultura e Pecuária. Porém, os estudos enfatizam que, para muitos produtores, isso parece não ser tão patente, já que vários deles acusam a contaminação, principalmente por causa de sementes transgênicas estarem misturadas às convencionais (LEITÃO, 2009; BRAGAGNOLO et al., 2007; ESPERANCINI et al., 2008; LEITÃO et al., 2007; FUSCALDI, MEDEIROS; PANTOJA, 2012).

A pesquisa realizada por Fuscaldi, Medeiros e Pantoja (2012) constatou que há necessidade de normas para padronizar a movimentação do produto nos armazéns. Além disso, outra forma de minimizar a contaminação seria orientar produtores e empregados sobre os pontos frágeis do processo produtivo, investir em mão de obra e qualificação profissional, além de incentivar a adoção de apenas um dos sistemas de produção, visto que, no caso do Brasil, o uso da segregação é limitado devido à falta de infraestrutura e aos custos elevados.

Na colheita da safra existe também a possibilidade de contaminação da soja convencional pelo fato de muitos agricultores partilharem as máquinas colheitadeiras com vizinhos que plantam soja GM (LEITÃO, 2009; FUSCALDI, MEDEIROS; PANTOJA, 2012)

Sobre as informações que fazem parte de todo o processo logístico, Fuscaldi, Medeiros e Pantoja (2012) dizem que é necessário o desenvolvimento de mecanismos para a 
manutenção dos registros que guardem informações sobre o processo de cultivo, sobre a manipulação, a armazenagem, o transporte e a comercialização da soja geneticamente modificada.

Segundo Martins et al. (2005), com a tendência de elevação da linha de produtos e da frequência de entregas, novos atributos vêm sendo requeridos das atividades de armazenagem. Como resultado, novas tecnologias de processo e de informação têm sido incorporadas, sinalizando a importância estratégica da operação destas estruturas, emblematicamente com a adoção da tecnologia dos transgênicos, a qual pode trazer problemas de contaminação na armazenagem, caso não haja uma gestão extremamente eficiente ao longo do canal de expedição.

\subsubsection{Custos de Segregação da Cadeia Logística da Soja}

Há quase dez anos, Wilkinson e Pessanha (2005) diziam que as traders e as grandes empresas de primeiro processamento nas cadeias de commodities nos EUA já tinham iniciado a implementação de sistemas de segregação (exemplos disso seriam as exportações de qualidades específicas de soja e milho para o mercado japonês). Por isso, a transição para mercados agroalimentares de qualidade via segmentação das grandes cadeias de commodities seria uma tendência a ser acompanhada pelos países produtores de commodities como Brasil e Argentina, sob pena de perderem as posições competitivas até então conquistadas.

Segundo Silveira e Resende (2010), a segregação interna consiste nos trabalhos diferenciados de recepção, secagem e armazenamento, e foi incluída no custo da soja convencional, pois é ela que está sendo diferenciada para mercados específicos. Quanto menor o volume de um produto diferenciado, mais difícil e onerosa é sua separação e manipulação, como é o caso da soja convencional, que no Brasil é de apenas $10 \%$ do volume da produção total, e com uma tendência de diminuir ainda mais (ABRASEM, 2014; SAMORA, 2014).

Em pesquisa de campo realizada por Silveira e Resende (2010), foi constatado que para a realização da segregação interna da soja transgênica deve-se considerar um custo adicional de $\mathrm{R}$ \$ 6,90/ton (baseado em um câmbio de $\mathrm{R}$ \$2,30 para cada US\$ 1,00). 
Considerando ainda uma produtividade de $3 \mathrm{mil} \mathrm{kg} / \mathrm{ha}$ de soja transgênica, resulta em um custo de R\$ 20,70/ha. Ainda em relação ao custo de segregação interna, a pesquisa constatou que com $10 \%$ de produção de soja transgênica, prefere-se construir uma nova unidade de recepção para evitar misturas de grãos com a soja convencional. Nesse caso, o custo seria de $\mathrm{R} \$ 7,25 /$ ton. Da mesma forma, considerando uma produtividade de 3 mil $\mathrm{kg} / \mathrm{ha}$ pode-se chegar a um custo de $\mathrm{R} \$ 21,75 / \mathrm{ha}$. Para o estudo de Silveira e Resende (2010), foi considerado o menor valor de segregação interna ( $\mathrm{R} \$ 20,70 / \mathrm{ha})$.

Em entrevista realizada por Leitão (2009) em Mato Grosso, foi constatado que alguns armazenadores/processadores que faziam a segregação da soja tiveram que gastar mais de $\mathrm{R}$ \$ 2.000.000,00 na construção de novos armazéns exclusivos para a recepção da soja livre de transgênicos e, consequentemente, para fazer a segregação total do produto. Naquela época, os armazenadores/processadores informaram que o investimento (ativos específicos) seria compensatório pelo recebimento dos prêmios que as empresas estavam conseguindo na venda do produto para o mercado internacional.

A estrutura de custos para a identidade das culturas preservadas difere do mercado de commodities, pois inclui tanto os custos acrescidos da segregação quanto as despesas para mitigar os riscos específicos para os mercados de identidade preservada. Os riscos decorrem de um ou mais fatores de fixação de preços (prêmios de preço, qualidade e informação) e dos instrumentos para o cumprimento de protocolos internacionais, dentre os quais o Protocolo de Cartagena de Biossegurança. Esses aspectos são mais prevalentes em grãos de identidade preservada do que os grãos convencionais (BOÜET et al., 2010).

Os custos e os riscos têm implicações diretas não apenas nas relações comerciais, mas também na logística. Conforme Boüet et al. (2010), apesar dos avanços da biotecnologia, aspectos como infraestrutura e transporte continuam a ser fatores limitantes para as potencialidades da agricultura moderna.

Segundo Silveira e Oliveira (2013), quando se instala um sistema de identificação, há um custo de 3,6\% a mais na soja, porém, se não for feita a segregação da soja GMO FREE, há uma perda de 7,9\% das exportações para o Japão e de 4,8\% para a Europa, o que justificaria, em tese, a segregação das cadeias. 
A realização de testes no processo de escoamento leva a atrasos no processo de carga e descarga, devido aos procedimentos para a coleta de amostras do produto. Soma-se a isso o tempo necessário para se obter o resultado final da análise. No caso de preservação de identidade, além desses procedimentos, também seriam necessários cuidados adicionais com a armazenagem e transporte do produto, como maior rigor na limpeza das carretas, vagões e silos (SIMÕES, 2008 apud SILVEIRA; OLIVEIRA, 2013). Todos estes são custos adicionais com que a cadeia logística da soja começou a se deparar após o advento dos transgênicos.

Correa Jr. et al. (2001) destacam algumas variáveis que exercem influência sobre o estabelecimento do frete, a saber: distância percorrida; custos operacionais; possibilidade de obtenção de carga de retorno; agilidade dos processos de carga e descarga; sazonalidade da demanda por transporte; especificidade de carga transportada e do veículo utilizado; perdas e avarias; vias utilizadas; volume e valor do pedágio; rigor da fiscalização; prazo de entrega e alguns aspectos geográficos.

Remetendo-se ao caso da cadeia logística da soja, o custo com o transporte da soja convencional pode ter aumentado consideravelmente, principalmente no que diz respeito ao processo de carga e descarga, uma vez que para se transportar a soja convencional há a necessidade de se realizar os testes de transgenia, os quais trazem morosidade para este processo e aumentam os custos da segregação. Outro custo adicional seria a especificidade da carga transportada, já que para fazer o transporte da soja livre de transgênicos deve haver uma limpeza minuciosa em todos os caminhões para não ficar nenhum vestígio de soja transgênica remanescente.

Assim, os custos parecem vir, principalmente, a partir do próprio processo de produção (ou seja, desde o plantio). Argumenta-se que um custo maior para manipuladores vem de uma perda da flexibilidade, devido à necessidade de dedicar equipamento a um dos dois canais (um para tratamento de OGMs e um para não OGMs). Os níveis de tolerância são um elemento fundamental dos custos de segregação. Aqueles de tolerância zero podem ser impossíveis de obtenção sem grandes custos organizacionais e econômicos (BULLOCK; DESQUILBET, 2002). 
Barone e Ojima (2008) também argumentaram que a característica fundamental do processo de produção de commodities para exportação é o ganho em volume, e a redução de custos nas etapas de transporte e armazenamento é uma condição básica de competitividade. Para eles, a realização da segregação e rastreabilidade de grãos geneticamente modificados implicaria em maior ineficiência do transporte, aumentando seus custos.

Em uma primeira análise, as perdas em valores absolutos da soja negociada não parecem ser tão expressivas. Porém, quando são analisadas as perdas monetárias, considerando as despesas com os testes e armazenagem (US\$ 1,1 bilhões) e a redução do comércio internacional (US\$ 442 milhões), as perdas chegam a US\$ 1,54 bilhões (SILVEIRA; OLIVEIRA, 2013). Este montante representa 13,5\% das divisas geradas pelas exportações de soja em grão para o Brasil em 2009, totalizando US\$ 11,3 bilhões (SILVEIRA; OLIVEIRA, 2013).

Ao produtor, no entanto, resta a questão dos custos assumidos com a infraestrutura necessária para garantir a distinção entre os respectivos grãos. A responsabilidade pelo manejo, neste sentido, recai sobre ele.

Além da perda da bonificação, o contágio pode representar, eventualmente, inadimplemento contratual (e, portanto, dever de pagamento de cláusula penal), necessidade de pagamento de royalties para a detentora da patente e responsabilidade pelos demais danos causados à cadeia logística (GLITZ, 2011).

A Figura 1.1 traz um esquema ilustrativo do pagamento dos royalties e recebimento dos prêmios para melhor entendimento e compressão das etapas que compõem essa problemática. Importante ressaltar a complexidade dos processos que os agentes da cadeia logística passaram a ter de lidar após o advento e a difusão dos transgênicos, o que antes não era necessário. 


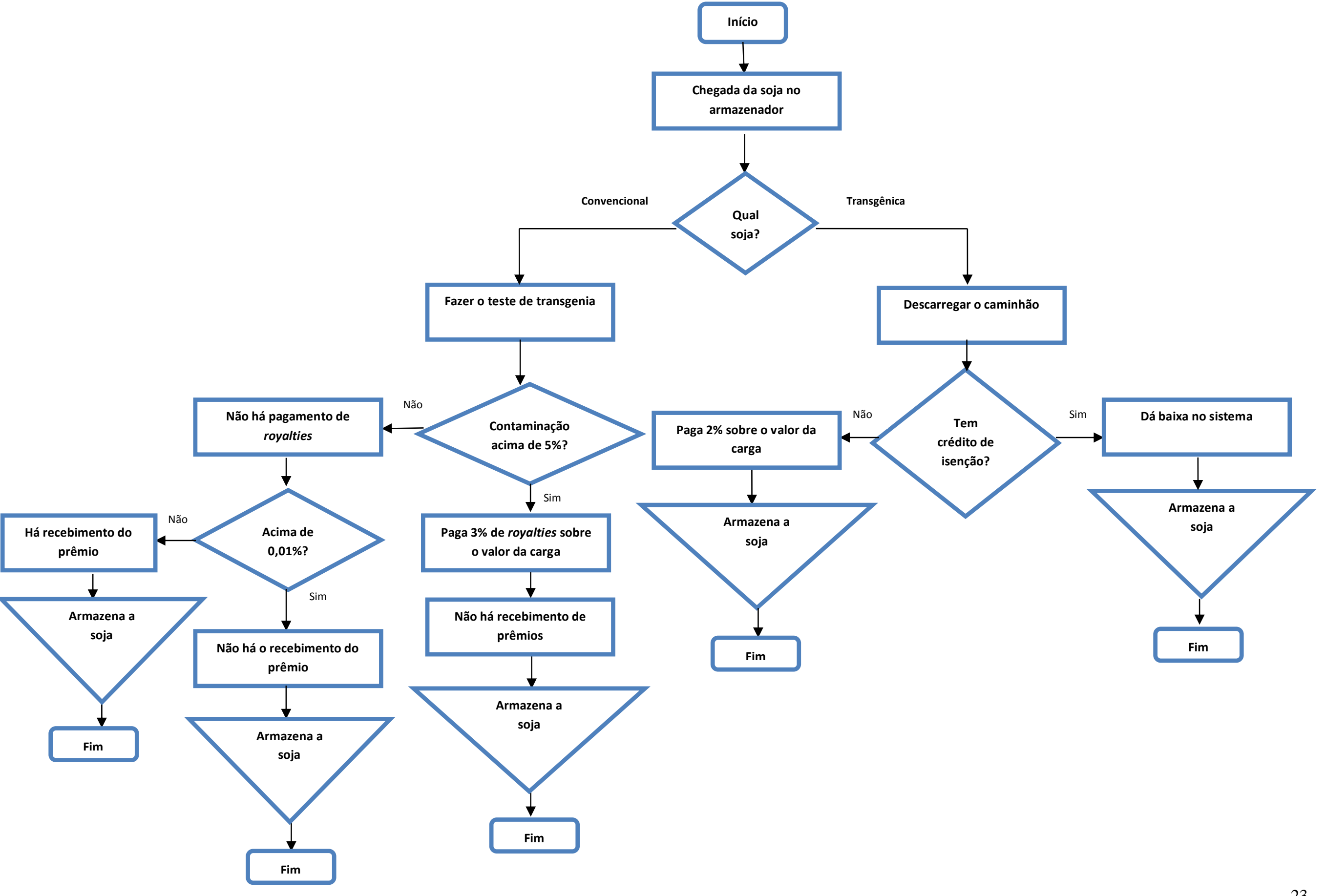


Figura1.1: Processo de pagamento de royalties e recebimento de prêmios

Fonte: Elaborado pelo autor (2014)

O próximo tópico mostra algumas estratégias utilizadas pelos agentes como forma de fazer a segregação de grãos ao longo das cadeias logísticas. Importante ressaltar que foi feita uma tentativa para o levantamento de como é realizada a segregação dos alimentos funcionais ${ }^{10}$ e nutracêuticos ${ }^{11}$, por serem alimentos com demandas específicas no mercado, assim como a soja livre de transgênicos, e que provavelmente seja necessário sua segregação ao longo da cadeia para garantir a oferta. Não se encontrou, todavia, literatura especializada disponível sobre esse tema.

\subsubsection{Estratégias de Segregação das Cadeias Logísticas de Grãos}

Barone e Ojima (2008) já chamavam a atenção para a importância da segregação dos grãos geneticamente modificados, e para o impacto que isso traria para a logística da soja brasileira. Para esses dois autores, a expansão da área plantada com grãos geneticamente modificados pode desempenhar forte pressão no sistema de movimentação de grãos. Com um mercado consumidor mais exigente quanto à preservação da identidade de uma categoria de grãos, os desafios à logística tornam-se mais relevantes.

Barone e Ojima (2008) fizeram um estudo com um modelo de equilíbrio espacial desenvolvido para a otimização da movimentação da soja, utilizando dados de produção, capacidade de processamento, preço nas diferentes regiões e elasticidade-preço de oferta e demanda. A solução sugerida pelos autores para essa problemática foi uma indicação das principais rotas para o escoamento da safra, detalhando, inclusive, o impacto da segregação no que tange aos testes para a identificação de grãos geneticamente

\footnotetext{
10 Caracterizam-se por oferecer vários benefícios à saúde, além do valor nutritivo inerente à sua composição química, podendo desempenhar um papel potencialmente benéfico na redução do risco de doenças crônicas degenerativas (diabetes, hipertensão, câncer, etc.) (ANVISA, 2014).

${ }^{11}$ Alimento ou parte de um alimento que proporciona benefícios médicos e de saúde, incluindo a prevenção e/ou tratamento da doença. Tais produtos podem abranger desde os nutrientes isolados, suplementos dietéticos na forma de cápsulas e dietas até os produtos beneficamente projetados, produtos herbais e alimentos processados tais como cereais, sopas e bebidas. (ANVISA, 2014). Substâncias que podem ser consideradas um alimento ou parte de um alimento, proporciona benefícios tanto para manutenção da saúde como também terapêuticos, incluindo prevenção e tratamento de doenças (MEDEIROS, et. al., 2009)
} 
modificados. O volume total comercializado no cenário em que houve incidência de testes sofreu uma redução de 6,36\%. À medida que aumentava o número de testes ao longo do trajeto, maior era o acréscimo no custo do transporte. Isso levava a uma redução da produção, em virtude do aumento dos custos. Outras consequências desse acréscimo foram a diminuição da comercialização, especialmente com o mercado externo, e a reflexão na perda de competitividade da soja brasileira (BARONE; OJIMA, 2008).

Wilson e Dahl (2003) estudaram os custos logísticos para a preservação de identidade da cadeia do trigo geneticamente modificado. Segundo eles, o desenvolvimento de culturas geneticamente modificadas desafia as funções do sistema de comercialização de grãos. No estudo, os autores utilizaram um modelo de otimização estocástica para determinar estratégias de testes ideais. $\mathrm{O}$ modelo escolhe a estratégia de testes ideal que maximiza a utilidade de custos adicionais do sistema, devido a testes e rejeição, e permite a estimativa do prêmio de risco exigido para os vendedores para realizar dupla comercialização de OGMs e GMO FREE, através de um sistema de PI. Elementos de custo incluem testes, rejeição e prêmio de risco, os quais foram estimados para uma cadeia de exportação de grãos. O modelo incluiu elementos de custos e riscos na cadeia de comercialização, incluindo a de fungibilidade acidental em todas as etapas da cadeia de comercialização, a declaração da variedade utilizada, e o fato de o produtor dizer a verdade na precisão dos testes tecnológicos.

Através deste estudo, Wilson e Dahl (2003) mostraram que há grande dificuldade de segregação ao longo das cadeias logísticas para quase todos os produtos que devem ser segregados, inclusive para a cadeia logística da soja.

Para Schleht, Wilson e Dahl (2004), segregações especiais que proporcionam qualidades únicas de produtos de uso específicos estão sendo demandadas pelos compradores. Em estudos de segregação da cadeia de trigo, os autores afirmam que como os usuários de trigo se tornam cada dia mais específicos e exigentes no que se refere à qualidade do produto, o número de segregações de qualidade aumenta, aumentando também, consideravelmente, os custos logísticos para operar a segregação.

Pesquisas realizadas por esses autores demonstraram que os custos logísticos aumentam à medida que mais segregações são necessárias. Ademais, as incertezas durante o processo 
de segregação também aumentaram consideravelmente os custos logísticos (SCHLECHT, WILSON e DAHL, 2004).

Coleno (2008) realizou um estudo de simulação e avaliação de estratégias de segregação de transgênicos e não transgênicos entre os comerciantes europeus de cereais. Segundo ele, considerando-se as regulamentações europeias, um produto precisa ser rotulado como contendo transgênico, quando a presença acidental de material geneticamente modifiado ultrapassa $0,9 \%$. Durante a colheita, as culturas de diversas áreas são combinadas para encher um silo; sendo assim, Coleno identificou três estratégias de gestão para evitar o risco de mistura de culturas OGMs e GMO FREE baseadas em estudos de casos em várias regiões da França:

(i) fazer a separação de OGMs e GMO FREE nos silos e nas zonas de produção;

(ii) especificar o tempo de entrega de culturas OGMs e GMO FREE em silos; e

(iii) usar as regras de gestão local em cada etapa da cadeia de abastecimento.

A fim de avaliar estas estratégias e compará-las com a gestão da cadeia de suprimentos real, foi proposto um modelo de gestão da cadeia de suprimentos. A alocação de silos específicos para culturas OGMs e GMO FREE permite que toda a produção não transgênica possa ser segregada, no entanto, com um aumento de $700 \%$ no custo de armazenagem. A especificação do tempo de culturas OGMs e GMO FREE colhidas permite que todas as culturas GMO FREE possam ser segregadas, sem qualquer aumento de custos. Porém, é necessária uma gestão muito bem realizada para que as duas sojas não sejam colhidas na mesma época.

Malinarich (2010) traz algumas inovações no âmbito do agronegócio, adotadas como medidas de segregação de grãos no processo de armazenagem. O autor relata que há nichos de mercado denominados "mercados de qualidade", os quais necessitam de mercadorias diferenciadas, emblematicamente quando há restrições de comercialização de transgênicos.

Uma forma alternativa para fazer a segregação é colher o produto e deixá-lo no silo-bolsa no talhão, conforme mostra a Figura 1.2. Fazendo isso, far-se-ia a segregação da soja nos armazéns, uma vez que não seria necessária a construção de um novo silo só para colocar 
um tipo específico de soja, a transgênica ou a convencional. Essa poderia ser uma saída para a redução dos custos em ativos com maior especificidade, como é o caso da construção de um silo ou armazém exclusivo para receber a soja convencional como forma de segregação.

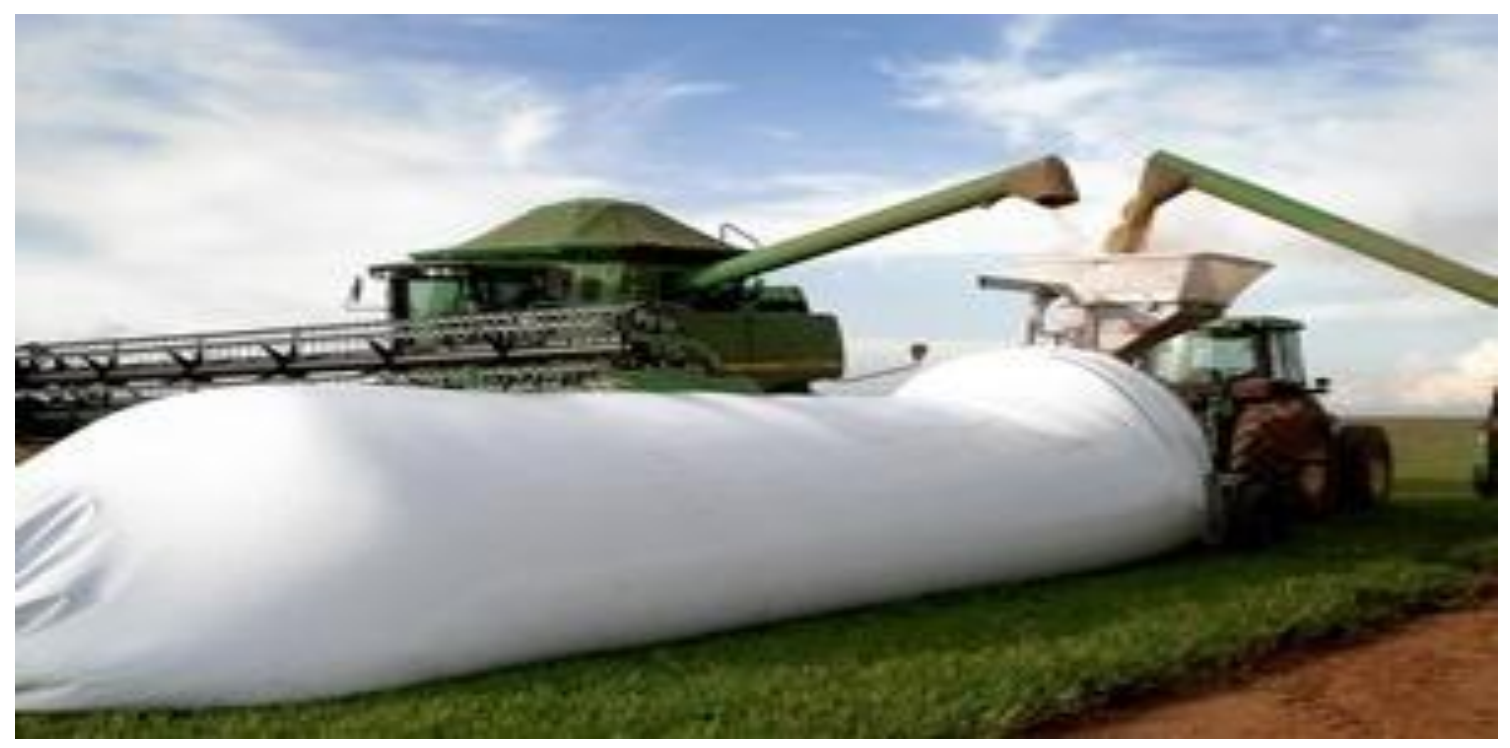

Figura 1.2: Silos-bolsa de soja

Fonte: Malinarich (2010)

Ainda de acordo com Malinarich (2010), a técnica de armazenamento de grãos em sacos plásticos foi amplamente difundida e bem sucedida na última década, não só no MERCOSUL, mas também em lugares diversos como Austrália, Ucrânia, Canadá, África do Sul e Sudão. Isso permitiu uma adaptação às necessidades dos produtores e armazéns industriais para resolver alguns problemas que surgem na complexa cadeia de processos, principalmente no que tange à segregação do produto. Essa poderia ser uma saída para os produtores que não têm armazéns em suas fazendas para fazer a segregação do produto.

No caso da soja, o isolamento espacial de algumas dezenas de metros, acompanhado por uma borda de contenção de soja convencional em volta da parcela transgênica, deveria diminuir o risco de contaminação por polinização a um valor próximo de zero. Em Fernandes et al. (2009), esse processo é chamado de bordas de contenção.

Contudo, há outros processos logísticos, como a possibilidade de mistura de sementes durante a colheita, o transporte, o armazenamento e o processamento, problemas estes não relacionados à borda de contenção. Nesse caso, o risco zero não existe, haja vista os 
outros problemas logísticos envolvidos nessa etapa, como a utilização de máquinas agrícolas contaminadas, dentre outros (FERNANDES et al., 2009).

Estudos feitos por Schuster (2013) mostram que o distanciamento de 8 metros é o bastante. Entretanto, quanto maior for a distância, menor será o risco de contaminação. Schuster afirma ainda que a principal causa de contaminação por polinização cruzada é a mistura de sementes em razão da limpeza inadequada de equipamentos, e não do fluxo de pólen (SCHUSTER, 2013).

\subsection{FORMULAÇÃO DO PROBLEMA}

Contextualizado o tema, o problema trabalhado nesta Tese foi: Quais os cuidados, procedimentos e custos adicionais necessários para fazer a segregação da soja convencional (GMO FREE) ao longo da cadeia logística? E como garantir a oferta de um produto livre de transgênicos?

\subsection{JUSTIFICATIVA}

A escolha da cadeia logística da soja como objeto de estudo está diretamente relacionada com a importância desse produto para a balança comercial ${ }^{12}$ brasileira. A contaminação da soja, fato que passou a exigir cuidados e procedimentos, e os custos adicionais que não eram necessários antes da adoção dos transgênicos também têm papel determinante na escolha desse objeto. O Brasil já é bastante competitivo na produção de soja para o mundo, contudo, caso consiga fazer a segregação e ofertar um produto diferenciado para o mercado internacional, poderá ter uma vantagem competitiva sobre os demais concorrentes, pois estes não tem conseguido êxito na separação do produto.

A aparente possibilidade de convivência dos mercados de soja transgênica e convencional esbarra em dificuldades para países produtores e exportadores. Essas dificuldades estão relacionadas com as modificações necessárias ao longo de toda a cadeia logística, de forma a garantir o produto convencional livre de grãos transgênicos (MENDEZ DEL

\footnotetext{
${ }^{12}$ O complexo de soja (grão, farelo e óleo) é o principal gerador de divisas cambiais do Brasil, com negociações anuais que ultrapassam US\$ 20 bilhões. Em 2019, a produção nacional deve representar 40\% do comércio mundial do grão e $73 \%$ do óleo de soja (MAPA, 2014).
} 
VILLAR et al.,2007). Tais modificações dizem respeito não apenas a aspectos técnicos relacionados com a segregação, mas também às formas de governar as transações entre os agentes. Essas formas de governar tiveram suas características afetadas pela elevação do nível de especificidade dos ativos envolvidos e do maior controle/cuidado que deve existir no transporte e armazenagem, haja vista a possibilidade de contaminação ao longo de sua cadeia logística.

Essa problemática agrava-se ainda mais pela ausência de um marco jurídico claro para a pesquisa e a comercialização de produtos geneticamente modificados e de seus derivados; esta, mantida até março de 2005, quando foi finalmente aprovada pelo Congresso a Lei de Biossegurança. A aprovação da lei teve como um de seus efeitos indesejáveis a insuficiência de avaliações cientificamente delineadas de impactos socioeconômicos e ambientais.

A contaminação transgênica tem impacto econômico negativo nos setores da economia que escolhem permanecer livres deste tipo de produto. Como a maioria dos países não tem um sistema de responsabilização pelos organismos geneticamente modificados, os custos para se evitar a contaminação transgênica acabam sendo bancados pelos contaminados, e não pelo contaminador. Esse fenômeno se traduz em uma externalidade negativa, a qual prejudica os agentes e setores que desejam permanecer no modo convencional e orgânico de plantio (FUSCALDI, MEDEIROS; PANTOJA, 2012). Isso demonstra a importância de se ter um marco regulatório bem delineado para que haja punição àqueles que realmente contaminarem a soja ao longo da cadeia. Este marco pode ser viabilizado através da formalização de contratos entre os agentes, o que motivaria a não contaminação do produto.

Nesse sentido, a atividade de segregação é necessária para permitir a convivência dos dois mercados, e tem o custo apontado como empecilho tanto pelos produtores rurais quanto pelos armazenadores/processadores (WILKINSON; PESSANHA, 2005). O referido custo diz respeito não apenas às modificações técnicas nas fases de produção, transporte e armazenamento, mas também aos custos de transação a que estão sujeitos (LEITÃO, 2009). 
Segundo Abrange (2014), há uma crescente rejeição aos transgênicos, e existe um aumento da demanda por grãos convencionais, além do espaço para os produtos não geneticamente modificados brasileiros nos mercados internos e externos ser enorme. Mais de 230 regiões na União Europeia, aproximadamente 4.200 municípios, além de associações e produtores, declararam-se "GMO FREE", comprometendo-se a não permitir o uso de organismos geneticamente modificados na agricultura em seus territórios. A Europa, assim como a Austrália, a Coréia e o Japão, são mercado abertos aos grãos brasileiros que não foram modificados geneticamente. As empresas, no entanto, têm tido dificuldades no processo de segregação entre os grãos transgênicos e convencionais (ABRANGE, 2014).

A preferência para a aquisição de soja livre de transgênicos cai naturalmente sobre o Brasil, país no qual o abastecimento com soja convencional ainda é possível. Frente à perda de mercados, porém, os armazenadores/processadores norte-americanos começam a experimentar sistemas de segregação e oferecem prêmios para grãos convencionais (WILKINSON; PESSANHA, 2005 e 2013); fato que também tem acontecido no Brasil (LEITÃO, 2009).

A Comissão Europeia (2013) afirma que o mercado de produtos obtidos através de sistemas de preservação de identidade ${ }^{13}$ tem expectativa de crescimento tanto em número quanto em nichos de mercado, com ou sem a presença de OGMs. Nos EUA, é estimada uma participação de $10 \%$ na produção agrícola com sistemas de identidade preservada e espera-se um incremento de $30 \%$ em dez anos.

Segundo Silveira e Resende (2010), ofertar um produto diferenciado pode exercer influências positivas no mercado consumidor. Estabelecido o produto diferenciado e definido o consumidor, deve-se atentar para a efetivação de contratos de compra e venda.

\footnotetext{
${ }^{13}$ A preservação de identidade é uma forma de sinalizar a diferenciação de um produto de qualidade superior que implica aumento nos custos, os quais permeiam todas as fases da cadeia. Estes custos são identificáveis e têm forte relação com as características das transações e com os atributos do produto que se deseja segregar. Os custos adicionais de produção, distribuição e processamento vão depender, basicamente, das seguintes características: tolerância à contaminação, aspectos agronômicos, especificidade temporal e quantidade de produtos derivados. As estratégias de incentivo e monitoramento são fundamentais também para o sucesso do sistema de PI (SOUSA, 2001). Grãos com identidade preservada são grãos com características distintas, identificadas e segregadas desde o plantio até o processamento. A preservação da identidade é um processo que envolve infraestrutura própria para o manuseio, além de documentação e certificação providas por instituições independentes em cada estágio da cadeia (ASA, 2002).
} 
Essa formalização diminui riscos característicos de mercados ainda inconsistentes (MARQUES; AGUIAR, 1993).

Pesquisas realizadas por Silveira e Resende (2010) mostram que o governo do Estado do Paraná segue uma linha de precaução, tentando preservar o seu mercado de soja convencional, alegando a possibilidade de esta ser contaminada pela soja transgênica, o que dificultaria a exportação para mercados exigentes. De fato, para a distinção de produtos agroalimentares que atendam a mercados segmentados, é necessária a utilização de ferramentas para a preservação da identidade, garantindo, dessa forma, as suas qualidades.

Estudos têm apontado que a soja convencional já é um nicho de mercado a ser explorado pelo Brasil, onde a soja não modificada se caracteriza como um mercado especial (ABRATES, 2014). Os produtos de soja brasileiros possuem alto teor de proteína e padrão de qualidade, o que permite sua entrada na União Europeia e no Japão. No entanto, estes mercados são altamente exigentes e resistentes ao consumo de transgênicos (ABRATES, 2014).

A questão da possibilidade de convivência dos mercados de grãos convencionais e transgênicos também passa a sofrer a influência da emergência dos novos mercados representados pela transformação de commodities em especialidades ${ }^{14}$. Tais mercados são voltados para grãos com qualidades específicas, os quais precisam passar pelo mesmo problema de preservação de identidade - exigências de segregação. Nesse sentido, a transição para mercados agroalimentares de qualidade, via segmentação das grandes cadeias de commodities, seria uma tendência a ser acompanhada pelos países produtores de commodities, como o Brasil e a Argentina, sob pena de perderem as posições competitivas até aqui conquistadas (MEDEIROS et al., 2007).

\footnotetext{
${ }^{14}$ Diferentemente de uma commoditie, a especialidade é um produto diferenciado, que o mercado consumidor está disposto a pagar a mais para tê-lo, como é o caso da soja livre de transgênicos. Segundo Souza (2012), as especialidades geralmente são produzidas em pequena escala, voltadas para mercados segmentados, e dos quais se espera que obtenham preços e margens de lucro relativamente altos. Na cadeia da soja, define-se como especialidade a soja livre de transgênicos (GMO FREE), que está sendo produzida em baixa escala, se comparada com o volume de produção mundial, e recebendo preços relativamente altos, representados pelos prêmios da segregação.
} 
Sendo assim, é de extrema relevância estudar a cadeia logística da soja após o advento dos transgênicos, com um olhar sistêmico, principalmente no que tange à relevância que a segregação dessa cadeia pode trazer para os agentes envolvidos e para a melhoria da competitividade de nosso país, com a oferta de uma soja diferenciada para os países que a demandarem.

\subsection{OBJETIVOS}

Contextualizado o tema, formulado e justificado o problema, o objetivo geral da tese é:

- Realizar uma análise sistêmica da cadeia logística da soja, a fim de identificar os atuais gargalos existentes, principalmente no que tange aos cuidados e procedimentos necessários para fazer a segregação, os riscos de contaminação e os tempos e custos adicionais, desde a compra da semente até sua exportação.

Os objetivos específicos são:

- Fazer um levantamento da atual cadeia logística da soja, a fim de se identificarem as variáveis que influenciam na segregação e contaminação da soja convencional;

- Identificar em quais elos da cadeia logística há maior possibilidade de contaminação da soja convencional pela transgênica, e os cuidados e procedimentos que devem ser adotados ao longo da cadeia para segregar o produto;

- Mensurar os tempos e os custos logísticos adicionais necessários para fazer a segregação da soja convencional ao longo da cadeia logística;

- Analisar o papel dos contratos como forma de mitigar os riscos de contaminação ao longo da cadeia logística, visando à garantia do produto livre de transgênicos e o recebimento do prêmio devido. 


\subsection{ESTRUTURA METODOLÓGICA DA PESQUISA}

\subsubsection{Discriminação das Etapas de Trabalho}

A cadeia da soja foi escolhida para este estudo devido à sua relevância para Brasil, sobretudo à nossa balança comercial, na qual a melhoria de qualquer processo logístico pode ajudar a impulsioná-la vertiginosamente, principalmente na entrega de produtos diferenciados, como é o caso da soja livre de transgênicos.

A literatura levantada sobre a Nova Economia Institucional (NEI) e Economia dos Custos de Transação (ECT) foi escolhida porque permite um olhar sistêmico sobre toda a problemática envolvida com a soja transgênica, principalmente no que tange aos ativos específicos que devem ser utilizados para fazer a segregação, e ao papel dos contratos que podem ajudar a minimizar os custos de transação e mitigar os riscos de contaminação ao longo da cadeia da soja. Para tanto, foi realizada uma revisão bibliográfica sistemática.

A literatura associada à Logística foi estudada por ser cada vez mais utilizada na resolução de problemas relacionados às Cadeias Logísticas Agroindustriais, permitindo uma visão holística de todos os processos logísticos envolvidos em cada elo. Além disso, essa literatura foi alicerce para fazer o levantamento de como se encontra a atual cadeia logística da soja brasileira (primeiro objetivo específico), mostrando onde se deve ter maiores cuidados para a não contaminação, bem como os pontos críticos que devem ser trabalhados com maior cautela, ou até mesmo ser segregados, para a garantia da oferta do produto puro. A literatura sobre a Cadeia Logística da Soja também deu suporte para a aplicação da pesquisa de campo, principalmente no desenho dos fluxogramas de cada etapa logística estudada, além de auxiliar no levantamento dos tempos e custos adicionais necessários para fazer a separação dos dois tipos de soja. Para o levantamento de tal suporte teórico, foi também realizada uma revisão bibliográfica sistemática.

Para responder ao primeiro objetivo específico, foi feito no Capítulo 3 um levantamento da atual cadeia logística da soja, por meio de uma revisão bibliográfica sistemática, para se ter uma visão das variáveis que influenciam na segregação e na contaminação da soja convencional. Para responder a este objetivo específico foi realizado um levantamento na 
literatura especializada, mostrando todos os processos que compõem a atual cadeia logística da soja, desde a compra da semente até sua chegada ao porto. Também foram levantados todos os elos que participam desse processo logístico (produtores rurais, armazenadores/processadores, transportadores rodoviários, operadores ferroviários e portuários), definindo os conceitos de cada um, qual seu papel, e onde se encontram dentro da atual cadeia. Além disso, foram identificados os problemas que cada elo vem enfrentando na atual configuração da cadeia logística da soja, como a utilização de estradas inapropriadas para o transporte, falta de armazéns, demora nos processos de carga e descarga, dentre outros. Foram mostrados também os principais corredores utilizados para a exportação da soja no Brasil, quem faz o transporte de cada percurso, e qual tipo de transporte utilizado.

Segundo Gil (2010), a pesquisa exploratória é o contato inicial com o tema a ser analisado, proporcionando maior familiaridade com o problema, com os sujeitos a serem investigados e com as fontes secundárias disponíveis. Esta modalidade de pesquisa foi utilizada para realizar um estudo preliminar do objetivo geral da pesquisa, ou seja, familiarizar-se com o fenômeno investigado, de modo que a pesquisa subsequente possa ser concebida com uma maior compreensão e precisão.

Posteriormente, foi feita uma pesquisa de campo junto aos elos logísticos envolvidos na cadeia da soja, os quais serão mostrados adiante. Para a coleta dos dados dessa pesquisa de campo, foram realizadas entrevistas semiestruturadas, que, na visão de Yin (2001), são mais espontâneas e assumem um caráter de conversa informal. No entanto, nesta abordagem, o pesquisador segue um roteiro de perguntas que permite obter a visão do pesquisador sobre o tema pesquisado.

A pesquisa de campo foi dividida em duas etapas, que são apresentadas separadamente para melhor compreensão.

\subsubsection{Primeira Etapa da Pesquisa de Campo}

Na primeira etapa, foi utilizada a observação direta intensiva, por meio de entrevistas com especialistas (23) participantes da cadeia logística da soja (produtores rurais, armazenadores/processadores, transportadores rodoviários, operadores ferroviários e 
portuários). Para a realização das entrevistas, utilizou-se um questionário semiestruturado com o intuito de entender como se dá a lógica e a organização da cadeia logística da soja, com todos os agentes envolvidos, desde a compra da semente até a colocação do produto no porto, passando por suas várias etapas logísticas, com uma visão sistêmica sobre o problema de pesquisa proposto.

As informações levantadas na primeira etapa da pesquisa de campo permitiram a confecção de todos os fluxos da cadeia logística da soja. Para isso, foi utilizada a técnica de representação gráfica ou fluxogramas ${ }^{15}$ (utilizada na literatura especializada da Engenharia de Métodos), a fim de mostrar onde estão os possíveis problemas de contaminação e onde deve haver maiores cuidados, ou até a total segregação dos ativos para evitar a contaminação da soja convencional. Todos os fluxogramas construídos estão apresentados no Capítulo 4 desta tese.

A simbologia e os respectivos significados utilizados nos fluxogramas foram apresentados na Figura 1.3.

\footnotetext{
${ }^{15} \mathrm{O}$ fluxograma é a representação gráfica das atividades ou fases de um processo, na sequência como elas ocorrem, permitindo entender, a partir da representação visual, como o processo é executado. O fluxograma mostra também: atividades desnecessárias ou que não agregam valor; gargalos e atrasos, evidenciando o desperdício; identifica clientes que passam despercebidos; e aponta oportunidades para melhoria em todo processo (CURY, 2000).
} 


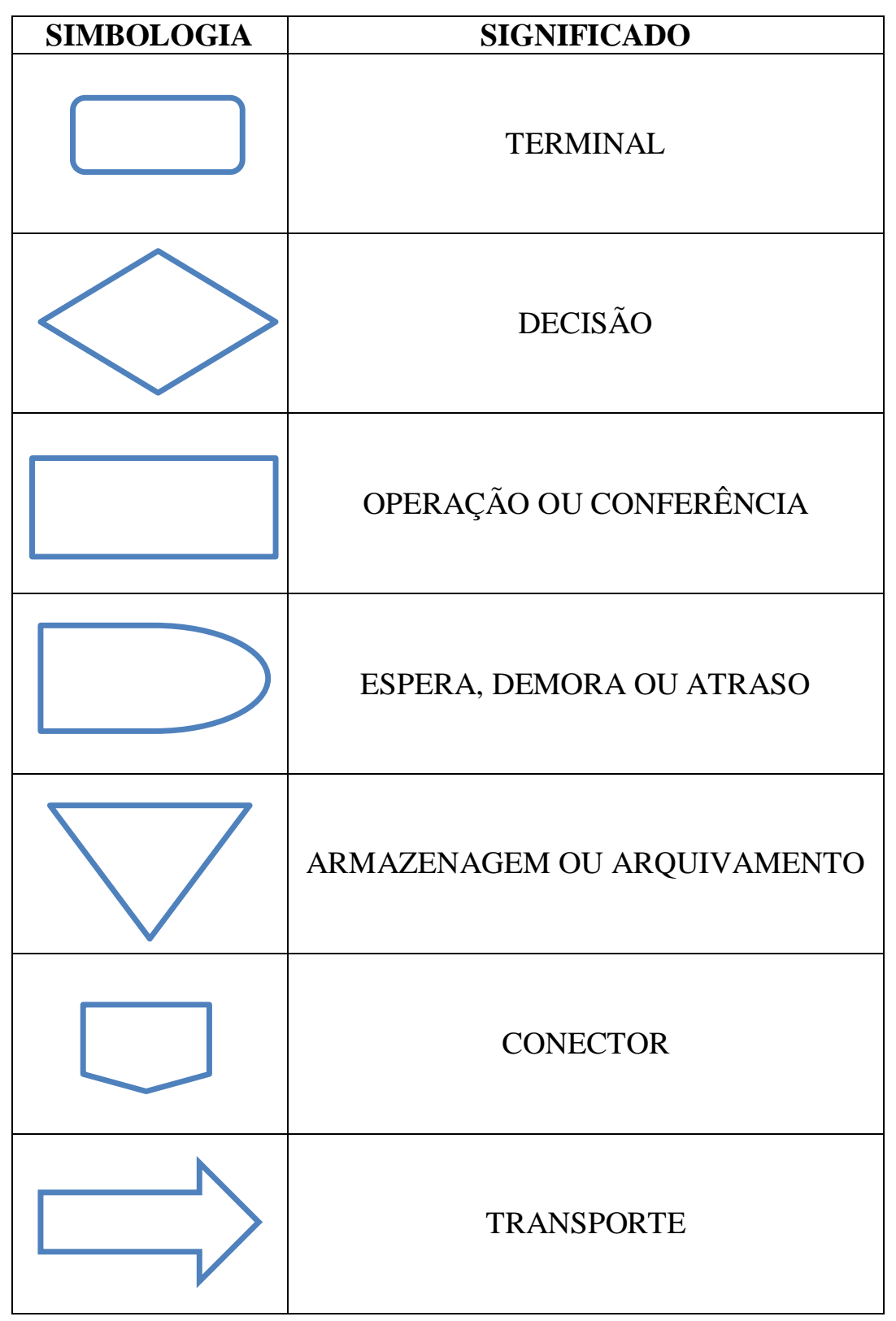

Figura 1.3: Simbologias e significados dos fluxogramas utilizados no desenho dos processos logísticos da cadeia da soja

Fonte: Cury (2000)

$\mathrm{Na}$ primeira etapa, foram entrevistados 23 agentes, sendo 12 produtores rurais ( 2 deles fazem a segregação da soja em suas propriedades, 10 deles deixaram de fazer devido à dificuldade operacional e aos altos investimentos necessários em ativos específicos), 4 armazenadores/processadores ( 1 deles é processador de soja e faz a segregação em sua unidade, e 3 deixaram de fazer a separação devido à dificuldade operacional e aos altos investimentos necessários em ativos específicos), 4 transportadores rodoviários (que trabalham com o transporte de soja transgênica e convencional), 1 operador ferroviário (que trabalha com o transporte de soja transgênica e convencional), e 2 operadores 
portuários (que trabalham com soja transgênica e convencional e fazem a expedição da soja livre de transgênicos para o mercado internacional).

O público alvo da pesquisa foi todos os agentes da cadeia logística da soja no Brasil que fazem ou já fizeram a segregação em alguma etapa logística, já que todos têm as mesmas dificuldades no processo de separação da soja. A taxa de rejeição das entrevistas na primeira etapa foi de $20 \%$. Na segunda, o percentual foi de $40 \%$.

Conforme relatado anteriormente, a Tabela 1.1 traz informações sobre a quantidade de agentes entrevistados em cada elo logístico, e adiciona a informação das cidades onde foram realizadas as entrevistas na primeira etapa da pesquisa.

Tabela 1.1: Agentes entrevistados na primeira etapa da pesquisa

\begin{tabular}{l|c|c}
\hline \hline \multicolumn{1}{c|}{ Agentes Entrevistados } & Qtde. & Cidade \\
\hline $\begin{array}{l}\text { Armazenadores/processadores que fazem a } \\
\text { segregação da soja }\end{array}$ & 1 & Araguari - MG \\
\hline $\begin{array}{l}\text { Armazenadores/processadores que já fizeram a } \\
\text { segregação da soja }\end{array}$ & 3 & $\begin{array}{c}\text { Unaí - MG (1); Paracatu - MG (1); } \\
\text { Buritis - MG (1) }\end{array}$ \\
\hline Produtores que fazem a segregação da soja & 2 & Unaí - MG (1); Arinos - MG (1) \\
\hline Produtores que já fizeram a segregação da soja & 10 & $\begin{array}{c}\text { Unaí - MG (4); Paracatu - MG (2); } \\
\text { Arinos - MG (2); Buritis - MG (2) }\end{array}$ \\
\hline Transportadores rodoviários & 4 & Unaí - MG (3); Paracatu - MG (1). \\
\hline Operador Ferroviário & 1 & Araguari - MG \\
\hline Operador Portuário & 2 & Porto de Tubarão - ES (1); e Porto de \\
Paranaguá - PR (1)
\end{tabular}

Fonte: Elaborado pelo autor (2014)

$\mathrm{Na}$ pesquisa de campo, foi constatado que os agentes supracitados que não fazem a segregação da soja na época da pesquisa, já o fizeram alguma vez. Todas as entrevistas foram gravadas para melhor compreensão e análise dos resultados, e foram realizadas pessoalmente (face a face) pelo próprio autor desta tese.

Para a realização das entrevistas na primeira etapa, foi feito um planejamento das questões, utilizando um pré-teste com cada um dos elos envolvidos. Este teste tinha o objetivo de validar, de garantir a fidedignidade das respostas, a operacionalidade da aplicação e a estimativa de resultados esperados. 
Segundo Gil (2010), quando o critério de representatividade dos grupos investigados é mais qualitativo que quantitativo (como na presente tese), é recomendável a utilização de amostras selecionadas pelo critério de intencionalidade, pois enriquece ainda mais a pesquisa do tipo qualitativa. Essa forma de amostragem é caracterizada como não probabilística. Nas amostras intencionais, enquadram-se os diversos casos em que o pesquisador deliberadamente escolhe certos elementos para pertencer à amostra, por julgar tais elementos bem representativos da população (COSTA NETO, 1977, p. 45).

Sendo assim, todos os produtores, armazenadores/processadores, transportadores rodoviários, operadores ferroviários e portuários entrevistados na primeira e segunda etapas da pesquisa foram escolhidos intencionalmente.

O Estado de Minas Gerais foi escolhido para a primeira etapa da pesquisa por apresentar uma produção significativa de soja ( $5^{\circ}$ maior estado produtor de grãos do Brasil) (SEAPA, 2014), e por estar distante dos portos de exportação, podendo assim ser mais afetado pelos problemas logísticos, principalmente no transporte e na armazenagem ao longo da cadeia (CONAB, 2014).

Os produtores e armazenadores/processadores de Unaí, Buritis, Arinos e Paracatu foram escolhidos por terem alta representatividade na produção de grãos do Estado de Minas Gerais. Segundo dados do IBGE (2010), a região Noroeste confirmou, na safra 2011/2012, a liderança na produção de grãos de Minas Gerais, com a colheita de 3 milhões de toneladas. Conforme avaliação da Secretaria de Estado de Agricultura, Pecuária e Abastecimento (SEAPA), esse volume equivale a 25,6\% da safra estadual (SEAPA, 2013). Unaí foi o município que mais contribuiu para a liderança da região na produção de grãos (maior produtor de grãos de Minas Gerais), com uma safra de 351 mil toneladas. Em seguida, estão Paracatu, com 280,8 mil toneladas, e Buritis, 273,6 mil toneladas cada (SEAPA, 2014).

O restante dos elos pesquisados (transportadores rodoviários, e operadores ferroviários e portuários), bem como as regiões da aplicação da pesquisa de campo, foram escolhidos intencionalmente. Esta escolha intencional se deu pelo fato de essas regiões fazerem parte do fluxo logístico que normalmente a soja do Noroeste faz até chegar ao porto. Sendo assim, a soja livre de transgênicos que sai de Unaí, por exemplo, tem como destino o 
armazém de Araguari - MG (via transporte rodoviário), para ser processada e, posteriormente, enviada (via transporte ferroviário) para o porto de Tubarão - ES (operador portuário), para expedição ao mercado internacional.

A Figura 1.4 mostra o fluxo escolhido para o estudo da pesquisa de campo da primeira etapa da pesquisa. O critério de escolha deste fluxo também foi intencional, por caracterizar-se como um "fluxo longo", e por apresentar maiores possibilidades de risco de contaminação do que um "fluxo curto", que poderia passar apenas pelos processos de carregamento do caminhão na fazenda do produtor e envio direto ao porto, sem passar por outras etapas logísticas de transporte, transbordo e armazenagem.

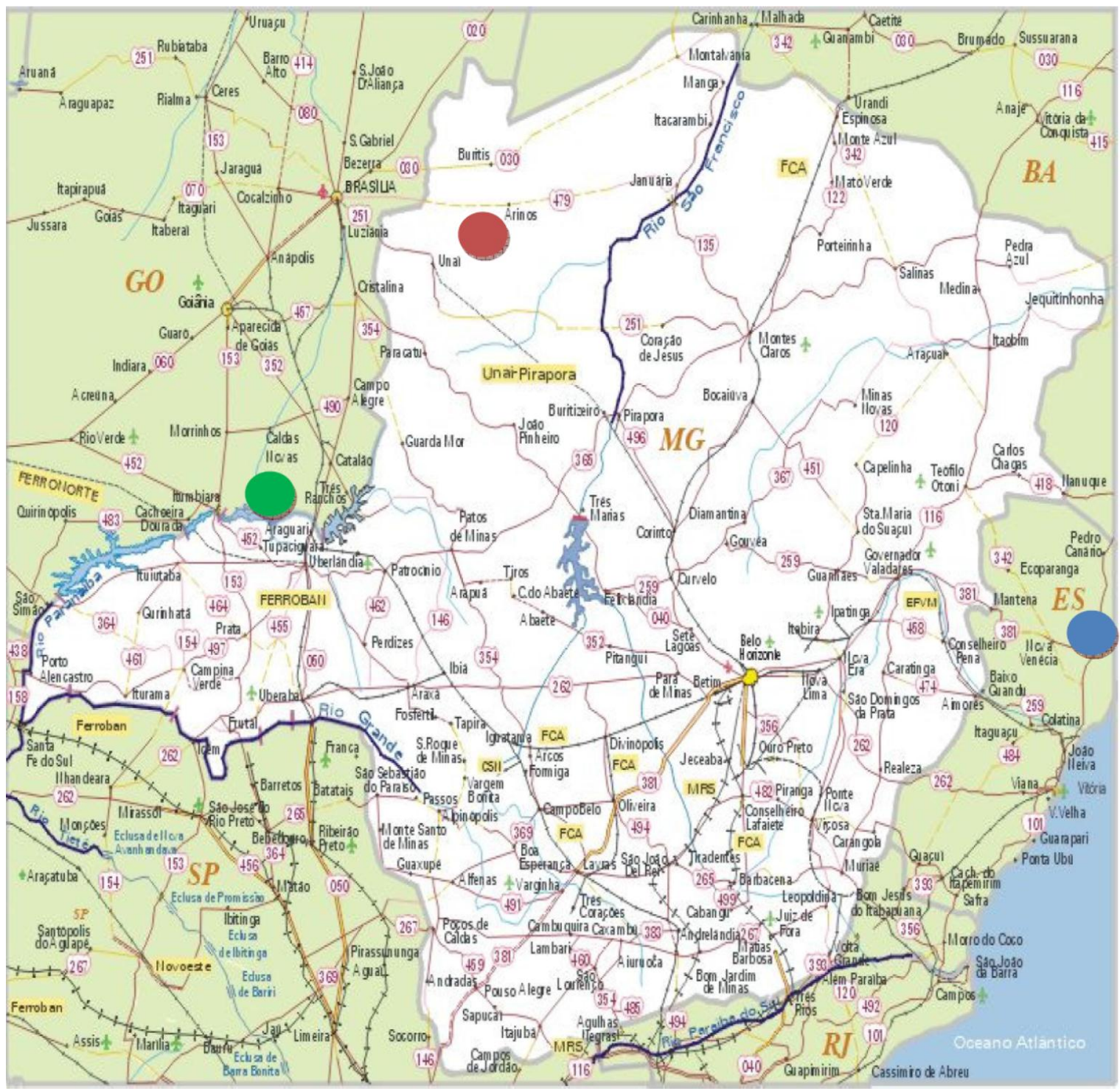

Figura 1.4: Percurso da soja da fazenda até o porto Fonte: Adaptado de Guia Geográfico (2013) 
A Figura 1.4 mostra que a soja é carregada em Unaí - MG (ponto vermelho), seguindo por modal rodoviário até Araguari - MG (ponto verde), onde será processada em farelo, e depois seguirá para o porto de Tubarão - ES (ponto azul) via modal ferroviário. Neste ponto, é descarregada em um armazém próximo ao porto, até sua expedição ao navio para o mercado internacional.

A Figura 1.5 mostra o fluxograma simples do processo citado anteriormente.

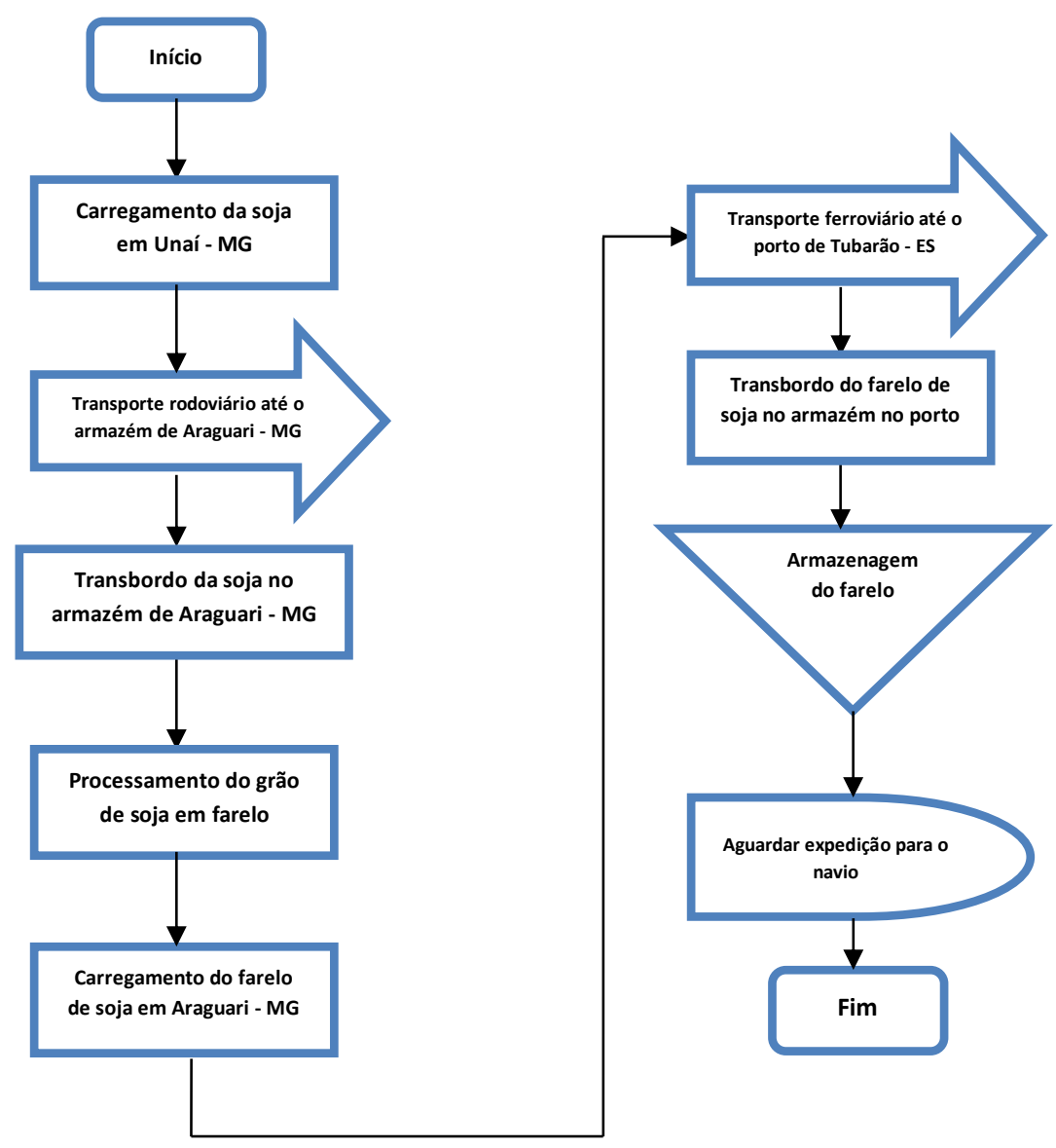

Figura 1.5: Fluxo do percurso da soja da fazenda do produtor até o porto Fonte: Elaborado pelo autor (2014)

A Figura 1.6 mostra de forma mais detalhada as etapas logísticas pelas quais a soja passa na cadeia, desde a origem na fazenda até seu destino final no porto, além de identificar os estágios onde o produto é armazenado e os modais utilizados para o transporte. 


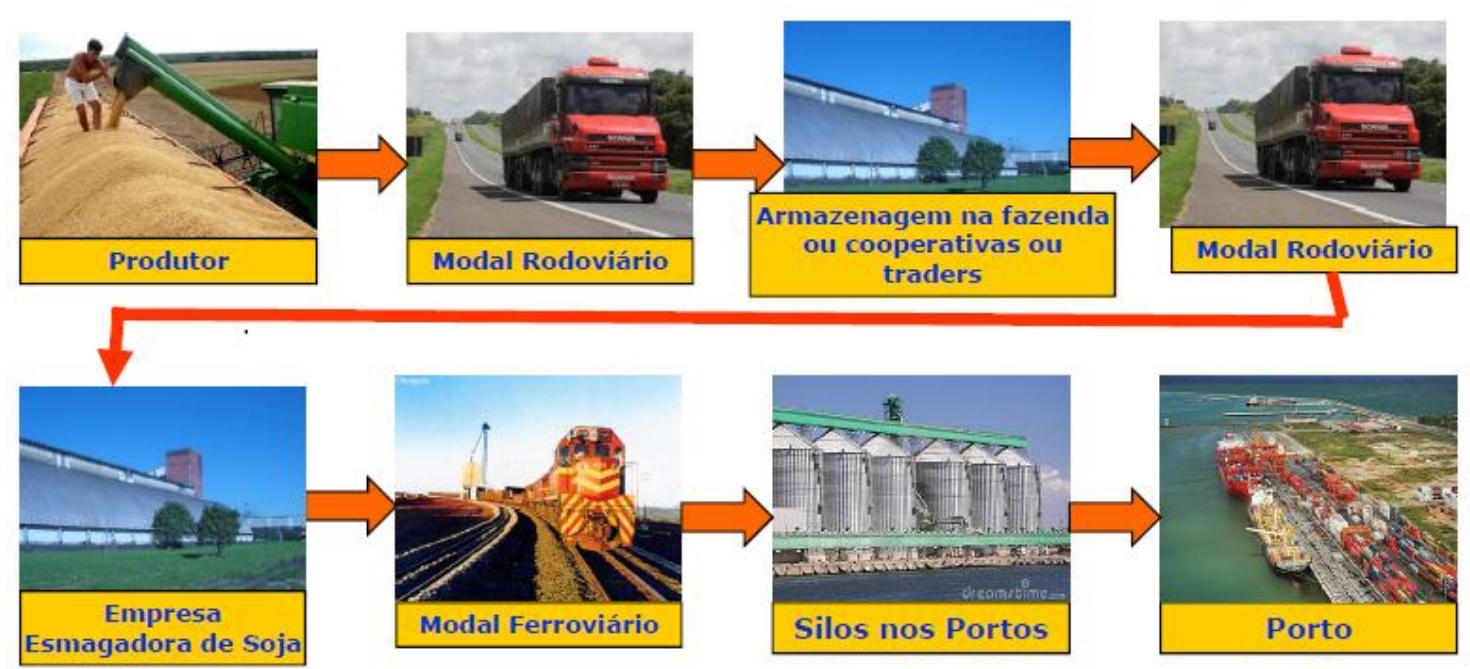

Figura 1.6: Processo logístico da soja da fazenda do produtor até o porto

Fonte: Elaborado pelo autor (2014)

A Figura 1.6 mostra que depois da soja ser colhida, o produtor faz o transporte via modal rodoviário até a sede da fazenda (caso tenha armazém), ou envia o produto para uma cooperativa ou trading, a qual fará o armazenamento até que o mesmo seja vendido. Depois de vendida, a soja segue via modal rodoviário até a empresa esmagadora (SELECTA), onde é armazenada e, posteriormente, processada em farelo para exportação. Depois que o farelo de soja é vendido pela SELECTA, segue via modal ferroviário até um armazém perto do porto de Tubarão, local onde é armazenado até sua expedição ao porto. Quando chega ao porto, a soja é armazenada nos porões dos navios para envio ao mercado internacional. Cada um desses processos serão mostrados em detalhe no Capítulo 4, utilizando a técnica de fluxogramas.

As informações levantadas na primeira etapa da pesquisa, apresentadas no Capítulo 4, permitiram responder ao segundo objetivo específico, o qual buscou identificar em quais processos da cadeia logística há maior possibilidade de contaminação da soja convencional pela transgênica, além dos cuidados e procedimentos que devem ser adotados ao longo da cadeia para garantir a pureza do produto.

\subsubsection{Segunda Etapa da Pesquisa de Campo}

As informações levantadas na primeira etapa foram o alicerce para a construção da segunda etapa da pesquisa. 
Para realizar a segunda etapa da pesquisa, foram selecionados novos agentes para serem entrevistados de cada elo logístico estudado na primeira etapa. A segunda etapa teve como objetivo consolidar os fluxos encontrados na primeira, ratificar os processos com maior possibilidade de contaminação e mensurar os tempos e custos adicionais dos procedimentos que são distintos nas duas cadeias. Também foram coletadas informações sobre a importância dos contratos na mitigação dos riscos de contaminação e o valor do prêmio recebido pela segregação.

A Tabela 1.2 traz informações sobre a quantidade e a cidade dos elos entrevistados na segunda etapa da pesquisa de campo.

Tabela 1.2: Agentes entrevistados na segunda etapa da pesquisa

\begin{tabular}{|c|c|c|c|c|}
\hline $\begin{array}{c}\text { Produtores que fazem } \\
\text { segregação }\end{array}$ & $\begin{array}{l}\text { Armazenadores - } \\
\text { processadores que } \\
\text { fazem segregação }\end{array}$ & $\begin{array}{c}\text { Transportadores } \\
\text { rodoviários de } \\
\text { soja }\end{array}$ & $\begin{array}{c}\text { Operadores } \\
\text { ferroviários de soja }\end{array}$ & $\begin{array}{l}\text { Operadores } \\
\text { portuários de } \\
\text { soja } \\
\end{array}$ \\
\hline 1 em Sorriso - MT & $\begin{array}{c}\text { IMCOPA (Cambé - } \\
\text { PR) }\end{array}$ & $\begin{array}{c}1 \text { em Sorriso - } \\
\text { MT }\end{array}$ & $\begin{array}{l}\text { América Latina } \\
\text { Logística (ALL) }\end{array}$ & Paranaguá - PR \\
\hline 1 em Sapezal - MT & $\begin{array}{c}\text { COMIGO (Rio } \\
\text { Verde - GO) }\end{array}$ & $\begin{array}{c}\text { em Sapezal - } \\
\text { MT) }\end{array}$ & MRS Logística S.A & Santos - SP \\
\hline $\begin{array}{c}1 \text { em Nova Mutun - } \\
\text { MT } \\
\end{array}$ & $\begin{array}{c}\text { CARAMURU } \\
\text { (Itumbiara - GO) }\end{array}$ & $\begin{array}{c}1 \text { em Nova } \\
\text { Mutun - MT }\end{array}$ & VALE S.A & $\begin{array}{c}\text { São Francisco } \\
\text { do Sul - SC }\end{array}$ \\
\hline $\begin{array}{c}1 \text { em Campo Novo dos } \\
\text { Parecins - MT }\end{array}$ & $\begin{array}{c}\text { LOUIS } \\
\text { DREYFULS (Alto } \\
\text { Araguaia - MT) }\end{array}$ & $\begin{array}{c}1 \text { em Campo } \\
\text { Novo dos } \\
\text { Parecins - MT) }\end{array}$ & & Vitoria-ES \\
\hline $\begin{array}{c}1 \text { em Formosa do Rio } \\
\text { Preto - BA }\end{array}$ & $\begin{array}{l}\text { CAROL (Orlândia } \\
-\mathrm{SP})\end{array}$ & $\begin{array}{c}1 \text { em Formosa do } \\
\text { Rio Preto - BA }\end{array}$ & & Santarém-PA \\
\hline 1 em Diamantino - MT & & $\begin{array}{l}1 \text { em Diamantino } \\
-\mathrm{MT} \\
\end{array}$ & & $\begin{array}{l}\text { Porto de Rio } \\
\text { Grande }- \text { RS }\end{array}$ \\
\hline $\begin{array}{c}1 \text { em Nova Ubiratan - } \\
\text { MT } \\
\end{array}$ & & $\begin{array}{c}1 \text { em Nova } \\
\text { Ubiratan }-\mathrm{MT} \\
\end{array}$ & & \\
\hline 1 em Rio Verde - GO & & $\begin{array}{c}1 \text { em Rio Verde - } \\
\text { GO }\end{array}$ & & \\
\hline $\begin{array}{c}1 \text { em Lucas do Rio } \\
\text { Verde - MT }\end{array}$ & & $\begin{array}{c}1 \text { em Lucas do } \\
\text { Rio Verde - MT }\end{array}$ & & \\
\hline $\begin{array}{c}1 \text { em São Desidério - } \\
\text { BA }\end{array}$ & & $\begin{array}{c}1 \text { em São } \\
\text { Desidério - BA }\end{array}$ & & \\
\hline 10 & 5 & 10 & 3 & 6 \\
\hline
\end{tabular}

Fonte: Elaborado pelo autor (2014)

$\mathrm{Na}$ segunda etapa, foram entrevistados 34 novos agentes. As entrevistas foram feitas por telefone devido à distância geográfica entre os agentes - seriam necessários muito tempo e recurso financeiro para fazê-las pessoalmente. $\mathrm{O}$ instrumento de coleta de dados foi o questionário semiestruturado. 
As cidades das entrevistas realizadas com os produtores e transportadores rodoviários foram escolhidas intencionalmente, por serem consideradas as 10 maiores cidades produtoras de soja do Brasil (IBGE, 2010).

Os armazenadores/processadores foram escolhidos por estarem fazendo a segregação da soja em suas unidades na época da pesquisa.

Os operadores ferroviários foram escolhidos por serem considerados os maiores em atividade do Brasil (ANTT, 2014).

Os operadores portuários foram escolhidos por serem os cinco maiores em volume de exportação de soja em grãos e farelo, de acordo com os dados da ALICEWEB/MDIC (2014)

Inicialmente, foi feito um contato telefônico com cada agente citado na Tabela 1.2, explicando o motivo da pesquisa. Neste contato, foi comunicado a eles que seriam enviados por e-mail os fluxos de sua etapa na cadeia logística (levantados na primeira etapa da pesquisa), para que identificassem onde há os maiores problemas da contaminação da soja, o papel dos contratos para mitigar esses riscos, e os tempos e custos adicionais para fazer a segregação de cada etapa. Também lhes foi perguntado o valor do prêmio recebido por fazer a segregação.

Nesse primeiro contato, também foi agendado o melhor dia para fazer a realização da entrevista. Todas as entrevistas foram realizadas em julho de 2014. Foi feito um pré-teste com cada um dos elos entrevistados na primeira semana do mês de julho. O pré-teste permitiu que todos os ajustes necessários fossem feitos antes da realização das entrevistas.

Para encontrar o valor final informado pelos agentes sobre os prêmios recebidos, os tempos e os custos adicionais para fazer a segregação, foi feita uma média aritmética simples com as informações concedidas por cada elo entrevistado. Por exemplo, dos cinco armazenadores/processadores entrevistados, o primeiro informou que o prêmio recebido é de $\mathrm{R} \$ 7,00$ a mais por cada saca de soja livre de transgênicos, o segundo 
informou ser de $\mathrm{R} \$ 9,00$, o terceiro, de $\mathrm{R} \$ 8,00$, o quarto disse ser de $\mathrm{R} \$ 9,00$ e o quinto, de $\mathrm{R} \$ 7,00$. Sendo assim, a média aritmética simples dos valores informados foi de $\mathrm{R} \$$ 8,00 .

Importante ressaltar que a média aritmética simples foi utilizada em detrimento da média aritmética ponderada pelo número reduzido de agentes entrevistados.

Com as respostas encontradas, foi possível responder ao terceiro e ao quarto objetivos específicos da tese, que versavam sobre o levantamento dos tempos e custos logísticos adicionais necessários para fazer a segregação da soja, e o papel dos contratos como forma de mitigar os riscos de contaminação ao longo da cadeia logística, visando à garantia do produto livre de transgênicos e o recebimento do prêmio devido.

Todas essas informações serão apresentadas no Capítulo 5 desta tese.

\subsubsection{Estrutura Metodológica da Pesquisa}

Neste item, apresenta-se a estrutura metodológica da pesquisa utilizada para a consecução dos objetivos pretendidos. Na Figura 1.7, estão discriminadas as etapas propostas para a solução do problema de pesquisa e o relacionamento lógico entre elas. 


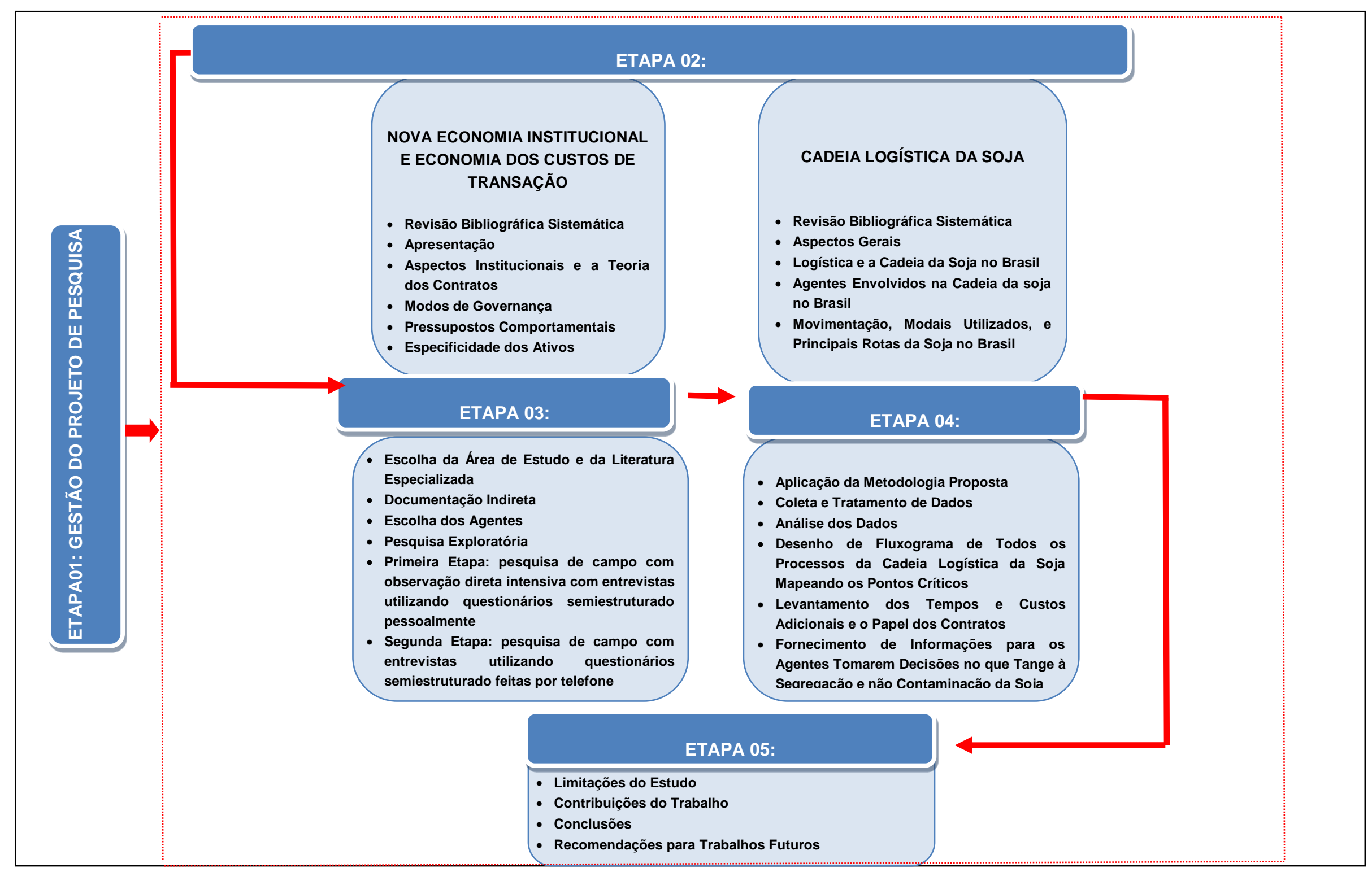

Figura 1.7: Esquema da metodologia empregada na pesquisa (Elaborado pelo autor, 2014) 
Etapa 1. Gerenciamento do Projeto de Pesquisa. Esta etapa abrangeu os procedimentos necessários para o planejamento, a execução e o controle deste trabalho, culminando com a elaboração de uma Estrutura Analítica de Projeto (EAP) da tese.

Etapa 2. Revisão Bibliográfica Sistemática. Consistiu no resgate literário e sua discussão acerca dos aspectos concernentes à Nova Economia Institucional e Economia dos Custos de Transação, principalmente àqueles relacionados à Teoria dos Contratos, à Especificidade dos Ativos Envolvidos e aos aspectos do Ambiente Institucional que podem influenciar a Cadeia Logística da Soja. Esta influência está associada, principalmente, aos aspectos relacionados no Brasil e no mundo sobre as estratégias de segregação que estão sendo utilizadas ao longo das cadeias logísticas, levantando os principais problemas de contaminação, os prêmios recebidos e a forma de fazer a segregação da cadeia, além de toda a problemática relacionada aos transgênicos. Sobre a Cadeia Logística da Soja, foram também levantados os agentes que estão envolvidos com o problema da segregação; os problemas enfrentados pelos transportadores rodoviário, ferroviário e operadores portuários; além do tratamento dos problemas relacionados à movimentação, modais utilizados e principais rotas de escoamento da soja no Brasil.

Foi utilizado como aporte teórico da NEI/ECT, com o intuito de realizar uma análise mais aprofundada das relações contratuais que afetam a cadeia logística da soja, estudos de Nort (1993), Williamson (1975, 1989, 1991, 1991B, 1993 e 1999), Coase (1937 e 1972), Zylberstajn (1995, 2000 e 2005), e Farina (1997), entre outros.

Embora tal arcabouço teórico tenha sido amplamente utilizado para análise de governança de cadeias de negócios, raras são as aplicações em aspectos específicos da logística. Autores como Ruijs, Schweigman e Lutz (2004), Villa (2007), Levinson e Odlyzko (2008), e Henesey e Persson (2011) têm trabalhado com a Nova Economia Institucional e a Economia dos Custos de Transação relacionados à logística. Porém, nenhum deles tem trabalhado com a aplicação da NEI/ECT no âmbito das cadeias agroalimentares, como é o caso da soja. Esta pode ser entendida como uma abordagem inovadora deste trabalho. 
Para dar sustentação à discussão do aporte teórico da Cadeia Logística da Soja, foram utilizados conceitos relacionados à logística estudados por Ballou (1993, 2001 e 2006), Bowersox e Closs (2001 e 2006), Robeson e Copacino (1994), Alvarenga et al., (2000), Carvalho (2002), Dornier, Ernst e Fender (2000), Fleury, Wanke e Figueiredo (2000), Novaes (1993), dentre outros.

Etapa 3. Proposta Metodológica. Versou sobre a consolidação da proposta metodológica, sobre as técnicas utilizadas para entender melhor a cadeia logística da soja, após a difusão dos transgênicos, sobre o levantamento dos pontos críticos passíveis de contaminação, bem como sobre os tempos e os custos adicionais para fazer a segregação da cadeia logística da soja, além da escolha, identificação e análise dos principais grupos de atores envolvidos.

Etapa 4. Aplicação Metodológica. Buscou descrever a execução das etapas e subetapas da metodologia proposta; coleta e tratamento de dados; análise dos dados; classificação; desenho dos fluxogramas de todos os processos envolvidos na Cadeia Logística da Soja; mapeamento dos pontos críticos; consolidação dos fluxos; levantamento dos tempos e custos adicionais para fazer a segregação; papel dos contratos na coordenação e mitigação dos riscos de contaminação ao longo da cadeia logística; e fornecimento de informações para os agentes tomarem decisões no que tange à segregação e não contaminação da soja.

Etapa 5. Conclusões e Recomendações Finais. Compreendeu a análise da aplicabilidade da metodologia proposta, abordando as conclusões obtidas com a pesquisa, contribuições do trabalho, as dificuldades encontradas, limitações e as indicações para futuros estudos.

\subsection{ESTRUTURA DA TESE}

A tese encontra-se estruturada em 6 capítulos.

O Capítulo 1 apresenta a introdução ao estudo desenvolvido, contextualizando a formulação do problema científico a ser solucionado e descrevendo a justificativa, os objetivos, a estrutura metodológica da pesquisa e a estrutura da tese. 
Os Capítulos 2 e 3 abordam a revisão bibliográfica sistemática e sua discussão, apresentando os pilares referenciais para o desenvolvimento da tese. No capítulo 3 , foi possível fazer a identificação da atual situação da cadeia logística da soja brasileira, além de apresentar as mudanças pelas quais ela vem passando após o advento e a difusão da soja transgênica.

O Capítulo 4 trata dos pontos críticos para o processo de segregação e não contaminação da cadeia logística da soja brasileira, desde a compra de insumos até a colocação do produto no porto para exportação, passando por todas as etapas logísticas. Trata também da legislação e das condições comerciais dessa cadeia após o advento dos transgênicos.

O Capítulo 5 trata do levantamento dos tempos e custos adicionais para fazer a segregação e o papel dos contratos como mitigador de riscos de contaminação ao longo da cadeia logística, além do levantamento dos prêmios recebidos pelos agentes para fazer a segregação.

O Capítulo 6 contém as limitações de estudo, as contribuições do trabalho, as conclusões, e, por fim, as recomendações para trabalhos futuros.

Na última parte, as Referências Bibliográficas encerram o presente trabalho. 


\section{NOVA ECONOMIA INSTITUCIONAL E ECONOMIA DOS CUSTOS DE TRANSAÇÃO}

\subsection{APRESENTAÇÃO}

O estudo de Coase, The Nature of the Firm (1937), deu origem à NEI. Mais tarde, surgiu a ECT, baseada na seguinte questão: por que toda a produção não é realizada em uma única grande firma? Coase critica a visão neoclássica que considera a firma como função de produção, uma relação mecânica. Ele diz que a firma está presente em uma relação orgânica entre os agentes, que se realiza através de contratos implícitos ou explícitos (ZYLBERSZTAJN, 2000).

Coase foi além do estudo da função de produção e procurou entender o escopo, a abrangência e os limites de uma firma. Relatou que o pensamento econômico, de um modo geral, tinha como último e principal propósito aperfeiçoar as proposições de Adam Smith sobre a coordenação do sistema econômico através do mecanismo de preços (AZEVEDO, 1996).

A corrente de estudo de Coase foi representada principalmente por Oliver Williansom e Douglas North e teve a colaboração de diversos autores que contribuíram para a sua consolidação.

Para Willianson (1991, p.32), custos de transação podem ser definidos como:

Os custos ex-ante de preparar, negociar e salvaguardar um acordo bem como os custos ex-post dos ajustamentos e adaptações que resultam, quando a execução de um contrato é afetada por falhas, erros, omissões e alterações inesperadas. Em suma, são os custos de conduzir o sistema econômico.

Sobre as transações entre os agentes dos elos da cadeia logística, é fundamental que haja salvaguardas na presença de ativos específicos (acontece com frequência na agricultura), para que não haja quebra de contrato oportunista (quando há). Em muitos casos, essas salvaguardas são insuficientes, caindo no pressuposto da racionalidade limitada, a qual impede a elaboração de contratos completos. Esses pressupostos complementares que a teoria neoclássica não abordou são de suma relevância na análise 
das transações no mundo atual, e extremamente importantes nas transações entre os elos da cadeia logística da soja para melhor entender como se dão as transações entre eles, bem como para saber onde são necessários investimentos em ativos específicos para a segregação da soja, além de ajudar no entendimento do papel que os contratos assumem para mitigar o risco de contaminação ao longo da cadeia logística.

Todo o alicerce desse referencial está descrito a seguir.

\subsection{ASPECTOS INSTITUCIONAIS E A TEORIA DOS CONTRATOS}

Estudar como se dão as transações e os contratos entre os agentes da cadeia logística da soja é essencial para saber qual é a influência destes contratos na estruturação da cadeia, uma vez que eles podem ser formas de incentivo/controle para que os agentes não contaminem a soja ao longo da cadeia e consigam oferecer um produto puro.

$\mathrm{Na}$ economia, a teoria do contrato estuda como os atores econômicos constroem arranjos contratuais, geralmente na presença de informação assimétrica. Devido a suas conexões com representação e incentivos, a teoria do contrato é muitas vezes categorizada dentro de um campo conhecido como análise econômica do direito. Uma aplicação importante disso é a concepção de esquemas ótimos de compensação gerencial. No campo da economia, o primeiro tratamento formal deste tópico foi dado por Kenneth Arrow, na década de 1960.

Para Zilberstajn (2005), os contratos surgem como estruturas de amparo às transações e visam a controlar a variabilidade e mitigar os riscos, aumentando o valor da transação ou de um conjunto complexo de transações. Ainda de acordo com Zilberstajn, a ECT é relevante e deve ser bem compreendida para o estudo dos contratos em geral e os que envolvem a agricultura em particular.

Farina (1997, p.16) tem uma visão convergente ao autor supracitado e diz que:

o sistema agroindustrial de alimentos passou a ser tratado como um nexus de contratos formais e informais, cujo objetivo é coordenar a cadeia logística, provendo estímulos, controles e agilizando o fluxo de informação do mercado para todos os segmentos componentes do sistema. 
Elementos antes considerados exógenos à análise econômica, como direitos de propriedade, estrutura organizacional da firma e mecanismos de governança das transações, passaram, um a um, a ser incorporados na NEI. Possivelmente, uma das maiores contribuições de Ronald Coase foi o enriquecimento da visão da firma, a qual passa de um mero depositário de atividade tecnológica de transformação de produto para um complexo de contratos regendo transações internas (AZEVEDO, 1996).

Além dos pressupostos comportamentais (oportunismo e racionalidade limitada), há também atributos inerentes às transações entre os agentes da cadeia logística da soja, as quais se relacionam com os pressupostos comportamentais, como: incerteza, frequência e especificidades dos ativos.

A incerteza é uma variável do ambiente, e ocorre diante da impossibilidade de se prever com precisão o comportamento dos agentes. Na cadeia logística da soja, a incerteza é patente, porque não se sabe ao certo quando pode haver o pagamento de prêmios, haja vista que não são todos os produtores que dizem receber esse benefício (LEITÃO, 2009). O recebimento do prêmio está intimamente ligado aos contratos que os produtores fazem com armazenadores/processadores para a entrega do produto livre de transgênicos, assumindo a responsabilidade da segregação desde a compra da semente até a entrega do grão para a indústria processadora. Não são todas as empresas, todavia, que fazem esse tipo de contrato (LEITÃO, 2009). O valor do prêmio recebido também é variável, a depender da região em que ela é vendida.

O princípio da precaução está intimamente relacionado com as incertezas que a cadeia logística da soja está passando, após a difusão dos transgênicos, e ajuda a entender melhor essas dúvidas. Este conceito é desenvolvido com a intenção de evitar que danos desconhecidos hoje surjam no futuro, não permitindo que a ausência de uma certeza científica seja usada para atrasar uma ação preventiva. Em outras palavras, o conceito versa sobre os cuidados e procedimentos que devem ser adotados ao longo da cadeia logística da soja, para que não haja a contaminação, mas sim a garantia da oferta do produto livre de transgênicos. 
O Princípio 15 - Princípio da Precaução - da Declaração do Rio/92 sobre Meio Ambiente e Desenvolvimento Sustentável foi proposto na Conferência no Rio de Janeiro, em junho de 1992. A Conferência o definiu como "a garantia contra os riscos potenciais que, de acordo com o estado atual do conhecimento, não podem ser ainda identificados". De forma específica assim diz o Princípio 15:

\begin{abstract}
Para que o ambiente seja protegido, serão aplicadas pelos Estados, de acordo com as suas capacidades, medidas preventivas. Onde existam ameaças de riscos sérios ou irreversíveis, não será utilizada a falta de certeza científica total como razão para o adiamento de medidas eficazes, em termos de custo, para evitar a degradação ambiental (MINISTÉRIO DO MEIO AMBIENTE, 2014).
\end{abstract}

Nos artigos 10 e 11, do Protocolo de Cartagena sobre Biossegurança, o Princípio da Precaução é mencionado como:

\begin{abstract}
a ausência de certeza científica devida à insuficiência das informações e dos conhecimentos científicos relevantes sobre a dimensão dos efeitos adversos potenciais de um organismo vivo modificado na conservação e no uso sustentável da diversidade biológica na Parte importadora, levando também em conta os riscos para a saúde humana, não impedirá esta Parte, a fim de evitar ou minimizar esses efeitos adversos potenciais, de tomar uma decisão, conforme o caso, sobre a importação do organismo vivo modificado (MINISTÉRIO DO MEIO AMBIENTE, 2014).
\end{abstract}

Segundo o Ministério do Meio Ambiente (2014), o Principio da Precaução tem quatro componentes básicos: (i) a incerteza passa a ser considerada na avaliação de risco; (ii) o ônus da prova cabe ao proponente da atividade; (iii) na avaliação de risco, um número razoável de alternativas ao produto ou processo devem ser estudadas e comparadas; e (iv) para ser precaucionária, a decisão deve ser democrática, transparente e ter a participação dos interessados no produto ou processo.

Myhr e Traavik (2003) trabalharam com o conceito do princípio da precaução e os conflitos de interesses associados à produção de sementes geneticamente modificadas, e já levantavam algumas incertezas que poderiam emergir quanto a sua produção, a saber: qual o nível de risco aceitável que a população estava disposta a assumir?; quanto de contaminação pode o homem ou o ecossistema assimilar sem mostrar efeito adverso?; quanta contaminação pode ser evitada enquanto se mantêm certos valores?; qual é a real necessidade e pertinência da atividade? 
Caso fosse cobrado o princípio da precaução dos agentes da cadeia logística da soja, as incertezas quanto à contaminação poderiam ser reduzidas vertiginosamente, pois o ônus da prova seria assumido por cada elo da cadeia que a contaminasse, garantindo, assim, a oferta do produto livre de transgênicos.

Outra característica da transação trabalhada na ECT é a frequência. Essa diz respeito à quantidade de vezes que determinada transação é realizada. Com o advento da soja transgênica no mercado brasileiro, as transações entre os agentes da cadeia logística da soja aumentaram consideravelmente. Estudos de Bragagnolo et al.(2007), Leitão (2009), Esperancini et al. (2008), Medeiros et al. (2009), e Fuscaldi, Medeiros e Pantoja (2012), demonstram essa evolução. Esse aumento no número das transações pode ser visualizado na Figura 2.1, a qual mostra o aumento da frequência das transações das empresas originadoras/processadoras com outros agentes ao longo da cadeia da soja.

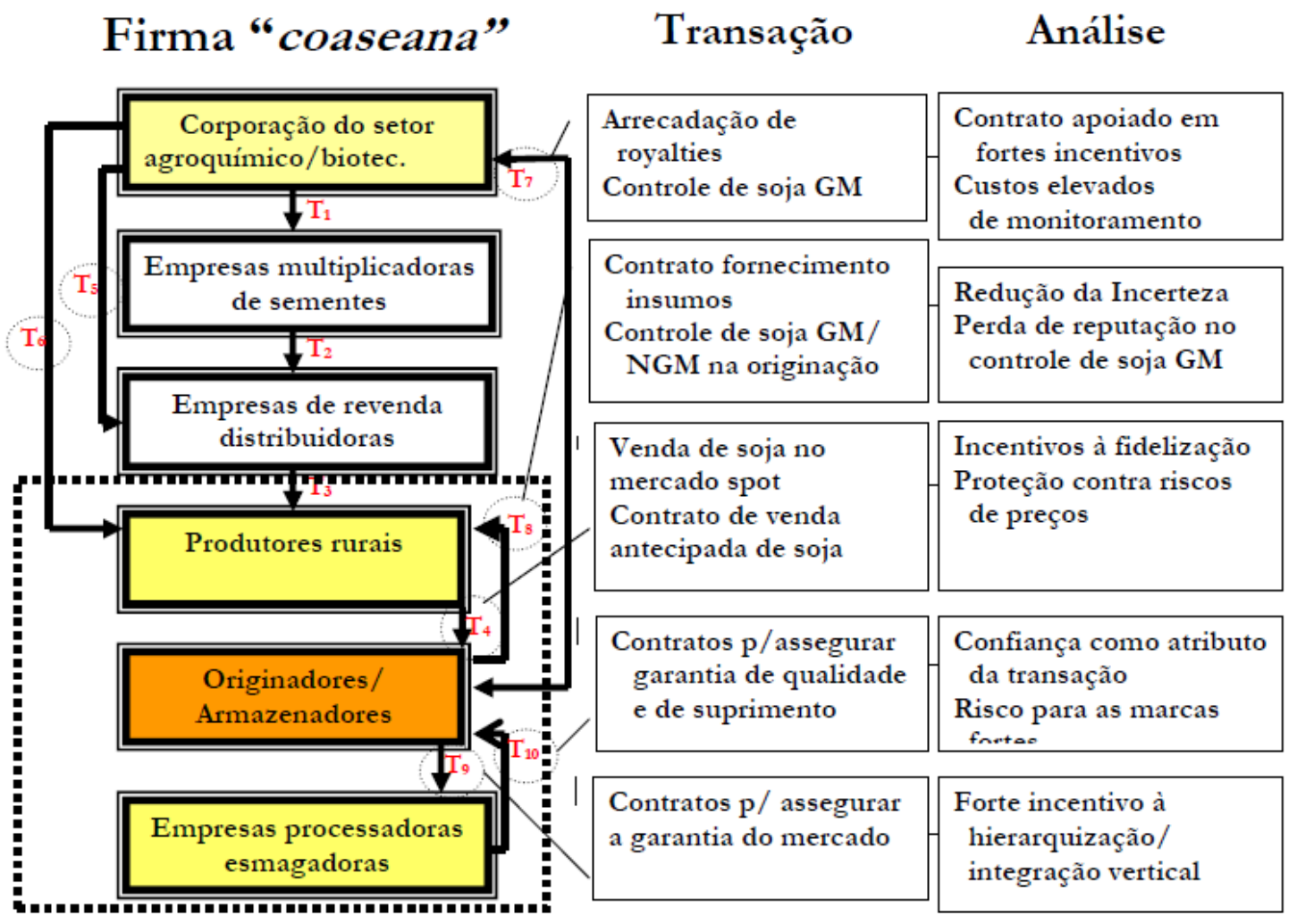

Figura 2.1: A natureza coaseana da empresa originadora/processadora e suas transações

Fonte: Medeiros et al. (2009) 
Outra característica da transação que deve ser analisada diz respeito à especificidade dos ativos, que é o grau em que determinado ativo pode ser reaproveitado em outra atividade. Logo, quanto menos aproveitável, maior será sua especificidade. Por essa característica ser relevante para o presente estudo, foi criado um item para que fosse mais bem discutido, o qual será mostrado posteriormente.

De acordo com o modelo analítico proposto por Williamson (1989), é possível prever a melhor estrutura de governança a ser utilizada, considerando apenas os atributos das transações e dos agentes. As transações podem se realizadas via mercado, via contratos e por via hierárquica, ou ainda assumir uma forma híbrida de governança. Adotando-se a melhor estrutura de governança, é possível diminuir os custos de transação, e possivelmente os custos da segregação.

Sob o ponto de vista da ECT, o ambiente institucional é composto de instituições responsáveis por impor restrições e liberdades aos atores componentes de uma sociedade, servindo de parâmetro à seleção de regras formais e informais. As instituições servem como "moderadores" nas relações entre o indivíduo e a coletividade, constituindo-se em um espaço no qual os interesses individuais podem ser "agrupados" em interesses coletivos, expressos por uma organização representativa.

North (1993) define as instituições como sendo as "regras do jogo" em uma sociedade, ou como sendo as restrições humanamente concebidas para moldar a interação humana. De acordo com o autor, fazem parte do ambiente institucional: cultura, tradições, educação, costumes, regras e aparato legal.

Na concepção de North, as instituições se originaram ao longo da história com a finalidade de criar ordem e reduzir as incertezas, podendo ser consideradas como a expressão concreta da mentalidade das pessoas. Como as pessoas pensam de forma diferente, há instituições bastantes distintas umas das outras. Junto às restrições econômicas, as instituições determinam os custos de produção e de transação, influenciando, portanto, na rentabilidade e na viabilidade de determinada atividade. Dessa forma, as instituições influenciam diretamente na decisão dos agentes econômicos e dos atores envolvidos em determinados setores. 
North (1993) chama a atenção para o fato de que as instituições podem favorecer o crescimento, a estagnação ou o declínio do sistema econômico. A NEI não foi desenvolvida para ser aplicada sobre um setor específico, podendo servir de base teórica para diversos setores, dentre eles, o agronegócio. No entanto, Azevedo (1997, p. 34) ressalta que, apesar de a NEI apresentar um arcabouço genérico, "as instituições que condicionam os negócios agrícolas e seu entorno são particulares" o que torna interessante sua apresentação nesse contexto específico.

Diante do exposto, os contratos serão formatados levando em consideração as características das transações e dos agentes envolvidos, sendo este de fundamental importância para a melhoria da atual cadeia logística da soja, servindo de mecanismos de incentivo/controle para que possa mitigar a contaminação da soja convencional pela transgênica.

\subsection{MODOS DE GOVERNANÇA}

Em Williansom (1989), a linha de investigação do comportamento organizacional das empresas é abordada de forma conceitual, e não como uma função de produção, conforme descrita tradicionalmente pelos neoclássicos. Comparativamente, o autor posiciona essa abordagem teórica como: a) mais microanalítica; b) mais consciente de seus supostos comportamentais; c) capaz de introduzir e desenvolver a importância econômica da especificidade dos ativos; d) recorrendo mais à análise institucional comparada e; e) capaz de ganhar um peso maior as instituições contratuais ex post, com interesse maior no ordenamento privado por oposição ao ordenamento judicial (MARTINS, XAVIER e SPROESSER, 2010).

O autor sustenta que a "transação" é a unidade básica de análise e insiste que ela é a determinante da forma de organização. A transação é uma operação na qual são negociados direitos de propriedade. Nesse sentido, Zylbersztajn (1995) coloca a firma como "um complexo de contratos", sendo que a governança do sistema pode ser via firma (hierárquica), via mercado ou mista, a partir da busca de minimização dos custos de produção (neoclássicos) e dos custos de transação (MARTINS, XAVIER; SPROESSER, 2010). 
A possibilidade de redução do comportamento oportunista pode ser atingida pela elaboração de contratos de longo prazo, os quais podem limitar, por outro lado, a habilidade das partes em renegociar. No entanto, isso seria limitar as partes à renegociação de um acordo que não é mais apropriado, dada as possíveis mudanças circunstanciais que podem ser prejudiciais à relação comercial.

Como estrutura de governança, ou tipos de arranjos alternativos, há três estruturas básicas de coordenação: mercado, hierárquicas ou integração vertical e estruturas híbridas, conforme definido por Williamson (1993 e 1999), Humphrey e Schmitz (2000) e Schmitz (2000).

Na Hierarquia ou Integração Vertical, a firma "internaliza" as operações, que antes eram executadas por outro agente, ou utiliza a contratação interorganizacional, visando a suprir suas necessidades de insumo.

As Estruturas Híbridas são as formas intermediárias de governança de mercado e hierárquica, combinando fatores dos dois extremos. Nessa categoria, os contratos implicam elementos mais flexíveis e informais de coordenação, em períodos de conturbações não antecipadas do ambiente econômico e competitivo.

A matriz de governança que analisa as características das transações e dos agentes sofreu transformações, conforme levantado por diversos autores (LEITÃO et al., 2008; LEITÃO, 2009; LEITÃO et al., 2010; LEITÃO et al., 2012; MEDEIROS et al., 2007; MENDEZ DEL VILLAR, 2007).

O estudo de governança visa a identificar os principais aspectos das relações estabelecidas entre o ambiente institucional e os atores sociais, a fim de determinar sua eficiência, no que tange à redução dos seus custos de transação. Estes custos, conforme Wiliamson (1999, p. 12), constituem "um esforço para identificar, explicar e mitigar os riscos contratuais". Williamson (1999) destaca ainda que a transação é a unidade básica de análise, sendo a governança um mecanismo para se estabelecer uma ordem em relação a potenciais ameaças de conflito, com vistas a aproveitar oportunidades e realizar ganhos mútuos. 
Para Joskow (1985), a situação de incerteza explica o motivo pelo qual compradores e vendedores não conseguem firmar contratos livres de ambiguidades e que tenham cláusulas que cubram todas as contingências.

Outro fator que gera incerteza é o mercado dominado pelo oportunismo, que constitui ação voltada ao autointeresse, estritamente como a transmissão de informação seletiva ou distorcida, e promessas ou compromissos que o agente sabe, em princípio, que não cumprirá. Este tipo de situação é verificado em jogos não cooperativos (WILLIAMSON, 1993; FIANI, 2002).

Para tanto, a rapidez das informações ao longo das cadeias e a reação dos atores em relação a impactos (cooperação e conflito) devem ser considerados na análise do desenho institucional, que deve contribuir para o ajustamento rumo ao novo equilíbrio (ZYLBERSZTAJN, 1995). Com a adoção dos transgênicos, há muitas informações ainda assimétricas, o que afetaria na melhor arquitetura e menor velocidade com que as informações deveriam fluir, afetando diretamente a eficiência da cadeia logística.

Outros autores como Alchian e Demsetz (1972), Grossman e Hart (1986), Hart e Moore (1990) e Fligstein (2001) deram relevante contribuição para o estudo de governança ao destacarem os direitos de propriedade. Para eles, o direito de propriedade tem papel central na compreensão dos sistemas econômicos, pois constitui um fator de vantagem competitiva. Os direitos de propriedade, assim como a regulamentação no uso dos recursos naturais, também permitem delinear formas de governança distintas que, de modo geral, visam a diminuir os custos de transação do sistema econômico.

A teoria sobre integração vertical começou a ser difundida na literatura econômica a partir da metade dos anos 1980, com a publicação do livro de Oliver Williamson, The Economic Institutions of Capitalism (1985), e com o artigo publicado por Grossman e Hart, The Costs and Benefits of Ownership: a Theory of Vertical and Lateral Integration (1986). Estas abordagens apoiadas nas contribuições de Coase, Arrow e Simon delinearam os estudos sobre integração vertical (AZEVEDO, 1996). 
A integração vertical é definida como a "organização de dois processos sucessivos por uma mesma firma", em que vertical se refere aos processos produtivos e integração à organização desses processos pela mesma firma (AZEVEDO, 1996, p. 3).

Quando um agente decide pela integração vertical, toma a decisão de produzir determinado bem que poderia ser comprado no mercado ou através de contratos préfixados.

A governança hierárquica é aquela em que a autoridade é claramente internalizada dentro de grandes empresas, em que toda a capacidade de coordenar as relações econômicas e tecnológicas, no âmbito local, ocorre por meio dela (AMORIM, 1998; GARCIA; ROMEIRO, 2009).

Diferentemente da integração vertical, existem as transações via mercado $\operatorname{Spot}^{16}$, que se caracterizam por transações resolvidas em um único instante de tempo. O mercado Spot, além de ser esporádico, apresenta alta dose de incertezas, seja em relação ao comportamento dos preços, seja à qualidade dos produtos adquiridos (AZEVEDO, 1997).

$\mathrm{Na}$ governança de mercado, a coordenação é estabelecida pelos agentes econômicos globais, ou seja, o mercado coordena as relações envolvidas entre os agentes (AMORIM, 1998; GARCIA; ROMEIRO, 2009).

Já a governança de cooperações bilaterais ou multilaterais pode ser tanto horizontal quanto vertical (SCHMITZ, 2000). Na cooperação bilateral horizontal, há empresas concorrentes que buscam desenvolver um trabalho específico, ao passo que a cooperação bilateral vertical compreende empresas envolvidas em distintas fases da cadeia produtiva, mas com objetivos e interesses comuns.

Nas cooperações multilaterais, a do tipo horizontal representa empresas concorrentes, cujos projetos são coordenados por organismos públicos e/ou privados, enquanto que a

\footnotetext{
${ }^{16}$ A palavra spot - ponto, em inglês - é empregada em economia para qualificar um tipo de mercado, cujas transações se resolvem em um único instante do tempo (AZEVEDO, 1997, p. 56).
} 
cooperação multilateral vertical envolve empresas e instituições pertencentes a cadeias diferentes, mas com fortes relações e objetivos comuns.

\subsection{PRESSUPOSTOS COMPORTAMENTAIS}

A existência dos custos de transação está relacionada ao reconhecimento de que os atores econômicos possuem racionalidade limitada e podem agir de forma oportunista. Por um lado, a racionalidade limitada impede a configuração de um contrato completo, devido à escassez na capacidade da mente humana em obter, absorver e processar todas as contingências futuras relacionadas ao contrato. Por outro lado, em decorrência da incompletude dos contratos, e assumindo ainda que o indivíduo possa agir com oportunismo, pode ocorrer rompimento contratual entre as partes transacionadas com o objetivo de se apropriar da renda da outra parte.

O oportunismo parte do pressuposto que os atores econômicos se guiam por interesses próprios, e não por um comportamento altruístico. Isto pode implicar uma ação dolosa em busca do próprio interesse e tem profundo significado na escolha entre as relações contratuais alternativas. Buscar o autointeresse é até aceitável, porque se trata das características do ser humano; só não é, quando este o busca com avidez (WILLIAMSON, 1991).

A economia neoclássica considera que a racionalidade é completa e ilimitada. Entretanto, Simon (1961) explica que a escassez pode estar relacionada à falta de capacidade dos atores econômicos em obter, absorver e processar a informação. A racionalidade limitada se refere ao comportamento humano que é "deliberadamente racional, porém limitadamente" (SIMON, 1961, p. 24). Com base na visão de Simon, é necessário saber se a racionalidade limitada é uma variável que atrapalha a condução da cadeia logística de forma eficiente, principalmente pensando na arquitetura dos contratos entre os agentes como forma de mitigar os riscos de contaminação.

A racionalidade limitada extrapola limites neurofisiológicos e de linguagem. Os indivíduos são limitados no processo de receber, armazenar, recuperar e processar as informações sem erros. Isto acontece porque os seres humanos estão limitados ao conhecimento, previsão, habilidade e tempo (WILLIAMSON, 1991). 
O pressuposto comportamental de racionalidade limitada é mais intenso em condições de incerteza e complexidade do ambiente, podendo ocasionar problemas econômicos de agentes que se utilizam do oportunismo para levar vantagem sobre outro agente. Exemplo disso é a utilização de informações privilegiadas.

Segundo Azevedo (1999), frequentemente confunde-se o pressuposto de racionalidade limitada (uma característica inerente ao agente) com o conceito de incerteza (uma característica imposta pelo ambiente em que a transação ocorre). A distinção está na natureza ambiental. Os limites à racionalidade limitada se referem à resolução de problemas complexos, mesmo em situações de informações perfeitamente conhecidas.

Entretanto, os problemas econômicos complexos requerem dos agentes uma racionalidade, na qual a capacidade cognitiva é limitada, e gera incertezas acerca do ambiente em que estão envolvidos.

\subsection{ESPECIFICIDADE DOS ATIVOS}

A especificidade dos ativos exerce papel fundamental na escolha de uma determinada estrutura de governança. Essa especificidade indica os valores investidos pelas partes em ativos específicos, bem como quanto os agentes poderão perder caso haja ruptura contratual (ZYLBERSZTAJN, 2005). Por isso, à medida que aumenta a especificidade dos ativos, a balança se inclina em favor de uma organização interna da produção, via contratual ou hierárquica. Se a especificidade dos ativos não é tão significativa, dependendo da transação, ela poderia ser realizada via mercado.

Nos processos de produção e comercialização de produtos, existem ativos produtivos que têm especificidades próprias e permitem a produção de outros produtos. Ativos específicos são utilizados na produção e no fluxo físico dos produtos que, por sua vez, possuem suas especificidades próprias. Por fim, existe o produto em si, que possui suas especificidades intrínsecas e extrínsecas, como o caso dos ativos necessários para a segregação da soja ao longo da cadeia logística. Assim, em um sistema produtivo, todos os agentes econômicos possuem seus próprios ativos e produtos específicos (como o 
caso da soja convencional, que passou a ser uma especialidade), os quais são utilizados no processo de efetivação da transação.

Um ativo produtivo é considerado específico quando eleva a produtividade dos recursos empregados, com vistas ao atendimento de determinada transação. A especificidade de um ativo está relacionada ao fator flexibilidade. Quando mais flexível um ativo, maior a probabilidade de uso desse ativo em diferentes atividades, e menor serão as perdas relativas ao investimento, pois os custos poderão ser mais facilmente recuperados. Em outro extremo, quanto menos flexível um ativo, maior a perda de valor, quando o recurso é excluído da transação, e sua utilização é empregada na melhor das alternativas disponíveis.

Por isso, é importante ressaltar que quanto mais específico for o ativo para determinada transação, maior importância deve ser dada aos contratos, que servirão de salvaguardas para uma possível perda futura, na hipótese de uma ruptura contratual onde haja investimentos em ativos específicos para que a transação seja realizada. Isso ocorre no caso dos ativos necessários para a segregação da soja, que são necessários para a oferta de um produto livre de transgênicos, o qual também passa a ser um produto específico.

Os ativos apresentam categorias de especificidade distintas, (WILLIAMSON, 1999), os quais podem ser classificados como segue:

a) Especificidade de Ativo Locacional: os ativos envolvidos possuem restrições locacionais, devido às particularidades dos modais utilizados na transação, ou seja, os ativos são imóveis e seu descolamento necessita de elevados custos. No caso da cadeia logística da soja, essa especificidade é relevante, pois caso o produtor consiga fazer a segregação da soja em sua fazenda, e não haja compradores que paguem o prêmio por essa soja em sua região, ele deverá enviá-la para outro local mais distante que faça esse pagamento, aumentando, assim, sua especificidade locacional.

b) Especificidade de Ativo Temporal: para certos produtos, o tempo é um fator essencial de valor ou de eficiência em determinados processos produtivos. O tempo de efetivação da transação é primordial para que alguns produtos não pereçam ou percam a qualidade. No caso da soja, esse tipo de ativo não é relevante, pois apresenta especificidade 
temporal baixa, uma vez que o produto pode ser armazenado por um longo período sem perder qualidade.

c) Especificidade de Ativo Dedicado: essa especificidade se refere aos aportes de investimentos em ativos, por parte de um agente, com o propósito exclusivo de aumentar a capacidade de oferta, com vistas a atender a quantidade demandada de outro agente. Caso o contrato se interrompa, o agente fornecedor ficará com excesso na capacidade de produção, ou, ao contrário, com uma maior capacidade instalada ociosa. Ou seja, quando uma ou ambas as partes investem em equipamentos e maquinário, cujas características físicas são específicas para o propósito da relação e possuem baixo valor de uso alternativo (NOGUEIRA JUNIOR; TSUNECHIRO, 2005). Para a segregação da soja ao longo da cadeia logística, é necessário investimento em alguns ativos dedicados para que se consiga êxito na separação do produto. Alguns destes ativos serão trabalhados na análise dos resultados dessa pesquisa.

d) Especificidade de Ativos Humanos: essa especificidade está relacionada aos investimentos em recursos humanos (qualificação de pessoal), diretamente ou indiretamente comprometidos nas transações. A realização de um processo de aprendizagem contínua torna o capital humano dotado de habilidades específicas. No caso da cadeia analisada, essa especificidade também assume papel importante, uma vez que é necessário um processo de aprendizagem contínua com os funcionários das empresas que decidem pela segregação para lidar com os possíveis problemas de contaminação que possam emergir ao longo da cadeia. Em vista disso, é necessário tomar cuidado em todos os processos da cadeia logística da soja, desde o momento da compra da semente até a colocação do produto no navio para exportação.

e) Especificidade tecnológica: diz respeito à utilização de tecnologias específicas, como elaboração e aplicação de processos tecnológicos específicos, cuja realocação é custosa. Ela é relevante para o presente estudo, pois são necessários processos específicos que envolvem tecnologia para se conseguir fazer a segregação ao longo da cadeia.

f) Especificidade mercadológica ou especificidade de marca: esta está relacionada à construção de um nome, de uma marca, de uma reputação em um determinado mercado, do esforço de relações públicas com a comunidade, com a imprensa, no 
desenvolvimento de embalagens (NAVES, 2007). A soja convencional é vista pelos mercados que a demandam como de alta qualidade, configurando-se em uma marca a ser zelada.

Trabalhada a revisão de literatura sobre a NEI/ECT, o próximo capítulo da tese versa sobre o levantamento bibliográfico da literatura especializada sobre da Cadeia Logística da Soja. 


\section{CADEIA LOGÍSTICA DA SOJA}

\subsection{ASPECTOS GERAIS}

A cadeia logística é o canal de movimento do produto ao longo do processo industrial e agroindustrial até os clientes, mas pode-se dizer simplesmente que é a sucessão de várias operações, envolvendo o manuseio, movimentações, transporte e armazenagens pelas quais o produto passa, desde que é matéria-prima até chegar ao consumidor final.

As decisões sobre estratégias logísticas referem-se à definição do arranjo entre os diferentes componentes logísticos: estrutura de instalações; processamento de pedidos; manutenção de informação; transporte; manutenção de estoques; armazenagem e manuseio. Estas decisões são baseadas em análise de balanceamento entre diferentes alternativas (trade-off), para busca de menor custo total (MARTINS et al., 2001).

No âmbito da logística, os contratos podem ser um forte alicerce para ajudar na não contaminação do produto ao longo da cadeia, responsabilizando aquele agente que contaminar o produto, fazendo-o arcar com os custos dos royalties e dos prêmios.

Esses assuntos serão tratados neste capítulo com um enfoque sistêmico sobre a problemática que cerca a cadeia logística da soja após o advento dos transgênicos. Foi feito um levantamento do referencial teórico de autores que trabalham com os problemas da contaminação das cadeias de grãos, bem como as estratégias que os agentes utilizam na tentativa de garantir a segregação e a oferta de produtos livre de transgênicos. Foi feito também o levantamento de como a Cadeia Logística da Soja está estruturada, para se ter uma visão holística de todos os processos, ajudando na compreensão e análise do problema proposto pela presente tese.

\subsection{LOGÍSTICA E A CADEIA DA SOJA NO BRASIL}

A logística envolve a gestão do processamento de pedidos, os estoques, os transportes e a combinação de armazenamento, manuseio de materiais e embalagem, todos intimamente integrados e interligados. O objetivo da logística é apoiar as necessidades 
operacionais de compras, produção, e atendimento às expectativas do cliente (BOWERSOX, CLOSS; COOPER, 2006).

A Figura 3.1 mostra as atividades primárias da logística, o que foi definido por Ballou (1993) como ciclo crítico de atividades logísticas, pois estas três atividades são centrais para cumprir a missão logística de prover serviço e disponibilizar produtos para os clientes quando e onde eles quiserem.

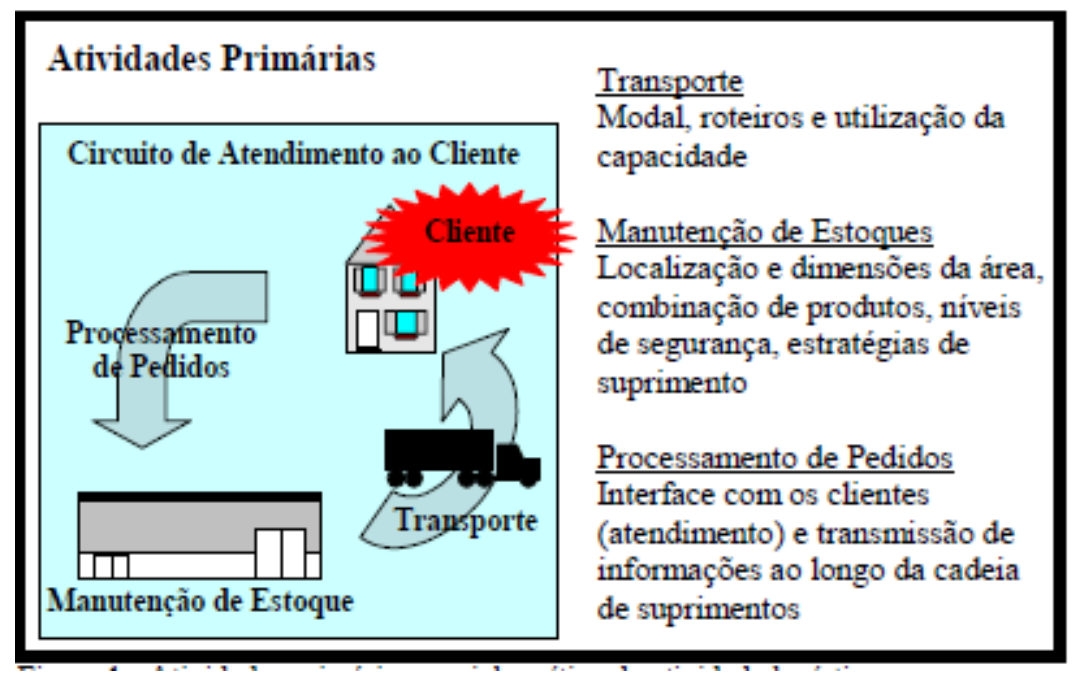

Figura 3.1: Atividades primárias no ciclo crítico de atividade logística Fonte: Adaptado de Ballou (1993)

A movimentação de produtos homogêneos e padronizados mostrou-se como uma importante estratégia do agronegócio para garantir ganhos de escala e facilitar a logística. Contudo, nota-se o crescimento da demanda por grãos diferenciados, tais como os grãos com elevados teores de proteína, com rendimento industrial superior ou com propriedades nutracêuticas (SILVEIRA; OLIVEIRA, 2013; WILKINSON; PESSANHA, 2005). Essa demanda também parece estar delineada para a soja GMO FREE, uma vez que há países interessados em sua aquisição, e o fazem certamente por serem reticentes aos problemas que o consumo de soja transgênica poderá trazer para a saúde humana no futuro. Isso faz com que a logística para esse tipo de produto tenha que passar por algumas adaptações a fim de conseguir entregar um produto de qualidade aos consumidores que a desejarem.

De acordo com Ballou (2006), o transporte representa o elemento mais importante da logística. Com um sistema de transportes precariamente desenvolvido, a extensão do 
mercado fica limitada àquelas áreas imediatamente próximas ao ponto de produção. Complementa Keedi (2001), dizendo que para a criação e desenvolvimento da logística adequada é fundamental o conhecimento dos vários modais de transporte, bem como as cargas adequadas a cada um deles.

Dos cinco modais de transporte existentes apenas três são utilizados no escoamento da soja (rodoviário, ferroviário e aquaviário/hidroviário). O modal dutoviário não é utilizado devido às características físicas do produto, enquanto que o modal aéreo é extremamente caro para o transporte de commodities. Segundo Batalha (2009), o sistema de transporte é especialmente relevante aos produtos agroindustriais (como a soja), devido à alta relação peso-valor que frequentemente caracteriza esses produtos.

De acordo com Hijjar (2007), os modais tipicamente mais eficientes para exportação da soja produzida no Brasil (grandes volumes, longas distâncias e valor agregado relativamente baixo) são as ferrovias e hidrovias. Tais modais, embora exijam um maior tempo de transporte, têm capacidade bem mais elevada e, quando disponíveis, podem trazer economia de custos e redução de perdas. O papel do modal rodoviário, por sua vez, seria de atuação nas "pontas", levando os grãos da lavoura até os terminais ferroviários ou hidroviários.

Segundo Ballou (2001), além das atividades primárias que ocorrem em todo o canal logístico, os processos logísticos são compostos por atividades de suporte, que embora possam ser tão críticas quanto as atividades primárias, em algumas circunstâncias são consideradas como contribuintes para a realização dos processos logísticos. Entre elas, pode-se destacar a armazenagem, manuseio de materiais, embalagem de proteção, aquisição, programação do produto e manutenção da informação. A seguir são detalhadas algumas dessas atividades, segundo definições de Ballou (2001).

Armazenagem: esta atividade envolve acondicionamento e movimentação de bens e a administração do espaço necessário para manter estoques. Isso envolve dimensionamento de área, arranjo físico, recuperação do estoque, projeto de docas ou baias de atracação e configuração do armazém. 
Manuseio de Materiais: está associada com a armazenagem e apoio à manutenção de estoques, e diz respeito à movimentação do produto no local de estocagem. São problemas importantes: seleção do equipamento de movimentação, procedimentos para formação de pedidos e balanceamento da carga de trabalho.

Embalagem e Proteção: a embalagem do produto deve garantir movimentações sem quebra, dimensões adequadas de empacotamento que possibilitem o manuseio ergonômico, além de otimizar a utilização de espaço na armazenagem e no transporte.

Aquisição: é a atividade que deixa o produto disponível para o sistema logístico. Trata da seleção das fontes de suprimento, das quantidades a serem adquiridas, da programação das compras e da forma pela qual o produto é comprado.

Programação do Produto: a atividade lida com a distribuição (fluxo de saída), e trata das quantidades agregadas que devem ser produzidas, bem como onde e quando devem ser fabricadas, ou seja, em que sequência e tempo de produção.

Manutenção de Informação: é essencial para o correto planejamento e controle logístico. Manter uma base de dados que possibilite a geração de informações importantes - por exemplo, localização dos clientes, volumes de vendas, padrões de entrega e níveis dos estoques -, as quais permitam apoiar a administração eficiente das atividades primárias e de suporte.

Para melhor caracterização da importância que as funções logísticas assumem dentro das empresas, é apresentado na Figura 3.2 o relacionamento das diversas atividades da logística primárias/suporte e o nível de serviço, que é importante para que as empresas se diferenciem em um mercado tão competitivo. 


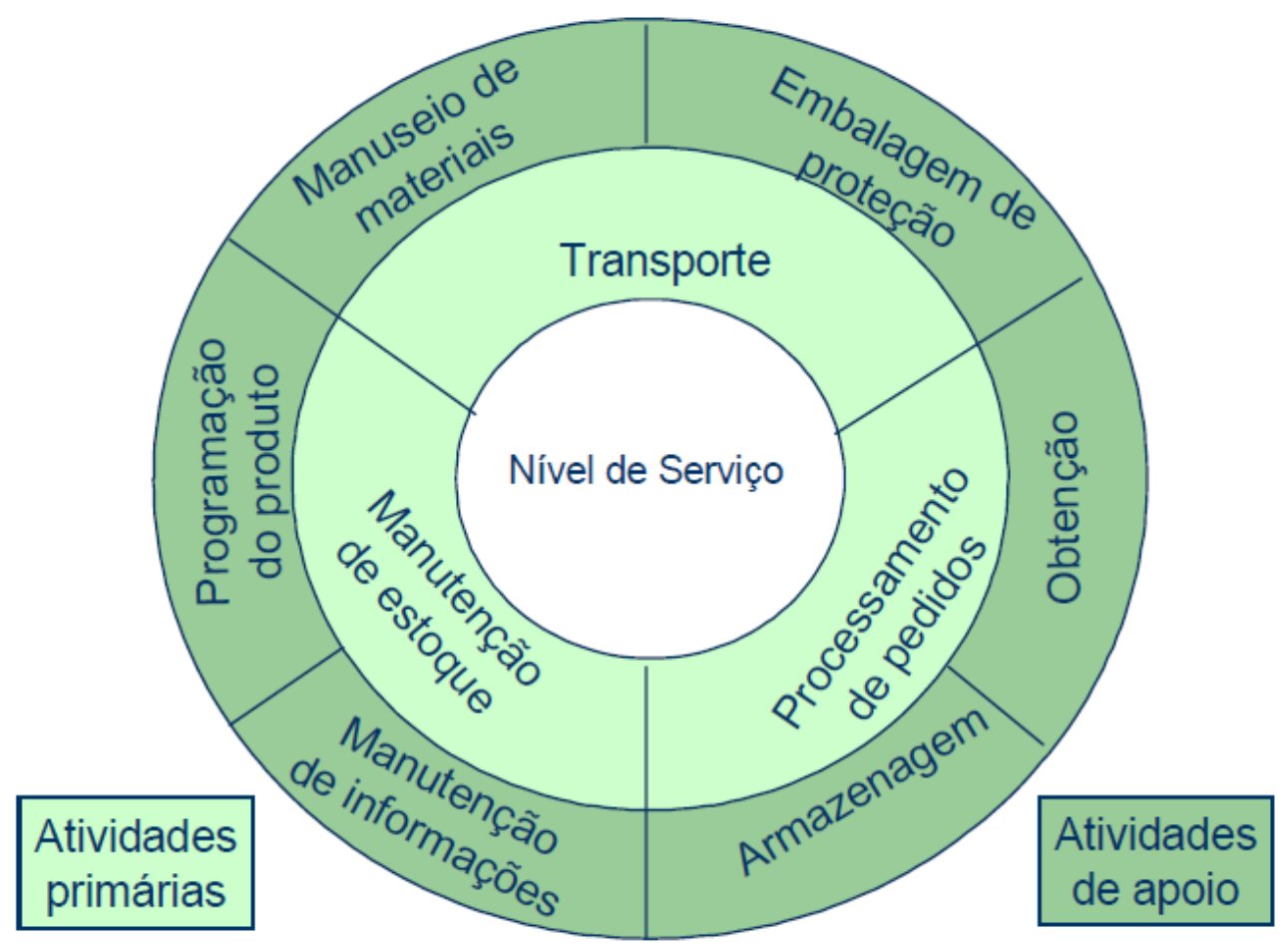

Figura 3.2: Relação entre atividades logísticas primárias e de apoio e o nível de serviço desejado

Fonte: Novaes (1993)

Visando a elucidar melhor os processos logísticos que foram relatados anteriormente, é mostrada na Tabela 3.1 uma relação das atividades primárias e de apoio relacionadas aos problemas que a cadeia logística da soja vem sofrendo após o advento dos transgênicos.

\section{Tabela 3.1: Relação das atividades primárias e de suporte logístico com a cadeia logística da soja após o advento e a adoção dos transgênicos}

\begin{tabular}{l|l}
\hline \hline \multicolumn{1}{c|}{$\begin{array}{c}\text { Problemas trazidos pelo advento e adoção da } \\
\text { soja transgênica }\end{array}$} & \multicolumn{1}{c}{$\begin{array}{c}\text { Atividades logísticas primárias e de apoio } \\
\text { envolvidas }\end{array}$} \\
\hline $\begin{array}{l}\text { Contaminação da soja convencional pela } \\
\text { transgênica nos vários estágios da cadeia logística }\end{array}$ & $\begin{array}{l}\text { Manuseio de materiais, transporte, armazenagem, } \\
\text { manuseio e transbordo }\end{array}$ \\
\hline Pagamento de royalties & $\begin{array}{l}\text { Manutenção de informações, aquisição e } \\
\text { processamento de pedidos }\end{array}$ \\
\hline $\begin{array}{l}\text { Expectativa de recebimento de preços prêmio para } \\
\text { soja livre de transgênicos }\end{array}$ & Aquisição \\
\hline Necessidade de segregação do produto & Transporte, armazenagem, manuseio e transbordo \\
\hline $\begin{array}{l}\text { Necessidade de investimentos em ativos } \\
\text { específicos para a segregação }\end{array}$ & Transporte, armazenagem e manuseio de materiais \\
\hline $\begin{array}{l}\text { Papel dos contratos para a garantia da não } \\
\text { contaminação }\end{array}$ & Manutenção de informações e aquisição \\
\hline Rastreabilidade & Manutenção da informação \\
\hline \hline
\end{tabular}

Fonte: Elaborado pelo autor (2014) 
Todas essas informações são importantes para melhor compreender como está a cadeia logística da soja após o advento dos transgênicos no Brasil.

\subsubsection{Agentes Envolvidos na Cadeia Logística da Soja no Brasil}

A seguir são apresentadas informações importantes sobre as atividades logísticas desempenhadas por cada agente que faz parte da atual da cadeia logística da soja brasileira. Além destas, são apresentadas outras informações importantes sobre cada agente estudado, o que ajudou a entender melhor a lógica de toda a cadeia.

\subsubsection{Produção de Soja no Brasil}

O produtor rural é uma pessoa física ou jurídica que explora a terra, com fins econômicos ou de subsistência, por meio da agricultura, da pecuária, da silvicultura, do extrativismo sustentável, da aquicultura, além de atividades não agrícolas, respeitadas a função social da terra.

Embora haja registros históricos que apontam para cultivos experimentais de soja na Bahia já em 1882, a introdução da soja no Brasil tem o ano de 1901 como marco principal: é quando começam os cultivos na Estação Agropecuária de Campinas e a distribuição de sementes para produtores paulistas. $\mathrm{O}$ grão começa a ser mais facilmente encontrado no país a partir da intensificação da imigração japonesa, por volta de 1908. Em 1914, é oficialmente introduzida no Rio Grande do Sul - estado que apresenta condições climáticas similares às das regiões produtoras nos Estados Unidos. (APROSOJA, 2014).

A expansão da soja no Brasil começa com mais ênfase nos anos 1970, quando a indústria de óleo começa a ser ampliada. $\mathrm{O}$ aumento da demanda internacional pelo grão é outro fator que contribui para o início dos trabalhos comerciais e em grande escala da sojicultora (APROSOJA, 2014).

O Brasil é o segundo país na produção e processamento mundial de soja, sendo também o segundo maior exportador de grão, óleo e farelo de soja (APROSOJA, 2014). Estimase que a cadeia da soja reúna no país mais de 243 mil produtores, e um mercado de 1,4 
milhões de empregos. Atualmente, $70 \%$ da produção de grão, óleo e farelo de soja são exportados (APROSOJA, 2014).

Atualmente, uma das grandes dificuldades para muitos produtores trabalharem com a soja livre de transgênicos está diretamente relacionada à falta de ativos para fazer a segregação da soja, emblematicamente a falta de armazéns em seus estabelecimentos, ou armazéns públicos que permitam fazer a segregação do produto.

As atividades logísticas desempenhadas pelos produtores são: manuseio de materiais, obtenção, armazenagem, manutenção da informação, programação do produto, manutenção de estoque, processamento de pedidos e transporte.

\subsubsection{Armazenagem da Soja no Brasil}

O armazenador/processador é uma empresa receptora de grãos que cumpre a função específica de "originadores ${ }^{17}$ ", como também empresas processadoras/esmagadoras propriamente ditas.

O armazenamento é uma atividade essencial para a redução das perdas agrícolas e para a conservação dos grãos de soja. Segundo Sasseron (1995), a armazenagem é a atividade que auxilia na conservação dos produtos, de modo a manter em ambiente natural a integridade qualitativa e quantitativa dos grãos de soja.

Segundo Sasseron (1995), as funções da armazenagem estão classificadas em intrínsecas e extrínsecas. As funções intrínsecas da armazenagem são: conservação da produção; redução de perdas e estocagem dos excedentes agrícolas. As funções extrínsecas estão relacionadas com o transporte e a comercialização da produção agrícola, são elas: racionalizar o transporte; coleta de safra; suporte de comercialização; formação de estoques reguladores; e auxilio às políticas governamentais.

\footnotetext{
${ }^{17}$ Composto por tradings, cooperativas, corretores e armazenadores/processadores, em contato direto com os produtores, no processo de aquisição, armazenagem e distribuição de matérias-primas (LEITÃO, 2009).
} 
Os armazéns estão presentes nos mais diversos elos de escoamento da soja para exportação, pois durante o processo de comercialização, por exemplo, tem que passar por um armazém para a retirada de impurezas e para redução de sua umidade, a fim de conservar o produto e otimizar a utilização do modal de transporte utilizado (FERRARI, 2006).

De acordo com a CONAB (2013), o Brasil conta uma infraestrutura de 13,7 mil unidades armazenadoras, com capacidade estática para estocar cerca de 93,8 milhões de toneladas de grãos. Os armazéns graneleiros representam $75 \%$ dessa capacidade, sendo o restante relativo à capacidade das unidades armazenadoras convencionais. As regiões Sul e Centro-Oeste detêm, respectivamente, $45 \%$ e $33 \%$ da capacidade dos armazéns graneleiros. As regiões Sudeste, Nordeste e Norte representam respectivamente $16 \%$, $4 \%$ e $2 \%$ da capacidade de armazenamento do país.

Para Naves (2007), enquanto há o crescimento da produção agrícola brasileira, a logística para seu escoamento segue caminho contrário. O déficit na área de armazenamento e na infraestrutura de transportes e serviços resulta em um elevado custo logístico. Esse custo pode ser agravado nas situações de contaminação da soja, haja vista que o produtor terá que pagar royalties para a detentora da patente, além de que deve haver investimento em ativos específicos, como a construção de silos para armazenagem de um tipo de soja, aquisição de caminhões para transporte, investimento em pessoal capacitado para cuidar da limpeza dos caminhões, dentre outros.

No entanto, além do déficit na capacidade de armazenamento de produtos agrícolas que, em 2014 chega a 50 milhões de toneladas (MENDEZ, 2014), o que se observa é a falta de armazéns nas áreas de produção. Isso pode agravar ainda mais o problema da contaminação, uma vez que se a soja transgênica for colocada junto à convencional haverá a contaminação. Nessa situação, seria necessário que houvesse dois armazéns, um para colocar a soja transgênica, e outro para colocar a convencional, o que agravaria ainda mais o problema de nossa capacidade estática. As Figuras 3.3 e 3.4 fazem uma comparação da capacidade de armazenamento com a produção do Brasil. 


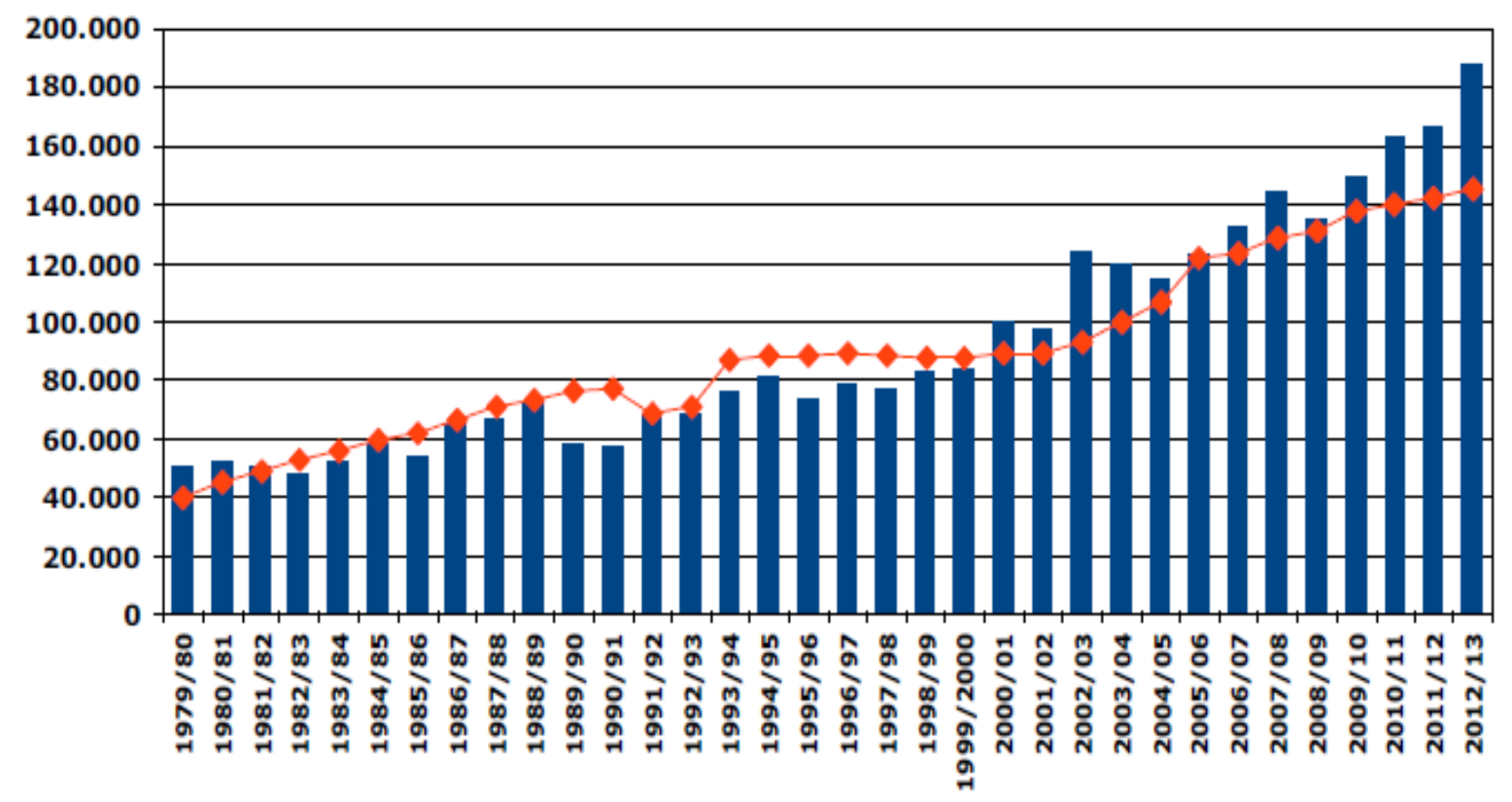

$\square$ PRODUÇÃo em mil/t $\multimap$ CAPACIDADE ESTÁTICA em mil/t

Figura 3.3: Capacidade de armazenagem x Produção do Brasil

Fonte: Conab (2013)

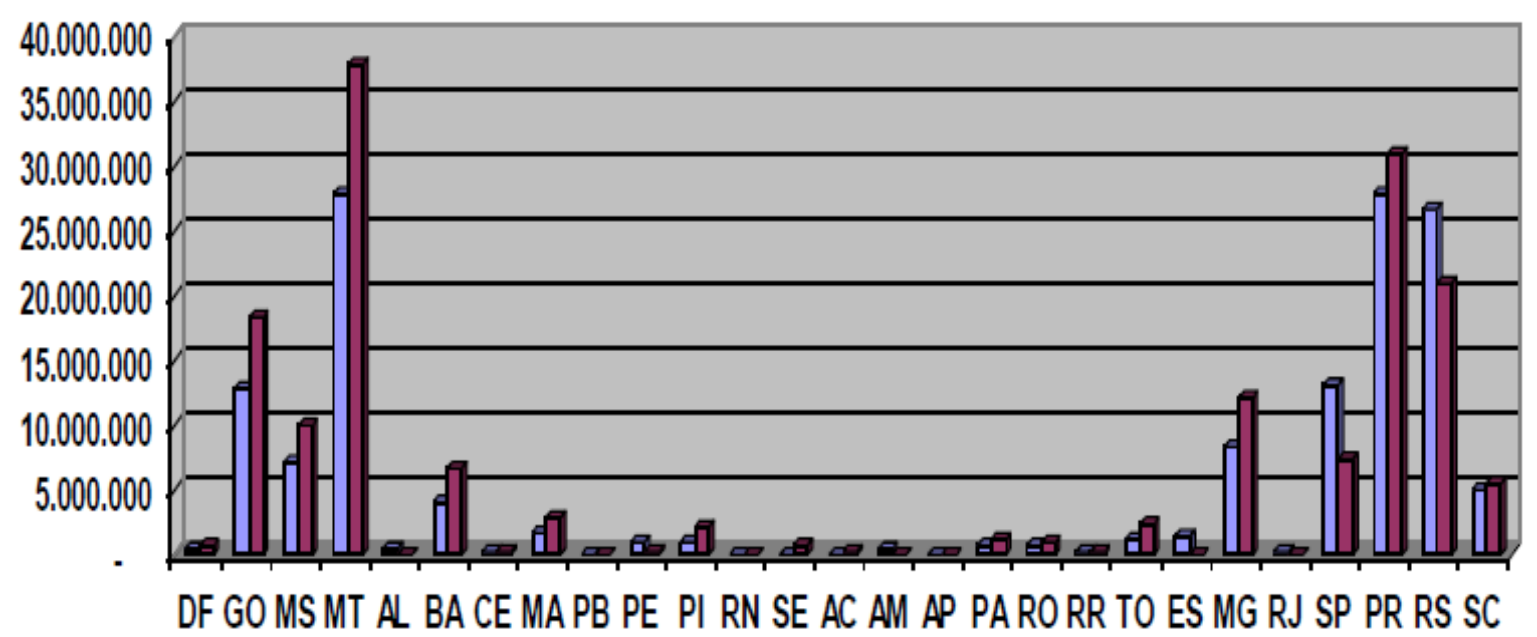

口Cap. Estática (t) QProdução (t)

Figura 3.4: Capacidade de armazenagem por estado x Produção do Brasil

Fonte: Conab (2013)

Segundo a Conab (2013), o mercado de equipamentos para armazenagem de grãos no Brasil deve crescer 25 por cento em 2014, estimulado por programas do governo que facilitam os financiamentos para investimentos por parte dos agricultores. Porém, a capacidade estática de armazenagem no país ainda está longe da recomendada. O país está colhendo, na atual temporada, uma safra de quase 200 milhões de toneladas, com 
silos e armazéns que comportam entre 130 milhões e 150 milhões de toneladas. Os especialistas estimam que um país deva ter capacidade de guardar pelo menos 120 por cento do volume que colhe.

Uma limitação atualmente presente no Brasil diz respeito à falta de infraestrutura de armazenagem para classificação e separação de grandes volumes, com diferentes padrões qualitativos de grãos (ZILBERSTAJN, LAZARRINI; MACHADO FILHO, 1999). Aspecto importante refere-se também à necessidade do estabelecimento de incentivos adequados para que o produtor utilize materiais genéticos em consonância com as demandas da indústria, ou seja, "prêmios" sobre padrões qualitativos específicos, como no caso da soja livre de transgênicos (ZILBERSTAJN, LAZARRINI; MACHADO FILHO, 1999).

As estimativas também demonstram que não haverá capacidade de armazenagem suficiente para uma produção tão elevada, e a necessidade de segregação das sojas, transgênica e convencional, poderá agravar ainda mais esse problema, haja vista que a logística é distinta para cada produto. Isso ocorre, pois quando o produto é armazenado deve ser colocado em armazéns diferentes para que não haja a contaminação (LEITÃO, 2009).

Além dos problemas referentes à capacidade estática, há pesquisas que comprovam o poder que os armazenadores/processadores têm de ditar comportamentos ao longo da cadeia da soja, cobrando dos agentes a montante e a jusante atitudes que lhes irão beneficiar no futuro. Eles fazem valer seus interesses, e, às vezes, não repassam os ganhos advindos da negociação para os demais agentes da cadeia, como é o caso do recebimento do prêmio que muitas vezes não é repassado para os produtores (LEITÃO et al, 2008). O capítulo 5 retornará a essa discussão e mostrará o poder e papel dos armazenadores/processadores, principalmente no que tange à gestão dos contratos para pagamento e recebimento dos prêmios advindos da segregação ao longo da cadeia logística. 


\subsubsection{Transporte Rodoviário da Soja no Brasil}

O transporte rodoviário é o transporte feito por estradas, rodovias, ruas e outras vias pavimentadas ou não, com a intenção de movimentar materiais, pessoas ou animais de um determinado ponto a outro. O transporte rodoviário é realizado em estradas de rodagem por caminhões, carretas e treminhões. É o mais utilizado para o transporte de cargas no Brasil, atingindo praticamente todos os pontos do território nacional, já que desde a década de 1950 as construções de estradas foram mais incentivadas que a construção de outros modais de transporte (LAVORENTI, 2011).

O transporte rodoviário é uma das principais atividades logística da cadeia da soja. Segundo Lavorenti (2011), o transporte de soja é realizado, principalmente, por meio de três modais de transporte: o rodoviário, o ferroviário e o fluvial. Porém, a maior parte da soja é transportada por rodovias, e estas se encontram em mau estado de conservação. Além da má conservação das rodovias, observa-se a obsolescência da frota de caminhões e o congestionamento das rotas para os portos no período de escoamento da safra para exportação (PONTES, CARMO; PORTO, 2009).

$\mathrm{Na}$ cadeia logística em análise, o transportador rodoviário tem o papel de fazer a movimentação da soja desde a fazenda do produtor até sua colocação no porto, e as atividades logísticas desempenhadas por ele são: manuseio de materiais, armazenagem, programação do produto e transporte.

Segundo a Agência Nacional de Transporte Terrestre (ANTT), o transporte rodoviário em sua maioria é realizado por veículos automotores como carros, autocarros e caminhões. Existem cerca de 130 mil empresas de transporte de cargas no Brasil com mais de 1,6 milhões de veículos que oferecem trabalho, diretamente, a pelo menos 5 milhões de pessoas (ANTT, 2014).

Segundo dados da Confederação Nacional do Transporte (CNT), há grande número de prestadores de serviços autônomos (51\% da frota de caminhões brasileira é de autônomos), trabalhando com veículos em estado precário de conservação, e realizando jornadas de trabalho excessivamente longas (CNT, 2013). 
Segundo a CNT (2013), somente um quarto de toda a malha rodoviária federal no Brasil está em boas condições para trafegar. Mesmo os trechos concedidos à iniciativa privada ou sob gestão estadual estão em estado precário. Mais da metade da malha apresenta problemas de pavimentação, como buracos e ondulações. A sinalização defeituosa foi constatada em $65,4 \%$ das rodovias, e $39,8 \%$ das estradas não possuem acostamento.

Segundo Pontes, Carmo e Porto (2009), os principais problemas logísticos das rodovias são: a extensão da malha viária é inadequada para o atendimento da demanda; a insuficiência de veículos para transporte no período de safra, o que faz com que o frete aumente razoavelmente; a infraestrutura rodoviária degradada, com deterioração das condições operacionais, como falta de sinalização, acostamento, pavimentação, dentre outros; e a falta de sistemas modernos para fiscalização e controle da circulação do transporte rodoviário.

A Figura 3.5 apresenta a malha viária utilizada no escoamento da soja para exportação, nos modais rodoviário, ferroviário e fluvial. 


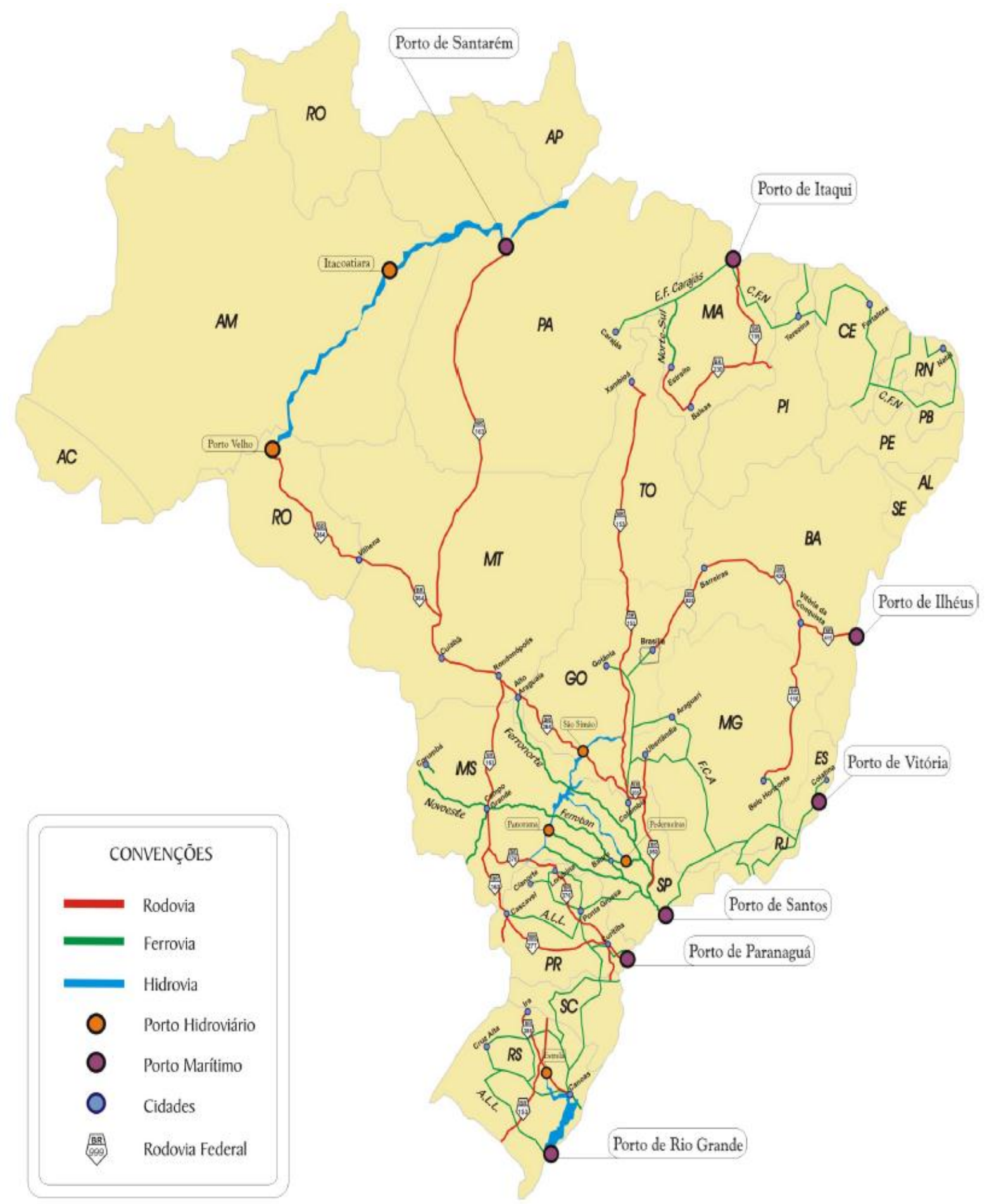

Figura 3.5: Malha viária utilizada no transporte da soja destinada a exportação Fonte: Ojima (2004)

Dados da CNT (2013) mostram que a pavimentação, a sinalização e a geometria das rodovias brasileiras apresentam problemas. 
Sobre a pavimentação, 46,9\% apresentam algum tipo de problema, 43,0\% têm a superfície do pavimento desgastada e $85 \%$ das rodovias sob concessão tiveram classificação ótimo ou bom (CNT, 2013).

A respeito da sinalização, 67,3\% apresentam algum tipo de problema; 78,7\% das rodovias sob gestão pública possuem problemas; $25,2 \%$ não possuem placas de limite de velocidade; $55,8 \%$ possuem pintura da faixa central desgastada ou inexistente; e 63,2\% não possuem faixas laterais ou a pintura está desgastada (CNT, 2013).

Sobre a geometria, 77,9\% apresentam algum tipo de problema, pistas simples de mão dupla correspondem a $88 \%$ da extensão pesquisada, $40,5 \%$ não possuem acostamento e em 56,7\%, onde há ocorrência de curvas perigosas, não há placas de advertências e nem defensas completas (CNT, 2013).

Além disso, a CNT (2013) mostra que, em 2013, houve 250 ocorrências consideradas como pontos críticos (quedas de barreira, pontes caídas, erosões, buracos grandes), trazendo custos adicionais de operação, devido à possiblidade de danos severos aos veículos. Fator que aumenta o tempo de viagem ou a elevação da despesa com combustíveis. Em 2012, foram 221 ocorrências (CNT, 2013).

Dados da CNT (2013) mostram que apenas 10,2\% das rodovias brasileiras se encontram em ótimo estado, $26 \%$ em bom estado, 34,4\% regular, $21,4 \%$ ruim e $8 \%$ péssimo.

Todos os dados demonstram a grande dificuldade e barreiras que há no transporte rodoviário da soja brasileira. Este problema se agrava ainda mais pelo fato deste tipo de transporte ser o mais utilizado para fazer a movimentação da soja ao longo da cadeia logística da soja. Além disso, há o problema da limpeza dos caminhões, a qual deve ser realizada antes de qualquer carregamento de soja livre de transgênicos, a fim de que não haja o risco de contaminação.

\subsubsection{Transporte Ferroviário da Soja no Brasil}

O transporte ferroviário é a transferência de pessoas ou bens, entre dois locais geograficamente separados, efetuados por um comboio, automotora ou outro veículo 
semelhante. Na cadeia logística da soja, o transportador ferroviário tem o papel de fazer a movimentação por comboio do armazenador/processador que faz o processamento da soja até o porto. As atividades logísticas desempenhadas pelo transporte ferroviário na cadeia logística da soja são: manuseio de materiais, armazenagem, programação do produto e transporte.

O modal ferroviário possui alta capacidade de transporte de carga e é mais adequado quando utilizado como transporte em grandes distâncias, não sendo viável para pequenos percursos, nos quais o modal rodoviário é mais adequado (LAVORENTI, 2011).

De acordo com Pontes, Carmo e Porto (2009), a interiorização do plantio de soja em larga escala é responsável por uma atenção específica sobre as questões de infraestrutura logística para a exportação da soja brasileira. Segundo os autores, os principais problemas logísticos das ferrovias são: a malha viária é pouco extensa para o atendimento da demanda, além de se encontrar mal conservada; a integração operacional entre concessionários é deficiente, pois há diferença de bitola entre as malhas; os vagões e locomotivas estão com idade média elevada e em quantidade insuficiente; e há invasão da faixa de domínio das ferrovias nos centros urbanos e nos acessos aos portos, tornando o tempo de trânsito muito elevado.

Com relação às ferrovias, a CNT (2011) mostra que o processo de desestatização trouxe ganhos de desempenho operacional, a saber: aumento da produtividade do pessoal, das locomotivas e dos vagões; redução dos tempos de imobilização; redução do índice de acidentes; redução do custo de produção; crescimento da produção ferroviária; aumento dos investimentos.

As Figuras 3.6 e 3.7 mostram o atual sistema ferroviário e os seus principais corredores no Brasil. 


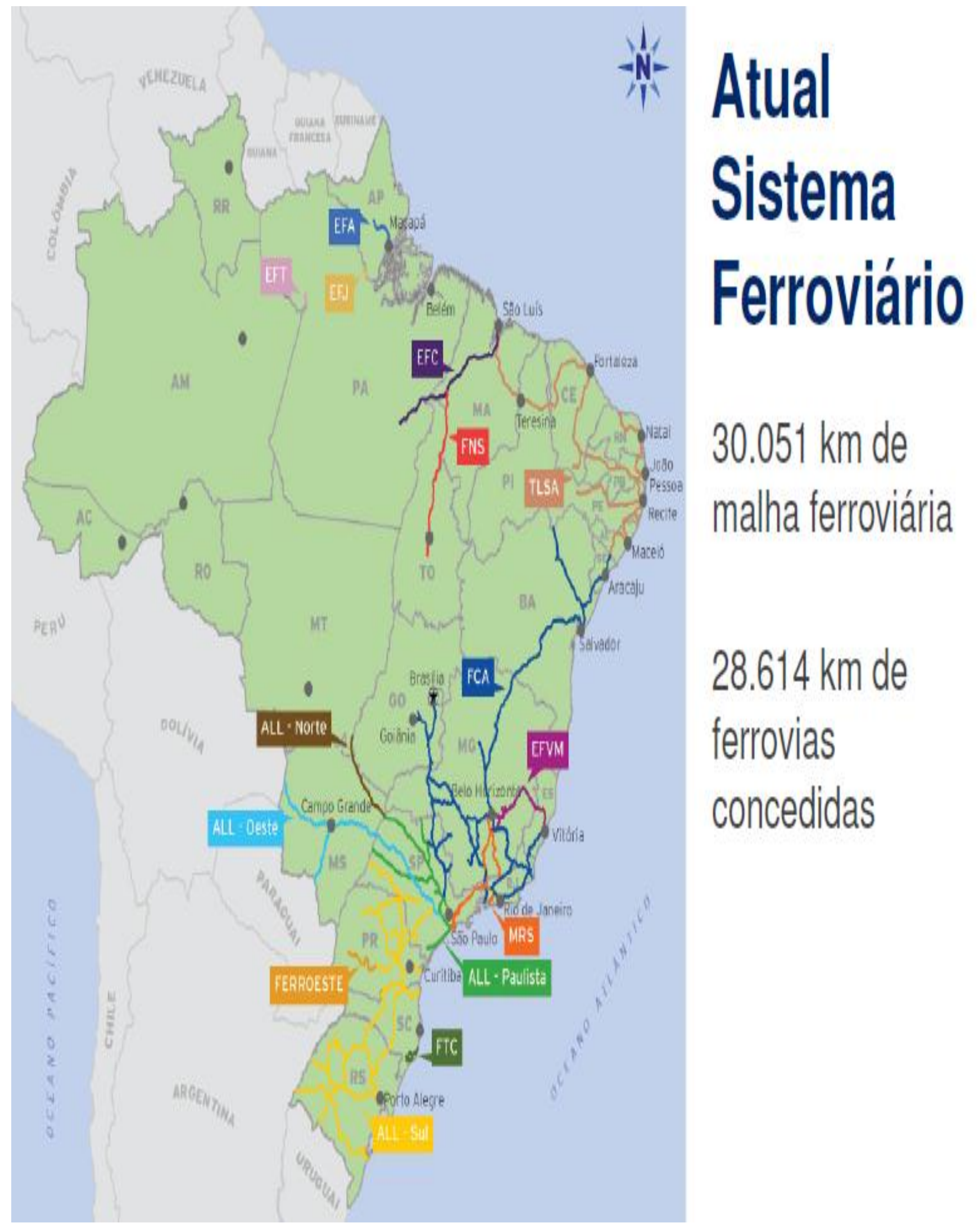

Figura 3.6: Atual sistema ferroviário brasileiro Fonte: CNT (2011) 


\section{Corredor Sáo Lús}

2. Corredor Intraregognal Nordeste

3. Corredor Vitionia

4. Corredor Centro-Oesse- Sáa Paulo

5. Corredor Sáo Paulo - Nordessete

6. Corredor Rio de Vaneiro - Belo Horizonte

7. Corredor Rio de Janeiro · Sä́ Paulo

8. Corredor Santios (bitola largal

9. Corredor Coumbá. Santos (bitolasstrita)

10. Corredor Paranagúá

11. Corredor Sáo Franciso do Sul

12. Corredor Fio Grande

13. Corredor Imbititba

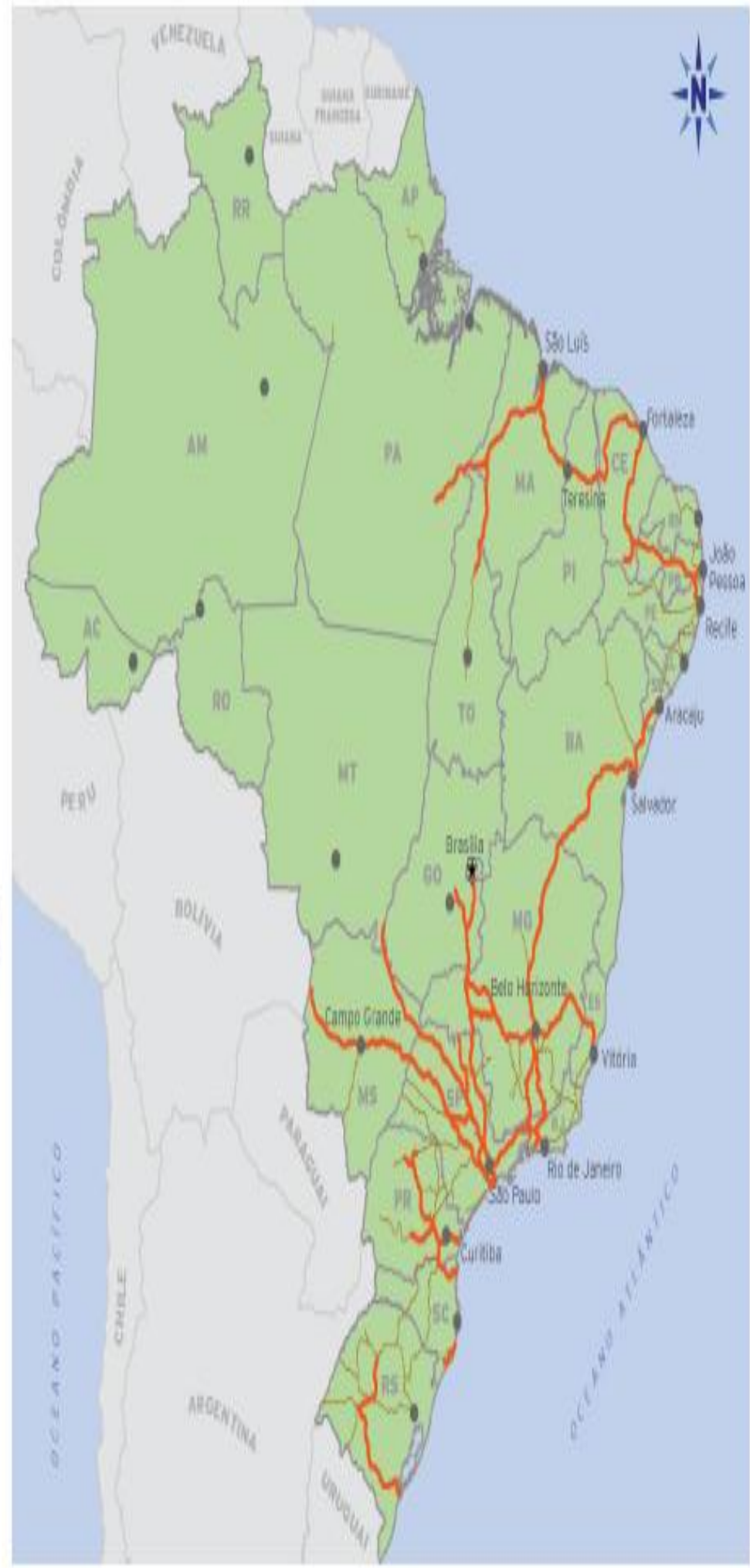

Figura 3.7: Principais corredores ferroviários brasileiros

Fonte: CNT (2011)

Em relação aos aspectos operacionais, dados da CNT (2011) também mostram que $65,9 \%$ dos clientes usam terminais próprios; $52,5 \%$ dos clientes consideram a 
infraestrutura dos terminais das ferrovias adequada; 45,6\% acham que os serviços oferecidos nos terminais das ferrovias são insuficientes; $75,2 \%$ consideram satisfatório o tempo de carga no terminal; 77,4\% consideram satisfatório o tempo de descarga no terminal; e 41,7\% dos clientes consideram boa a conservação e limpeza dos vagões.

Com relação aos serviços prestados pelos corredores ferroviários, 44,5\% dos clientes consideram bom o serviço de coleta e entrega de mercadorias; 73,3\% informaram que não há disponibilidade de serviço de coleta e entrega de mercadorias próprias das ferrovias; $51,8 \%$ dos clientes consideram a programação de viagens ofertadas como adequada; $32,3 \%$ disseram que os prazos sempre são cumpridos; 56,3\% consideram boa a segurança e integridade das cargas; $71,3 \%$ afirmaram que a comunicação com a concessionária é adequada; e 58\% disseram que as informações disponibilizadas para a empresa é adequada (CNT, 2011).

Os dados da CNT (2011) ainda mostram que os principais entraves para a utilização da ferrovia no Brasil são o custo do frete, a falta de disponibilidade de vagões especializados e a confiabilidade dos prazos. Para o transporte da soja livre de transgênicos, é necessária a limpeza dos vagões que farão o transporte da soja de seu ponto de origem até seu destino, para que não haja problemas de contaminação por grãos transgênicos remanescentes.

\subsubsection{Operadores Portuários da Soja no Brasil}

O operador portuário é uma pessoa jurídica pré-qualificada para a movimentação e a armazenagem de mercadorias destinadas ou provenientes de transporte aquaviário, realizadas no porto organizado (LAVORENTI, 2011). As atividades logísticas desempenhadas por eles são: o manuseio de materiais, a armazenagem, a manutenção da informação, a programação do produto e o transporte.

Para Lavorenti (2011), os portos de Santos/SP, Manaus/AM, Vitória/ES, Paranaguá/PR, Santarém/PA e São Francisco do Sul/SC são responsáveis pelo escoamento de $99 \%$ da produção da commodity mato-grossense, e grandes responsáveis pelo escoamento da soja brasileira. 
Segundo dados da CNT (2012), o Brasil possui 34 portos públicos, como pode ser observado na Figura 3.8.

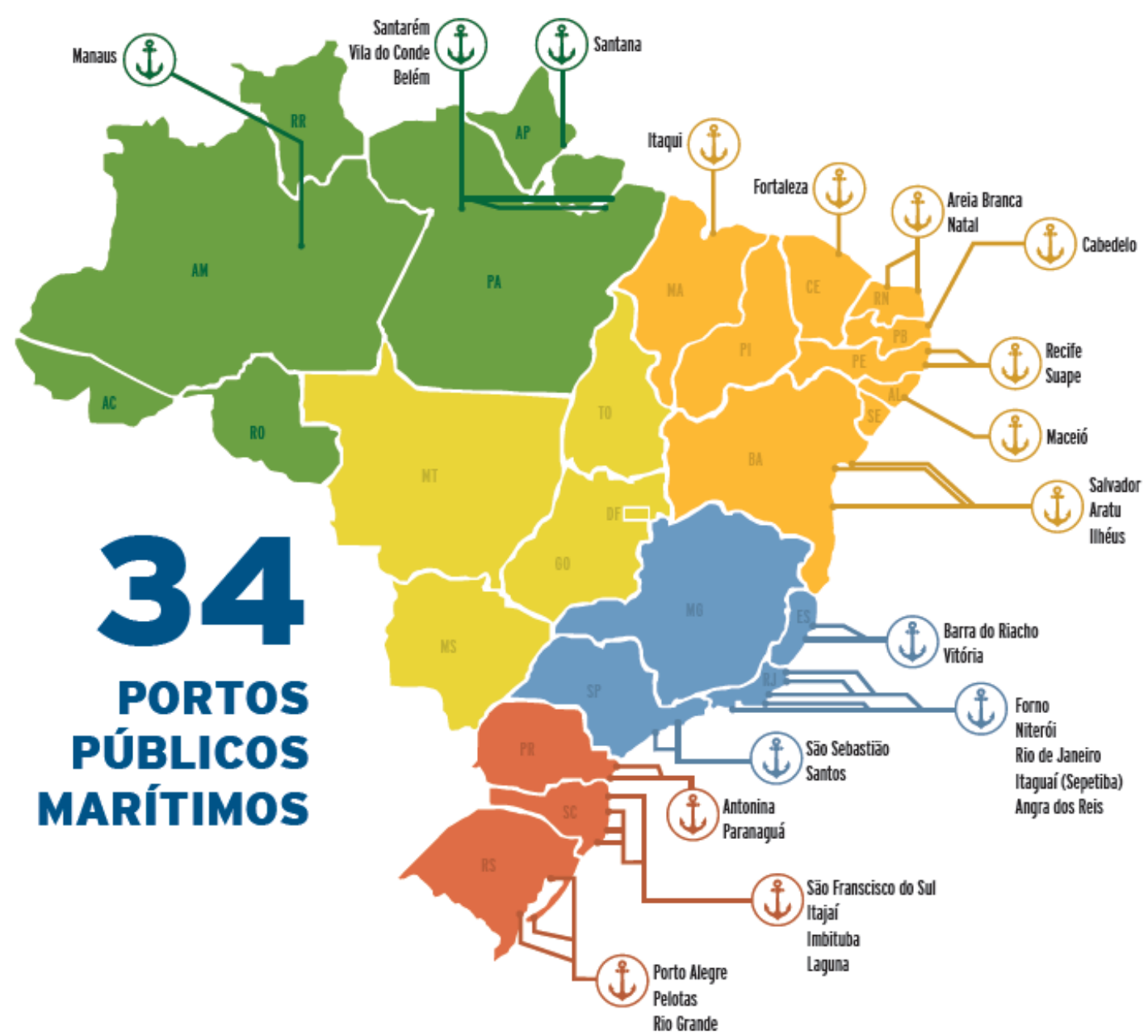

Figura 3.8: Portos públicos marítimos

Fonte: CNT (2012)

A Secretaria de Portos da Presidência da República (SEP/PR) é responsável pela formulação de políticas e pela execução de medidas, programas e projetos de apoio ao desenvolvimento da infraestrutura dos portos marítimos. Dos 35 portos públicos (34 marítimos e 1 fluvial) sob gestão da SEP/PR, 14 encontram-se delegados, concedidos ou têm sua operação autorizada aos governos estaduais e municipais. Os outros 23 marítimos são administrados diretamente pelas Companhias Docas, sociedades de economia mista, que têm como acionista majoritário o Governo Federal e, portanto, estão diretamente vinculadas à Secretaria de Portos (SECRETARIA DE PORTOS, 2014). 
Os principais problemas do setor portuário são o excesso de tributação e tarifação, elevado custo unitário, acesso terrestre deficiente, elevado custo de mão de obra portuária e o excesso da burocracia (CNT, 2012).

A disponibilidade de espaço físico da retroárea (espaço operacional de um porto à ré do cais de atracação, sendo usualmente alfandegada e contendo pátios e armazéns) é inadequada (CNT, 2012). A pesquisa da CNT (2012) constatou também que o tempo de carga e descarga nos terminais públicos é lento.

Segundo Pontes, Carmo e Porto (2009), os principais problemas do complexo portuário brasileiro são os grandes congestionamentos, tanto em terra quanto no mar. Exemplo disso são as filas de caminhões que se formam nos portos para descarregamento e o tempo de espera de navios.

A precária infraestrutura dos portos também é um problema para os exportadores brasileiros de soja em grão. Os principais problemas são a falta de armazéns e os estacionamentos para caminhões. Os resultados desses problemas são filas intermináveis, atrasos nos embarques e prejuízos. Além de todas essas barreiras, agora também há falta de navios. A demanda de espaço nos cargueiros chega a ser $30 \%$ maior que a oferta. A grande procura fez subir o aluguel das embarcações, o que pesa no custo dos fretes (PONTES, CARMO; PORTO, 2009)

Para acabar com os problemas das filas, desde fevereiro de 2014, o porto de Santos está trabalhando com um esquema de agendamento dos caminhões que transportam a safra. Agora, os caminhões que levam soja para a zona portuária precisam passar por um agendamento eletrônico, o que reduz drasticamente o tempo de carga e descarga. Esse agendamento também está em fase de testes no porto de Paranaguá.

Com uma costa de 8,5 mil quilômetros navegáveis, o complexo portuário brasileiro movimentou, em 2013, 931 milhões de toneladas de carga bruta, apresentando um crescimento de 2,9\% em relação a 2012. Sozinho, o setor portuário é responsável por mais de $90 \%$ das exportações do país. Dessa movimentação, 338 milhões de toneladas 
(36\%) foram realizadas pelos Portos Organizados e 593 milhões (64\%) pelos Terminais de Uso Privado (TUPs) (SECRETARIA DE PORTOS, 2014).

Segundo Fleury (2014), os portos enfrentam uma série de problemas que prejudicam as exportações e a competitividade brasileira no mercado mundial. A pouca disponibilidade de armazenagem, a baixa quantidade de píeres e a falta de coordenação entre o que é enviado e o que pode ser recebido pelo porto são os principais problemas durante o escoamento da safra da soja em grão para exportação.

Todos os problemas relatados anteriormente se agravam ainda mais pelo fato de o Brasil ser o maior exportador mundial de soja, como mostra a Figura 3.9.

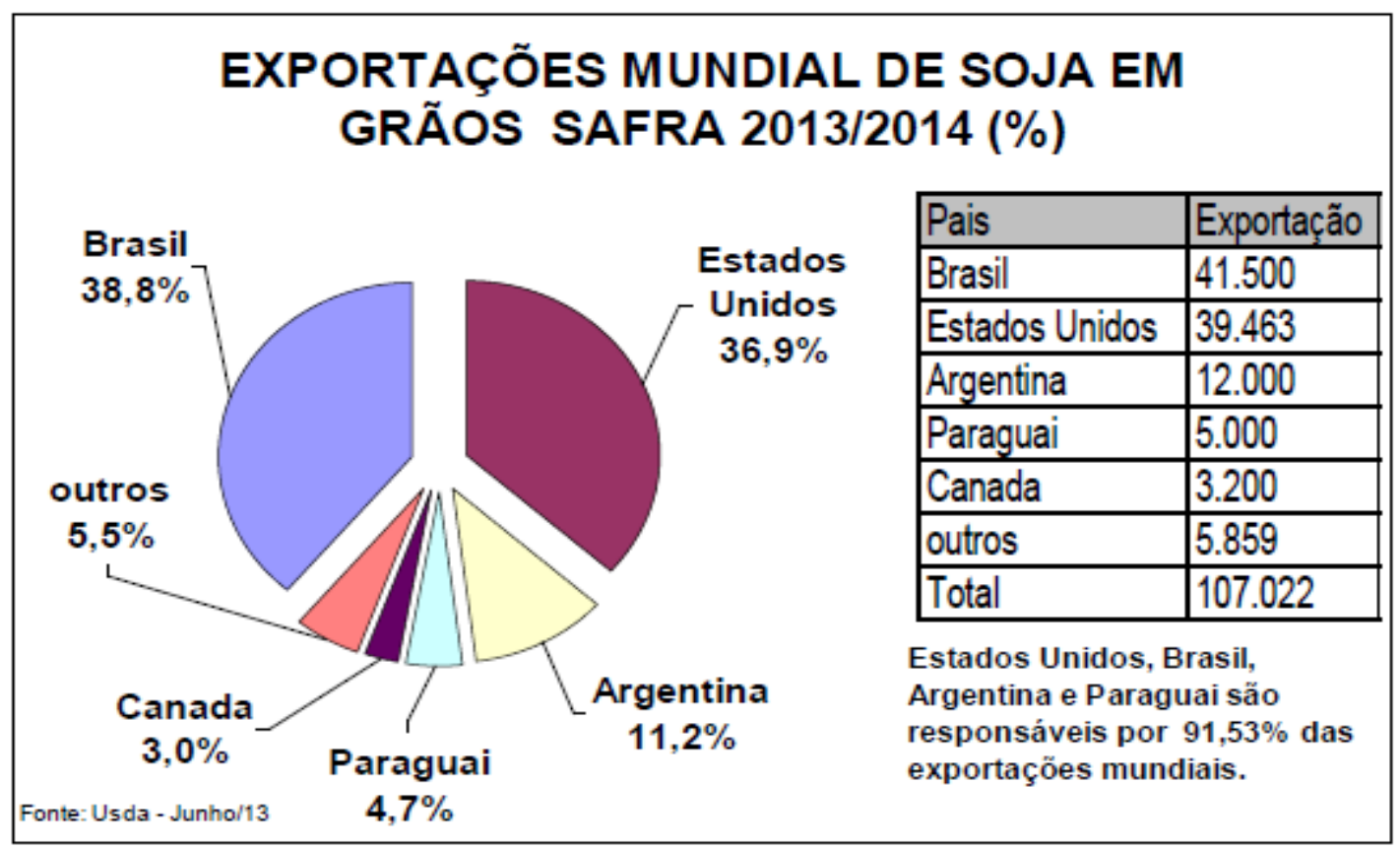

Figura 3.9: Exportação mundial de soja em grãos safra 2013/2014 Fonte: CONAB (2014 apud USDA, 2014).

Já há estimativas da CONAB mostrando que na safra 2013/14 o Brasil, além de ser o maior exportador, também se tornará o maior produtor mundial de soja, superando os EUA, com 190 milhões de toneladas de soja produzida (CONAB, 2014).

As Tabelas 3.2, 3.3, 3.4, 3.5, 3.6 e 3.7 mostram os dados de movimentação, evolução e destino das exportações da soja e seus derivados. Mostram também os principais países importadores do farelo de soja, óleo de soja e da soja em grãos em Janeiro e Fevereiro 
de 2014. Os meses de Janeiro e Fevereiro foram escolhidos por serem os períodos com dados mais recentes sobre a exportação. A evolução do volume exportado varia ao longo do ano; porém, isso não foi discutido no presente trabalho.

Tabela 3.2: Evolução das exportações de farelo de soja por porto em 2014

\begin{tabular}{c|c|c|c}
\hline \hline Período & Porto & US\$ FOB & Volume (Ton) \\
\hline JANEIRO/FEVEREIRO & PORTO DE PARANAGUÁ - PR & 243.034 .195 & 467.278 \\
\hline & SANTOS - SP & 199.595 .046 & 343.172 \\
\hline & PORTO DE RIO GRANDE - RS & 163.740 .691 & 317.191 \\
\hline & SALVADOR - PORTO - BA & 14.597 .785 & 28.995 \\
\hline & VITÓRIA - PORTO - ES & 12.154 .199 & 25.660 \\
\hline Total Acumulado & & $\mathbf{6 3 3 . 1 2 1 . 9 1 6}$ & $\mathbf{1 . 1 8 2 . 2 9 6}$ \\
\hline \hline
\end{tabular}

Fonte: ALICEWEB/MDIC (2014)

Tabela 3.3: Destino das exportações de farelo de soja em 2014

\begin{tabular}{c|c|c|c}
\hline \hline Período & País & US\$FOB & Volume (Ton) \\
\hline JANEIRO/FEVEREIRO & PAÍSESBAIXOS (HOLANDA) & 252.121 .287 & 447.849 \\
\hline & FRANÇA & 102.873 .529 & 209.330 \\
\hline & ALEMANHA & 100.839 .306 & 188.481 \\
\hline & POLÔNIA & 33.539 .402 & 67.608 \\
\hline & ESLOVÊNIA & 33.857 .103 & 66.426 \\
\hline & TAILÂNDIA & 34.741 .089 & 61.751 \\
\hline & INDONÉSIA & 30.822 .653 & 54.900 \\
\hline & IRÁ & 19.870 .207 & 39.317 \\
\hline & ARGÉLIA & 8.831 .897 & 16.491 \\
\hline & VIETNẤ & 5.700 .036 & 10.909 \\
\hline & ITÁLIA & 4.050 .000 & 8.000 \\
\hline & ESPANHA & 1.941 .448 & 3.943 \\
\hline & GEÓRGIA & .859 .623 & 3.286 \\
\hline & REINO UNIDO & 777.488 & 1.649 \\
\hline & CAMARÕES & 481.502 & 1.090 \\
\hline & CONGO & 650.000 & 1.000 \\
\hline & SENEGAL & 88.104 & 134 \\
\hline \hline
\end{tabular}

Fonte: ALICEWEB/MDIC (2014) 
Tabela 3.4: Evolução das exportações de óleo de soja por porto em 2014

\begin{tabular}{c|c|c|c}
\hline \hline Período & Porto & US\$ FOB & Volume (Ton) \\
\hline JANEIRO/FEVEREIRO & PORTO DE PARANAGUÁ -PR & 47.933 .510 & 53.695 \\
\hline & PORTO DE RIO GRANDE - RS & 29.548 .195 & 32.145 \\
\hline & SANTOS - SP & 13.015 .888 & 13.960 \\
\hline & MANAUS - AM & 9.771 .281 & 2.002 \\
\hline & ITAJAI - SC & 2.764 .928 & 2.141 \\
\hline & CHUI - RS & 1.277 .877 & 1.331 \\
\hline & GUAJAA - MIRIM -RO & 884.309 & 771 \\
\hline & CORUMBA - MS & 729.040 & 729 \\
\hline & FOZ DO IGUACU - PR & 344.207 & 337 \\
\hline & PONTA PORA - MS & 360.982 & 337 \\
\hline & JAGUARÃO - RS & 356.547 & 158 \\
\hline & CORUMBA - MS & 157.720 & 114 \\
\hline & BRASILEIA - AC & 132.119 & 111 \\
\hline & ASSIS BRASIL -AC & 131.040 & 99 \\
\hline & SÃO FRANCISCO -SC & 125.400 & 16 \\
\hline & RIO DEJANEIRO -RJ & 20.740 & 0,01 \\
\hline \hline
\end{tabular}

Fonte: ALICEWEB/MDIC (2014)

Tabela 3.5: Destino das exportações de óleo de soja em 2014

\begin{tabular}{|c|c|c|c|}
\hline Período & País & $\overline{\text { US\$FOB }}$ & "Volume(Ton) \\
\hline \multirow{26}{*}{ JANEIRO/FEVEREIRO } & ÍNDIA & 48.455 .511 & 53.973 \\
\hline & BANGLADESH & 16.686 .607 & 19.672 \\
\hline & ARGÉLIA & 9.771 .281 & 12.002 \\
\hline & EGITO & 7.046 .122 & 7.639 \\
\hline & CUBA & 7.989 .959 & 7.500 \\
\hline & CHINA & 5.546 .595 & 5.999 \\
\hline & MARROCOS & 3.125 .986 & 3.458 \\
\hline & BOLÍVIA & 1.905 .009 & 1.774 \\
\hline & URUGUAI & 1.634 .424 & 1.660 \\
\hline & PERU & 1.348 .878 & 1.105 \\
\hline & AUSTRÁLIA & 682.500 & 700 \\
\hline & PARAGUAI & 705.189 & 674 \\
\hline & COLÔMBIA & 665.059 & 547 \\
\hline & VENEZUELA & 792.809 & 526 \\
\hline & NOVA ZELÂNDIA & 487.500 & 500 \\
\hline & GUIANA & 217.220 & 176 \\
\hline & SURINAME & 191.913 & 155 \\
\hline & ANGOLA & 104.254 & 67 \\
\hline & ANTÍGUA E BARBUDA & 76.597 & 57 \\
\hline & MOÇAMBIQUE & 19.228 & 22 \\
\hline & COREIA DO SUL & 13.181 & 21 \\
\hline & HAITI & 24.219 & 19 \\
\hline & PAÍSES BAIXOS (HOLANDA) & 34.414 & 15 \\
\hline & SÃO VICENTE E GRANADINAS & 14.639 & 10 \\
\hline & GUINÉ E QUATORIAL & 16.248 & 7 \\
\hline & JAPÃO & 313 & 0,01 \\
\hline Total & & 107.555.655 & 118.729 \\
\hline
\end{tabular}

Fonte: ALICEWEB/MDIC (2014) 
Tabela 3.6: Evolução das exportações da soja em grãos por porto em 2014

\begin{tabular}{c|c|c|c}
\hline \hline Período & Porto & US\$ FOB & Volume (Ton) \\
\hline JANEIRO/FEVEREIRO & PORTO DE PARANAGUA - PR & 488.036 .372 & 1.004 .639 \\
\hline & SANTOS- SP & 425.054 .229 & 844.552 \\
\hline & SÃO FRANCISCO DO SUL - SC & 156.457 .293 & 315.822 \\
\hline & VITORIA - PORTO ES & 91.644 .541 & 182.649 \\
\hline & SANTARÉM -PA & 81.402 .487 & 159.816 \\
\hline & PORTO DE RIO GRANDE - RS & 77.614 .095 & 154.474 \\
\hline & MANAUS - PORTO-AM & 66.115 .744 & 122.616 \\
\hline & SALVADOR - PORTO - BA & 16.798 .787 & 34.795 \\
\hline & ITAJAI - SC & 273.614 & 517 \\
\hline & URUGUAIANA - RODOVIA-RS & 125.749 & 188 \\
\hline & NÃO DECLARADO - ND & 96.513 & 165 \\
\hline & FOZ DO IGUAÇU - RODOVIA - PR & 22.140 & 23 \\
\hline \hline & CAMPINAS - AEROPORTO - SP & 1 & 0,01 \\
\hline & & $\mathbf{1 . 4 0 3 . 6 4 1 . 5 6 5}$ & $\mathbf{2 . 8 2 0 . 2 5 6}$ \\
\hline
\end{tabular}

Fonte: ALICEWEB/MDIC (2014)

Tabela 3.7: Destino das exportações da soja em grãos em 2014

\begin{tabular}{c|c|c|c}
\hline \hline Período & País & US\$FOB & Volume (Ton) \\
\hline JANEIRO/FEVEREIRO & CHINA & 1.171 .163 .089 & 2.362 .041 \\
\hline & REINO UNIDO & 55.143 .877 & 108.963 \\
\hline & TAILÂNDIA & 47.231 .551 & 94.470 \\
\hline & ESPANHA & 33.647 .768 & 67.881 \\
\hline & COREIA DO SUL & 25.298 .188 & 52.400 \\
\hline & PAÍSES BAIXOS (HOLANDA) & 18.745 .629 & 39.067 \\
\hline & FINLÂNDIA & 16.798 .787 & 34.795 \\
\hline & RÚSSIA & 15.198 .759 & 22.560 \\
\hline & TAIWAN (FORMOSA) & 8.775 .140 & 16.572 \\
\hline & MALÂSIA & 3.873 .555 & 7.732 \\
\hline & VIETNÂ & 3.173 .002 & 5.965 \\
\hline & ALEMANHA & 2.379 .039 & 4.158 \\
\hline & ITÁLIA & 1.503 .911 & 2.649 \\
\hline & JAPÃO & 394.539 & 544 \\
\hline & ARGENTINA & 125.749 & 188 \\
\hline & GUIANA & 96.513 & 165 \\
\hline & CINGAPURA & 70.328 & 83 \\
\hline \hline & PARAGUAI & 22.140 & 23 \\
\hline & ESTADOS UNIDOS & 1 & 0,01 \\
\hline
\end{tabular}

Fonte: ALICEWEB/MDIC (2014)

Demonstrada a importância de cada elo para a cadeia logística da soja brasileira, o próximo tópico versa sobre a movimentação da soja no Brasil, os modais de transporte utilizados e as principais rotas pelas quais a soja passa até chegar ao porto. 


\subsubsection{Movimentação, Modais Utilizados, e Principais Rotas da Soja no Brasil}

A movimentação da soja inicia-se com o processo de transporte, a partir do agricultor para os silos de armazenamento, e daí para as unidades expedidoras e/ou processadoras. Pode também ocorrer diretamente do produtor para as unidades processadoras ou portos para exportação; já no caso do grão processado, o transporte tem origem nas unidades processadoras com destino a consumidores fabris, no mercado doméstico e para exportação (como o caso do farelo de soja).

As exportações da soja em grão costumam ser realizadas pelas empresas de trading. A negociação da safra da soja é frequentemente realizada com antecipação. Esta é uma forma de evitar uma pressão excessiva nos preços nos meses de safra e, ao mesmo tempo, financiar a lavoura, pois parte da safra é entregue às empresas de trading em troca de insumos (COELI, 2004).

Segundo Coeli (2004), o escoamento da produção de grãos de soja no Brasil ocorre em duas etapas:

1. Transporte das lavouras para o armazém da fazenda: costuma ser de responsabilidade do produtor, sendo feito através de carretas. Seu custo é elevado devido à ausência de pavimentação nas estradas rurais. Trata-se de um transporte local e extremamente pulverizado, não sendo, portanto, o foco de análise deste estudo.

2. Transporte dos armazéns dos produtores diretamente para exportação ou para a indústria de processamento: a partir dos armazéns dos produtores, a soja em grão segue por ferrovias, rodovias ou hidrovias, para ser direcionada para exportação (portos). A soja em grão costuma ser transportada à granel, embora haja ocasiões em que é ensacada antes da movimentação. A soja em grão também pode ser transportada para as indústrias de processamento, para ser transformada em farelo ou óleo.

Para Aldigueri e Oliveira (2009), existem diferentes possibilidades de transporte de soja entre as lavouras e o Porto de Paranaguá, por exemplo: (i) escoamento de soja direto entre áreas agrícolas (fazendas) e porto, sem armazenagem; (ii) 15\% da produção de grãos de soja e farelo total podem ser armazenados nas propriedades agrícolas, 
esperando melhores preços de frete (entressafra) e os $85 \%$ restantes são transportados diretamente para Paranaguá; (iii) aumento da capacidade de armazenagem nas fazendas - 50\% da produção de grãos de soja e farelo total podem ser armazenados nas propriedades agrícolas, esperando melhores preços de frete (entressafra), e os 50\% restantes são transportados diretamente para Paranaguá.

A movimentação da soja dos principais pólos produtores com destino ao mercado externo pode se dar por diferentes modais de transporte. A seguir são descritas as principais rotas utilizadas para a exportação da soja com base no estudo desenvolvido por Barone e Ojima (2008):

Região Sul: nesta região, estão localizadas as áreas tradicionais de produção de grãos. As rodovias já estão implantadas, interligando os diversos centros produtores até os portos de exportação. No estado do Paraná, há a BR-376 e a BR-277, as quais ligam os centros produtores ao porto de Paranaguá (PR). O Rio Grande do Sul conta com a BR386 e a BR-153 até o porto de Rio Grande (RS). Existe ainda a opção rodo-hidroviário com a hidrovia Jacuí-Lagoa dos Patos, a qual está localizada no Estado do Rio Grande do Sul e interliga os centros produtores até o Terminal Hidroviário de porto Estrela (RS). Na região do Rio Grande, existe também a opção pela América Latina Logística (ALL), ferrovia que atua na região Sul do Brasil e é uma das principais rotas praticadas no escoamento da safra de soja do norte do estado do Paraná ao porto de Paranaguá. Essa opção também capta soja proveniente da região Centro-Sul, utilizando o transporte rodoferroviário.

Região Sudeste: a região Sudeste conta com diversas rodovias, dentre elas, a BR-050 que liga o Triângulo Mineiro a São Paulo. Pode-se também seguir pela Hidrovia TietêParaná, que é utilizada para o transporte de grãos da região Centro-Oeste, principalmente do estado de Goiás, com destino ao terminal hidroviário de Pederneiras (SP), e daí segue pela Ferrovia Ferroban até o porto de Santos (SP). Pode-se ainda desembarcar no terminal hidroviário de Panorama (SP), chegando até o porto de Santos de caminhão. Outras opções são a Ferrovia Centro-Atlântica e a Estrada de Ferro Vitória-Minas, de propriedade da Companhia Vale do Rio Doce, as quais atuam nos Estados de Minas Gerais, São Paulo e Goiás. O principal porto de destino é o porto de Tubarão (ES). 
Região Centro-Oeste: as principais rodovias da região Centro-Oeste são BR-163 e BR 364. A primeira liga as áreas produtoras do estado do Mato Grosso ao porto de Paranaguá (PR), enquanto que a BR-364 interliga o estado do Mato Grosso aos estados do Mato Grosso do Sul e ao de Rondônia, e no sentido contrário, ao porto de Santos (SP). Como partes da reorientação do escoamento da produção regional, foram concluídos recentemente o prolongamento e a pavimentação das rodovias BR-070 e BR-174 no sentido de Cuiabá e Porto Velho. Existe a opção intermodal rodoferroviária com a Brasil Ferrovias, empresa composta por três ferrovias: Ferronorte, que interliga o estado do Mato Grosso ao porto de Santos; Novoeste, que interliga o estado do Mato Grosso do Sul ao porto de Santos; Ferroban, que atua no estado de São Paulo. Essa união de ferrovias também exerce influência nos estados vizinhos como Goiás e Minas Gerais, funcionando com uma opção logística rodoferroviária adicional.

Região Nordeste: a produção do estado da Bahia pode ser escoada pelas rodovias de ligação BR-430 e BR-415 até o porto de Ilhéus (BA), e a BR-135 até o porto de Itaqui (MA). Nos estados do Piauí e Maranhão, utiliza-se a rodovia BR-230 até o Estreito (MA), onde a opção é seguir pela a ferrovia Norte-Sul, a qual se liga à estrada de Ferro Carajás, de onde segue para o porto de Itaqui. A Ferrovia Norte-Sul e a Estrada de Ferro Carajás atuam ainda nos estados de Tocantins, Pará e Piauí uma opção rodoferroviária.

Norte: uma das principais regiões produtoras é o estado de Rondônia e sua principal rodovia é a BR-364, a qual a interliga até o município de Porto Velho (RO). Ainda em fase experimental, a produção do estado de Roraima é escoada até Manaus pela BR174. Outra opção rodo-hidroviário é a Hidrovia do Madeira, que é utilizada principalmente para o transporte de grãos provenientes desta região, incluindo o norte do estado do Mato Grosso. Os grãos também podem chegar ao terminal hidroviário de Porto Velho, seguindo pela hidrovia até o terminal de Itacoatiara (AM), e daí navegarem pelo rio Amazonas rumo ao oceano.

O conhecimento das alternativas de transporte da soja e de seus principais corredores torna mais fácil a identificação dos riscos de contaminação, bem como o levantamento dos tempos e custos logísticos adicionais para fazer a segregação da soja ao longo da cadeia. 
Trabalhada a revisão bibliográfica sistemática nos capítulo 2 e 3, os próximos capítulos trazem os resultados da pesquisa de campo propostos para essa tese. 


\section{PONTOS CRÍTICOS PARA O PROCESSO DE SEGREGAÇÃO E NÃO CONTAMINAÇÃO DA SOJA CONVENCIONAL NA CADEIA LOGÍSTICA BRASILEIRA}

\subsection{ASPECTOS GERAIS}

Neste capítulo, são mostradas as informações coletadas na pesquisa de campo junto aos agentes da cadeia logística da soja referentes à primeira etapa da pesquisa.

O capítulo foi estruturado da seguinte forma: 1) Aspectos Gerais; 2) são apresentadas as estratégias adotadas por dois produtores que fazem a segregação da soja em suas fazendas, bem como todos os riscos de contaminação, e os procedimentos que são adotados para se conseguir a separação e não contaminação da soja; 3) são apresentados os resultados das entrevistas feitas com três transportadores de soja transgênica e convencional, emblematicamente como é feito o transporte dos produtores e dos armazenadores/processadores; 4) são apresentadas as estratégias utilizadas por um armazenador/processador para fazer a segregação do produto em sua unidade, bem como todos os procedimentos que são adotados por eles para a recepção da soja em sua unidade e envio do farelo para o porto, além de mostrar aspectos relacionados ao recebimento dos prêmios; 5) são apresentados os resultados obtidos nas entrevistas com os operadores portuários, mostrando onde deve haver os maiores cuidados para a não contaminação da soja. As dificuldades de se fazer a limpeza nos armazéns, máquinas, equipamentos e porões dos navios também serão mostradas; 6) por fim, são apresentados os resultados obtidos em entrevistas com 10 produtores rurais e 3 armazenadores/processadores que faziam a segregação da soja e não mais a fazem.

Os processos são descritos e apresentados em forma de fluxogramas para melhor entendimento e compreensão de como se dá a lógica de todo o processo, desde a compra da semente até a entrega da soja no navio. 


\subsection{PRODUTORES QUE FAZEM A SEGREGAÇÃO DA SOJA}

Por meio das entrevistas com dois produtores rurais que fazem a segregação da soja em suas fazendas, foi possível constatar os processos e as estratégias utilizadas para fazer a separação da soja em suas propriedades, bem como as estratégias que estão utilizando para fazer a segregação da soja ao longo da cadeia logística.

Com essa pesquisa foi possível identificar e verificar as etapas e processos pelas quais a soja passa, mostrando os fluxos logísticos desde a compra da semente, até o produto ser expedido da fazenda do produtor, identificando os processos em que deve haver maiores cuidados para a não contaminação ou até a necessidade da total segregação.

\subsubsection{Etapa 1: Processo de Compra de Insumos dos Produtores que Fazem a Segregação}

A Figura 4.1 mostra o processo logístico de compra de insumos para os dois tipos de soja. 
próprias sementeiras reconhecem esse problema. Por isso, eles já estão trabalhando para melhorar seus campos de plantio, deixando-os mais puros.

Estudos feitos por Ferment et al. (2009) mostram que pelo menos 9\% das amostras de sementes de soja convencionais testadas apresentam contaminação genética, o que torna ainda mais difícil a segregação e corrobora com o que foi dito pelos produtores entrevistados.

Os produtores informaram que é muito difícil encontrar sementes de soja convencional com a pureza necessária para fazer o plantio. Para conseguir essa semente, é necessário fazer um planejamento de pelo menos seis meses de antecipação ao plantio para não correr o risco de ficar sem semente com alto teor de pureza perto da entressafra. Caso isso não aconteça, sujeitar-se-ão a ter que comprar uma semente que não seja muito confiável, o que aumentaria drasticamente os riscos de contaminação.

No momento da aquisição da semente transgênica, há duas possibilidades de pagamento dos royalties para o produtor: na compra da semente ou na venda do produto. Se for feita na compra da semente, é gerado imediatamente um crédito de isenção para o produtor, que deverá apresentá-lo na venda do produto, a fim de não pagar os royalties para a Monsanto. A segunda opção é o pagamento dos royalties na venda do produto, o que significa $2 \%$ sobre toda a carga.

Nesse fluxograma, pode-se perceber a diferença entre ambos, e os cuidados que se devem ter ao longo de todo o processo, principalmente os relacionados à limpeza dos caminhões que irão transportar o adubo do fornecedor até a fazenda. Esses aspectos são importantes, porque pode ser que haja contaminação na hora de descarregar a soja na fazenda, uma vez que se a limpeza não for bem realizada, e sobrar vestígios de grãos transgênicos na carroceria, possivelmente poderá sobrar algum grão que será jogado na lavoura da soja convencional; o qual, possivelmente, poderá germinar, ocasionando a contaminação.

Caso o adubo não seja jogado diretamente na terra em seu transbordo na fazenda, será necessário fazer o armazenamento do adubo da soja convencional em local diferente da 
transgênica, pois na carga de adubo da soja transgênica não é exigida a limpeza do caminhão, podendo ter havido a contaminação.

Segundo informações dos produtores, além de ter o cuidado na limpeza dos caminhões, seria necessário ter um controle maior no armazenamento do adubo, colocando-o separadamente para minimizar ainda mais os problemas da contaminação. Fazendo isso, seria necessário fazer a limpeza apenas nos caminhões de adubo destinados à soja convencional, os quais seriam depositados em espaços separados do adubo da soja transgênica. Se isso for feito, não é necessário fazer a limpeza dos caminhões.

Há dois processos adicionais para a soja convencional: primeiro, a limpeza do caminhão que carregará o adubo e, segundo, a limpeza do armazém que receberá os defensivos da soja convencional e do adubo, caso sejam colocados separadamente. Muitas vezes, não há necessidade de estocar o adubo, porque quando ele chega à fazenda já é diretamente jogado na terra. Porém, quando há necessidade de estocar o adubo, é importante que se faça um planejamento e controle muito rigoroso do espaço que será destinado à soja convencional, limpando toda área reservada ao recebimento do adubo destinado a esta soja.

Um fator contratual importante a ser ressaltado neste processo é a contratação do transportador do adubo. Um dos produtores informou que há a exigência da limpeza da carroceria, para que o adubo seja transportado, uma vez que o caminhão pode ter feito transporte de soja transgênica e ficado algum vestígio de semente na carroceria. Este adubo, possivelmente, poderá ser jogado na terra, causando a germinação de plantas transgênicas em solos que são destinados à soja convencional, ocasionando, dessa forma, a possível contaminação.

Atualmente, os produtores exigem do transportador que faz a entrega do adubo na fazenda uma orientação contratual, a fim de que seja feita uma limpeza adequada nos caminhões. Os produtores, no entanto, reconhecem ser difícil fazer a fiscalização para se assegurar que os transportadores realmente cumpram com a exigência da varredura. A situação ideal seria aquela em que o produtor mandasse um de seus funcionários altamente qualificados para acompanhar a limpeza. Esta não é paga ao transportador. Talvez a solução para a melhoria desse processo seria que o valor adicional da limpeza 
fosse solicitado em contrato, para que houvesse maior cuidado nesse processo tão importante para a não contaminação.

Há também a necessidade de armazenamento da semente da soja transgênica de forma separada da soja convencional, de modo que não haja risco de contaminação por algum saco que possa estar danificado, ou por descuido de algum funcionário que pode pegar o saco por engano.

\subsubsection{Etapa 2: Processo de Preparação do Solo dos Produtores que Fazem a Segregação}

A próxima etapa é o processo de preparação do solo para o plantio, representado pela Figura 4.2, a qual mostra desde as atividades de preparação do solo até a espera do plantio propriamente dito. 


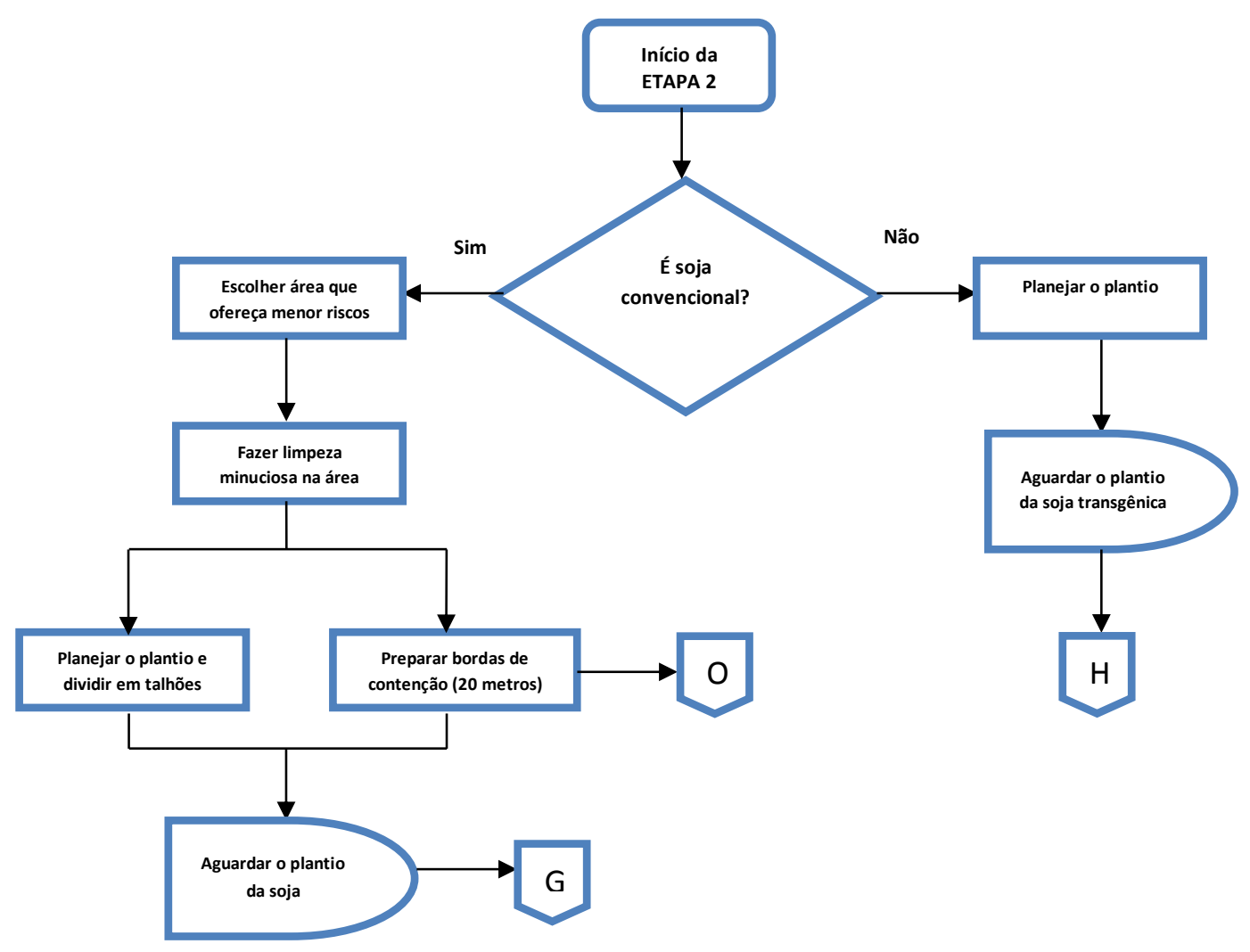

Figura 4.2: Etapa 2 - Processo de preparação do solo para plantio Fonte: Elaborado pelo autor (2014)

Neste processo, há maiores cuidados com a soja convencional do que com a transgênica. Todos estes processos excedentes despendem um tempo adicional e maiores custos para os produtores que fazem a segregação.

O produtor precisa escolher uma área que tenha menor risco de contaminação para a soja convencional. Uma área que já foi plantada com soja transgênica deverá passar por um processo criterioso de limpeza, pois podem ter sobrado grãos remanescentes de soja transgênica que poderão germinar no campo escolhido para a soja convencional. A triagem da área é feita com a ajuda de dados históricos de plantio, sendo escolhidas aquelas áreas onde nunca tenham sido plantada soja transgênica, ou que pelo menos tenha sido utilizado o menor número de vezes possível.

Depois da escolha da área, o próximo passo é fazer as bordas de contenção de 20 metros quadrados para diminuir a possibilidade de contaminação por polinização cruzada. Isso já é corriqueiramente feito no plantio do milho transgênico, inclusive regulamentado por lei. Esses 20 metros, depois de colhidos, são descartados e armazenados juntos à soja transgênica para não correr o risco da contaminação. 
Eles informaram também que, às vezes, a bordas de contenção podem ser feitas com o plantio do milho, reduzindo a perda do prêmio que eles poderiam receber com a soja livre de transgênicos nos 20 metros utilizados como borda de contenção.

Segundo Ferment et al. (2009), no caso da soja, o isolamento espacial de algumas dezenas de metros, acompanhado por uma borda de contenção de soja convencional em volta da parcela transgênica, deveria diminuir o risco de contaminação por polinização a um valor próximo de zero. Contudo, há a possibilidade de mistura de sementes durante a colheita, transporte, armazenamento e processamento. Nesse caso, o risco zero não existe, e não se pode excluir totalmente um fluxo de pólen por insetos polinizadores e utilização de máquinas agrícolas contaminadas, dentre outros fatores. Segundo a CTNBIo (2007 apud FERMENT et al., 2009), o índice estimado de polinização cruzada é de $1 \%$.

\subsubsection{Etapa 3: Processo de Plantio e Aplicação dos Defensivos dos Produtores que Fazem a Segregação}

A próxima etapa refere-se ao processo de plantio. A Figura 4.3 mostra os processos dos dois tipos de soja, desde a preparação da plantadeira até a espera da colheita. O que pode ser constatado é que, no plantio da soja convencional, há mais processos e riscos de contaminação, sobretudo na limpeza das plantadeiras, além dos custos adicionais com o maior número de aplicação de defensivos. 


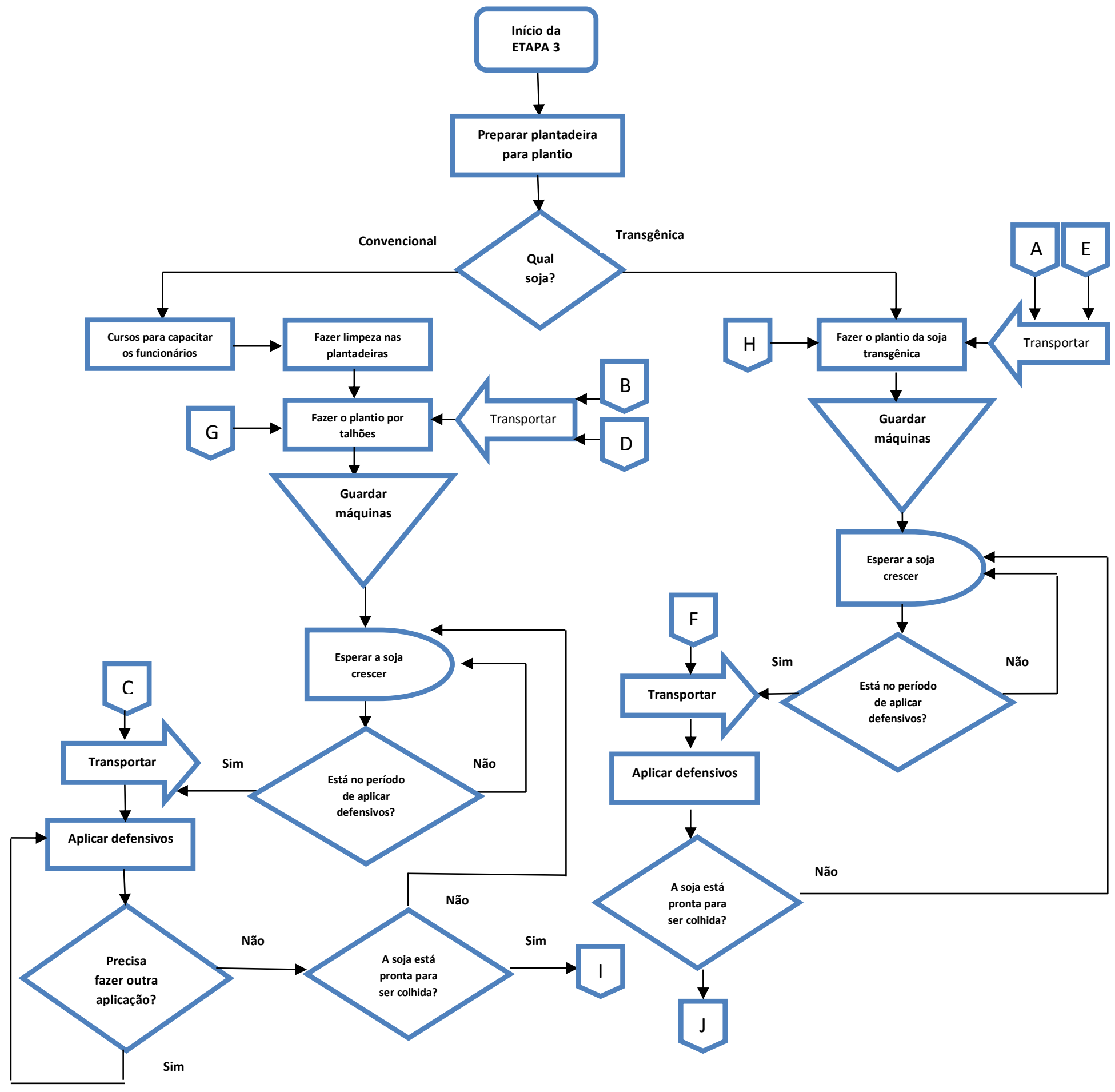

Figura 4.3: Etapa 3 - Processo de plantio e aplicação de defensivos

Fonte: Elaborado pelo autor (2014)

Os produtores informaram que para fazer a limpeza das plantadeiras é necessário parar todas as plantadeiras que estavam plantando soja transgênica, tirar toda a soja remanescente, passar a "vassourinha", assoprar, abrir todas as "caixas" da máquina para que se consiga garantir que não sobre vestígios de soja transgênica. 
O custo aumenta pela necessidade de mais de uma aplicação de defensivos na soja convencional.

Outro investimento que deve ser feito é na capacitação e controle dos funcionários que irão fazer o plantio e a colheita, mostrando todos os cuidados e procedimentos que devem ser feitos na limpeza das máquinas no momento do plantio e da colheita da soja.

Nota-se através da Figura 4.3 que os processos destinados ao plantio da soja transgênica têm uma exigência menor, e possivelmente menores custos.

\subsubsection{Etapa 4: Processo de Colheita dos Produtores que Fazem a Segregação}

Depois que o processo de plantio é realizado, passa-se à colheita, cujo processo pode ser visualizado na Figura 4.4. Mais uma vez, pode ser observado que há mais atividades no fluxo do processo da soja convencional do que no da transgênica, tais como: limpeza das colheitadeiras, limpeza dos caminhões e espera para o carregamento da soja transgênica (caso as duas estejam sendo carregadas ao mesmo tempo). Estas últimas precisam de um cuidado especial para que não haja contaminação da soja transgênica pela convencional. 


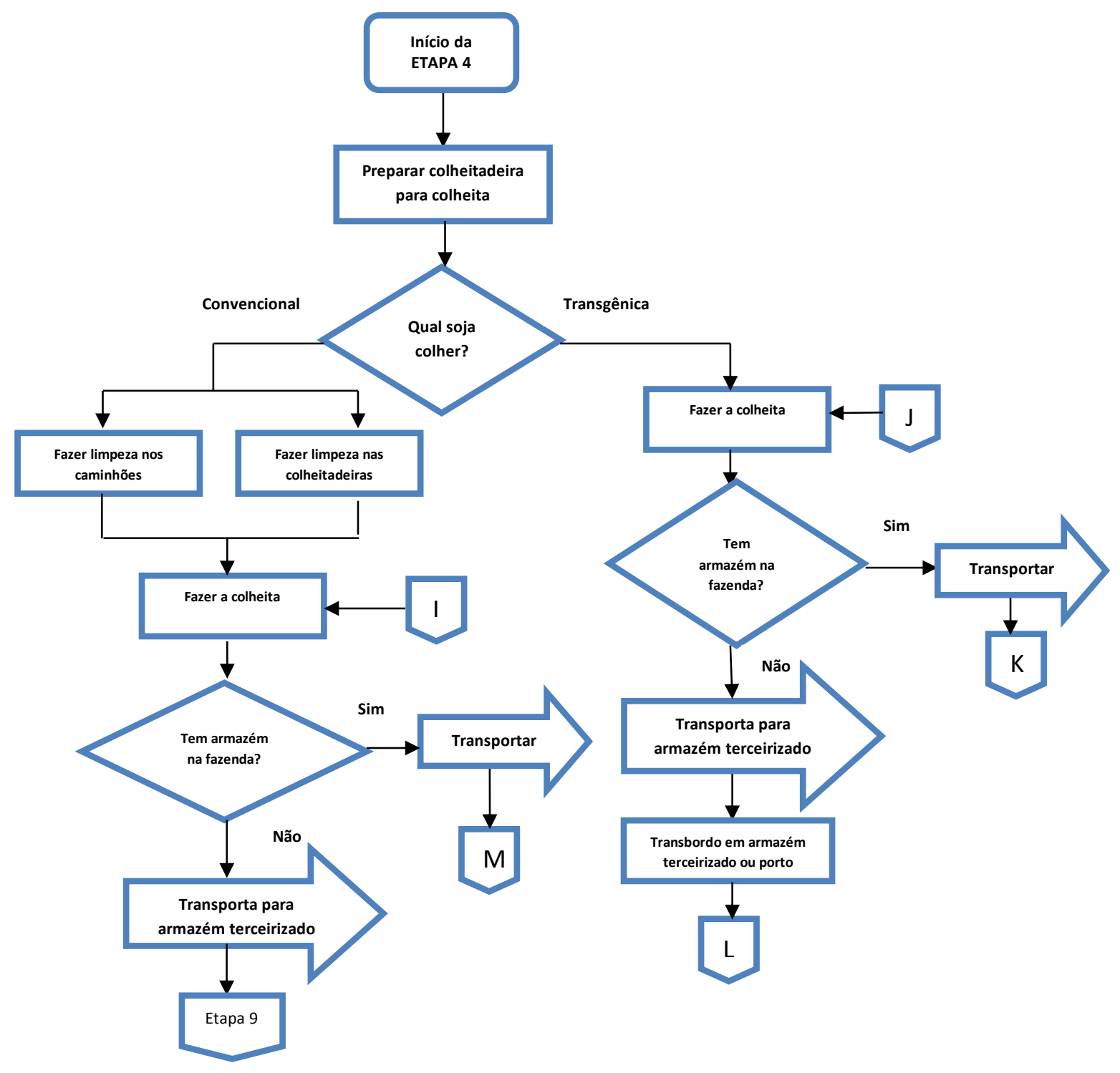

Figura 4.4: Etapa 4 - Processo de colheita

Fonte: Elaborado pelo autor (2014)

Os produtores entrevistados informaram ter que fazer uma limpeza muito bem elaborada nas máquinas, para não sobrar nenhum vestígio de grãos transgênicos. Informaram que na oportunidade da colheita chamam todos os funcionários e oferecem um curso de quase um dia para explicar todos os procedimentos a serem adotados, e os possíveis problemas que a contaminação pode acarretar na receita da empresa. Todo o processo é explicado para os funcionários, desde a compra da semente até o momento que a soja sai da fazenda.

Caso o produtor tenha armazém na fazenda, ele armazena a soja e aguarda sua expedição. Caso o produtor não o tenha, ele é obrigado a enviar a soja para um armazém terceirizado ou diretamente para o porto. Se enviar a soja para o armazém terceirizado, 
deverá estar ciente de que este pode não fazer a segregação em sua unidade, devendo optar pela opção de envio direto para o porto.

\subsubsection{Etapa 5a: Processo de Armazenagem dos Produtores que Fazem a Segregação Utilizando o Mesmo Armazém / Etapa 5b: Processo de Armazenagem dos Produtores que Fazem a Segregação Utilizando Dois Armazéns}

Para fazer a armazenagem da soja, há duas possibilidades: utilizar o mesmo armazém ou utilizar unidades totalmente separadas. Primeiramente, será mostrada a estratégia de segregação utilizada por um dos produtores para armazenar a soja em um mesmo armazém. O outro produtor entrevistado faz a segregação em unidades totalmente segregadas. Mostraremos esse processo posteriormente.

A armazenagem dos dois tipos de soja na mesma instalação é mais complexa, o que gera mais operações para manter a qualidade e pureza do produto. Veja a Figura 4.5. 


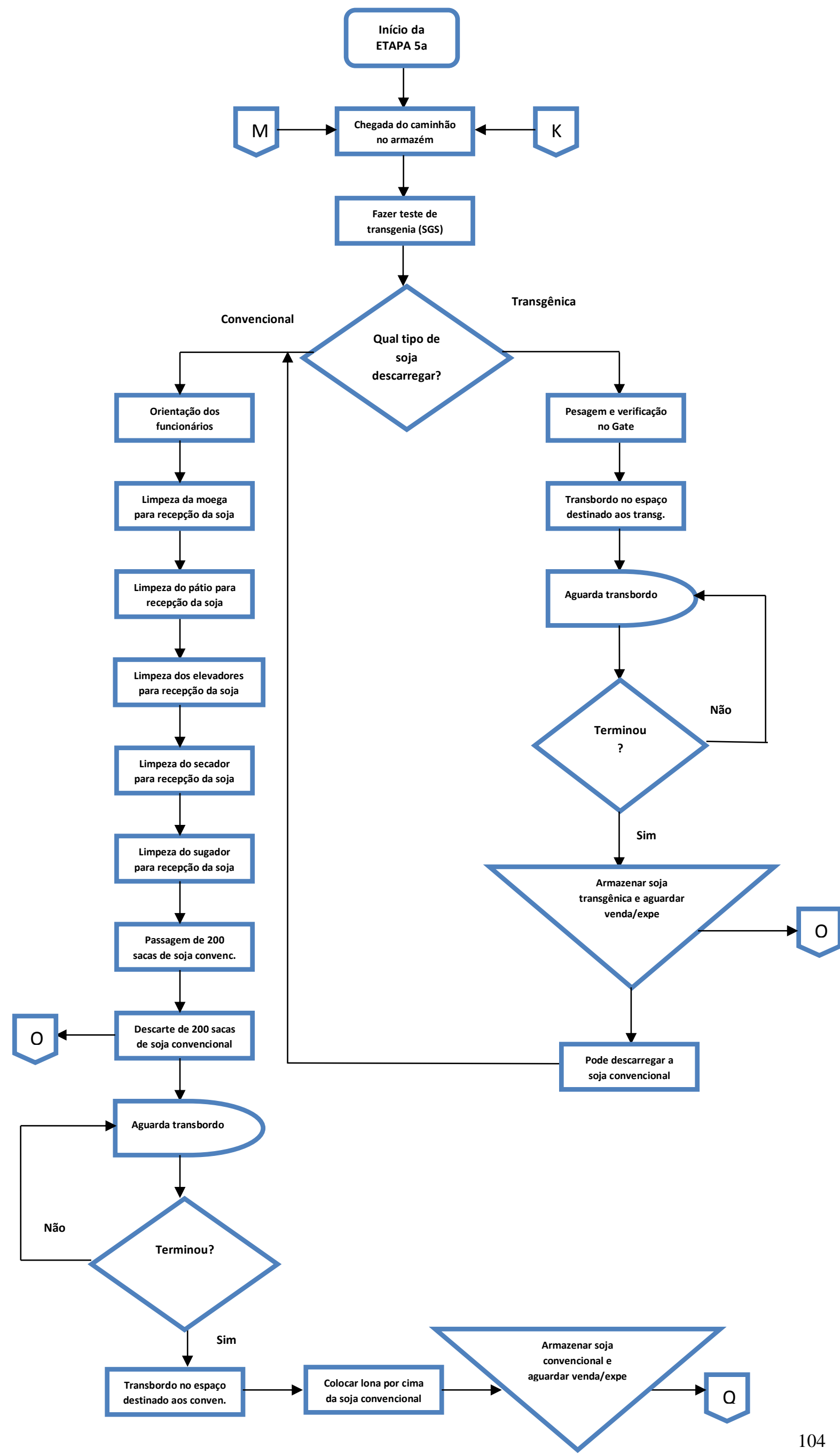


Figura 4.5: Etapa 5a - Processo de armazenagem utilizando o mesmo armazém do produtor

Fonte: Elaborado pelo autor (2014)

A Figura 4.5 mostra os processos nos quais se devem ter maiores cuidados para a não contaminação, tais como: orientação e controle dos funcionários para fazer a armazenagem, limpeza da moega, do pátio, dos elevadores, dos secadores e do sugador. Depois que toda a limpeza é realizada, é feita a passagem de 200 sacas $^{18}$ de soja convencional em todo canal de expedição, a fim de se conseguir a total limpeza, pois, se houver ainda algum vestígio em qualquer equipamento, este será eliminado na passagem das 200 sacas. Posteriormente essa soja é descartada como soja transgênica. Por fim, é necessário colocar uma lona por cima da soja convencional para sua proteção, pois as esteiras carregadas com soja transgênica passam justamente por cima do espaço destinado à soja livre de transgênicos, a qual também é descartada para o armazém da soja transgênica. Feito isso, pode-se enfim dar início ao processo de armazenagem da soja convencional.

Além disso, antes de a soja ser colocada no armazém, é feito um teste SGS (os detalhes sobre estes testes serão mostrados mais adiante nesta tese) para saber se todo o processo anterior à armazenagem foi realizado com êxito. Caso seja acusada transgenia, a soja daquele caminhão que foi feito o teste é descartada e colocada no espaço destinado à soja transgênica. Para o total controle e garantia da pureza do produto, é necessário que sejam realizados os testes em todos os caminhões antes de sua entrada no armazém.

Os produtores informaram que é muito difícil fazer a segregação da soja quando se utiliza o mesmo armazém. Os produtos ficam separados apenas por uma parede de concreto.

Para facilitar o gerenciamento do armazém, os produtores relataram que é importante fazer, primeiramente, toda a colheita de um tipo de soja e posteriormente da outra. Porém, nem sempre se consegue êxito nessa estratégia, porque há diferentes variedades de soja (precoces e tardias), dificultando a gestão do armazém. Quando isso acontece,

\footnotetext{
${ }^{18} \mathrm{O}$ próprio produtor entrevistado informou que essa é a quantidade necessária para que obtenha êxito na limpeza e garantia da pureza do produto.
} 
toda vez que há necessidade de armazenagem da soja convencional, é necessário fazer novamente todo o processo de limpeza ao longo do armazém.

Nos elevadores e dentro dos silos, é também necessário fazer uma limpeza/varredura muito minuciosa para que não fique nenhum grão transgênico. Os produtores informaram que há um risco muito grande de passar soja convencional e transgênica ao mesmo tempo, ainda que elas estejam indo para canais diferentes em tubulações diferentes, porque pode haver algum buraco na tubulação, o qual poderá ocasionar a contaminação. Segundo os produtores, o processo é tão arriscado que mesmo quando os registros das tubulações são fechados, há a possibilidade de contaminação.

Outra forma de fazer a segregação da soja e evitar maiores problemas de contaminação, é ter um armazém exclusivo para a soja convencional. Um dos produtores entrevistados disse ter um armazém específico só para receber a soja convencional, o que facilita todo o processo. Sendo assim, faz a segregação da soja utilizando unidades de recebimento totalmente separadas, conforme mostrado na Figura 4.6. 


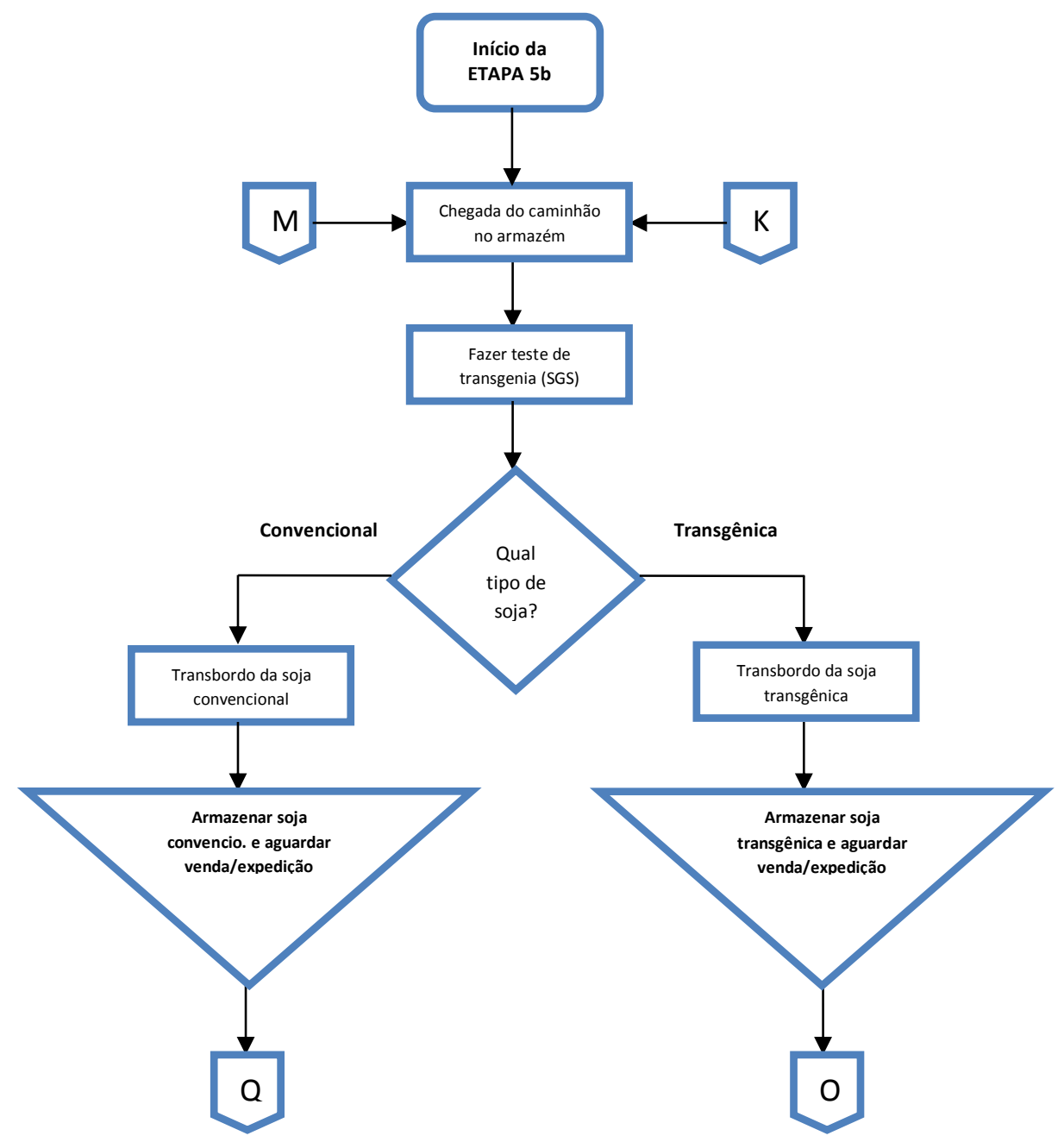

Figura 4.6: Etapa 5b - Processo de armazenagem utilizando dois armazéns do produtor Fonte: Elaborado pelo autor (2014)

Pode-se observar que as operações são drasticamente diminuídas, se comparadas com o processo anterior. Porém, o produtor mencionou que o investimento para a construção de um novo silo específico para o recebimento da soja livre de transgênicos é muito elevado, e só é compensatório se for recebido o prêmio, argumentando que há anos que, mesmo fazendo a segregação da soja, não lhe é garantido este recebimento, ficando nas mãos dos armazenadores/processadores que pagarão ou não o prêmio, a depender do fechamento de contratos no mercado internacional de entrega da soja livre de transgênicos.

Isso traz uma reflexão sobre a importância dos armazenadores/processadores na cadeia logística da soja, os quais podem ditar comportamentos a montante e a jusante, pois são eles que coordenam todos os contratos de compra e venda da soja livre de transgênicos, 
além de fazerem o pagamento do prêmio para os produtores a partir do fechamento de contratos no mercado internacional.

Diante dessa informação, pode-se afirmar que os armazenadores são vistos como coordenadores de contratos, em que a confecção destes com cada elo da cadeia merecerá tratamento diferente.

Acerca dos contratos, torna-se importante ressaltar que o fechamento destes entre armazenador/processador (que paga o prêmio) e produtor rural (que recebe o prêmio) dependerá da existência da quantidade de produtores ofertantes capazes de entregar a soja livre de transgênicos (quanto mais ofertantes, menor será o preço do prêmio pago ao produtor; lei da oferta e demanda), e de sua reputação, baseada no histórico de fornecimento da soja não contaminada (pois há histórico de produtores que fecharam contratos de entrega de soja livre de transgênicos, porém não conseguiram honrar seus compromissos, entregando soja contaminada). Existem ainda outros fatores que podem influenciar a contratação ou não do produtor para a entrega da soja livre de transgênicos na empresa armazenadora/processadora. Talvez seja esse o motivo da instabilidade do valor do preço prêmio pago ao produtor, sendo influenciado diretamente por fatores neoclássicos, como no caso da oferta e demanda, e fatores institucionais, como no caso da análise da reputação dos produtores.

\subsubsection{Etapa 6: Processo de Venda/Expedição da Soja até o Porto Utilizando o Modal Rodoviário}

Feita a armazenagem da soja, a próxima etapa do processo logístico é o de venda/expedição do produto. A Figura 4.7 mostra o fluxo de atividades que devem ser seguidas utilizando o modal rodoviário para o transporte, e onde deve haver maiores cuidados para evitar a contaminação. 
Figura 4.7: Etapa 6 - Processo de expedição da soja até o porto utilizando o modal rodoviário

Fonte: Elaborado pelo autor (2014)

O processo de expedição da soja convencional é mais demorado do que na soja transgênica, uma vez que há necessidade de se fazer a limpeza em todo o canal de expedição quando a soja é vendida, como a retirada da lona e o descarte da soja remanescente no armazém da soja transgênica. Importante ressaltar a relevância da limpeza das esteiras que irão fazer o transbordo do armazém para o caminhão. Novamente, é necessário que se faça o carregamento da soja convencional, em primeiro lugar, para reduzir os riscos de contaminação. Caso seja feito, primeiramente, o carregamento da soja transgênica, é necessário esperar o término de todo o processo para dar início ao processo da soja convencional, a fim de que não haja riscos de contaminação.

Geralmente, os produtores das cidades de Unaí-MG, Arinos-MG e Paracatu-MG enviam a soja segregada de sua fazenda até a empresa armazenadora/processadora SELECTA, a qual se encontra na cidade de Araguari-MG, via modal rodoviário. Depois que a soja é recebida e processada pela SELECTA, é utilizado o modal ferroviário para envio da soja até o porto para exportação. Porém, há produtores que segregam a soja e a envia diretamente para o porto, utilizando, para isso, apenas o modal rodoviário, sem passar por alguma empresa armazenadora/processadora ou utilizar outro modal de transporte.

\subsubsection{Etapa 7: Processo de Venda/Expedição da Soja até o Porto Utilizando o Modal Ferroviário}

A Figura 4.8 mostra o fluxo de atividades que devem ser seguidas utilizando o modal ferroviário como meio de transporte, além de mostrar as operações que merecem maiores cuidados para evitar a contaminação.

Primeiramente, é necessário fazer a limpeza em todas as máquinas e equipamentos para a expedição da soja livre de transgênicos. Depois que este processo é feito, a empresa deve contratar uma empresa terceirizada para a emissão do laudo sobre a carga, atestando a pureza do produto. Se acusar contaminação, a empresa não carrega a soja, 
ou envia a carga para outro porto que não faz a segregação da soja. Em caso de não contaminação, a empresa contrata o serviço do terminal ferroviário, cobra a limpeza minuciosa dos vagões, e faz limpeza minuciosa das esteiras que farão o transbordo da soja do armazém para o trem. Importante ressaltar que se os dois tipos de soja estiverem sendo carregados em vagões distintos próximos um ao outro, é necessário esperar o carregamento da soja transgênica para não correr o risco de contaminação. Finalizado o carregamento do trem, a soja é levada até o armazém no porto que faz a segregação da soja. 


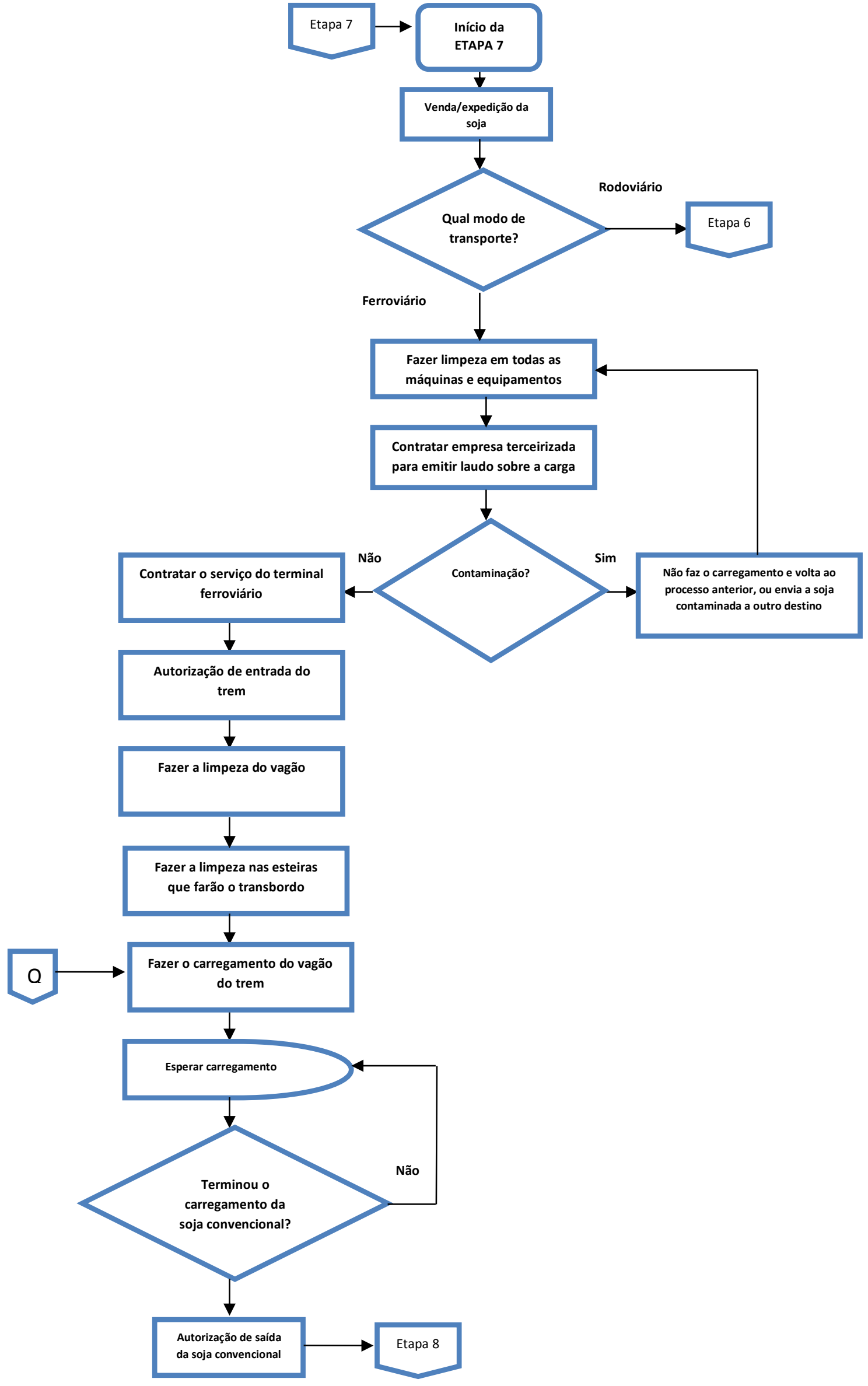

Figura 4.8: Etapa 7 - Processo de expedição da soja até o porto utilizando o modal ferroviário

Fonte: Elaborado pelo autor (2014) 


\subsubsection{Etapa 8: Processo de Armazenagem do Trem ou Caminhão no Porto que faz a Segregação da Soja}

A Figura 4.9 mostra o fluxo de atividades que devem ser seguidas no processo de armazenagem do trem ou caminhão que transportou a soja até o porto que faz sua segregação.

Pode ser observada, novamente, a contratação de uma empresa terceirizada para emitir o laudo sobre a carga atestando a qualidade do produto. Caso seja acusada transgenia, a soja é enviada para o espaço destinado ao armazenamento dos transgênicos e aguardará expedição para o navio. Importante ressaltar que em caso de contaminação não haverá pagamento de prêmios para o dono da carga.

Caso não seja acusada a transgenia, é necessário fazer uma limpeza minuciosa nas esteiras que farão o transbordo do caminhão ou do trem para o espaço destinado ao armazenamento da soja convencional. Depois que é feito este processo, a soja é armazenada e aguardará expedição para o navio. 


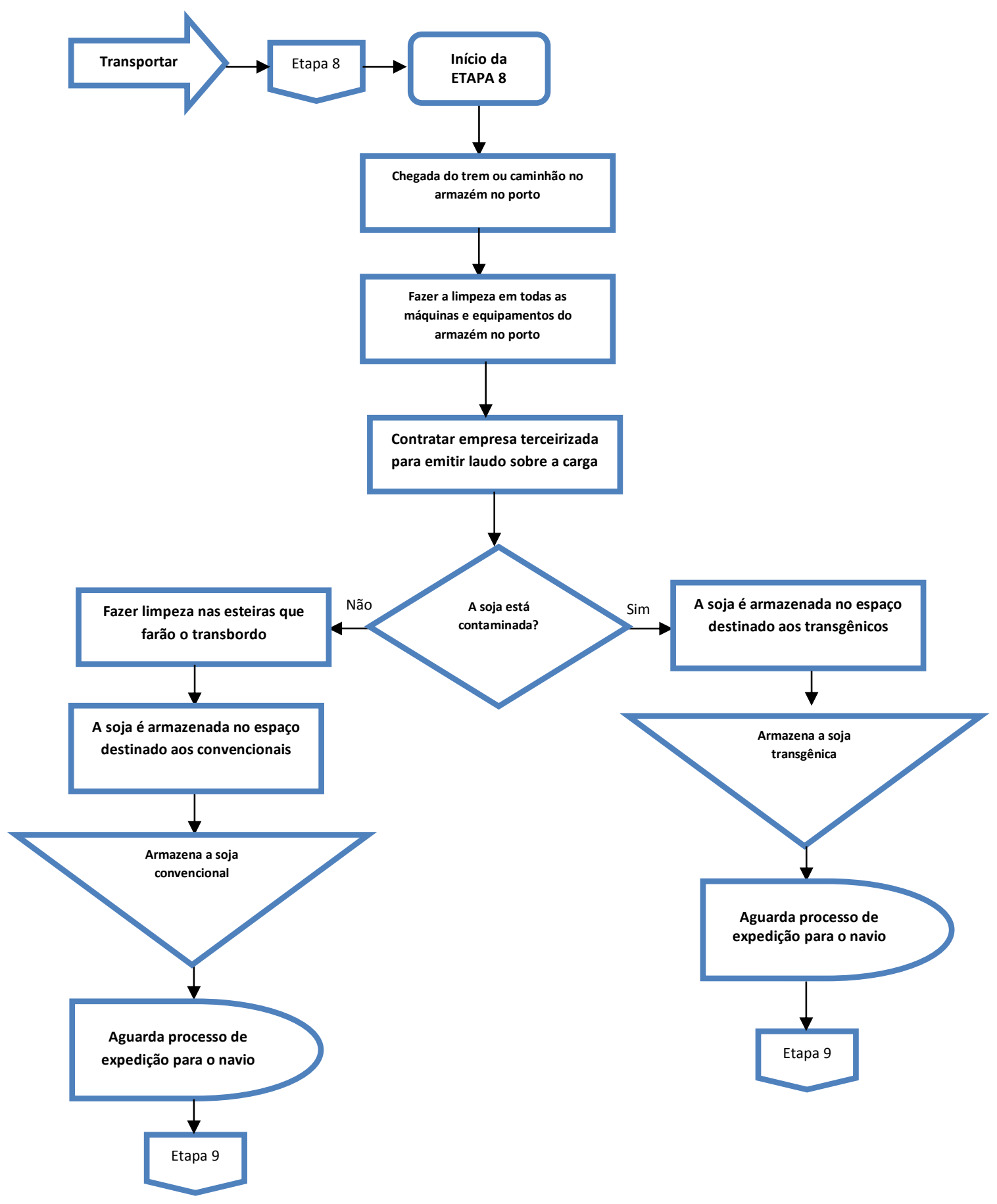

Figura 4.9: Etapa 8 - Processo de armazenagem do trem ou caminhão no porto que faz a segregação da soja

Fonte: Elaborado pelo autor (2014)

\subsubsection{Etapa 9: Processo de Expedição da Soja do Armazenagem no Porto para o}

Navio

A Figura 4.10 mostra o fluxo de atividades que devem ser seguidas no processo de expedição da soja no armazém do porto para o navio. 


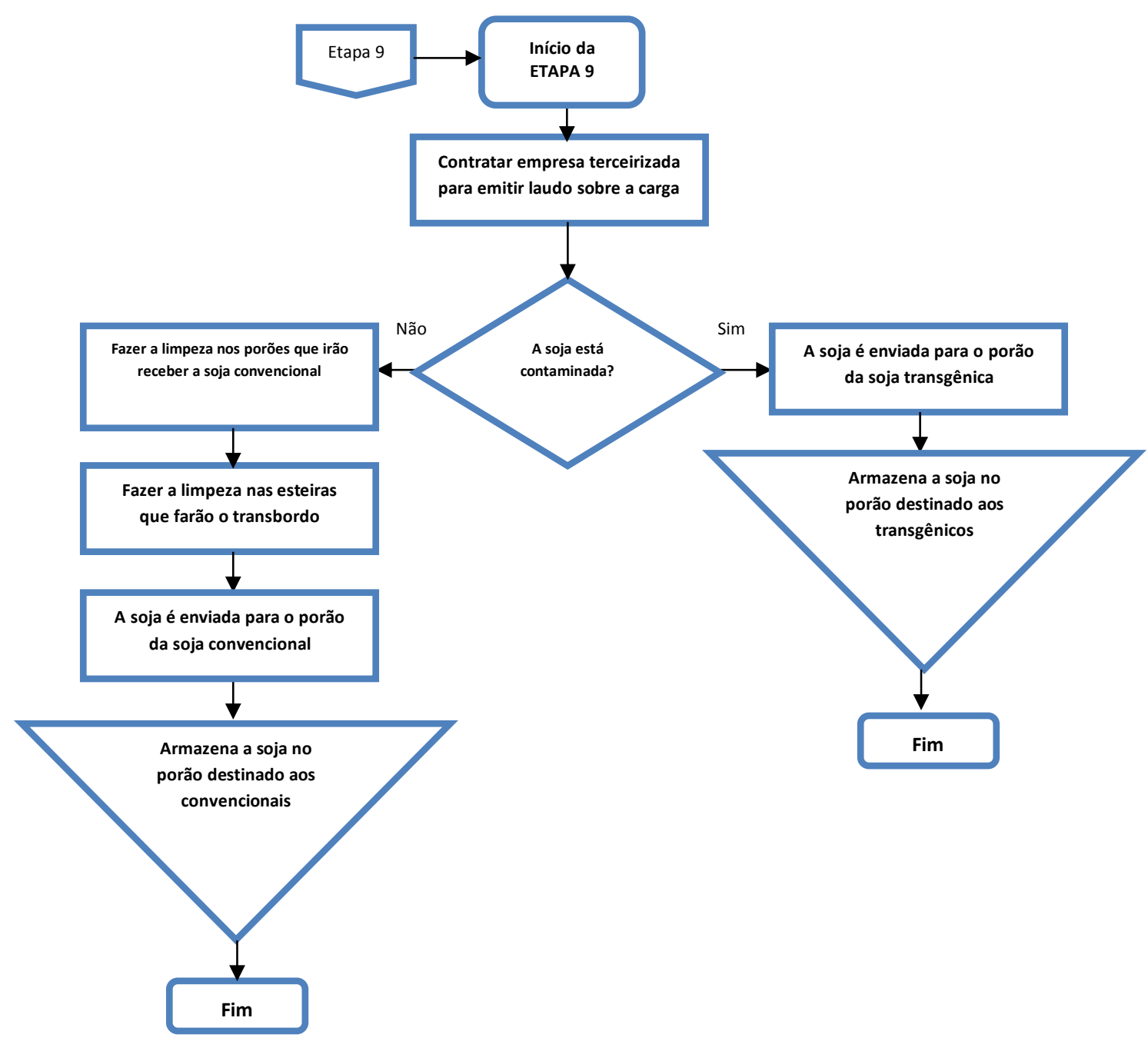

Figura 4.10: Etapa 9 - Processo de expedição da soja do armazém no porto para o navio Fonte: Elaborado pelo autor (2014)

Uma empesa terceirizada é novamente contratada para emitir o laudo sobre a pureza do produto. Caso haja contaminação, a soja é enviada para o porão destinado à armazenagem da soja transgênica. Caso contrário, é preciso fazer a limpeza minuciosa do porão que irá receber a soja convencional, e também das esteiras que farão o transporte do armazém para o navio. Feito isso, a soja poderá ser armazenada para ser enviada ao mercado internacional.

Sendo assim, todos os processos da cadeia logística da soja foram desvendados, desde o momento da compra dos insumos até o momento da expedição dos produtos no navio para exportação, mostrando que, realmente, na cadeia logística da soja convencional, deve haver maiores cuidados, em se comparando com a cadeia da soja transgênica, 
trazendo aumento nos custos pela necessidade da segregação. Estes custos serão mostrados no Capítulo 5.

\subsection{TRANSPORTADORES RODOVIÁRIOS}

As análises deste tópico foram extraídas de entrevistas realizadas com transportadoras das cidades de Unaí-MG, Paracatu-MG e Arinos-MG.

Todos os transportadores disseram trabalhar com os dois tipos de soja, sem restrições. Segundo eles, há uma dificuldade muito maior para se fazer o transporte da soja convencional, haja vista que lhes é cobrada uma limpeza minuciosa dos caminhões antes do carregamento, o que consome tempo e não traz nenhuma remuneração adicional pelo serviço prestado.

Cuidado muito grande deve ser observado também no transbordo do produto para não haver a contaminação. Algum caminhão que esteja carregado de soja transgênica pode jogar, involuntariamente, algum grão transgênico na carga quando a lona é descoberta, ou ainda haver a contaminação pelo pó que a soja solta quando é descarregada.

Os transportadores fazem os testes de transgenia quando o caminhão chega e sai dos armazéns, carregado de soja livre de transgênicos. Quando o caminhão sai da fazenda do produtor, somente são feitos os testes se estiver contratado para transportar soja livre de transgênicos. Os testes de transgenia atrasam a saída dos caminhões, sendo este um custo não recebido pelos transportadores. Caso o caminhão esteja carregado com soja transgênica, não é necessário fazer o teste de transgenia, agilizando o processo de expedição para o transportador.

A soja livre de transgênicos é transportada para lugares mais distantes que os habituais, pelo fato de que não há armazéns capacitados para fazer a segregação nos mercados em que atuam.

Para os transportadores, o saneamento do problema da contaminação da soja passaria pela exigência de contratos em todos os elos logísticos, com punição para quem contaminasse a soja ao longo da cadeia. Os transportadores informaram também que 
sempre são culpados de não terem feito a limpeza conforme os procedimentos necessários, quando ocorre a contaminação.

Um dos transportadores informou ser cobrado da empresa que contratou o seu serviço acerca da necessidade de uma lona especial em sua carroceria, de modo que não caia nenhum grão convencional no transporte da soja. Sendo assim, pode ser que haja a necessidade de uma embalagem diferenciada, trazendo um custo maior para o transportador, porque, nas próprias palavras do entrevistado, essa lona custa o dobro da lona tradicional.

Os transportadores não recebem um preço superior por transportar a soja convencional. Para os transportadores, a grande mudança trazida pelo advento dos transgênicos foi no processo de limpeza dos caminhões, o qual deve ser muito cuidadoso e rigoroso. Outra mudança ocorreu no carregamento/descarregamento da soja convencional, pois o processo é mais demorado, uma vez que o teste de transgenia atrasa sua saída. Os transportadores não podem também realizar a carga/descarga de caminhões com sojas transgênica e convencional, para que não haja a possibilidade de contaminação.

\subsubsection{Informações Adicionais sobre Transporte, Armazenagem, Transbordo e Testes de Transgenia na Cadeia Logística da Soja}

Este tópico trata, especificamente, das informações concedidas pelos produtores rurais. Tais informações estão relacionadas aos problemas dos transportes feitos por caminhões com os quais eles estão diretamente envolvidos.

Primeiramente, foi constatado junto aos produtores que o preço do frete da soja é o mesmo para a transgênica e convencional. Há a opção do SIF ou FOB. Importante ressaltar que quando há a necessidade de fazer a limpeza no caminhão seria justo pagar um preço superior para o transporte da soja convencional, o que motivaria os transportadores a terem maior cuidado no momento de fazer essa limpeza. Isso é de fundamental importância para a não contaminação da soja. Essa informação ratifica o que foi dito anteriormente, mostrando que não há diferença no preço do frete quando o transportador leva a soja convencional. Esse preço assume, no entanto, o custo adicional da limpeza, mostrando mais uma vez que a solução para esse problema seria que o valor 
adicional da limpeza fosse solicitado em contrato, para que houvesse maior incentivo e cuidado por parte do transportador nesse importante processo para a não contaminação.

O transporte da soja da fazenda do produtor até a empresa compradora é pago pela empresa compradora da soja livre de transgênicos, e a armazenagem na fazenda é paga pelo produtor.

Os produtores informaram que, quando há o carregamento da soja convencional, é enviado um classificador da empresa compradora (SELECTA) para fazer todos os testes com a soja. Segundo informações dos próprios produtores, a exigência maior é no momento da aferição de transgenia. Depois de feito o teste, o classificador emite um laudo dando seu parecer sobre a carga, incluindo nesse a contaminação ou não.

Quando os produtores optam por terceirizar o transporte, eles fazem o pedido para que se faça uma limpeza minuciosa nos caminhões. Estes produtores relataram, todavia, que quando os caminhões chegam às fazendas é constatada a falta de limpeza, com a presença de vestígios de grãos na carroceria ou nas tampas quando são abertas. Quando isso acontece, o produtor exige a limpeza, enquanto o gerente da fazenda acompanha todo o procedimento. Os produtores argumentaram ainda que, mesmo explicando para o transportador o possível problema de contaminação, muitos não entendem que ficando alguns resíduos de grãos transgênicos na carroceria, pode haver a contaminação de toda a carga.

Depois de feita toda a limpeza, e já com o caminhão carregado, é feito o teste de transgenia pelo classificador da SELECTA, que vem especificamente para fazer essas aferições. Os produtores informaram que não pode haver o carregamento dos dois tipos de soja ao mesmo tempo, porque se o fizer, pode ser que haja a contaminação, já que o pó do grão transgênico, cascas ou mesmo grãos podem, involuntariamente, ir para a carga da soja convencional. Eles disseram ainda que o ideal é fazer o carregamento da convencional, e posteriormente, a transgênica. Todavia, por dificuldades operacionais, nem sempre isso é possível.

Se no teste de transgenia for acusado mais de 1 grão em 1.000, a SELECTA fica desobrigada de fazer o carregamento da soja, e ainda cobra uma multa de $20 \%$ sobre o 
valor da venda do produto. O caminhão volta vazio para a empresa ou é desfeito o contrato naquele momento, podendo o caminhão voltar carregado de soja transgênica, caso haja interesse da empresa compradora. A SELECTA fica, nesse processo, desobrigada de fazer o pagamento do prêmio acordado.

Importante frisar que em todas as etapas em que a soja é carregada ou descarregada é necessário fazer novamente o teste de pureza do produto, para garantir que naquele trajeto feito pela soja não houve a contaminação.

No presente estudo, foi constatada a utilização de três modais para o transporte da soja até o seu destino (rodoviário, ferroviário e aquaviário). São necessários oito processos de transbordo, cinco armazenagens e sete testes de transgenia ao longo da cadeia logística para a garantia da pureza do produto.

É unânime entre os entrevistados que o transportador assumiu papel fundamental na garantia da não contaminação da soja, pois se a limpeza não for realizada minuciosamente, pode ser que fique resíduo de soja transgênica nas carrocerias, o que ocasionaria a possível contaminação.

\subsection{ARMAZENADORES/PROCESSADORES QUE FAZEM A SEGREGAÇÃO DA SOJA}

As análises dos resultados a seguir foram extraídas de entrevista feita com uma empresa armazenadora/processadora (SELECTA), a qual faz a total segregação da soja, transformando-a em farelo para venda no mercado internacional, recebendo prêmios por todo o custo despendido para fazer a separação das sojas em seus armazéns. A SELECTA paga prêmios aos produtores que conseguem entregar a soja livre de transgênicos em sua indústria.

As análises apresentadas estão subdividas em subcapítulos para melhor compreensão e entendimento dos principais pontos relacionados à segregação da soja. 


\subsubsection{Prêmios e Contratos Feitos Pelos Armazenadores/processadores}

O armazenador/processador entrevistado informou receber prêmios pela venda do produto livre de transgênicos no mercado internacional. Disse ainda que está pagando prêmios para os produtores que conseguem entregar o produto GMO FREE em suas unidades receptoras. Relatou também que paga prêmios para os operadores portuários pelos cuidados que devem ser tomados na segregação da soja no porto. Porém, não paga prêmios para os transportadores rodoviários e operadores ferroviários para fazer a segregação.

O entrevistado informou que o valor do prêmio pago para os produtores e operadores portuários oscila muito ao longo do ano, dependendo das demandas dos países que a exigem e do valor do contrato fechado por saca de soja no mercado internacional. Sendo assim, o valor do prêmio pago para a cadeia está diretamente relacionado com o valor do prêmio que o mercado internacional terá interesse em pagar pela saca de soja segregada entregue pelos armazenadores/processadores, segundo informações destes agentes.

O entrevistado disse que faz contratos com os três agentes (comprador no mercado internacional, produtor rural e operadores portuários), com os quais transacionam, e relatou que os contratos formais são a única forma de conseguir fazer cumprir o que é acordado entre as partes, principalmente no que tange à necessidade de segregação ao longo da cadeia logística e a entrega do produto livre de transgênicos. Foi categórico ao dizer que se não houvesse o contrato, servindo como mecanismos de incentivo, dificilmente os agentes teriam motivação para fazer a segregação da soja. Ele ainda afirmou que: "já tentamos fazer contratos informais com os produtores, com base na confiança para com estes, porém, sempre que era acusada a transgenia no teste, o produtor se isentava do problema, dizendo que a contaminação aconteceu em outras etapas que não em sua fazenda, ficando muito difícil executar o contrato por não ter formalidade, tendo o armazenador/processador que fazer o pagamento do prêmio ao produtor, e ainda não recebê-lo do mercado internacional, agentes estes que não aceitam o contrato informal'. 
O armazenador/processador também é o responsável pelos cuidados que devem ser tomados para a não contaminação nas operações de transporte rodoviário da fazenda do produtor até sua empresa, e do transporte ferroviário da sua empresa até o porto de destino da soja. Porém, disse não fazer contrato formal com nenhum destes agentes, pagando apenas o frete pelo serviço prestado. Sendo assim, caso haja a contaminação em algum desses processos logísticos, os operadores de transporte rodoviário e ferroviário não poderão ser penalizados contratualmente, porque não há um contrato formalizado que puna a possível contaminação que possa emergir.

Para não haver contaminação nesses processos logísticos, o armazenador/processador informou que para todos os carregamentos de soja feitos na fazenda do produtor, são enviados funcionários (chamados de classificadores) para aferir a limpeza dos caminhões e fazer os testes de transgenia antes do carregamento do caminhão. Informou também fazer o mesmo processo no terminal ferroviário, com um funcionário responsável para a aferição da limpeza dos vagões do trem e dos testes de transgenia, antes de seu carregamento com destino ao porto.

\subsubsection{Riscos de Contaminação e Estratégias de Segregação do Armazenador/processador da Cadeia Logística da Soja}

$\mathrm{Na}$ entrevista com o agente armazenador/processador, foi observado que a empresa recebe os dois tipos de soja em seus armazéns. Como estratégia de segregação, cada tipo de soja vai para uma célula diferente de armazenagem. $\mathrm{O}$ agente afirmou que seus custos aumentaram consideravelmente, por ter que fazer essa segregação no armazém, além de ter de fazer um investimento muito grande na construção de uma unidade exclusiva para a recepção da soja livre de transgênicos.

Essa empresa possui um programa para fazer a segregação da soja em suas unidades, chamado de "Programa NON GMO", que tem como objetivo garantir a qualidade e certificar a fabricação de produtos não transgênicos. A empresa informou que, por meio de um rigoroso sistema de rastreabilidade, todo o processo produtivo é verificado, desde a origem das sementes, acompanhamento, plantio, desenvolvimento vegetativo das

plantas e da colheita, armazenagem, logística, processamento nas indústrias, transporte até a entrega do produto final no Brasil e no mundo. 
Para cumprir os requisitos do programa de rastreabilidade, as fábricas realizam uma série de auditorias, inspeções, testes, controles e análises em diferentes estágios do processo de produção e beneficiamento, logística, armazenagem e embarque. Todos estes processos são feitos, separadamente, em análises laboratoriais, com testes rápidos (enzimáticos) das sementes, das folhas no campo e da soja - a qual é analisada antes de ser recebida nos armazéns e na indústria, assegurando a descarga somente de lotes com resultados negativos.

São realizadas também análises de PCR (Polymerase Chain Reaction) da soja, farelos e lecitina no processo industrial e dos farelos de soja HiPro e peletizado no recebimento dos armazéns, dos portos e nos embarques nos navios. Os produtos ofertados por essa empresa para exportação são: lecitinas de soja, farelo de soja peletizado e farelo HiFiber.

Sobre os cuidados e procedimentos realizados por eles para fazer a segregação da soja GMO FREE nos armazéns, foi relatado que todo o produto é classificado, e é feita a inspeção de qualidade na origem de embarque (na fazenda do produtor). Depois, é feito o teste novamente quando a soja chega à indústria. Nesta classificação/inspeção, eles identificam se há transgenia ou não. Feito isso, a soja é carregada/descarregada e faz-se o direcionamento para a unidade de armazenamento pertinente.

Quando chega soja no armazém de um produtor que não é contratado pela empresa para pagamento de prêmios, eles fazem o teste de transgenia apenas na entrada do armazém, mas não há pagamento de prêmios, por não ter feito contrato formalizado com os produtores que a entregam.

Para fazer a total segregação da soja nos armazéns, a empresa informou ter uma unidade receptora exclusiva para a soja convencional e outra para a soja transgênica, ou seja, não fazem a segregação do produto dentro de um mesmo armazém e sim em unidades separadas. 
O entrevistado não quis revelar para quais países essa soja é enviada, porém, há fortes indícios de que ela é expedida para alguns países da Ásia, emblematicamente para o Japão e a Coréia, ou para outros países da Europa.

Segundo informações do entrevistado, o local que acredita ter maiores riscos de contaminação da soja ao longo da cadeia é no plantio e na colheita, pelo fato de os produtores não fazerem a limpeza das máquinas/equipamentos conforme deve ser feito.

Quanto aos investimentos específicos para fazer a segregação nos armazéns, estes são feitos nas instalações físicas, notadamente nos armazéns, haja vista a necessidade da construção de um novo armazém para receber a soja livre de transgênicos. Os demais itens, como as esteiras, pré-limpeza etc., podem ser utilizados para as duas sojas, porém com muito cuidado na hora de se fazer a limpeza. Para isso, a empresa teve de capacitar todos os seus funcionários para se conscientizarem da importância deste procedimento e garantir que não haja a contaminação dentro da indústria.

A empresa entrevistada informou não ser necessário ter uma embalagem diferenciada para a soja GMO FREE. Sendo assim, não há aumento dos custos logístico neste processo específico ligado à logística.

Além dos altos custos com o investimento em um armazém exclusivo para recebimento da soja livre de transgênicos, a empresa informou ter problemas com a ociosidade dos armazéns para fazer a segregação. Disse ainda que a baixa quantidade de soja convencional produzida no Brasil dificulta muito a gestão dos armazéns. Isso está patente quando o entrevistado diz que: "o grande volume a receber/movimentar é da soja transgênica, e caso se queira ganhar o prêmio é necessário fazer a segregação, e essa segregação custa mais espaço físico, tendo que às vezes deixar os armazéns receptores de soja convencional vazios por falta de produtores que não conseguem entregar o produto GMO FREE”.

O entrevistado relatou também que a soja GMO FREE é vendida mais rapidamente, por já ter contratos amarrados com os países que a demandam, fazendo com que aumente ainda mais a ociosidade dos armazéns. 
De acordo com os entrevistados, a única possibilidade de acabar com essa ociosidade seria conseguir mais produtores que entregassem soja GMO FREE em seus armazéns, aumentando, assim, a possibilidade de se trabalhar com a capacidade ótima. Porém, como a maioria dos produtores trabalha com soja transgênica, e como grande parte dos que trabalham com soja convencional não consegue fazer a segregação em suas propriedades, em razão dos altos investimentos em ativos específicos, este problema certamente continuará a ser patente por muito tempo.

A empresa entrevistada informou que qualquer produtor pode entregar soja livre de transgênicos em seu armazém. Porém, é feita uma pesquisa de mercado para saber da reputação dos produtores que são mais "confiáveis" e que conseguem entregar a soja sem contaminação. Há um cadastro com o histórico de cada produtor que já fez algum tipo de transação com a empresa, inclusive com informações de todos os problemas/ocorrências de entrega de soja contaminada para a empresa armazenadora/processadora.

O entrevistado informou que alguns armazenadores/processadores concorrentes (BUNGE, ADM, CARGIL, dentre outras), para não fazer todos os investimentos feitos pela SELECTA, utilizam estratégias diferenciadas de segregação da soja. Segundo ele, essas empresas utilizam como estratégias descobrir com antecipação qual a proporção de soja geneticamente modificada e GMO FREE que eles irão receber em seus armazéns em determinada safra.

Para tanto, é feita uma visita periódica nas propriedades de seus clientes dois meses antes de começarem a receber a soja, a fim de saber qual das duas opções o produtor está plantando mais. A partir daí, traçam suas estratégias de fazer ou não segregação, dependendo do volume que será oferecido pelos produtores. Se a quantidade de transgênicos for muito menor que a convencional, aquela armazenadora/processadora, situada em determinada região, dará preferência para recebimento exclusivo de soja convencional, não recebendo soja transgênica em seus armazéns. Caso a proporção de soja transgênica seja superior à da convencional, a empresa opta por não fazer a segregação, recebendo os dois tipos de soja. Neste caso, há a mistura em seus armazéns, e não há pagamento do prêmio ao produtor que entrega soja livre de transgênicos. 
Há assimetria de informação no que foi relatado na primeira opção citada anteriormente por parte das armazenadoras/processadoras para com os produtores. Isso porque quando tal fato ocorre com os armazenadores/processadores, não há pagamento de prêmios para os produtores, mas sim a segregação da soja convencional e a entrega do produto livre de transgênicos no mercado internacional. Nesse caso, os armazenadores/processadores recebem o prêmio, mas não o repassam ao produtor. Pelo fato de os produtores não saberem realmente o que está acontecendo, acabam "aceitando" essa condição.

Quando a empresa opta por receber somente soja livre de transgênicos, é feito o teste de transgenia na entrada da soja nos armazéns. Caso acusada a contaminação, a empresa simplesmente não recebe a soja, destinando-a para outro armazém filial ou ficando a critério do produtor tomar a decisão de qual local destinar. Caso não acusada a transgenia, a empresa recebe a soja, porém o seu destino de armazenagem dependerá do teste SGS (1 grão em 1000). Esse teste, então, é feito, e classificará a soja como GMO FREE, caso seja negativo, menos de 1 grão em 1.000. Caso esse teste seja positivo, ou seja, acusado mais de 1 grão em 1.000, a soja é destinada para um armazém de sua filial e será armazenada junto da transgênica. Se esse teste der negativo, a soja é armazenada na unidade receptora e, posteriormente, será expedida para o mercado internacional, recebendo o prêmio pela segregação. Porém, não pagam o prêmio para o produtor que entregou a soja GMO FREE (oportunismo pela assimetria de informação). Esse, talvez, seja um dos grandes oportunismos percebidos na pesquisa de campo com os armazenadores/processadores.

Todo o processo mencionado anteriormente pode ser visualizado na Figura 4.11. São estratégias de segregação utilizadas por armazenadores/processadores que não utilizam a mesma unidade para receber os dois tipos de soja. 


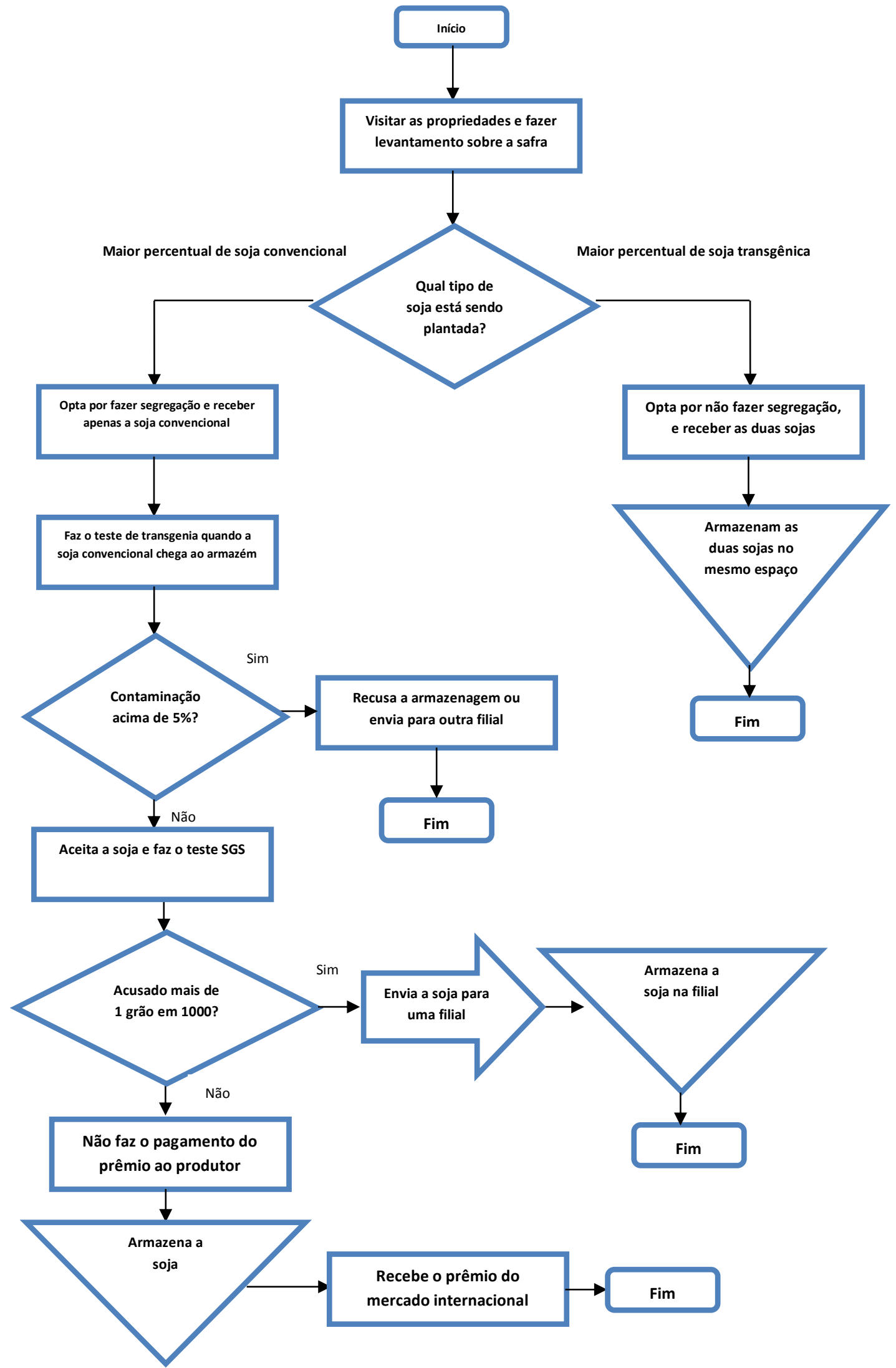

Figura 4.11: Estratégias de segregação utilizadas por armazenadores/processadores que utilizam duas unidades para receber os dois tipos de soja.

Fonte: Elaborado pelo autor (2014)

A segregação citada na Figura 4.12 define quais unidades das empresas armazenadoras/processadoras vão receber soja geneticamente modificada, e quais vão receber soja GMO FREE. Assim, ao invés de trabalhar com duas linhas de recepção 
para segregação numa mesma unidade armazenadora, separa-se cada unidade armazenadora para receber um tipo de soja, geneticamente modificada ou GMO FREE. As unidades armazenadoras são totalmente independentes umas das outras, com possibilidade de $100 \%$ de segregação. No pátio dos armazéns, são feitas varreduras assim que a soja é despachada. Todos os resíduos remanescentes vão para a unidade armazenadora de soja transgênica.

Quando a soja chega ao armazém, o produtor deve informar qual é a categoria de soja. Se o produtor declarar que o produto é transgênico, então não é necessário fazer o teste de transgenia. Se for declarado convencional, faz-se o teste imediatamente.

Normalmente, são feitas duas amostragens para cada caminhão ou outra forma de transporte. Para saber se a soja é transgênica ou convencional são feitos dois tipos de testes. O chamado teste da Monsanto para o recolhimento dos royalties, cujo teste permite uma tolerância de até $5 \%$ de transgênicos, limite acima do qual se determina a obrigatoriedade de pagamento do royalty sobre toda a carga/caminhão. O segundo teste é realizado por uma empresa certificadora terceirizada, mediante a qual a soja só é considerada convencional se a presença de grãos transgênicos for inferior a $0,1 \%$ (1 grão em 1.000), também denominado teste de presença adventícia (PA) ou teste SGS. Se o índice ultrapassar esse limite, a soja é destinada para a unidade armazenadora de transgênicos.

O teste de PA, feito pela empresa SGS Brasil, determina a exigência de eventos transgênicos na soja, sendo essencial para fornecer ou comercializar grãos e sementes, baseado no fato de elas não possuírem organismos geneticamente modificados ou baixos níveis de organismos geneticamente modificados (SGS, 2014). Segundo a própria empresa, esse teste garante a conformidade com as regulamentações nacionais e internacionais apropriadas e gera confiança no mercado, reduzindo seus riscos operacionais (SGS, 2014). Depois que o teste é realizado, emitindo-se um laudo de responsabilidade técnica atestando a pureza do produto. O custo do teste SGS é arcado pela própria armazenadora/processadora.

Outro problema que os armazenadores/processadores têm enfrentado depois do advento dos transgênicos diz respeito à contaminação das sementes. $\mathrm{O}$ entrevistado informou 
que houve muitos casos de contaminação nas variedades das sementes fornecidas para os produtores. Segundo ele, como na maioria das vezes as sementes utilizadas pelo produtor são fornecidas pela própria armazenadora/processadora, manteve-se o pagamento do prêmio para esses produtores.

Depois que a soja chega ao armazém, essa é transformada em farelo. Depois, o farelo de soja é armazenado, e fica aguardando sua venda/expedição.

No processo de expedição, é necessário novamente ter todo o cuidado com o farelo de soja convencional. Para isso, há um terminal ferroviário que passa dentro das instalações da empresa SELECTA.

No processo de expedição, a SELECTA tem de fazer a limpeza de todas as máquinas e equipamentos, principalmente das esteiras que fazem o transporte do farelo até o vagão do trem. Para atestar que a soja não tem nenhum tipo de contaminação, a SELECTA é obrigada a contratar uma empresa terceirizada, que emite um laudo de pureza do produto antes de sua saída do armazém. Só depois disso, é iniciado o processo de transbordo do armazém para o trem. Se o laudo for negativo, a SELECTA tem de fazer novamente todo o processo de limpeza e contratar a empresa terceirizada para a emissão de novo laudo. Caso o farelo esteja realmente contaminado, a SELECTA envia o produto para outro destino.

É responsabilidade também da SELECTA fazer toda a limpeza no vagão do trem no qual será transportada a soja livre de transgênicos. Eles selecionam um vagão (de preferência um que esteja mais distante de vagões que estão carregados com soja transgênica) para armazenar o farelo de soja convencional. Feita toda a limpeza, o farelo é colocado no vagão e segue até o armazém do porto de Tubarão, no Espírito Santo.

Quando o farelo de soja chega ao armazém do porto de Tubarão, o transbordo é feito por uma esteira. Novamente, todo o processo de limpeza deve ser realizado em todas as máquinas e equipamentos para garantir que não haja contaminação do produto.

Esse armazém recebe os dois tipos de soja e há uma segregação interna dentro dele para a recepção do farelo de soja convencional. O armazém do porto de Tubarão é alugado 
pela SELECTA, que faz todo o processo de limpeza para garantira pureza do produto. No armazém do porto de Tubarão, é feito novamente o teste de transgenia por uma empresa terceirizada, a qual emite, novamente, o laudo sobre a carga. Se acusada a transgenia, a carga é desqualificada e armazenada junto da soja transgênica. Em caso contrário, a carga segue para o espaço reservado para a recepção da soja convencional.

No carregamento da soja no navio, é feito, novamente, o teste de transgenia, e também a limpeza nas esteiras que fazem o transbordo do armazém para o navio. Outro laudo é emitido para atestar a qualidade da carga, a qual é carregada e enviada para exportação. Caso o laudo acuse a transgenia, o farelo de soja é colocado em um porão de soja transgênica, caso contrário a soja seguirá para um porão que recebe apenas farelo de soja pura.

A Tabela 4.1 traz um resumo das principais mudanças na cadeia logística da soja para o armazenador/processador após o advento e difusão dos transgênicos.

\section{Tabela 4.1: Principais mudanças na cadeia logística da soja sob a ótica do armazenador/processador}

\begin{tabular}{|c|c|}
\hline Prêmios & $\begin{array}{l}\text { 1-Recebe prêmios do mercado internacional; 2-Paga prêmios para os produtores e } \\
\text { operadores portuários; } 3 \text {-Não paga prêmios para os transportadores rodoviários e } \\
\text { ferroviários; } 4 \text {-Se acusado } 1 \text { grão em } 1.000 \text { no teste de transgenia, não há pagamento } \\
\text { de prêmio e pode executar o contrato. }\end{array}$ \\
\hline $\begin{array}{l}\text { Riscos de } \\
\text { Contaminação }\end{array}$ & 1-Semente; 2-Transporte; 3-Armazenagem; 4-Transbordo. \\
\hline $\begin{array}{l}\text { Estratégias de } \\
\text { Segregação }\end{array}$ & $\begin{array}{l}\text { 1- Ter duas unidades receptoras, uma para cada tipo de soja; 2- Limpeza minuciosa } \\
\text { em todas as máquinas e equipamentos no armazém; 3-Cursos de capacitação para } \\
\text { todos os funcionários; 4-Cobrar dos transportadores rodoviários e ferroviários a } \\
\text { limpeza minuciosa dos seus caminhões e vagões, porém, não paga prêmio nem frete } \\
\text { diferenciado. }\end{array}$ \\
\hline Contratos & $\begin{array}{l}\text { 1- Faz contratos com a Monsanto para recolhimento de royalties; } 2 \text {-Faz contrato de } \\
\text { venda com os países importadores; } 3 \text {-Faz contrato com os produtores; } 4 \text {-Faz } \\
\text { contrato com um armazém próximo ao porto; } 5 \text {-Faz contratos com os operadores } \\
\text { portuários. }\end{array}$ \\
\hline
\end{tabular}

Fonte: Elaborado pelo autor (2014)

A próxima etapa da cadeia logística refere-se às atividades desenvolvidas pelos portos.

A seguir, serão apresentados os riscos de contaminação nos portos e as principais estratégias utilizadas por eles para fazer a segregação da soja. 


\subsection{PORTOS QUE FAZEM A SEGREGAÇÃO DA SOJA}

As informações tratadas a seguir foram extraídas de entrevistas feitas com dois operadores portuários que informaram fazer todo processo de segregação no porto onde operam, um no Estado de Espírito Santo (porto de Tubarão), e outro no Estado do Paraná (porto de Paranaguá).

Procurou-se identificar o que é feito com a soja livre de transgênicos depois que ela chega ao armazém do porto, bem como todos os cuidados e procedimentos que são adotados para que não haja a contaminação do farelo de soja, desde seu transbordo até a expedição do produto ao mercado internacional.

Previamente, o Centro de Controle Operacional (CCO) recebe a oferta de vagões para descarga, detalhada por cliente e produto. Em seguida, é visualizada a disponibilidade de espaço nos armazéns e disponibilizado o programa de descarga diário para a Operação Porto e Ferrovia. No porto de Tubarão, há 9 armazéns para descarga, onde o sistema de transportador limita a descarga em apenas um armazém e célula (segurança contra contaminação de carga). Para produtos segregados, neste caso o farelo da soja convencional, há necessidade de limpeza de rota (todas as máquinas e equipamentos envolvidos no processo de recebimento, armazenagem e expedição do farelo de soja), tanto para a descarga quanto para o embarque.

Para realizar a total segregação, os entrevistados informaram que existem duas moegas que recebem os lotes de vagões independentes para a descarga do grão. Segundo o entrevistado do porto de Paranaguá, os maiores cuidados para garantir a não contaminação da soja devem ser tomados no processo de descarga dos caminhões e dos vagões.

No porto de Paranaguá, o maior cuidado informado pelo entrevistado foi o de não passar soja transgênica por cima da soja GMO FREE, pois, possivelmente podem cair grãos que contaminariam a soja convencional. Outra estratégia importante, citada pelo operador do porto de Paranaguá, é o total isolamento do espaço em que está armazenada a soja GMO FREE. Esse isolamento é feito com o uso de paredes entre os lotes nos 
armazéns e com lona estendida sobre o produto convencional, a fim de se evitar a contaminação pelo pó.

Os entrevistados afirmaram que o sistema é seguro quanto à possibilidade de contaminação, mas os maiores riscos estão em possíveis falhas de automação dos armazéns para embarque, podendo ocorrer abertura de comportas de dois armazéns ao mesmo tempo, o que geraria a contaminação da carga. Também citaram falhas humanas.

Basicamente, as máquinas e equipamentos utilizados para fazer o transbordo da soja do trem para o armazém e do armazém para o navio são:

DESCARGA: duas moegas para descarga de vagões, transportadores e nove armazéns separados em células.

EMBARQUE: uma linha de correia transportadora, duas balanças de batelada e quatro carregadores de navios, sendo o embarque realizado um por vez.

As máquinas e equipamentos utilizados para fazer o transbordo e o manuseio dos dois tipos de soja são os mesmos, porém é necessário que seja feita a limpeza nestes equipamentos.

Através da entrevista com os operadores portuários foi possível identificar que essa soja livre de transgênicos tem como destino os seguintes países: Coréia do Sul, Japão, Suíça, França, Holanda, Singapura, Indonésia, Grã-Bretanha e Alemanha. A maior quantidade é destinada para a Holanda.

Também há necessidade de se fazer a segregação nas máquinas e equipamentos no armazém do porto. $\mathrm{Na}$ opinião dos entrevistados, para o farelo especial (livre de transgênicos) há a necessidade de segregação (há células específicas em armazéns), a limpeza é mais detalhada, feita com ar comprimido em todos os equipamentos. Não podem sobrar resíduos de outros produtos para a movimentação de farelo especial. Importante ressaltar que existe legislação que regula impurezas do produto, aferidos pelo padrão ANEC (Associação Nacional dos Exportadores de Cereais) (ANEC, 2014). 
Os contratos determinam a pureza necessária para que a soja possa ser embarcada. $\mathrm{Na}$ opinião dos entrevistados, os produtos especiais, como é o caso do farelo de soja livre de transgênicos, somente são despachados com sucesso porque há contratos que conseguem dar conta de fazer cumprir a segregação do produto ao longo da cadeia, com cláusulas que penalizam aqueles que contaminarem a soja com o não recebimento do prêmio.

Os entrevistados informaram que utilizam o mesmo armazém para colocar os dois tipos de sojas. Porém, a soja especial (pura) é colocada em um silo separado dos outros produtores. Eles relatam que o produto especial é tratado segregado. Soja, milho e farelo transgênicos são armazenados em um mesmo pool, ou seja, em um mesmo armazém e célula.

Dentro do navio, os maiores cuidados para evitar a contaminação do farelo de soja livre de transgênicos são praticamente os mesmos cuidados tomados para os outros produtos (soja, milho, farelo especial e comum). Porém, para a descarga e embarque, o tempo e necessidade de limpeza dos equipamentos são diferenciados para o farelo de soja especial. Geralmente, o navio vai carregado com os dois tipos de farelo de soja, o transgênico e o convencional. Todavia, isso ocorre em porões diferentes e com todo o cuidado para que não haja a contaminação. Há também a necessidade de fazer toda a limpeza nos porões que irão carregados com o farelo de soja livre de transgênicos.

São realizados testes de pureza do farelo da soja em todos os vagões que chegam aos armazéns do porto de Tubarão. As avaliações fazem amostragem em todas as cargas dos vagões que chegam a Tubarão e o controle de qualidade é feito no embarque, para garantir que o produto esteja dentro dos parâmetros de qualidades exigidos pelos padrões ANEC. Importante ressaltar também que há controladoras dos clientes que acompanham a descarga e embarque do produto no Porto para saber se não haverá nenhum tipo de contaminação por parte do operador portuário, pois quando a soja chega ao país de destino a responsabilidade passa a ser do comprador.

No porto de Paranaguá, os testes normalmente são feitos por comprador e vendedor. Quando é acusada a transgenia, normalmente o produto é destinado para um local de 
armazenagem de soja transgênica e toda a soja que tinha sido segregada até este ponto é misturada com a transgênica.

Para fazer a segregação do farelo de soja especial da soja transgênica no interior do navio, é necessário que sejam embarcados em porões separados. Para troca de produto (quando o porão foi armazenado com farelo de soja transgênica e será armazenado com soja convencional), há a necessidade de limpeza de todo o canal de expedição de forma bastante criteriosa. A limpeza dos porões é realizada pelo próprio navio e validada pelo Ministério da Agricultura, antes do início do embarque. As normas de todo esse processo, são regulamentadas pela ANEC. O operador portuário entrevistado informou que os contratos que regulamentam os processos supracitados são o ANEC 41, ANEC 43 e ANEC 71.

No porto de Paranaguá, faz-se necessária a limpeza de todas as máquinas e equipamentos. Segundo a fonte entrevistada, é necessária a limpeza de todos os equipamentos, desde pás carregadeiras, elevadores, correias transportadoras, espaço físico do armazém, enfim tudo. Quando o processo passa do convencional para o transgênico, a limpeza é desnecessária.

Finalmente, foi perguntado para os operadores logísticos se eles fazem algum tipo de contrato que os motivam a fazer a segregação do produto e posterior envio ao mercado internacional. Os dois entrevistados informaram fazerem contratos com um valor interessante, o que justificaria os custos pela segregação. Isso mostra, mais uma vez, a importância do papel dos contratos na coordenação da cadeia logística da soja.

\subsection{AGENTES QUE NÃO FAZEM A SEGREGAÇÃO DA SOJA}

As informações a seguir foram extraídas de entrevistas realizadas com agentes que faziam a segregação da soja, mas deixaram de fazê-la, e tiveram o intuito de identificar as causas para essa desistência. Procurou-se também conhecer a opinião dos atores em relação às mudanças na cadeia logística advindas da adoção da tecnologia dos transgênicos. 
Os resultados foram extraídos de entrevistas com 3 armazenadores/processadores, 3 transportadoras e 10 produtores rurais nas cidades de Unaí-MG, Buritis-MG, ArinosMG e Paracatu-MG.

\subsubsection{Produtores Rurais}

Todos os produtores entrevistados afirmaram ser extremamente difícil fazer a segregação da soja em suas fazendas, principalmente pelo fato de não terem armazéns para colocar seu produto após a colheita. O problema se agrava ainda mais por não haver armazéns públicos que segregam a soja nas cidades produtoras. Assim, o produtor opta pela produção da soja transgênica, uma vez que não receberá o prêmio pela soja convencional, ou terá que enviar o produto para outra cidade, tendo que arcar com a diferença do preço do frete.

Devido a isso, todos os produtores entrevistados informaram que migraram para quase $100 \%$ de seu plantio para a soja transgênica, não pelos resultados econômicos que essa pode trazer, mas por não terem condições de realizar a segregação.

Segundo os entrevistados, se quisessem fazer a segregação, teriam que tomar todos os cuidados no plantio, na colheita e na armazenagem, em todas as fases do processo, desde a compra da semente até a saída da soja da fazenda. Depois desse procedimento, e imediatamente após a colheita, deveriam enviar a soja a um armazenador/processador (fora da cidade) que tivesse condições de fazer a segregação.

Como não possuem armazéns em suas propriedades, eles poderiam, eventualmente, fazer a segregação somente nos processos que precedem a armazenagem. Entretanto, os produtores não sabem ao certo quando irão colher a soja convencional, sendo assim, ficaria difícil fechar contratos com a armazenadora/processadora, especificando o dia exato para o envio da soja, sem necessariamente ter que estocá-la em sua propriedade.

Os produtores sabem que a entrega da soja livre de transgênicos proporciona o recebimento de um preço prêmio. Para eles, o recebimento desse prêmio seria compensatório pelo custo da segregação. 
Todos os produtores informaram haver possibilidade de contaminação da soja no transporte, armazenagem e no transbordo da soja. Apenas um produtor informou não acreditar na contaminação em alguma dessas etapas logísticas. Há grande possibilidade de contaminação da soja no plantio e na colheita do produto, caso não haja cuidado com máquinas e equipamentos, principalmente no que tange à sua limpeza. Outro problema diz respeito aos problemas de contaminação na compra da semente, pois sempre há alguma semente transgênica misturada com a convencional, o que ocasiona o nascimento de plantas transgênicas junto com as convencionais.

Todos os produtores entrevistados concordam com a criação de uma cadeia exclusiva para a soja convencional, separando todos os ativos (transporte, armazém, silos, máquinas e equipamentos). Outra estratégia para fazer a segregação citada por eles foi a de utilizar os mesmos ativos para as duas sojas, porém, tendo maior cuidado com a gestão dos equipamentos e com sua limpeza; ainda assim, haveria algum risco de contaminação.

Para os produtores, é relevante a confecção de contratos formais entre os agentes com os quais têm transações para estabelecer punições àqueles que contaminassem a soja ao longo cadeia. A rastreabilidade foi citada como uma solução destes problemas da segregação; no entanto, os produtores sabem que sua implantação iria aumentar consideravelmente os custos logísticos de toda a cadeia. Apenas um produtor informou não ser importante a formalização de contratos para garantir a segregação da soja.

Para os produtores, a aquisição de insumos necessários para a produção dos dois tipos de soja ficou dificultada.

Os produtores informaram que não há diferença de preço de frete entre a soja transgênica e a convencional.

Dos 10 produtores entrevistados, oito informaram acreditar que a segregação da soja agrava ainda mais os problemas de falta de armazéns para o Brasil. Isso ocorre, porque a pouca quantidade de armazéns em nosso país limita as empresas armazenadoras/processadoras de fazerem a segregação em suas unidades, pois elas teriam que construir outro armazém específico para a recepção da soja convencional, 
ficando muito dispendioso, e não sendo compensatório para elas o valor do prêmio recebido.

Dentre os procedimentos citados pelos produtores para realizar a segregação da soja, está a escolha da área mais propícia para o cultivo da soja convencional. Todos os entrevistados afirmaram ser extremamente relevante esta prática. Os argumentos levantados seriam que as áreas mais distantes deveriam ser destinadas para a soja transgênica, uma vez que caminhões, máquinas e equipamentos não precisariam percorrer toda a lavoura para fazer a colheita da soja convencional, aumentando o risco de contaminação.

Depois que a área é escolhida, a próxima etapa seria fazer a verificação de vestígios de soja transgênica na plantadeira e colheitadeira que poderiam contaminar a soja convencional. Analisar se ainda há plantas transgênicas nas áreas em que se queira plantar a soja convencional também é outro procedimento. Na armazenagem, seria necessário fazer uma boa limpeza nos caminhões, moegas, máquinas de fazer a prélimpeza e silos, além do cuidado com a limpeza dos pés dos elevadores e dos silos. No momento do carregamento da soja, seria necessária uma vistoria nos caminhões transportadores a fim de se certificar que não há nenhum grão transgênico em sua carroceria. Treinamentos com colaboradores a respeito deste procedimento operacional seria fundamental para o sucesso da operação.

\subsubsection{Armazenadores/processadores}

O advento da soja transgênica a partir de 2005 no Brasil (liberação oficial) trouxe consigo algumas mudanças na coordenação da cadeia logística. Um dos atores que sofreram maior impacto foram os armazenadores/processadores, os quais tiveram de lidar, a partir de então, com novos processos relacionados à segregação entre soja geneticamente modificada e convencional, com a realização do recolhimento dos royalties, e com a firmação dos contratos com os produtores rurais para a garantia do recebimento do produto GMO FREE.

Segundo Zilbersztajn, Lazarrini e Machado Filho (1999) e o MAPA (2006), na maior parte dos casos, os armazenadores/processadores estão verticalmente integrados ao 
processo de esmagamento. No entanto, as traders, cooperativas, corretores e armazenadores/processadores, em contato direto com produtores, no processo de aquisição, armazenagem e distribuição de matérias-primas, exercem a função de originadores. As traders transacionam com produtores/cooperativas, de forma a adquirir matéria-prima e efetuar vendas para o mercado externo, podendo atuar também como prestadoras de serviços para indústrias esmagadoras e cooperativas nas suas vendas internacionais.

Nas entrevistas com três armazenadores/processadores que segregavam a soja e pararam de fazê-lo, foi constatado que eles ainda recebem os dois tipos de soja, porém não fazem a segregação dos produtos, ou seja, toda a soja convencional que chega aos armazéns é misturada com a transgênica.

Os armazenadores/processadores avaliam que a contaminação da soja pode ocorrer no transporte, na armazenagem e no transbordo da soja em seus armazéns, além da possibilidade de contaminação no plantio, na colheita e na compra da semente por parte dos produtores. Para eles, a única possibilidade de não haver contaminação seria a segregação total dos ativos (transporte, armazéns, máquinas e equipamentos), ou, em menor grau, por meio de limpeza muito bem realizada ao longo da cadeia.

O teste de transgenia é realizado quando o caminhão chega ao armazém, salvo quando é dito pelo produtor que a soja é transgênica, sendo dispensado o teste, uma vez que os royalties serão recolhidos compulsoriamente. Os kits para os testes de transgenia são fornecidos pela própria Monsanto, e um funcionário do armazém é encarregado de fazer tais testes. Esses armazenadores/processadores fazem apenas o teste da Monsanto (5\% de grãos transgênicos), mas não, o teste SGS da soja GMO FREE (1 grão em 1.000).

Segundo os armazenadores/processadores, a Monsanto faz fiscalizações periódicas para saber se tudo está sendo feito conforme o estabelecido, no que se refere aos testes de transgênica e recolhimento de royalties.

Segundo os armazenadores/processadores, é mais demorado para fazer a checagem dos caminhões carregados com soja convencional, principalmente pelo tempo gasto nos testes de transgenia. Este teste é bancado pelo armazenador/processador, e não é 
repassado para os produtores, salvo se esses quiserem fazer a contra prova do teste, quando acusada a transgenia.

Os armazenadores/processadores também informaram que há maiores dificuldades em estocar os dois tipos de soja nos armazéns, quando optavam por fazer a segregação do produto, aumentando consideravelmente seus custos logísticos, principalmente pelo investimento na construção de um novo armazém exclusivo para o recebimento da soja convencional. A dificuldade aumenta ainda mais pelo fato de terem que gerenciar dois produtos, ficando muitas vezes silos ociosos durante certos períodos do ano. Há também muita dificuldade em movimentar os dois tipos de soja, pelo cuidado que tem que haver para a não contaminação.

Para os armazenadores/processadores, os elevados investimentos em ativos específicos e a dificuldade da gestão dos armazéns inviabilizam a segregação, apesar do pagamento de prêmios pela sua realização. Por isso, eles misturam toda a soja que é trazida para seus armazéns.

A fim de conseguirem a total segregação da soja, todos os armazenadores/processadores informaram ser necessária a criação de uma cadeia logística exclusiva para a soja convencional, separando todos os ativos (transporte, armazenagem, silos, máquinas e equipamentos). Para eles, só assim o risco da contaminação diminuiria para quase zero. Afirmaram ainda que os contratos são fundamentais para que não haja a contaminação, punindo os agentes ao longo da cadeia logística que contaminasse a soja.

Todos os armazenadores/processadores afirmaram já terem feito contratos de entrega de soja livre de transgênicos para algum comprador no mercado internacional, e disseram que pararam de fazer, porque é muito difícil a segregação em seus armazéns, principalmente porque houve um aumento considerável do plantio de soja transgênica no Brasil, fazendo com que se dificulte ainda mais a segregação do produto, pela pouca disponibilidade de soja convencional produzida. Isso faz com que os armazéns que recebem somente a soja livre de transgênicos fiquem ociosos ao longo do ano, e isso não compensaria os investimentos na construção de um armazém especificamente para receber a soja convencional. 
Corroborando com os dados discutidos anteriormente, os armazenadores/processadores ressaltaram que trabalhar com os dois tipos de soja traz problemas de ociosidade nos armazéns, pela falta de regularidade de oferta da soja GMO FREE. Eles relataram, no entanto, que a soja convencional é escoada mais rapidamente do que a soja transgênica, porque a venda para o mercado internacional já é garantida e fechada em contrato, aumentando ainda mais a ociosidade do armazém, o qual é liberado mais rapidamente para a recepção de uma nova carga de soja livre de transgênicos.

Os armazenadores/processadores consideram fundamental a oferta de cursos de capacitação para os funcionários em relação aos cuidados e procedimentos que devem ser realizados para evitar a contaminação no interior do armazém.

$\mathrm{Na}$ opinião deste grupo, o frete pago para a soja convencional deveria ser mais elevado do que a transgênica, pelo fato de exigir dos transportadores um maior cuidado na inspeção e limpeza do caminhão. Porém isso não acontece, o que dificulta ainda mais o processo de segregação.

Dos três armazenadores/processadores entrevistados, dois informaram que os custos com recepção, secagem e armazenagem da soja convencional são maiores do que para a soja transgênica.

Por outro lado, o principal cuidado e procedimento que deveria ser adotado para fazer a segregação da soja, desde a sua chegada até a saída do armazém, seria o seguinte, segundo os armazenadores/processadores: maquinários e equipamentos destinados exclusivamente para manuseio da soja convencional, como secadores, moegas e silos, ou os mesmos, porém passando por um procedimento de limpeza rigoroso.

Os principais resultados obtidos na pesquisa com os armazenadores/processadores que não fazem a segregação são demonstrados na Tabela 4.2. 
Tabela 4.2: Armazenadores/processadores que não fazem a segregação da soja

\begin{tabular}{l|l}
\hline \hline $\begin{array}{l}\text { Dificuldades para } \\
\text { fazer a segregação }\end{array}$ & $\begin{array}{l}\text { 1-É demorado fazer os testes de transgenia; 2-Dificuldade na estocagem das } \\
\text { duas sojas; 3-Custos com a construção de um novo armazém; 4-Dificuldade no } \\
\text { gerenciamento dos armazéns; 5-Ociosidade dos armazéns; 6-Aumento dos } \\
\text { custos de recepção, secagem e armazenagem; 7-Não garantia de recebimento } \\
\text { de prêmios pela segregação do produto. }\end{array}$ \\
\hline $\begin{array}{l}\text { Onde acreditam ter } \\
\text { maior possibilidade de } \\
\text { contaminação }\end{array}$ & $\begin{array}{l}\text { 1-Plantio; 2-Colheita; 3-Transporte; 4-Semente; 5-Armazenagem; } \\
\text { 6-Transbordo. }\end{array}$ \\
\hline $\begin{array}{l}\text { Estratégias para se } \\
\text { fazer a segregação }\end{array}$ & $\begin{array}{l}\text { 1-Maquinários e equipamentos destinados exclusivamente para manuseio da } \\
\text { soja convencional, como secadores, moegas e silos, ou utilizar os mesmos nos } \\
\text { dois processos, porém passando por um procedimento de limpeza rigoroso; 2- } \\
\text { Construção de um novo armazém exclusivo para o recebimento de soja } \\
\text { convencional; 3-Fazer contrato com os produtores para recebimento de soja } \\
\text { GMO FREE; 4-Necessidade de cursos de capacitação para os funcionários. }\end{array}$ \\
\hline \hline
\end{tabular}

Fonte: Elaborado pelo autor (2014)

Os armazenadores/processadores relataram que a segregação trouxe consigo muitas incertezas, e além do seu alto custo, disseram que não há garantia de que haverá mercados dispostos a pagar prêmio pela soja não geneticamente modificada. Porém, parece delineado que haverá mercados interessados em pagar valores adicionais pela soja livre de transgênicos, pelo menos até quando não existam pesquisas que comprovem o mal que a soja transgênica pode trazer para a saúde humana.

Outra constatação interessante a ser ressaltada é que todos os armazéns das regiões visitadas mantêm contratos com a Monsanto para o recolhimento dos royalties referentes ao uso da semente geneticamente modificada. Isso mostra que a coordenação dessa cadeia está se deslocando cada vez mais para arranjos contratuais, o que se deve, possivelmente, à elevação do nível de especificidade dos ativos transacionados, nesse caso a soja convencional, a qual passou a ser um produto diferenciado no mercado, deixando de ser cada vez mais uma commodity para se transformar numa especialidade. 


\section{TEMPOS E CUSTOS LOGÍSTICOS ADICIONAIS PARA A \\ SEGREGAÇÃO DA SOJA CONVENCIONAL E O PAPEL DOS \\ CONTRATOS NA MITIGAÇÃO DOS RISCOS DE \\ CONTAMINAÇÃO}

\subsection{ASPECTOS GERAIS}

Neste capítulo, são apresentadas as informações coletadas na segunda etapa da pesquisa, levantadas através de entrevistas com novos agentes selecionados, conforme apresentado na metodologia do trabalho.

Primeiramente, vale ressaltar que todos os fluxos levantados na primeira etapa da pesquisa (apresentados no Capítulo 4) foram consolidados e devidamente ajustados com as informações levantadas na segunda etapa da pesquisa. Importante frisar ainda que os ajustes necessários já foram feitos nos fluxogramas apresentados no Capítulo 4, para não haver duplicidade da apresentação neste capítulo.

O Capítulo 5 foi estruturado da seguinte forma: 1) aspectos gerais; 2) pontos críticos da cadeia logística da soja (levantados na primeira etapa e consolidados na segunda) e o papel que os contratos assumem como medida mitigadora de riscos de contaminação ao longo da cadeia logística da soja; 3) tempos e custos adicionais necessários para fazer a segregação da soja convencional e prêmios recebidos (levantados em julho de 2014).

\subsection{PONTOS CRÍTICOS E O PAPEL DOS CONTRATOS NA MITIGAÇÃO DOS RISCOS DE CONTAMINAÇÃO}

A Figura 5.1 mostra as etapas logísticas com maior possiblidade de contaminação ao longo da cadeia da soja. Estas etapas merecerão maior atenção em nossa discussão, para que a segregação da soja possa ser feita de forma correta, e para que a cadeia tenha condições de ofertar um produto livre de transgênicos aos mercados que a demandaram. 


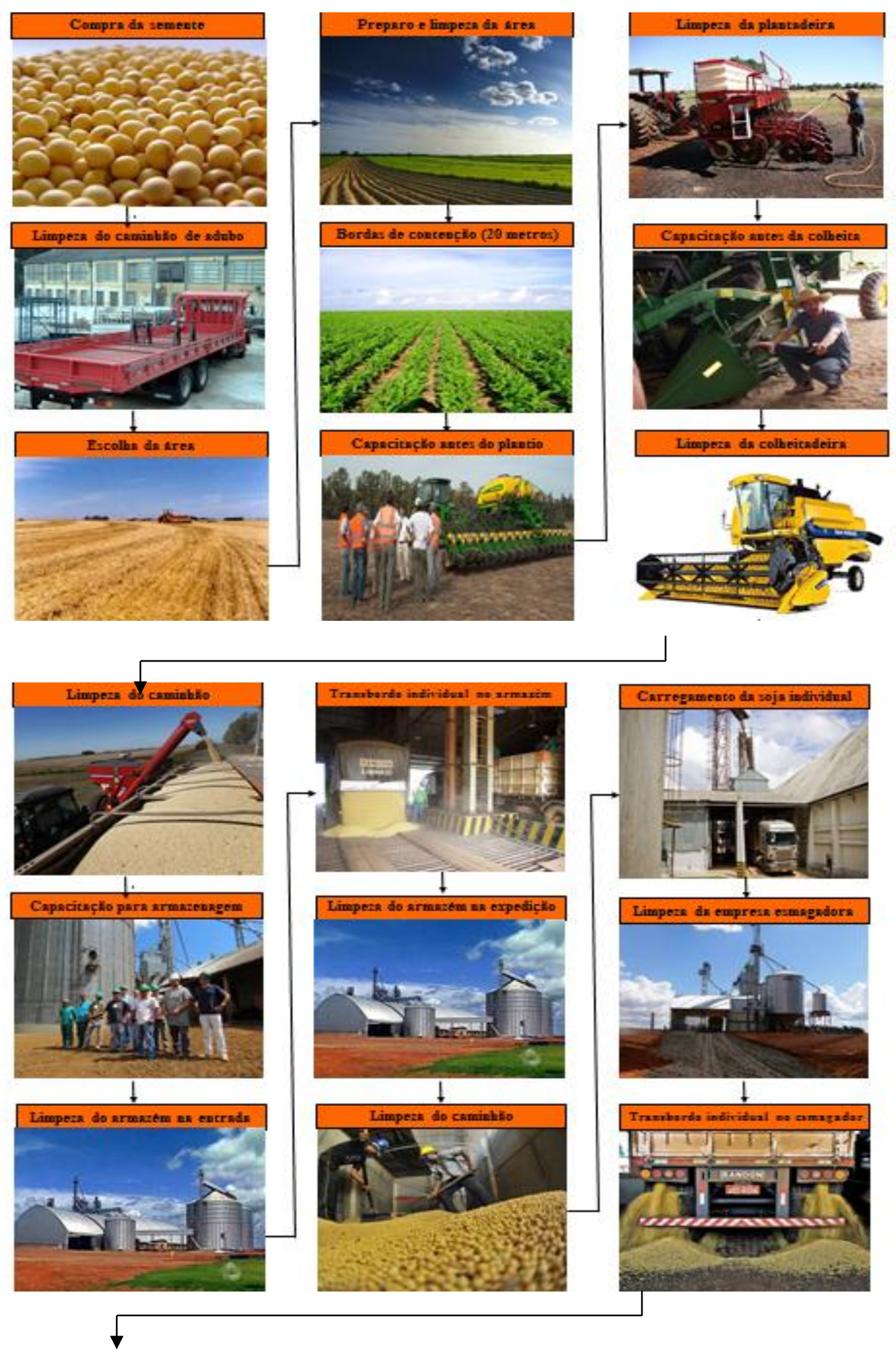




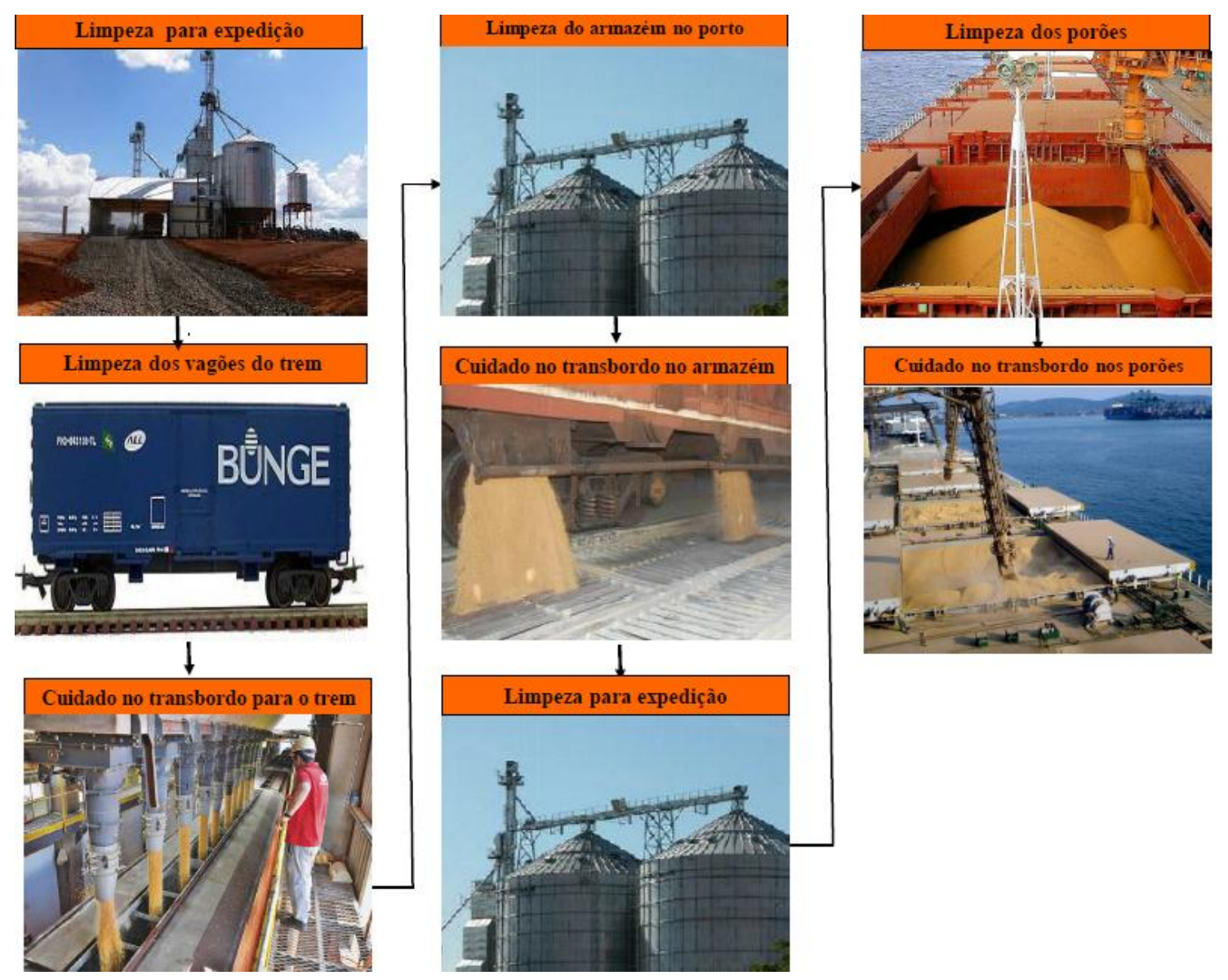

Figura 5.1: Processos logísticos com maiores possibilidades de contaminação na cadeia logística da soja.

Fonte: Elaborado pelo autor (2014)

Para melhor entendimento da importância que os contratos assumem para a melhoria da gestão da cadeia logística da soja, é apresentada a seguir uma correlação destes com os processos apresentados na Figura 5.1, mostrando como podem ajudar a mitigar os riscos de contaminação em cada etapa logística.

1) Compra da semente: para sanar este problema, os agentes entrevistados informaram ser importante que haja contratos responsabilizando a empresa que vende semente contaminada. Todavia, seria necessário fazer testes de transgenia nos sacos das sementes compradas no momento da chegada do produto à fazenda do produtor, aferindo, assim, sua pureza. Se a transgenia for acusada, o fornecedor pode ficar responsável por devolver o dinheiro ou entregar outra semente, ou até mesmo pagar multa. Esse procedimento serve como forte mecanismo de incentivo/controle para que não haja oportunismo por parte da empresa multiplicadora da semente. 
2) Limpeza do caminhão em todos os processos de carga e descarga: segundo os próprios transportadores rodoviários e ferroviários entrevistados, se houvesse contratos os responsabilizando e os remunerando pela limpeza do caminhão, eles prestariam o serviço com maior qualidade. Contudo, estes transportadores argumentaram que os produtores e armazenadores que os contratam não têm interesse em pagar pela prestação desse serviço adicional. No entanto, querem a contrapartida da limpeza do caminhão apenas pelo valor do frete pago. $\mathrm{Na}$ opinião dos entrevistados, se houvesse os contratos da prestação do serviço de limpeza, os riscos de contaminação diminuiriam drasticamente, pois tomariam maior cuidado no momento da higienização de seus caminhões.

Os agentes dessa cadeia informaram também que a única forma de acabar com o problema de contaminação seria ter caminhões e trens exclusivos para fazer o transporte da soja livre de transgênicos, o que elevaria bastante a especificidade dos ativos, e talvez até inviabilizasse sua segregação pelos altos custos em ativos dedicados. Os agentes relataram, no entanto, que se houver uma limpeza minuciosa dos ativos ao longo da cadeia, e se os procedimentos forem realizados com extremo cuidado, o risco da contaminação diminui drasticamente.

3) Escolha da área: é necessário fazer um trabalho de planejamento e controle muito grande para a escolha da melhor área para o plantio, com base em informações históricas da propriedade. Quando a área é do próprio produtor, eles informaram não ser necessário fazer contratos para sanar este problema, a não ser que os próprios produtores queiram terceirizar o processo, contratando uma empresa para prestar o serviço. Quando a área para o plantio é arrendada, os produtores afirmaram ser importante fazer contratos com cláusulas que salvaguardem os produtores de que a área que estão alugando é realmente limpa e propícia para o plantio da soja livre de transgênicos; caso contrário, pode acontecer de os arrendatários dizerem que a área é limpa, e, após a colheita, os locatários perceberem que ela não estava conforme o acordado informalmente, acarretando a contaminação da soja e o não recebimento dos prêmios. 
4) Preparo e limpeza da área: é necessário fazer um trabalho de planejamento e controle muito grande para preparar e limpar a área na qual será plantada a soja livre de transgênicos, pois qualquer semente de soja transgênica remanescente poderá ser germinada e contaminar a soja livre de transgênicos. Segundo informações dos produtores, seria interessante ter alguém contratado especificamente para ficar responsável por esse processo, diminuindo os possíveis problemas de contaminação que possam emergir, de modo a responsabilizar os responsáveis pela contaminação.

5) Bordas de contenção: é necessário fazer um trabalho de planejamento e controle muito grande, de modo a medir corretamente os 20 metros utilizados como bordas de contenção, além de ter cuidado extremo no momento do plantio para não correr o risco de ultrapassar a área que foi isolada. No momento da colheita, deve haver o cuidado para que haja o descarte correto dos 20 metros, de modo a colocá-la no armazém apropriado. Haverá a contaminação, caso esses 20 metros sejam armazenados junto à soja convencional.

6) Capacitação dos funcionários antes do plantio, colheita e armazenagem da soja: é necessário fazer uma capacitação na própria fazenda, mostrando os cuidados que todos os funcionários devem tomar no momento do plantio, colheita e armazenagem da soja, principalmente para os novatos que ainda não tiveram contato com esse processo.

Alguns agentes entrevistados informaram que, dependendo do caso, seria importante pagar uma empresa especializada para fazer um curso de capacitação, mostrando todos os cuidados que devem ser tomados nesses processos tão importantes para a não contaminação da soja. Os entrevistados ressaltaram ainda que deve haver uma conscientização permanente com os empregados da fazenda. O objetivo é dar orientações a todo o momento sobre os cuidados necessários para a não contaminação da soja. Na opinião deles, também seria importante haver alguma forma de contrato para responsabilizar o funcionário que fizesse o processo erroneamente, pois isso colocaria a lavoura em risco de contaminação. 
7) Limpeza das plantadeiras e colheitadeiras: este é um processo que merece atenção especial. Segundo informações dos entrevistados, depois que a limpeza fosse feita, seria necessário que algum especialista fizesse a conferência, para não correr risco de ficar algum vestígio de grão transgênico remanescente nas plantadeiras ou colheitadeiras. Seria também interessante fazer contratos com algum funcionário (especialista), o qual ficaria responsável exclusivamente por este trabalho. Tal prática elevaria a especificidade do ativo humano, pois estaria diretamente relacionada aos investimentos feitos em recursos humanos (qualificação de pessoal). A realização de um processo de aprendizagem contínuo torna o capital humano dotado de habilidades específicas, elevando a especificidade do ativo humano necessário à segregação da soja.

8) Limpeza dos armazéns no momento da entrada e saída de soja convencional: este é um processo que também exige atenção especial, pois qualquer grão transgênico remanescente no armazém antes de sua recepção e expedição poderá causar contaminação. A limpeza deve ser realizada em todos os processos de armazenagem ao longo da cadeia, desde a fazenda do produtor, passando pela indústria esmagadora, até a armazenagem da soja no porto, onde ela ficará aguardando expedição. Os entrevistados disseram que seria necessário ainda haver uma pessoa responsável exclusivamente para controlar a limpeza desses procedimentos, de modo a responsabilizá-la por qualquer erro.

9) Transbordo individual dos caminhões no armazém no momento da carga e descarga da soja: na opinião dos entrevistados, a pessoa responsável pelo controle da limpeza dos armazéns também deveria ser responsável pelo controle de carga e descarga da soja nas moegas. Ele ficaria responsável por não deixar que algum caminhão de soja transgênica seja carregado ou descarregado concomitantemente à soja convencional, já que tal procedimento poderá trazer grandes riscos de contaminação.

10) Limpeza dos contêineres (vagões) dos trens e cuidado no momento do transbordo: assim como na limpeza dos caminhões, seria necessário fazer 
contratos com os operadores ferroviários, responsabilizando-os pela limpeza eficaz dos vagões que transportaram a soja livre de transgênicos até o porto, remunerando-os pelo serviço prestado. Cuidado especial deve ser tomado no momento do transbordo da soja livre de transgênicos para os vagões dos trens, uma vez que o carregamento simultâneo de soja transgênica e convencional poderá acarretar a contaminação.

11) Limpeza dos porões dos navios e cuidado no momento do transbordo: assim como na limpeza dos caminhões e trens, seria necessário fazer contratos com os operadores portuários, responsabilizando-os pela limpeza eficaz dos porões que transportarão a soja livre de transgênicos até o mercado internacional, remunerando-os pelo serviço prestado. Cuidado especial deve ser tomado no momento do transbordo da soja livre de transgênicos para os porões dos navios, pois o carregamento simultâneo das sojas poderá acarretar na contaminação.

\subsubsection{Estratégias e Parcerias Logísticas: o Papel dos Contratos como Mecanismos de Incentivo/Controle para o Recebimento dos Prêmios pela Segregação da Soja}

Para melhor entender o processo logístico da cadeia da soja, é importante analisar o processo de recebimento de prêmios da soja livre de transgênicos. As entrevistas realizadas com os armazenadores/processadores que fazem a segregação da soja na primeira e segunda etapas desta pesquisa nos permitiram lançar um olhar sistêmico sobre esses assuntos.

Foi identificado que os armazenadores/processadores que fazem a segregação pagam prêmios tanto aos produtores que conseguem entregar a soja livre de transgênicos quanto aos operadores portuários. A tolerância de transgênicos para o pagamento dos prêmios é de 1 grão em 1.000 , ou seja, se no teste de transgenia for encontrado um grão de soja transgênica em mil grãos de soja convencional, a empresa não paga o prêmio para o produtor, recusando-se a carregar a soja na fazenda, e executando o contrato, com $20 \%$ de multa. Mais adiante será tratado o assunto relacionado às cláusulas contratuais acordadas entre as partes para entrega da soja livre de transgênicos e o recebimento dos prêmios. 
Os produtores recebem o prêmio quando conseguem fazer a segregação da soja em suas fazendas, entregando-a para a empresa armazenadora/processadora que também faz a segregação da soja. Caso esses produtores resolvam entregar a soja livre de transgênicos para algum armazém que não faz a segregação, possivelmente não receberá o prêmio, pois estes armazenadores/processadores não têm interesse em fazer a segregação.

Há dados na literatura que mostram a diferença dos custos de produção entre soja transgênica e convencional, porém, para melhor entender como a decisão do produtor é tomada (em termos econômicos e financeiros) foram levadas em consideração as informações do entrevistado, que foi coletada em abril de 2014. Segundo ele, a soja transgênica tem um custo $\mathrm{R} \$ 1.350,00$ por hectare; a convencional, $\mathrm{R} \$ 1.550,00$. A fim de que se chegue ao valor compensatório, é necessário, portanto, fazer a seguinte conta: divide-se esse valor por 50 sacas produzidas (média da produtividade por hectare). A soja RR vai custar R \$27,00 por saca por hectare, enquanto a convencional custará $\mathrm{R} \$$ 31,00 .

O que é compensador para o produtor é justamente o valor do prêmio recebido, uma vez que o preço da soja convencional recebida é de $17 \%$ superior por saca. Sendo assim, o preço da saca da soja transgênica chega a $R \$ 60,00$, já a convencional vale $R \$ 70,20$ (dados coletados em abril de 2014).

Para tanto, a soja convencional irá gerar uma receita bruta por hectare de $\mathrm{R} \$ 3.510,00$ ( $\mathrm{R} \$ 70,20 \times 50)$. A transgênica, por sua vez, uma receita bruta por hectare de $\mathrm{R} \$$ $3.000,00$ ( $\mathrm{R} \$ 60,00$ x 50). Para se chegar ao valor final recebido de soja GMO FREE, basta fazer a diluição de todos os custos, sendo para a soja convencional o seguinte: $R$ \$ $3.510,00-\mathrm{R} \$ 1.550,00=\mathrm{R} \$ 1.960,00$; na transgênica: $\mathrm{R} \$ 3.000,00-\mathrm{R} \$ 1.350,00=$ $\mathrm{R} \$ 1.650,00$.

A diferença de receita líquida da convencional para a transgênica é de $\mathrm{R} \$ 310,00$ (R\$ $1.960,00-\mathrm{R} \$ 1.650,00)$ a mais por hectare, o que em termos percentuais representa $8,42 \%$ a mais para a soja convencional.

Essas informações são apresentadas detalhadamente na Tabela 5.1. 
Tabela 5.1: Custos de produção e prêmio recebido pelos produtores

\begin{tabular}{|c|c|c|}
\hline Custos de produção e prêmio recebido & Soja Transgênica & Soja Convencional \\
\hline Custo de produção por hectare & $\mathrm{R} \$ 1.350,00$ & $\mathrm{R} \$ 1.550,00$ \\
\hline Produtividade média por hectare & 50 sacas & 50 sacas \\
\hline Custo médio por hectare & $\mathrm{R} \$ 27,00$ & $\mathrm{R} \$ 31,00$ \\
\hline Preço de venda & $\mathrm{R} \$ 60,00$ & $\mathrm{R} \$ 70,20$ \\
\hline Receita bruta por hectare & $\mathrm{R} \$ 3.000,00$ & $\mathrm{R} \$ 3.510,00$ \\
\hline Receita líquida por hectare & $\begin{array}{c}\mathrm{R} \$ 3.000,00-\mathrm{R} \$ \\
1.350,00=\mathrm{R} \$ 1.650,00\end{array}$ & $\begin{array}{c}\mathrm{R} \$ 3.510,00-\mathrm{R} \$ \\
1.550,00=\mathrm{R} \$ 1.960,00\end{array}$ \\
\hline $\begin{array}{l}\text { Valor adicional recebido em } \mathrm{R} \$ / \text { hectare pela } \\
\text { segregação }\end{array}$ & \multicolumn{2}{|c|}{$\begin{array}{c}\mathrm{R} \$ 310,00 \text { ou } 8.42 \% \text { a mais para a soja } \\
\text { convencional }\end{array}$} \\
\hline
\end{tabular}

Fonte: Dados da pesquisa (2014)

Essa seria a taxa recebida pela segregação. Para recebê-la, os produtores devem assumir todos os riscos da contaminação, desde o momento da compra da semente até a saída da soja de sua fazenda, tendo que arcar com os custos relacionados aos cuidados e procedimentos que devem ser tomados para que não haja o contágio. Além disso, para os produtores receberem esse valor adicional, devem fazer investimentos em ativos específicos para conseguir fazer a separação das sojas.

Todos os produtores entrevistados na primeira e segunda etapas da pesquisa que atualmente fazem a segregação informaram que irão continuar trabalhando com a segregação, a fim de oferecerem a soja livre de transgênicos se o valor do prêmio continuar. Caso contrário, migrarão para a produção de soja transgênica.

Sendo assim, o valor agregado da especialidade estaria compensando os elevados custos da segregação, pagos pelos prêmios.

Um atributo trabalhado na NEI/ECT diz respeito à incerteza. Essa característica da transação está evidente quando é analisado o pagamento do prêmio ao produtor, uma vez que não se sabe se haverá continuidade desse pagamento no futuro, muito menos o valor que o prêmio terá, sendo totalmente dependente do interesse do mercado internacional em continuar pagando a diferença do preço pela soja livre de transgênicos. Porém, há pesquisas demonstrando que haverá a continuidade, ou até mesmo o aumento da demanda pela soja livre de transgênicos no mundo, o que diminuiria as incertezas relativas a essa transação. 
Os resultados financeiros mostrados anteriormente dão uma indicação positiva da viabilidade de produzir a soja convencional em detrimento da transgênica. Porém, muitos produtores não o fazem pelas incertezas do recebimento do valor do prêmio nem pelo alto investimento em ativos específicos para a segregação. Segundo informações dos produtores entrevistados, todos os investimentos feitos na segregação podem ser perdidos caso não haja o pagamento de prêmio no futuro, ou caso haja a contaminação em alguma etapa da cadeia. Sendo assim, os contratos serviriam de mecanismos de incentivo/controle para que os produtores pudessem se salvaguardar dessas incertezas e ter incentivos para o investimento.

\subsubsection{O Papel dos Armazenadores/processadores como Coordenador de Contratos na Cadeia Logística da Soja}

A teoria dos contratos tem demonstrado importância considerável na análise logística das cadeias produtivas para o melhor entendimento de como eles podem servir de incentivo/controle para a segregação, emblematicamente na cadeia logística da soja. Esta cadeia passou a conviver com atributos de qualidade que devem ser monitorados, via contratos formais, a fim de se conseguir um produto com total pureza para a entrega no mercado internacional.

Conseguiu-se ter acesso a um contrato que é feito entre produtor e empresa compradora da soja (fornecido por um dos produtores entrevistados). Isso ajudou a entender melhor como os contratos são importantes na cadeia da soja, servindo de mecanismos de incentivo/controle para que não haja sua contaminação ao longo da cadeia logística.

Importante ressaltar que a empresa compradora (SELECTA) já fecha contrato de venda da soja livre de transgênicos para o mercado internacional antes de fechar contratos com os produtores. Feito o contrato no mercado internacional, a empresa tem motivação para buscar no mercado doméstico produtores que conseguem fazer a segregação da soja para a entrega do produto livre de transgênicos. Encontrando os produtores que conseguem fazer a segregação da soja, a empresa fecha contratos, acordando o valor do preço pela soja livre de transgênicos. 
A seguir são apresentadas as cláusulas contratuais, as quais ajudam a entender melhor como se dá todo o processo contratual entre as partes. O contrato não foi referenciado para preservar o produtor que pediu sigilo nas informações apresentadas.

O Parágrafo $5^{\circ}$ do contrato versa sobre o recolhimento dos royalties, e diz:

... a COMPRADORA descontará, ainda, Direitos de Propriedade Intelectual (DPI) devidos à MONSANTO DO BRASIL LTDA, com sede em São Paulo (SP), inscrita no CNPJ no64.858.525/0001-45, pela utilização da tecnologia "Round up Ready", declarada pelo VENDEDOR ou condicionada ao resultado dos testes de transgenia a serem aplicados a cada carga recebida. Para cargas que tiverem resultado positivo (a soja contém o "gene Round up Ready"), os valores acima (DPI) será retido em definitivo a favor da MONSANTO, atualmente em $2 \%$ aplicada sobre o valor da mercadoria testada. Para as cargas que tiverem resultado negativo (a soja não contém o "gene Round up Ready"), a autorização condicional das retenções acima não gerará nenhum débito ao VENDEDOR. Quando o VENDEDOR "não declarar a transgenia" da mercadoria vendida, o mesmo autoriza expressamente a COMPRADORA a reter o valor a título de DPI pela alíquota máxima, atualmente em 3\% (três por cento), aplicada sobre o valor da mercadoria testada e com resultado positivo (mercadoria transgênica). É de responsabilidade exclusiva do VENDEDOR, ainda, comunicar à COMPRADORA a existência de "créditos de isenção" junto à MONSANTO, para que a mesma, no ato da fixação do preço definitivo, possa consultar e efetuar o crédito do valor correspondente. Não se aplicará a presente retenção na hipótese do VENDEDOR ter aderido ao sistema de DPI da MONSANTO na qualidade de PARTICIPANTE, o que deve ser comprovado pelo VENDEDOR no ato da celebração do presente contrato.

Outra cláusula importante de ser destacada neste contrato diz respeito à qualidade do produto. Cláusula Quarta: DA QUALIDADE DO PRODUTO, o parágrafo $6^{\circ}$ diz o seguinte:

Para as compras de soja GMO FREE, a COMPRADORA utiliza testes de sensibilidade, esses testes têm por finalidade, quantificar a sensibilidade de percentual de transgenia em cada percentual de soja aferido, sendo que, terá por limite o percentual de $0,10 \%$ (zero vírgula dez por cento), para cada medida de 1 (um) grão para 1.000 (um mil) grãos de amostra que indicam a presença ou ausência de transgênico, ou seja, de OGMs (Organismos Geneticamente Modificados) em grãos de soja, para efeito da segregação da soja transgênica e não transgênica. Se for detectada transgenia (Organismo Geneticamente Modificado) nos testes realizados na origem do carregamento, a COMPRADORA se reserva o direito de rescindir imediatamente o presente instrumento contratual, não sendo devida pela COMPRADORA nenhum valor, a qualquer título que seja ao (à) VENDEDOR (A).

A Cláusula quinta do contrato que versa sobre as DISPOSIÇÕES GERAIS diz o seguinte: 
O VENDEDOR, de igual modo tem ciência de que a venda ajustada, para entrega futura, insere-se em uma sucessão de transmissões, para o mercado interno/e ou externo e/ou industrialização, a critério da COMPRADORA, as quais se realizam antes mesmo de se efetuar o fato real da entrega da mercadoria vendida, de maneira que a falta do cumprimento do contrato pelo VENDEDOR produzirá sérios danos à COMPRADORA, pelos reflexos provocados nos negócios sucessivos, relativos à mercadoria adquirida ou aos seus derivados.

Caso o COMPRADOR ou VENDEDOR não cumpra com quaisquer das obrigações ora avençadas, ficará sujeito, independentemente da interpelação ou protesto, ao pagamento de cláusula penal, no valor de $20 \%$ (vinte por cento) do valor total da compra e venda ou da quantidade de grãos não entregue, em caso de inadimplemento parcial, sem prejuízo da execução do contrato, das perdas e danos e mais consequências do seu não cumprimento.

Observou-se que os contratos têm papel fundamental na gestão da cadeia logística da soja, servindo como mecanismos de incentivo/controle norteador de todas as estratégias de segregação dos agentes ao longo da cadeia. Tais mecanismos são motivados pela necessidade de se garantir um produto livre de transgênicos, de modo a assegurar a pureza do produto e o recebimento do prêmio.

Na opinião das empresas armazenadoras/processadoras entrevistadas, todos os portos do Brasil têm condições de fazer a segregação da soja, mas a maior limitação é a falta de espaço suficiente para fazer este fim.

Para resolver esse problema, uma das empresas armazenadoras/processadoras entrevistadas informou fazer contratos com um armazém próximo ao porto de Tubarão (terminal graneleiro do Porto de Vitória - ES), para o armazenamento da soja antes de ser embarcada para o mercado internacional. Fazendo isso, eles garantem a segregação do produto e minimizam a possibilidade de haver a mistura em algum armazém público. Quando a soja chega ao armazém, é feito novamente o teste de transgenia para garantir que não houve contaminação no trajeto do armazém de Araguari-MG para o armazém de Tubarão-ES.

Por outro lado, a empresa não fornece sementes de soja convencional para os produtores. No entanto, elas estão iniciando parcerias com Multinacionais que possuem projetos com sementes convencionais, fechando contratos com aqueles que têm maior capacidade gerencial e infraestrutural de fazer a segregação do produto. 
Essa empresa relatou também que existem contratos em todo o ponto de embarque/desembarque para fazer os testes de transgenia. Além disso, sempre que a soja GMO FREE vai ser carregada/descarregada, a empresa envia um técnico que acompanha todo o procedimento, para garantir a limpeza dos veículos e a inspeção da qualidade do produto.

Todas as empresas armazenadoras/processadoras também informaram manter contratos com a empresa detentora da patente da soja transgênica (MONSANTO), de modo a prestar o serviço de recolhimento de royalties.

Essa discussão vai ao encontro do que Wilkinson e Pessanha já relatavam em 2005, mostrando que tal problema foi observado na fase inicial de expansão da soja transgênica nos EUA, onde, inicialmente, foi questionada a inviabilidade dos custos de segregação de grãos geneticamente modificados e livres de transgênicos. Hoje, naquele país, vem se disseminando a prática da segregação a partir da promoção dos novos mercados representados pelas especialidades (WILKINSON; PESSANHA, 2005).

O papel dos armazenadores/processadores na coordenação das atividades da cadeia logística da soja pode ser destacado como um dos fatores que evidenciam a competitividade brasileira nas exportações do complexo da soja. Essa coordenação envolve um complexo e integrado mecanismo de financiamento, processamento e escoamento da produção, mobilizando os principais agentes da cadeia por meio de uma diversidade de formas contratuais, as quais tendem a se tornar mais complexas a partir do advento da soja geneticamente modificada e, principalmente, com a estruturação dos novos mercados de especialidades (soja livre de transgênicos). Em qualquer caso, podese assegurar que a manutenção e/ou ampliação da competitividade do SAG da soja requer cada vez mais uma maior integração entre os seus elos, propiciando uma coordenação mais eficiente, tanto em termos de sua dimensão técnica quanto econômica.

A indústria de esmagamento, refino e derivados da soja apresenta padrões de organização e conduta bastante heterogêneos, com níveis diferenciados de integração vertical e de diversificação para outros negócios (MAPA, 2006). 
Isso também foi constatado no estudo da presente tese. Do ponto de vista das transformações organizacionais ocorridas na cadeia logística da soja, tanto em nível das regiões estudadas, quanto em nível nacional, destaca-se o modo de coordenação das transações praticado por essas empresas, o qual se afasta cada vez mais das formas típicas de mercado, aproximando-se de formas híbridas, em que as relações contratuais, nas mais diversas modalidades, vêm prevalecendo. Isso pode ser constatado através dos contratos realizados pelos armazenadores/processadores ao longo de toda cadeia, pois, através destes, a empresa consegue êxito na segregação e na entrega de um produto diferenciado aos mercados que a demandarem.

A análise da realidade em torno dos agentes da cadeia logística da soja corrobora com a ideia de que a eliminação dos gargalos, os quais conformam os direcionadores da competitividade, depende mais de ações coordenadas entre os elos envolvidos (via contratos) do que de decisões "intrafirma" no sentido neoclássico.

Nesse sentido, podem ser destacados os principais elementos do entorno dos armazenadores/processadores com os outros elos dessa cadeia, os quais são reforçados pela tendência de evolução da transação por meio do mercado para a contratual. A saber:

a) A reconhecida fragilidade na gestão do negócio agrícola por parte do produtor rural eleva o nível de incerteza na transação, em decorrência dos riscos de produção e de preços (principalmente o da soja livre de transgênicos). Isso contribui para a evolução rumo a formas de governança contratuais mais estreitas com os armazenadores/processadores.

b) A conhecida deficiência na infraestrutura logística para o escoamento dos produtos do complexo de soja (apresentadas no Capítulo 3) traduz-se não apenas na elevação de custos associados ao transporte e armazenagem, mas constitui-se também num incentivo para novas modalidades de integração (governança contratual) entre os segmentos da cadeia, notadamente entre os armazenadores/processadores, produtores rurais $\mathrm{e}$ operadores portuários, com vistas à otimização dos processos logísticos. 
Importante frisar que os armazenadores/processadores também assumem o risco da segregação com os outros elos da cadeia (transportadores rodoviários e ferroviários), os quais não mantêm vínculo contratual formal. Isso possivelmente aumenta os custos de monitoramento por não ter um mecanismo formal de incentivo/punição para que os armazenadores/processadores façam valer seus interesses no que tange à limpeza dos caminhões e trens envolvidos no transporte da soja livre de transgênicos.

Todas estas informações corroboram com o que Medeiros et. al. (2009) já apontavam, quando diziam que o elo dos armazenadores/processadores têm razões que direcionam para a tendência de concentração e diversificação, e é estruturalmente caracterizado por uma tendência à integração vertical, incorporando as etapas de esmagamento, processamento, refino do óleo de soja e produção de derivados. Nesse sentido, as empresas desse segmento, naturalmente, estariam vocacionadas para a ampliação dos seus limites no sentido coaseano ${ }^{19}$.

\subsection{TEMPOS E CUSTOS ADICIONAIS PARA FAZER A SEGREGAÇÃO DA SOJA CONVENCIONAL}

Os tempos e custos adicionais levantados na segunda etapa da pesquisa mostram o quanto é dispendioso fazer a segregação da soja convencional ao longo da cadeia logística. Além dos levantamentos sobre tempos e custos adicionais (apresentados nas tabelas a seguir), também foi identificado o valor do prêmio recebido por cada agente para fazer a segregação da soja em sua etapa logística.

As tabelas apresentadas neste capítulo foram configuradas da seguinte forma.

1) Primeira coluna: são mostrados os processos logísticos apontados como distintos para a soja transgênica e convencional (processos adicionais para a segregação da soja), os quais necessitam de maiores cuidados, e apontados como riscos de contaminação caso não o façam; 2) Segunda coluna: tempo gasto para fazer realizar cada processo; 3) Terceira coluna: custo adicional de cada processo, conseguido através da média aritmética simples das respostas fornecidas por cada elo entrevistado; 4) Quarta coluna:

\footnotetext{
${ }^{19}$ Coaseano - no sentido de em conformidade com a teoria proposta por Ronald Coase em COASE, R. H.The Nature of the Firm. Economicano 4. November. 1937.
} 
os custos adicionais por saca de soja em valor percentual por cada processo realizado. Também conseguido através da média aritmética simples das respostas fornecidas por cada elo entrevistado.

A Tabela 5.2 mostra os tempos e custos adicionais encontrados nos processos que dizem respeito aos produtores dentro da cadeia logística da soja. Os dados apresentados foram extraídos de entrevistas com 10 produtores na segunda etapa da pesquisa, conforme definido na metodologia do trabalho.

Importante ressaltar que os valores informados nas próximas tabelas foram extraídos conforme definido na metodologia do trabalho, ou seja, utilizou-se a média aritmética simples das entrevistas realizadas com os agentes de cada elo logístico para se chegar aos resultados finais. Por exemplo: para encontrar o valor do Tempo Gasto no primeiro processo citado na Tabela 5.2, foi somado o tempo informado por cada produtor (10 produtores no total) e, posteriormente, dividido por 10, para se chegar ao valor da média aritmética simples. A mesma lógica de cálculo foi utilizada para o Custo Adicional (R\$) e para o Custo Adicional por Saca (\%). Todas as informações citadas nas tabelas a seguir foram extraídas de informações coletadas em pesquisa de campo realizada em julho de 2014. 
Tabela 5.2: Tempos e custos adicionais para os produtores fazerem a segregação da soja

\begin{tabular}{|c|c|c|c|}
\hline Processos logísticos & Tempo Gasto & $\begin{array}{c}\text { Custo Adicional } \\
\text { (R\$) }\end{array}$ & $\begin{array}{c}\text { Custo } \\
\text { Adicional por } \\
\text { Saca }(\%) \\
\end{array}$ \\
\hline $\begin{array}{l}\text { Limpeza dos caminhões que transportam a } \\
\text { soja livre de transgênicos da lavoura até o } \\
\text { armazém na fazenda }\end{array}$ & $\begin{array}{l}30 \text { min por } \\
\text { caminhão }\end{array}$ & $\begin{array}{l}\mathrm{R} \$ 20,00 \text { por } \\
\text { caminhão }\end{array}$ & 0,01 \\
\hline $\begin{array}{l}\text { Planejamento e programação para procurar } \\
\text { e adquirir semente de soja livre de } \\
\text { transgênicos confiável }\end{array}$ & 6 meses ao ano & $\mathrm{R} \$ 3.000,00$ & 0,08 \\
\hline $\begin{array}{l}\text { Limpeza do espaço que recebe insumos da } \\
\text { soja livre de transgênicos, bem como seu } \\
\text { planejamento e o controle para que não } \\
\text { haja riscos de contaminação, } \\
\text { principalmente no local destinado à } \\
\text { armazenagem do adubo }\end{array}$ & 6 meses ao ano & $\mathrm{R} \$ 3.000,00$ & 0,08 \\
\hline $\begin{array}{l}\text { Controle e fiscalização da área que será } \\
\text { plantada a soja livre de transgênicos para } \\
\text { evitar a germinação de qualquer planta de } \\
\text { soja transgênica junto da convencional }\end{array}$ & 2 dias ao ano & $\mathrm{R} \$ 100,00$ & 0,01 \\
\hline $\begin{array}{l}\text { Planejamento e preparação do plantio da } \\
\text { soja livre de transgênicos }\end{array}$ & 7 dias ao ano & $\begin{array}{l}\mathrm{R} \$ 15,00 \text { por } \\
\text { hectare }\end{array}$ & 0,5 \\
\hline $\begin{array}{l}\text { Limpeza das plantadeiras antes do plantio } \\
\text { da soja livre de transgênicos }\end{array}$ & $\begin{array}{l}2 \text { horas por } \\
\text { plantadeira }\end{array}$ & $\begin{array}{l}\mathrm{R} \$ 25,00 \text { por } \\
\text { plantadeira }\end{array}$ & 0,01 \\
\hline $\begin{array}{l}\text { Capacitação, monitoramento e } \\
\text { conscientização dos empregados, } \\
\text { mostrando os cuidados e procedimentos } \\
\text { necessários ao plantio, colheita, } \\
\text { armazenagem e expedição da soja livre de } \\
\text { transgênicos }\end{array}$ & $\begin{array}{c}3 \text { horas por dia. } 365 \\
\text { dias por ano. }\end{array}$ & $\mathrm{R} \$ 14.000,00$ & 1,3 \\
\hline $\begin{array}{l}\text { Aplicações adicionais de defensivos na } \\
\text { soja livre de transgênicos. Duas aplicações } \\
\text { adicionais }\end{array}$ & 4 dias ao ano & $\begin{array}{l}\mathrm{R} \$ 30,00 \text { por } \\
\text { hectare }\end{array}$ & 1,2 \\
\hline $\begin{array}{l}\text { Limpeza das colheitadeiras antes da soja } \\
\text { livre de transgênicos ser colhida }\end{array}$ & $\begin{array}{l}3 \text { horas por } \\
\text { colheitadeira }\end{array}$ & $\begin{array}{l}\mathrm{R} \$ 37,50 \text { por } \\
\text { colheitadeira }\end{array}$ & 0,02 \\
\hline $\begin{array}{l}\text { Teste de transgenia (SGS) antes da entrada } \\
\text { da soja nos armazéns da fazenda }\end{array}$ & $\begin{array}{l}15 \text { min para cada } \\
\text { teste }\end{array}$ & $\begin{array}{l}\mathrm{R} \$ 60,00 \text { por } \\
\text { teste }\end{array}$ & 0,03 \\
\hline $\begin{array}{l}\text { Limpeza das moegas, elevadores, } \\
\text { secadores e caixa de expedição para poder } \\
\text { fazer o carregamento/descarregamento dos } \\
\text { caminhões nos armazéns }\end{array}$ & 4 dias ao ano & $\mathrm{R} \$ 800,00$ & 0,02 \\
\hline $\begin{array}{l}\text { Tempo de espera para o } \\
\text { carregamento/descarregamento dos } \\
\text { caminhões que transportam soja livre de } \\
\text { transgênicos }\end{array}$ & $\begin{array}{l}20 \text { min por } \\
\text { caminhão }\end{array}$ & $\begin{array}{l}\mathrm{R} \$ 10,00 \text { por } \\
\text { caminhão }\end{array}$ & 0,01 \\
\hline $\begin{array}{l}\text { Teste de transgenia (SGS) antes do } \\
\text { carregamento da soja no caminhão que } \\
\text { transporta a soja até o } \\
\text { armazenador/processador (esmagadora) }\end{array}$ & $\begin{array}{c}15 \text { min para cada } \\
\text { teste }\end{array}$ & $\begin{array}{c}\mathrm{R} \$ 60,00 \text { por } \\
\text { teste }\end{array}$ & 0,03 \\
\hline $\begin{array}{l}\text { Descarte da soja contaminada nas bordas } \\
\text { de contenção, caminhões, plantadeiras, } \\
\text { colheitadeiras, lonas, armazéns, máquinas } \\
\text { e equipamentos em geral }\end{array}$ & $\begin{array}{c}20 \text { min para cada } \\
\text { descarte }\end{array}$ & $\begin{array}{c}\mathrm{R} \$ 0,60 \text { por saca } \\
\text { de soja } \\
\text { descartada }\end{array}$ & 1 \\
\hline \multicolumn{3}{|c|}{ Custo Total da Segregação } & $4,3 \%$ \\
\hline
\end{tabular}

Fonte: Dados da pesquisa (2014) 
Os dados apresentados no Capítulo 5.2.1 mostram que o valor do prêmio recebido pelos produtores é de $8,42 \%$ a mais por cada saca. O custo da segregação, conforme apresentado na Tabela 5.2, é de 4,3\% por saca de soja segregada. Ou seja, o produtor está recebendo um prêmio real de $4,12 \%$ a mais por cada saca de soja segregada.

A Tabela 5.3 mostra os tempos e custos adicionais encontrados nos processos que dizem respeito aos armazenadores/processadores dentro da cadeia logística da soja. Os dados apresentados foram extraídos de entrevistas com 5 armazenadores/processadores na segunda etapa da pesquisa, conforme definido na metodologia do trabalho.

\section{Tabela 5.3: Tempos e custos adicionais para os armazenadores/processadores fazerem a segregação da soja}

\begin{tabular}{|c|c|c|c|}
\hline Processos logísticos & Tempo Gasto & $\begin{array}{c}\text { Custo Adicional } \\
\text { (R\$) }\end{array}$ & $\begin{array}{c}\text { Custo } \\
\text { Adicional por } \\
\text { Saca }(\%)\end{array}$ \\
\hline $\begin{array}{l}\text { Levantamento da proporção da área de } \\
\text { soja convencional que está sendo plantada } \\
\text { em sua região para fazer o planejamento } \\
\text { da armazenagem para a próxima safra }\end{array}$ & 15 dias ao ano & $\mathrm{R} \$ 6.000,00$ & 0,02 \\
\hline $\begin{array}{l}\text { Teste de transgenia (SGS) na chegada do } \\
\text { caminhão ao armazenador/processador }\end{array}$ & $\begin{array}{l}15 \text { min para cada } \\
\text { teste }\end{array}$ & $\begin{array}{l}\mathrm{R} \$ 60,00 \text { por } \\
\text { teste }\end{array}$ & 0,03 \\
\hline $\begin{array}{l}\text { Planejamento e controle do } \\
\text { descarregamento dos caminhões no } \\
\text { processo de entrada da soja nos armazéns, } \\
\text { esperando que seja feito primeiramente o } \\
\text { transbordo daqueles que irão fazer o } \\
\text { transbordo da soja transgênica para não } \\
\text { correr o risco de contaminação }\end{array}$ & $\begin{array}{l}40 \text { min por } \\
\text { caminhão }\end{array}$ & $\begin{array}{l}\mathrm{R} \$ 66,00 \text { por } \\
\text { caminhão }\end{array}$ & 0,03 \\
\hline $\begin{array}{l}\text { Capacitação dos empregados, orientando- } \\
\text { os dos possíveis problemas de } \\
\text { contaminação em todas as etapas logísticas } \\
\text { do armazém }\end{array}$ & 2 dias ao ano & $\mathrm{R} \$ 7.000,00$ & 0,02 \\
\hline $\begin{array}{l}\text { Monitoramento e controle de todas as } \\
\text { etapas da linha de produção para a } \\
\text { armazenagem da soja livre de transgênicos }\end{array}$ & 365 dias ao ano & $\mathrm{R} \$ 150.000,00$ & 1,02 \\
\hline $\begin{array}{l}\text { Limpeza no pátio, máquinas e } \\
\text { equipamentos do armazém antes da } \\
\text { recepção e expedição da soja livre de } \\
\text { transgênicos }\end{array}$ & 20 dias ao ano & $\mathrm{R} \$ 7.920,00$ & 0,02 \\
\hline $\begin{array}{l}\text { Planejamento e controle do carregamento } \\
\text { dos caminhões no processo de expedição, } \\
\text { esperando que seja feito primeiramente o } \\
\text { carregamento daqueles que irão } \\
\text { transportar soja transgênica para não } \\
\text { correr o risco de contaminação }\end{array}$ & $\begin{array}{l}40 \text { min por } \\
\text { caminhão }\end{array}$ & $\begin{array}{l}\mathrm{R} \$ 66,00 \text { por } \\
\text { caminhão }\end{array}$ & 0,03 \\
\hline $\begin{array}{l}\text { Teste de transgenia (SGS) antes do } \\
\text { carregamento do caminhão ou trem para o } \\
\text { porto de destino }\end{array}$ & $\begin{array}{c}15 \text { min para cada } \\
\text { teste }\end{array}$ & $\begin{array}{c}\mathrm{R} \$ 60,00 \text { por } \\
\text { teste }\end{array}$ & 0,03 \\
\hline \multicolumn{3}{|c|}{ Custo Total da Segregação } & $1,2 \%$ \\
\hline
\end{tabular}

Fonte: Dados da pesquisa (2014) 
Os armazenadores/processadores afirmaram receber, em média, $\mathrm{R} \$ 8,00$ a mais por saca de soja livre de transgênicos. De acordo com suas informações, este valor é fechado antecipadamente através de contratos com o mercado internacional, e este é o valor recebido pela segregação feita ao longo da cadeia. Ou seja, pagam $\mathrm{R} \$ 70,20$ para o produtor que entrega soja livre de transgênicos em seu armazém e recebem $\mathrm{R} \$ 78,20$.

Dividindo esse valor de $\mathrm{R} \$ 8,00$ a mais por cada saca segregada, pelo valor pago aos produtores por saca, que é de $\mathrm{R} \$ 70,20$, pode ser constatado que os armazenadores/processadores estão recebendo em média $11,4 \%$ de prêmio pela segregação da soja. O custo da segregação, conforme apresentado na Tabela 5.3, é de $1,2 \%$ para cada saca de soja segregada.

Os armazenadores/processadores informaram também que gerenciam todos os contratos da cadeia relacionados à segregação da soja. Importante ressaltar que o pagamento do prêmio é feito somente para os produtores rurais e operadores portuários, e o valor do prêmio real recebido pelo armazenador é deduzido do valor despendido pela sua segregação $(1,2 \%)$, mais o valor pago aos operados portuários $(1 \%)$, que dará um valor real de $9,2 \%$ pela segregação e gestão dos contratos ao longo da cadeia.

A Tabela 5.4 mostra os tempos e custos adicionais encontrados nos processos que dizem respeito aos transportadores rodoviários dentro da cadeia logística da soja. Os dados apresentados foram extraídos de entrevistas com 10 transportadores rodoviários na segunda etapa da pesquisa, conforme definido na metodologia do trabalho. Os dados apresentados mostram as atividades logísticas desempenhadas pelo transportador rodoviário desde o transporte de insumos para a fazenda do produtor até o transbordo da soja no porto. 


\section{Tabela 5.4: Tempos e custos adicionais para os transportadores rodoviários fazerem a segregação da soja}

\begin{tabular}{|c|c|c|c|}
\hline Processos logísticos & Tempo Gasto & $\begin{array}{c}\text { Custo Adicional } \\
\text { (R\$) }\end{array}$ & $\begin{array}{c}\text { Custo } \\
\text { Adicional por } \\
\text { Saca }(\%) \\
\end{array}$ \\
\hline $\begin{array}{l}\text { Limpeza do caminhão para o } \\
\text { carregamento do adubo na empresa } \\
\text { fornecedora }\end{array}$ & $\begin{array}{l}30 \text { min por } \\
\text { caminhão }\end{array}$ & $\begin{array}{l}\mathrm{R} \$ 20,00 \text { por } \\
\text { caminhão }\end{array}$ & 0,34 \\
\hline $\begin{array}{l}\text { Limpeza do caminhão para o } \\
\text { carregamento da soja livre de transgênicos } \\
\text { na fazenda do produtor }\end{array}$ & $\begin{array}{l}30 \text { min por } \\
\text { caminhão }\end{array}$ & $\begin{array}{l}\mathrm{R} \$ 20,00 \text { por } \\
\text { caminhão }\end{array}$ & 0,34 \\
\hline $\begin{array}{l}\text { Tempo de espera para o carregamento dos } \\
\text { outros caminhões que irão transportar soja } \\
\text { transgênica na fazenda do produtor }\end{array}$ & $\begin{array}{l}40 \text { min por } \\
\text { caminhão }\end{array}$ & $\begin{array}{l}\mathrm{R} \$ 12,00 \text { por } \\
\text { caminhão (custo } \\
\text { da espera) }\end{array}$ & 0,2 \\
\hline $\begin{array}{l}\text { Tempo de espera para a realização do teste } \\
\text { de transgenia (SGS) antes do } \\
\text { carregamento da soja livre de transgênicos } \\
\text { na fazenda do produtor }\end{array}$ & 15 min por teste & $\begin{array}{l}\mathrm{R} \$ 4,50 \text { por teste } \\
\text { (custo da espera) }\end{array}$ & 0,08 \\
\hline $\begin{array}{l}\text { Tempo de espera para o descarregamento } \\
\text { dos caminhões no } \\
\text { armazenador/processador s que } \\
\text { transportaram soja transgênica }\end{array}$ & $\begin{array}{l}40 \text { min por } \\
\text { caminhão }\end{array}$ & $\begin{array}{l}\mathrm{R} \$ 12,00 \text { por } \\
\text { caminhão (custo } \\
\text { da espera) }\end{array}$ & 0,2 \\
\hline $\begin{array}{l}\text { Tempo de espera para a realização do teste } \\
\text { de transgenia (SGS) antes do } \\
\text { descarregamento da soja no } \\
\text { armazenador/processador }\end{array}$ & 15 min por teste & $\begin{array}{l}\mathrm{R} \$ 4,50 \text { por teste } \\
\text { (custo da espera) }\end{array}$ & 0,08 \\
\hline $\begin{array}{l}\text { Limpeza do caminhão para o } \\
\text { carregamento da soja livre de transgênicos } \\
\text { no armazenador/processador que será } \\
\text { enviada para o porto }\end{array}$ & $\begin{array}{l}30 \text { min por } \\
\text { caminhão }\end{array}$ & $\begin{array}{l}\mathrm{R} \$ 20,00 \text { por } \\
\text { caminhão }\end{array}$ & 0,34 \\
\hline $\begin{array}{l}\text { Tempo de espera para o carregamento dos } \\
\text { outros caminhões que irão transportar soja } \\
\text { transgênica até o porto }\end{array}$ & $\begin{array}{l}40 \text { min por } \\
\text { caminhão }\end{array}$ & $\begin{array}{c}\mathrm{R} \$ 12,00 \text { por } \\
\text { caminhão (custo } \\
\text { da espera) }\end{array}$ & 0,2 \\
\hline $\begin{array}{l}\text { Tempo de espera para a realização do teste } \\
\text { de transgenia (SGS) antes do } \\
\text { carregamento da soja no } \\
\text { armazenador/processador para ser } \\
\text { transportado até porto }\end{array}$ & 15 min por teste & $\begin{array}{l}\mathrm{R} \$ 4,50 \text { por teste } \\
\text { (custo da espera) }\end{array}$ & 0,08 \\
\hline $\begin{array}{l}\text { Tempo de espera para descarregamento } \\
\text { dos caminhões no porto que transportaram } \\
\text { soja transgênica }\end{array}$ & $\begin{array}{l}40 \text { min por } \\
\text { caminhão }\end{array}$ & $\begin{array}{l}\mathrm{R} \$ 12,00 \text { por } \\
\text { caminhão (custo } \\
\text { da espera) }\end{array}$ & 0,2 \\
\hline $\begin{array}{l}\text { Tempo de espera para a realização do teste } \\
\text { de transgenia (SGS) antes do } \\
\text { descarregamento do caminhão de soja no } \\
\text { porto }\end{array}$ & 15 min por teste & $\begin{array}{l}\mathrm{R} \$ 4,50 \text { por teste } \\
\text { (custo da espera) }\end{array}$ & 0,08 \\
\hline \multicolumn{3}{|c|}{ Custo Total da Segregação } & $2,14 \%$ \\
\hline
\end{tabular}

Fonte: Dados da pesquisa (2014)

Os transportadores rodoviários informaram não receber prêmio para realizar os processos necessários de segregação da soja ao longo da cadeia, citados anteriormente. Eles recebem apenas o frete pelo transporte da soja convencional, e segundo eles informaram, não há valor diferenciado em comparação ao frete da soja transgênica, conforme também pôde ser constatado nos resultados encontrados na primeira etapa da 
pesquisa. No entanto, assumem o custo da segregação, que também podem ser considerados como custos de transação (custo da limpeza e espera dos testes), os quais são de $2,14 \%$ por cada saca de soja convencional.

A Tabela 5.5 mostra os tempos e custos adicionais encontrados nos processos que dizem respeito aos operadores ferroviários dentro da cadeia logística da soja. Os dados apresentados foram extraídos de entrevistas com 3 operadores ferroviários na segunda etapa da pesquisa, conforme definido na metodologia do trabalho.

Tabela 5.5: Tempos e custos adicionais para os transportadores ferroviários fazerem a segregação da soja

\begin{tabular}{l|c|c|c}
\hline \hline \multicolumn{1}{c|}{ Processos logísticos } & Tempo Gasto & $\begin{array}{c}\text { Custo Adicional } \\
(\mathbf{R} \$)\end{array}$ & $\begin{array}{c}\text { Custo } \\
\text { Adicional por } \\
\text { Saca (\%) }\end{array}$ \\
\hline $\begin{array}{l}\text { Limpeza dos contêineres do trem antes do } \\
\text { carregamento da soja livre de transgênicos }\end{array}$ & 20 min por contêiner & $\begin{array}{c}\mathrm{R} \$ 20,00 \text { por } \\
\text { contêiner }\end{array}$ & 0,17 \\
\hline $\begin{array}{l}\text { Tempo de espera para a realização do teste } \\
\text { de transgenia (SGS) antes do } \\
\text { carregamento da soja nos contêineres do } \\
\text { trem }\end{array}$ & 15 min por teste & $\begin{array}{c}\mathrm{R} \$ 4,5 \text { por teste } \\
\text { custo da espera) }\end{array}$ & 0,04 \\
\hline $\begin{array}{l}\text { Tempo de espera para o carregamento dos } \\
\text { contêineres que irão transportar soja } \\
\text { transgênica }\end{array}$ & 5 min por contêiner & $\begin{array}{c}\mathrm{R} \$ 1,50 \text { por } \\
\text { contêiner (custo } \\
\text { da espera) }\end{array}$ & 0,01 \\
\hline $\begin{array}{l}\text { Depois que a soja chegar ao armazém no } \\
\text { porto, tempo de espera para a realização } \\
\text { do teste de transgenia (SGS) antes do } \\
\text { transbordo }\end{array}$ & 15 min por teste & $\begin{array}{c}\mathrm{R} \$ 4,50 \text { por teste } \\
\text { (custo da espera) }\end{array}$ & 0,04 \\
\hline $\begin{array}{l}\text { Tempo de espera para o transbordo dos } \\
\text { outros contêineres carregados com soja } \\
\text { transgênica }\end{array}$ & 15 min por contêiner & $\begin{array}{c}\mathrm{R} \$ 4,50 \text { por } \\
\text { contêiner (custo } \\
\text { da espera) }\end{array}$ & 0,04 \\
\hline \multicolumn{2}{c}{ Custo Total da Segregação } & & $\mathbf{0 , 3 \%}$ \\
\hline \hline
\end{tabular}

Fonte: Dados da pesquisa (2014)

Os transportadores ferroviários também informaram não receber prêmio para realizar os processos necessários à segregação da soja ao longo da cadeia. Eles recebem apenas o frete pelo transporte da soja convencional, e este não tem valor diferenciado em comparação com o frete da soja transgênica. No entanto, os transportadores assumem o custo da segregação, o qual é de $0,3 \%$ por cada saca de soja convencional.

A Tabela 5.6 mostra os tempos e custos adicionais encontrados nos processos que dizem respeito aos operadores portuários dentro da cadeia logística da soja. Os dados 
apresentados foram extraídos de entrevistas com 6 operadores portuários na segunda etapa da pesquisa, conforme definido na metodologia do trabalho.

Tabela 5.6: Tempos e custos adicionais para os operadores portuários fazerem a segregação da soja

\begin{tabular}{l|c|c|c}
\hline \hline \multicolumn{1}{c|}{ Processos logísticos } & Tempo Gasto & $\begin{array}{c}\text { Custo Adicional } \\
(\mathbf{R} \$)\end{array}$ & $\begin{array}{c}\text { Custo } \\
\text { Adicional por } \\
\text { Saca (\%) }\end{array}$ \\
\hline $\begin{array}{l}\text { Capacitação dos empregados e orientá-los } \\
\text { permanentemente sobre os cuidados e } \\
\text { procedimentos necessários para a limpeza } \\
\text { dos pátios e de todas as máquinas e } \\
\text { equipamentos necessários para a } \\
\text { segregação da soja livre de transgênicos }\end{array}$ & 365 dias ao ano & $\mathrm{R} \$ 10.000,00$ & $0,02 \%$ \\
\hline $\begin{array}{l}\text { Limpeza do pátio, e de todas as máquinas } \\
\text { e equipamentos do armazém necessários } \\
\text { para fazer a recepção e expedição da soja } \\
\text { livre de transgênicos }\end{array}$ & 10 dias ao ano & $\mathrm{R} \$ 3.600,00$ & 0,01 \\
\hline $\begin{array}{l}\text { Limpeza dos porões no navio para a } \\
\text { recepção da soja livre de transgênicos }\end{array}$ & 30 min por porão & $\mathrm{R} \$ 20,00$ & 0,005 \\
\hline $\begin{array}{l}\text { Tempo de espera para o carregamento dos } \\
\text { porões que irão transportar soja } \\
\text { transgênica até seu país de destino }\end{array}$ & 40 min por porão & $\mathrm{R} \$ 30,00$ & 0,005 \\
\hline $\begin{array}{l}\text { Teste de transgenia (SGS) antes do } \\
\text { carregamento da soja livre de transgênicos } \\
\text { no navio }\end{array}$ & & & \\
\hline \multicolumn{1}{c}{ Custo Total da Segregação } & $\mathrm{R} \$ 60,00$ & 0,005 \\
\hline \hline
\end{tabular}

Fonte: Dados da pesquisa (2014)

Foi constatado que os operadores portuários recebem, em média, R \$ 0,70 (1\%) por saca de soja para fazer a segregação da soja livre de transgênicos nos portos. Subtraindo este valor pelo levantado na Tabela 5.6, pode ser constatado que os operadores portuários recebem um prêmio real de $0,55 \%$ a mais por cada saca de soja segregada.

A Tabela 5.7 mostra resumidamente os resultados encontrados em relação aos tempos e custos adicionais para cada agente fazer a segregação. 
Tabela 5.7: Custos da segregação da cadeia logística da soja

\begin{tabular}{|c|c|c|c|}
\hline Elo Logístico & $\begin{array}{c}\text { Custo da } \\
\text { Segregação }(\%) \\
\end{array}$ & $\begin{array}{l}\text { Prêmio Recebido por } \\
\text { Saca de Soja }(\%)\end{array}$ & $\begin{array}{c}\text { Prêmio Real Recebido } \\
\text { por Saca de Soja }(\%)\end{array}$ \\
\hline Produtor Rural & 4,3 & 8,42 & 4,12 \\
\hline Armazenador/Processador & 1,2 & 11,4 & $9,2^{*}$ \\
\hline Transportador Rodoviário & 2,14 & 0 & $-2,14$ \\
\hline Operadores Ferroviários & 0,3 & 0 & $-0,3$ \\
\hline Operadores Portuários & 0,45 & 1 & 0,55 \\
\hline Total & 8,39 & & \\
\hline
\end{tabular}

Através da pesquisa de campo foi constatado que os custos da segregação de toda a cadeia logística da soja, para a oferta de um produto puro, livre de transgênicos, foram de $8,39 \%$; e que o armazenador/processador recebe um prêmio real de 9,2\% a mais por cada saca de soja pela segregação e gestão dos contratos ao longo da cadeia logística da soja.

O valor do prêmio real recebido pelos produtores rurais, armazenadores/processadores e operadores portuários parece ser compensatório para fazer a segregação da soja em cada elo logístico. Porém, se os investimentos em ativos físicos e humanos forem elevados, poderá desmotivar novos agentes a fazerem a segregação. Seria importante que os operadores rodoviários e ferroviários também recebessem o prêmio pelos cuidados que devem ser tomados nos processos logísticos, motivando-os a serem ainda mais meticulosos quando forem demandados a fazerem a segregação da soja.

Segundo dados coletados com os agentes entrevistados, pôde-se perceber que as informações sobre o valor do prêmio não estão sendo repassadas de forma clara aos agentes da cadeia, possivelmente porque os que estão ditando as "regras do jogo", notadamente os armazenadores/processadores, não têm interessem em fazê-lo para utilizar dessa informação assimétrica e agir oportunisticamente com os demais. Importante ressaltar que se as informações sobre o valor do prêmio fossem mais bem disseminadas entre os agentes ao longo da cadeia, e se o valor do prêmio pago pelo mercado internacional fosse distribuído de forma mais equitativa entre os agentes que fazem a segregação, certamente eles teriam maior motivação para fazer a segregação. 


\section{CONCLUSÕES E RECOMENDAÇÕES}

\subsection{APRESENTAÇÃO}

O objetivo deste capítulo é apresentar as principais conclusões e contribuições deste trabalho.

Inicialmente, são destacadas as limitações do estudo, verificadas em função de dificuldades encontradas ao longo de sua realização. Em seguida, são apresentadas as principais contribuições do trabalho. Posteriormente, são apresentadas as conclusões. E, finalizando o Capítulo, são expostas algumas recomendações e sugestões para futuras investigações relacionadas ao tema em questão.

\subsection{LIMITAÇÕES DO ESTUDO}

Uma limitação do estudo quanto ao levantamento do valor do prêmio recebido por cada agente para fazer a segregação da soja. Apenas os produtores rurais puderam fornecer dados com maior precisão sobre o que têm recebido. Mesmo diante disso, foi possível extrair informações que permitissem fazer as análises junto a todos os agentes entrevistados. Percebeu-se que essa é uma informação bastante sigilosa e que os agentes ficaram receosos no momento de relatar o valor do prêmio recebido.

A heterogeneidade dos vários agentes entrevistados, e principalmente de seus processos (não há padronização), também dificultou o levantamento dos dados e a análise dos resultados da pesquisa, notadamente no que diz respeito ao levantamento dos tempos e custos adicionais para a realização da segregação.

\subsection{CONTRIBUIÇÕES DO TRABALHO}

O objeto de estudo da presente tese foi a cadeia logística da soja. Procurou-se visualizar de forma sistêmica todas as variáveis que circundam o problema a ser analisado, e todos os elos envolvidos no processo, desde a compra da semente da soja até o seu deslocamento ao porto para exportação. Foram levadas em consideração as variáveis 
institucionais e as atividades logísticas primárias e de suporte envolvidas em todos os processos: transporte, processamento de pedidos, manutenção de estoque, armazenagem, obtenção, embalagem, manuseio, manutenção da informação e programação do produto.

A contribuição do trabalho foi identificar os elos logísticos com maior possilidade de contaminação da soja ao longo da cadeia, para posteriormente propor formas de se fazer a segregação, desde a compra da semente até a colocação do produto no navio para exportação. Isso só foi possível através da confecção dos fluxogramas, que ajudaram a visualizar como se dão os processos em toda a cadeia logística, para posterior levantamento de onde está ocorrendo a contaminação, e os cuidados e procedimentos necessários para a não contaminação. As informações do presente trabalho permitem que os agentes possam desenvolver estratégias que possibilitem a separação das duas sojas, garantindo a pureza do produto e o recebimento do prêmio.

O trabalho também trouxe informações sobre os tempos e os custos adicionais que os agentes assumem ao fazer a segregação. Foi feito um paralelo dos custos com o valor do prêmio recebido, para posteriormente demonstrar se vale a pena ou não financeiramente continuar fazendo essa separação.

Foi feita também uma análise do papel dos contratos na gestão da cadeia, e como suas salvaguardas ajudam ou podem ajudar os agentes que fazem a segregação, visando a garantir a oferta do produto livre de transgênicos e o recebimento do prêmio.

Essa abordagem sistêmica permitiu a identificação dos gargalos existentes na atual cadeia, fornecendo informações aos agentes da cadeia para a melhor compreensão dos problemas logísticos, com o intuito de contribuir com uma forma de organização de cadeia logística que minimize os problemas da contaminação e garanta a oferta do produto puro, livre de transgênicos.

As conclusões desta tese também podem ser utilizadas para que o Brasil possa colocar na agenda das políticas públicas o incentivo à continuidade da oferta da soja livre de transgênicos, porque se há países e mercados dispostos a pagar o prêmio, nosso país poderia se diferenciar dos demais e se consolidar como um grande exportador de soja 
livre de transgênicos, pois são poucos os países que conseguem oferecer esse produto de alto valor agregado.

Este é um trabalho inédito, porque reuniu uma quantidade de informações sobre variáveis que afetam diretamente a segregação da soja ao longo da cadeia logística, além de fornecer informações originais sobre tempos e custos logísticos que antes não eram encontrados na literatura especializada, assim como o valor do prêmio recebido por cada agente. Outra contribuição para o ineditismo do trabalho foi na confecção dos fluxogramas, pois não se conhecia os processos logísticos detalhadamente como estão apresentados no trabalho, mostrando onde há maiores problemas de contaminação e as estratégias para se fazer a segregação por cada agente ao longo da cadeia.

\subsection{CONCLUSÕES}

Os estudos realizados na presente tese permitiram tecer algumas conclusões e dar contribuições para o estado da arte da literatura.

Foi realizada uma análise sistêmica da cadeia logística da soja, identificando os gargalos existentes, principalmente no que tange à segregação e aos riscos de contaminação após o advento e a difusão da soja transgênica no Brasil. Como contribuição, foi possível identificar as etapas logísticas com maior possilidade de contaminação, e propor, por conseguinte, formas de se fazer a segregação, desde a compra da semente até a colocação do produto no navio para exportação. As informações levantadas auxiliam os agentes dessa cadeia a desenvolverem estratégias que possibilitem a separação das duas sojas, garantindo a pureza do produto e o recebimento do prêmio.

O primeiro objetivo específico desta tese foi alcançado, pois a estrutura e a lógica de toda a cadeia da soja foram mapeadas, identificando, com um olhar sistêmico, os problemas relacionados à segregação, sobretudo as variáveis que podem influenciar na contaminação, bem como os cuidados e procedimentos necessários à separação das duas sojas para a garantia da oferta de um produto puro.

No elo da produção rural, as etapas com maior risco de contaminação são: 1) compra da semente; 2) escolha da área correta para fazer o plantio; 3) preparo e a limpeza da área 
que será realizado o plantio; 4) planejamento e controle das bordas de contenção; 5) capacitação e orientações para os funcionários antes do plantio, colheita e armazenagem da soja; 6) limpeza das plantadeiras e colheitadeiras.

O principal cuidado que deve ser tomado pelos transportadores rodoviários é a limpeza do caminhão no momento do carregamento da soja livre de transgênicos em todas as fases da cadeia logística, desde a fazenda do produtor até sua chegada ao porto. Deve ser dada atenção também ao transbordo desta soja. Caso haja o descarregamento de outro caminhão com soja transgênica, concomitantemente se deve esperar até este processo ser finalizado, para somente depois iniciar o transbordo da soja convencional.

Os armazenadores/processadores devem fazer a limpeza em todas as suas instalações no momento da entrada e da saída da soja em seus armazéns, para não correrem o risco da contaminação, ou então destinar um armazém específico para a recepção da soja livre de transgênicos. Isso, porém, aumenta o investimento em ativos específicos destinados à segregação, e gera possível custo de ociosidade deste armazém, caso não haja a oferta do produto livre de transgênicos para armazenagem. Esses agentes também deveriam ser responsáveis pelo controle do carregamento e descarregamento individual dos caminhões, além da capacitação e orientação de seus funcionários quanto aos problemas da contaminação.

O principal cuidado a ser tomado pelos operadores ferroviários é a limpeza dos contêineres que transportam a soja livre de transgênicos, e o cuidado no momento do carregamento e transbordo, sendo necessário que sejam realizados individualmente.

O principal cuidado a ser tomado pelos operadores portuários é a limpeza dos porões que transportam a soja livre de transgênicos e o cuidado no momento do carregamento da soja no navio, sendo necessário ser realizado individualmente, além da capacitação e orientação de seus funcionários quanto aos problemas da contaminação.

Essas informações respondem ao segundo objetivo específico dessa tese.

O trabalho também trouxe informações sobre os tempos e os custos adicionais que os agentes assumem ao fazer a segregação. Através desse levantamento, concluiu-se que os 
custos para a segregação da soja convencional ao longo da cadeia logística são da ordem de $8,39 \%$ por saca. Sendo assim, essas informações respondem ao terceiro objetivo específico desta tese.

Também foi possível concluir que os contratos assumem papel primordial na mitigação dos riscos de contaminação, já que podem servir de mecanismos de incentivo/controle para que os agentes possam ser punidos/premiados pela segregação que é realizada ao longo da cadeia. Essas informações respondem ao quarto objetivo específico desta tese.

Vale ressaltar também a influência dos armazenadores/processadores nessa cadeia, utilizando de diversas estratégias para conseguirem a segregação internamente, e ao longo da cadeia. Eles podem ser vistos como o coordenador dos contratos dessa cadeia, ampliando seus limites no sentido "coaseano", amarrando contratos com todos os elos da cadeia logística para a garantia da entrega do produto livre de transgênicos aos mercados que a demandam, ditando o comportamento da cadeia, e recebendo um prêmio real de $9,2 \%$ pelo trabalho de segregação.

Nesse sentido, a necessária atividade de segregação, para permitir a oferta da soja livre de transgênicos, tem o seu custo apontado como empecilho para os agentes da cadeia. Contudo, parece estar delineado que se continuar havendo o pagamento do prêmio, estes agentes terão incentivos para continuar com a segregação da soja. O referido custo diz respeito não apenas às modificações técnicas nas fases de produção, transporte e armazenamento, mas também aos custos de transação em que incorrem os agentes envolvidos nessa cadeia, principalmente os custos relacionados aos tempos necessários para fazer cada operação adicional necessária à segregação e aos custos para a gestão dos contratos.

O trabalho também identificou todos os processos em que há maior possibilidade de contaminação ao longo da cadeia logística da soja. Além disso, foram propostas soluções logísticas, contratuais e de infraestrutura que permitem a redução desses riscos, facilitando a segregação do produto, e, consequentemente, a entrega de uma soja livre de transgênicos para os mercados que a demandarem. 
Importante ressaltar que o presente trabalho permitiu identificar a estrutura atual da cadeia logística da soja, mostrando todos os procedimentos necessários ao processo de segregação sem contaminação. Sendo assim, hoje, são conhecidos os processos ou as atividades ou elos da cadeia logística em que há maior possibilidade de contaminação. Além disso, foi identificado o que precisa ser feito para a não contaminação da soja convencional, e mensurados os custos e tempos adicionais necessários para implantar esses procedimentos ou processos numa cadeia logística que movimente os dois tipos de soja: a convencional e a transgênica. Com essas informações, os agentes que atualmente não fazem a segregação terão maior racionalidade para tomar sua decisão de aderir ou não à separação da soja.

Parece estar delineado que se continuar havendo o pagamento do prêmio aos agentes da cadeia logística da soja que já fazem a segregação, eles terão interesse em continuar fazendo a segregação. Contudo, para os "novos entrantes", o investimento em ativos humanos e físicos pode desestimular a segregação, pois os custos de saída são elevados, capitaneadas principalmente pelas incertezas inerentes ao pagamento do prêmio.

Seria relevante que as informações dentro da cadeia logística da soja fossem melhor disseminadas com todos os agentes, pois alguns deles que estão ganhando valores mais elevados, como os armazenadores/processadores, parecem não ter interesse em divulgar essas informações para o restante da cadeia. Isso aumenta os custos de transação ao longo da cadeia, através da racionalidade limitada dos outros agentes pela assimetria de informação que o armazenador/processador tem sobre os demais, configurando-se em oportunismo, pois utilizam de informações privilegiadas para levar vantagem em suastransações, principalmente sobre os transportadores rodoviários e ferroviários que não recebem o prêmio devido pela segregação da soja.

Mais uma vez, o poder de fazer valer seus interesses, parece estar com os elos mais fortes da cadeia, como o armazenador/processador, que ditará as "regras do jogo" caso a informação não seja disseminada de forma simétrica para todos os agentes.Está claro que os elos mais fracos da cadeia (produtores, transportadores rodoviários e ferroviários) acabam assumindo o ônus da segregação para que os mais fortes (armazenadores/processadores) possam tirar proveito dos ganhos advindos da não contaminação da soja. 
Sendo assim, o trabalho permitiu responder ao problema de pesquisa proposto, que foi o de identificar quais os cuidados e procedimentos necessários para fazer a segregação da soja convencional (GMO FREE) ao longo da cadeia logística, a fim de se garantir a oferta de um produto livre de transgênicos para os mercados que a demandarem. Contudo, não há necessidade de uma cadeia exclusiva para a soja convencional, desde que todos os procedimentos supracitados sejam realizados de forma bastante cautelosa para garantir a segregação do produto.

\subsection{RECOMENDAÇÕES PARA TRABALHOS FUTUROS}

Durante o desenvolvimento deste trabalho, foram identificadas oportunidades de estudos relacionadas ao tema em questão, os quais são destacados a seguir:

- Devido à heterogeneidade dos agentes envolvidos, seria interessante desenvolver modelagens com várias alternativas de segregação ao longo da cadeia logística, mostrando as que oferecem menores custos e riscos de contaminação;

- Estudos para definir qual é a melhor estrutura de governança a ser adotada em cada etapa apontada com risco de contaminação, a fim de minimizar os custos de transação ao longo da cadeia, pois alguns agentes estão fazendo investimentos em ativos específicos em ambientes de extremas incertezas.

- Devido à importância do papel dos contratos nos deslindes dos aspectos subjetivos cercados de sigilo e variáveis intangíveis, como o oportunismo e a incerteza, seria interessante o desenvolvimento em parceria com estudiosos da ciência da informação, notadamente na área de inteligência artificial para mitigar esses impactos. Para tanto, dentro da etapa de suporte da cadeia logística da soja, chamada de manutenção da informação, seria interessante desenvolver agentes inteligentes capazes de classificar níveis de incertezas na tomada de decisão, em função da ambiguidade das informações e do oportunismo.

- Desenvolver sistemas de informação pautados no fornecimento dos custos de segregação e do real valor do prêmio recebido, para que os agentes possam 
melhor gerenciar suas operações, tendo assim maior transparência na disseminação das informações para todos os agentes que necessitam destas para a redução de suas incertezas na tomada de decisão de segregar ou não segregar o produto.

- Com base nos valores dos custos levantados na pesquisa de campo, desenvolver uma análise financeira do custo/benefício em cada elo logísticos para saber se realmente vale a pena fazer a segregação da soja ao longo da cadeia logística. 


\section{REFERÊNCIAS BIBLIOGRÁFICAS}

AAMA - American Academy of Environmental Medicine. The American Academy Of

Environmental Medicine Calls For Immediate Moratorium On Genetically Modified Foods.

Disponível em: <http://www.stopogm.net/sites/stopogm.net/files/AAMApressrel.pdf>. Acesso em:

24 junho 2014.

ABIOVE - Associação Brasileira das Indústrias de Óleos Vegetais. Estatísticas. Disponível em:

<http://www.abiove.org.br/site/index.php?page=estatistica\&area=NC0yLTE=>. Acesso em: 20

abril de 2014.

ABRASEM - Associação Brasileira de Sementes e Mudas. Soja Transgênica Ocupa 90\% da área plantada. Disponível em: < http://www.abrasem.com.br/soja-transgenica-ocupa-90-da-areaplantada/>. Acesso em: 14 abril 2014.

ABRANGE - Associação Brasileira de Produtores de Grãos não Geneticamente Modificados. Disponível em: 〈http://planetaorganico.com.br/site/index.php/gmo-free-livre-de-transgenicos/>. Acesso em: 20 junho 2014.

ABRATES - Associação Brasileira de Tecnologia de Sementes. Soja Convencional pode se tornar Nicho de Mercado. Disponível em: < http://www.abrates.org.br/portal/edicoes-abrates-em-foco/8edicao-002/381-soja-convencional-pode-se-tornar-nicho-de-mercado>. Acesso em: 15 abril 2014.

AGROLINK.Transgênicos: rastreabilidade e segregação são garantias ao consumidor. Disponível em: 〈http://www.agrolink.com.br/sementes/NoticiaDetalhe.aspx?codNoticia=118763>. Acesso em: 20 julho 2013.

ANEC - Associação Nacional dos Exportadores de Cereais. Contratos. Disponível em: <http://www.anec.com.br/>. Acesso em: 10 janeiro 2014.

ANVISA - Agência Nacional de Vigilância Sanitária. Programa de Boas Práticas Regulatórias. Disponível em: <http://portal.anvisa.gov.br/wps/wcm/connect/d99af10040720ce7886fd8dc5a12ff52/Justificativa+ Altera\%C3\%A7\%C3\%A3o+do+252+\%2822-07\%29.pdf?MOD=AJPERES>. Acesso em: 21 junho 2014.

ALCHIAN, A.; DEMSETZ, H. Production, information coasts, and economic organization.American Economic Review. p. 777-795, 1972.

ALDIGUERI, D. R.; OLIVEIRA, A. R. G. Análise de trade-offsentre o escoamento imediato da Produção de soja e a armazenagem com escoamento controlado. In: Anais de Congresso da Associação Nacional de Pesquisa e Ensino em Transportes - ANPETT, 2009.

ALIAGA, F.; LUST, C. Violations of human rights as a result of GM soy.GMOs in agriculture again a theme on UN-committee of human rights. Geneva, 2011.

ALICEWEB/MDIC. Estatísticas de Comércio Exterior. Disponível em: <http://www.mdic.gov.br/sitio/interna/interna.php?area=5\&menu=1104>. Acesso em: 24 março 2014.

ALVARENGA, A. C. NOVAES. A. G. N. Logística Aplicada: suprimento e distribuição física. $3^{a}$ edição. São Paulo. Ed. Edgar Blucherltda, 2000. 
AMORIM, M. Clusters como estratégia de desenvolvimento industrial no Ceará. Fortaleza: Banco do Nordeste, ETENE, 1998. BRASIL. Decreto (15 de março de 2004). Plano de desenvolvimento regional sustentável para a área de influência da rodovia BR-163 Cuiabá-Santarém. Grupo de Trabalho Interministerial. Plano BR-163 Sustentável, junho de 2006. 185p.

ANTT - Agência Nacional de Transporte Terrestre. Disponível em: <http://www.antt.gov.br/>. Acesso em: 20 junho 2014.

APROSOJA - Associação dos Produtores de Mato Grosso. Estatísticas da Soja. Disponível em: <http://www.aprosoja.com.br/comissao/gestao-da-producao-e-de-propriedades/>. Acesso em: 16 março 2014.

ARAÚJO, N. B.; Wedekin, I.;Pinazza, L. A. Complexo agroindustrial: o agribusiness brasileiro. São Paulo: Agroceres. 1990. 238p.

ASA. Designer Soybeans. American Soybean Association. United Soybean Board, v.2. 2002.

AZEVEDO, P. F. Integração vertical e barganha. Tese de Doutorado - Faculdade de Economia, Administração e Ciências Contábeis, Universidade de São Paulo - USP, São Paulo,1996. Antecedentes In: FARINA, E.M.M.Q.; AZEVEDO, P.F.de.; SAES, M.S.M.

Competitividade: mercado, estado e organizações. São Paulo: Editora Singular, 1997. Nova economia institucional: referencial geral e aplicações para a agricultura. Mimeo, documento para discussão. São Carlos, 1999.

BALLOU, R. H. Logística empresarial: transportes, administração de materiais e distribuição física. Tradução: Hugo T. Y. Y. São Paulo: Altas, 1993.

Gerenciamento da cadeia de suprimento: planejamento, organização e logística empresarial. 4. ed. Porto Alegre: Bookman, 2001.

Gerenciamento da Cadeia de Suprimentos/logística empresarial. $5^{\text {a }}$ ed. Porto Alegre: Bookman. 2006.

BARONE, F. P.; OJIMA, A. L. R.A segregação dos grãos geneticamente modificados: desafios da logística para a movimentação da soja brasileira. In: XVI Congresso Interno de Iniciação Científica. Ginásio Multidisciplinar da UNICAMP, 2008.

BATAlHA, M. O. Gestão Agroindustrial. Atlas: São Paulo, 1997. Pontes, Do Carmo \&Porto . Problemas logísticos na exportação brasileira da soja em grão. SISTEMAS \& GESTÃO, v.4, n.2, p.155-181, maio a agosto de 2009.

BOUËT, A.; EBUCQUET, D.L.; DIENESCH, E.; ELLIOTT, K.The Costs and Benefits of Duty-Free, Quota-Free Market Access for Poor Countries: Who and What Matters. WorkingPaper 206. Center of Global Develoment, 2010.

BOWERSOX, D. J.; CLOSS, D. J. Logística Empresarial: O Processo de Integração da Cadeia de Suprimento. São Paulo: Atlas, 2001.

BOWERSOX, D.J; CLOSS, D.; COOPER, M.B. Gestão logística de cadeia de suprimentos. Porto Alegre: Bookman, 2006.

BRAGAGNOLO, C.; MAFIOLETTI, R. L.; SBRISSIA, G. F.; TURRA, F. E. Análise dos custos de produção da soja no Paraná: Convencional X Transgênica (RR). Anais... XLIII Congresso Brasileiro de economia e Sociologia Rural. SOBER. Londrina-PR: 2007. CD-ROM. 
BULLOCK; D.S. DESQUILBET, M . The economics of non-GMO segregation and identity preservation.Department of Agricultural and Consumer Economics, University of Illinois, 326 Mumford Hall, 1301 W. Gregory Drive, Urbana, IL 61801, USA. Institut National de la Recherche Agronomique, Economie et Sociologie Rurales rue Adolphe Bobierre, CS 61103, 35011 Rennes cedex, France, February 2002, Pages 81-99.

CARVALHO, J. M. C. Logística. 3ª ed. Lisboa: Edições Silabo, 2002.

CNA - Confederação da Agricultura e Pecuária do Brasil. Boletim Ativos de Grãos. Superintendência técnica da CNA - Confederação da Agricultura e Pecuária do Brasil e Centro de Estudos Avançados em Economia Aplicada - Cepea/Esalq. DADOS INTERNOS Ano 2, edição 2, 2008.

CNT. Confederação Nacional dos Transportes. Pesquisa CNT de Transporte Marítimo - 2012. Disponível em: <http://www.cnt.org.br/Paginas/Pesquisas_Detalhes.aspx?p=9>. Acesso em: 30 junho 2014.

Confederação Nacional dos Transportes. Pesquisa CNT de Ferrovias2011. Disponível em: <http://www.cnt.org.br/Paginas/Pesquisas_Detalhes.aspx?p=7>. Acesso em: 30 junho 2014.

Confederação Nacional dos Transportes. Pesquisa CNT de Rodovias 2013. Disponível em: <http://pesquisarodovias.cnt.org.br/Paginas/resumo.aspx>. Acesso em: 30 junho 2014.

COASE, R. Industrial Organization: a proposal for research. The Firm, The Market and The Law. The Universityof Chicago Press, part III, p.57-74, 1972.

COASE, R. H. The Nature of the Firm. Economican 4. November. 1937.”

COELI, C. C. M. Análise da demanda por transporte ferroviário: o caso do transporte de grãos e farelo de soja na ferronorte. Dissertação da Universidade Federal do Rio de Janeiro, Instituto COPPEAD de Administração, 2004.

COLENO, F. C. Simulation and evaluation of GM and non-GM segregation management strategies among European grain merchants. Jornal of food Engeenering. Volume 88, Issue 3, October 2008, Pages 306-314

COMISSÃO EUROPÉIA. Designações de produtos registrados. Disponível em: <www.europa.eu.int/comm/agriculture/ qual/pt/prod_pt.htm>. Acesso em: 10 maio 2013.

CONAB - Companhia Nacional de Abastecimento. Armazenagem no Brasil. Disponível em: <http:// www.conab.gov.br>. Acesso em: 4 dezembro 2013.

Companhia Nacional de Abastecimento. Acompanhamento da Safra Brasileira de Grãos 2012/2013. CONAB 2014. Disponível em< www.conab.com.br >. Acesso em: 16 julho 2014. .Companhia Nacional de Abastecimento .Conjuntura de Soja 2013. Disponível em: < http://www.agricultura.gov.br/arq_editor/file/camaras_setoriais/Soja/20RO/Apresentacao_Conjutur a_soja.pdf $>$. Acesso em: 25 março 2014.

CORREA JÚNIOR, G.; REZENDE, M. L.; MARTINS, R. S.; CAIXETA-FILHO, J. V. Fatores determinantes do valor do frete e o caso das centrais de cargas. In: CAIXETA-FILHO, J. V.; MARTINS, R. S. Gestão logística do transporte decargas. São Paulo: Atlas, 2001. cap. 4.

COSTA NETO, P. L. O. Estatística. São Paulo: Edgard Blücher, 1977. 264 p.

CURY, Antônio. Organização e métodos: uma visão holística: perspectiva comportamental \& abordagem contingencial. 7. ed. São Paulo: Atlas, 2000. 589 p. 
DAVIS, J. H.; GOLDBERG, R. A.A concept of agribusiness. Divisions of Research. Graduate School of Business Administration. Boston, Harvard University, 1957.

DORNIER, P.; ERNST, R.; FENDER, M.; KOUVELIS, P. Logística e operações globais: textos e casos. São Paulo. Ed. Atlas. 2000.

ESCOBAR, H. Área Plantada com Transgênicos no Mundo Cresce 3\%. O Estado de São Paulo. Disponível em: <http://economia.estadao.com.br/noticias/geral,area-plantada-com-transgenicos-nomundo-cresce-3,177814e>. Acesso em: 20 junho 2014.

ESPERANCINI, M. S. T.; FURLANETO, F. P. B.; RECO, P. C.; OJIMA, A. L. R. O.; YASUDA, G.M. Retorno e risco econômico no cultivo de soja convencional e transgênica na região paulista do médio Paranapanema, safra 2006/7.Anais... XLIII Congresso Brasileiro de economia e Sociologia Rural. SOBER. Rio Branco-AC: 2008. CD-ROM.

FARINA, E. M. M. Q. Capítulo de Apresentação In: FARINA, E.M.M.Q.; AZEVEDO, P.F.de.; SAES, M.S.M. Competitividade: mercado, estado e organizações. São Paulo: Editora Singular, 1997.

FERRARI, R. C. Utilização de modelo matemático de otimização para identificação de locais para instalação de unidades armazenadoras de soja no estado do Mato Grosso. Dissertação da Universidade de São Paulo: ESALQ, Piracicaba, 2006.

FIANI, R. Teorias dos custos de transação. In: KUPFER, D.; HASENCLEVER, L. (org.). Economia industrial - fundamentos teóricos e práticas no Brasil. Rio de Janeiro: Campos, 2002.

FERMENT, G.; ZANONI, M.; BRACK, P.; KAGEYAMA, P.; NODARI, R. O. Coexistência, o caso do milho. Proposta de Revisão da Resolução Normativa No 4 da CTNBIo. MDA, Brasília, 2009. Disponível em: <http://www.bs.cca.ufsc.br/publicacoes/coexistenciamilho.pdf\#page=1\&zoom=auto,639,847>. Acesso em: 02 outubro 2013.

FERNANDES, G.; FERMENT, G.; ZANONI, M.; LISBOA, M.; BRACK, P.; KAGEYAMA, P.; NODARI, R. O. Coexistência: o caso do milho. Nead/MDA, 2009.

FERRARI, R. C. Utilização de modelo matemático de otimização para identificação de locais para instalação de unidades armazenadoras de soja no estado do Mato Grosso. Dissertação da Universidade de São Paulo: ESALQ, Piracicaba, 2006.

FLEURY, P. F.; WANKE, P.; FIGUEIREDO, K. F. (Org). Logística Empresarial: a perspectiva brasileira. São Paulo. Ed. Atlas. 2000.

FLEURY, P. F. A infraestrutura e os desafios logísticos das exportações brasileiras. Disponível em <http://www.cel.coppead.ufrj.br>. Acesso em: 22 fevereiro 2014.

FLIGSTEIN, N. The architecture of markets: an economic sociology of twenty-first-century capitalist societies. United Kingdom: Princeton University Press, 2001.

FUSCALDI, K; MEDEIROS, J. X. ; PANTOJA, M J. Soja Convencional e Transgênica: percepção de atores do SAG da soja sobre esta coexistência .RESR, Piracicaba, SP, vol. 49, nº 04, p. 9911020, out/dez 2011 - Impressa em Janeiro de 2012.

GARCIA, J. L. e ROMEIRO, A. R. Governança da cadeia produtiva do biodiesel brasileiro. Revista de Política Agrícola, n. 1, p. 60-79, jan/mar. 2009.

GIL, A. C. Como elaborar projetos de Pesquisa. 5. ed. São Paulo: Atlas, 2010. 184 p. 
GLITZ, F. E. Z. A questão da bonificação. Estado de Minas - Caderno Agropecuário, Belo Horizonte, p. 2 - 2, 31 ago. 2009.

Transgênicos: A questão da bonificação. Portal do Agronegócio, Viçosa, 04 fev. 2011. GOODMAN, David; SORJ, Bernard; WILKINSON, John, Da lavoura às Biotecnologias- agricultura e indústria no sistema internacional. Rio de Janeiro: Campus, 1990.

GOULET F., VINCK D. Innovation through Withdrawal. Contribution to a Sociology of Detachment. Revue Française de Sociologie, vol. 53, n², p.117-146, 2012.

GREENPEACE. Transgênicos: perigo para a agricultura e para a humanidade. Disponível em: <http://www.greenpeace.org/brasil/pt/O-que-fazemos/Transgenicos/>. Acesso em: 26 junho 2014.

GROSSMAN, S.; HART, O. The Costs and Benefits of Ownership: a theory of Vertical and Lateral Integration. Journal of Political Economy, n. 94, p. 691-719, ago. 1986.

GUIA GEOGRÁFICO. Guia Geográfico, Mapa do Brasil. Disponível em: <http://www.guiageografico.com/mapas/mapa-brasil.htm>. Acesso em: 20 setembro 2013.

HARLAND, C.M. Supply Chain Management, Purchasing and Supply Management, Logistics, Vertical Integration, Materials Management and Supply Chain Dynamics. In: Slack, N (ed.) Blackwell Encyclopedic Dictionary of Operations Management. UK: Blackwell, 1996.

HART, O. e MOORE, J. Property Rights and the Nature of the Firm. Journal of Political Economy, n. 98, p. 1119-1158, dez. 1990.

HEINEMANN, J. A. Report on animals exposed to GM ingredients in animal feed. Prepared for th Commerce Commission of Ney Zealand, 2009.

HENESEY, L. PERSSON, J. A. Analyzing Transactions Costs in Transport Corridors Using Multi Agent-Based Simulation. Disponível em:

<http://www.igiglobal.com/viewtitlesample.aspx?id=26947>. Acesso em: 25 maio 2011.

HIJJAR, M. F.. Logística, soja e comércio internacional. Centro de Estudo em Logística. COPPEAD, UFRJ, Rio de Janeiro, 2004. Disponível em:<http://www.centrodelogistica.com.br/new/fspublic.htm>. Acesso em: 10 fevereiro 2007.

HUMPHREY, J. e SCHMITZ, H. Governance and upgrading: linking industrial clusters and global value chain research. IDS Working Paper, n. 120, p. 1-37, 2000.

IBGE - Instituto Brasileiro de Geografia e Estatística. Produção Agrícola Municipal: culturas temporárias e permanentes. 2010. Disponível em: <http://www.ibge.gov.br/home/estatistica/economia/pam/2010/PAM2010_Publicacao_completa.pd >.Acesso em: 20 janeiro 2014.

JOSKOW, P. L. Price adjustment in long-term contracts: the case of coal-burning electric generating plants. The Journal of Law and Economics, v. 31, abr. 1985.

JURAN, J.M.; GRYNA Jr., F.M. - Quality planning and analysis: from product development through usage. Nova Iorque: McGraw-Hill, 1970.

KEEDI, S. Logística de transporte internacional: veículo prático de competitividade. 1. ed. São Paulo: Aduaneiras, 2001.

LAVORENTI, G.B. Caracterização das vias de exportação de soja do estado do mato grosso. Grupo de Pesquisa e Extensão em Logística Agroindustrial - ESALQ-LOG, 2011. 
LEITÃO, F. O.; MEDEIROS, J. X.; RIBEIRO, J. G. B. L.; FOK, M. VILLAR, P. M. del. Análise da Percepção dos Armazenadores Processadores de Soja Sobre a Dinâmica da Soja GM e NGM. Artigo apresentado no seminário GICOGM. Brasília, 2007.

LEITÃO, F. O.; VILLAR, P. M.; FERREIRA, C. M.; RIBEIRO, J. G. B. L.; FOK, M.; MEDEIROS, J. X. ; GUERroUE, J. L. Coexistência da Soja Transgênica e Convencional no Brasil: o papel dos armazenadores/processadores na coordenação da cadeia produtiva da soja após o advento da soja transgênica. Cadernos do CEAM (UnB), v. 32, p. 123-158, 2008.

LEITÃO, F. O. Análise da coexistência da soja transgênica e convencional em Mato Grosso: rumo a novas formas de governança. Dissertação (Mestrado em Agronegócios)- UNB/DF, Brasília, 2009.

LEITÃO, F. O.;MEDEIROS, J. X. ; Thomé, K M.; CARVALHO, J. M.; BRISOLA, M. V. Cultivo de soja transgênica no mato grosso: fatores propulsores e limitativos. Revista de Economia Agrícola (Impresso), v. 57, p. 63-76, 2010.

LEITÃO, F. O. ; GRANEMANN, S. R.; THOMÉ, K. M.; ALMEIDA, R. E.O transporte e a armazenagem da soja após o advento dos transgênicos sob a ótica da nova economia institucional e da economia dos custos de transação. Revista Científica do INESC, v. 2, p. 1-16, 2012.

LESSA, V. Monsanto suspende cobrança de royalties da soja até decisão do STF. Site G1 .Disponível em: <http:/g1.globo.com/mato-grosso/noticia/2013/02/monsanto-suspende-cobranca-de-royaltiesMAPA. Ministério da Agricultura, Pecuária e Abastecimento. Soja. Disponível em: $<$ http://www.agricultura.gov.br/portal/page/portal/InternetMAPA/paginainicial/vegetal/culturas/soj a>. Acesso em: 17 maio 2013.

LEVINSON, D. ODLYZKO, A. Too expensive to meter: the influence of transaction costs in transportation and communication. Philosophical transactions of the Royal Society. 2008.

LIMA, C. L. B.;Evolução do agronegócio brasileiro, desafios e perspectivas. In: Observatorio de la Economía Latino americana, Número 118, 2009.

MALINARICH, H. D. Segregar a produção é garantia de qualidade para quem compra, e de rentabilidade para quem vende. Revista Grãos. Novembro de 2010.

MARQUES, P. V.; AGUIAR, D. R. D. Comercialização de produtos agrícolas. São Paulo: USP, 1993. $295 \mathrm{p}$.

MAPA - Ministério da Agricultura Pecuária e Abastecimento. Projeções do Agronegócio Mundial e Brasil até 2017. Brasília, 2006.

. Ministério da Agricultura, Pecuária e Abastecimento. CTNBIo. Disponível em: $<$ http://www.agricultura.gov.br/portal/page/portal/Internet-MAPA/paginainicial/vegetal/organismos-geneticamente-modificados/ctnbio>. Acesso em: 17 junho 2014.

MARTINS, P. C. Efeitos de políticas públicas sobre a cadeia produtiva de leite em pó. In: VIEIRA, R. C. M. T.;TEIXEIRA FILHO, A. R.; OLIVEIRA, A. J.; LOPES,M. R. (Ed). Cadeias produtivas no Brasil: Análise da competitividade. Brasília: Embrapa/Secretaria de Administração Estratégica, 2001. p. 239-272. 
MARTINS, R.S.; REBECHI, D.; PRATI, C.A.; CONTE, H. Decisões estratégicas na logística do agronegócio: compensação de custos transporte-armazenagem para a soja no estado do Paraná. RAC, v. 9, n. 1, Jan./Mar. 2005: 53-78

MARTINS, R.S.; XAVIER, W.S.; SPROESSER, R.L.; Custos de Transação nas Operações de Exportação de Café na Região Sul de Minas Gerais. Organizações Rurais \& Agroindustriais, Lavras, v. 12, n. 3, p. 411-422, 2010.

MEDEIROS, J. X.; RIBEIRO, J. G. B.; LEITÃO, F. O.; FOK, M.; MENDEZ DEL VILAR, P. Governança no SAG da soja após a difusão da soja GM: uma análise sob a ótica da Nova Economia Institucional. Anais... Artigo apresentado no seminário GICOGM. PROPAGA (Programa de Pós-Graduação em Agronegócios), Universidade de Brasília, 2007. CD-ROM.

MEDEIROS, J. X.; LEITÃO, F. O.; THOME, K. M.; BRISOLA, M. V. Mudanças Organizacionais no Sistema Agroindustrial da Soja com o Advento e a Difusão da Soja Transgênica. Anais... XLIII Congresso Brasileiro de economia e Sociologia Rural. SOBER. Campo Grande - MS: 2009. CDROM.

MENDEZ DEL VILAR, P.; FERREIRA, C. M.; RIBEIRO, J. G. B. L.; MEDEIROS, J. X.; LUBELLO, P.; FOK, M. "Private governance in royalty collection Effectiveness and limitations in tracing GM soybean in Brazil.” Third International Conference on Coexistence between Genetically Modified (GM) and non-GM based Agricultural Supply Chains, Sevilla, Spain, 2007.

MENDEZ, C. Déficit de armazenagem do Brasil passa de 50 milhões de toneladas. Disponível em: $<\mathrm{http} / / /$ www.noticiasagricolas.com.br/noticias/logistica/136502-deficit-de-armazenagem-do-brasilpassa-de-50-milhoes-de-toneladas.html\#.Uzr5UJHz-1s>. Acesso em: 20 março 2014.

MENEGATTI, A. L. A.; BARROS, A. L. M. Análise comparativa dos custos de produção entre soja transgênica e convencional: um estudo de caso para o Estado do Mato Grosso do Sul. Revista de Economia Rural. Vol.45. p. 163-183. Rio de Janeiro, 2007.

MINISTÉRIO DO MEIO AMBIENTE. Princípio da precaução. Disponível em: <http://www.mma.gov.br/biodiversidade/biosseguranca/item/7512-princ\%C3\%ADpio-daprecau\%C3\%A7\%C3\%A3o>. Acesso em: 17 junho 2014.

MYHR, A.I.; TRAAVIK, T. Genetically modified (GM) crops: precautionary science and conflicts of interests. Journal of Agricultural and Environmental Ethics, 16: 227-247, 2003.

NAVES, I. M.. Agronegócio e logística: dicotomia. XLV Congresso da SOBER - Sociedade Brasileira de Economia, Administração e Sociologia Rural. Londrina, 2007.

NOGUEIRA JUNIOR, S.; TSUNECHIRO, A. Produção Agrícola e Infraestrutura de Armazenagem no Brasil. Informações Econômicas, SP, V.35, n.2, Fev.2005.

NOVAES, A. G. Logística e gerenciamento da cadeia de distribuição: estratégia, operação e avaliação. 2.ed. Rio de Janeiro: Elsevier, 1993.

NORTH, D. C. Instituciones, cambio institucional y desempeño econômico. México: Fondo de Cultura Econômica, 1993. 190 p.

OJIMA, A. L. R. O. Análise da movimentação logística e competitividade da soja brasileira: uma aplicação de um modelo de equilíbrio espacial de programação quadrática. Universidade Estadual de Campinas, 2004. 
OLIVEIRA, A. L. R. O Sistema Logístico e os Impactos da Segregação dos Grãos Diferenciados:

Desafios para o Agronegócio Brasileiro. Tese de Doutorado. Universidade Estadual de

Campinas, Instituto de Economia, 2011.

OSAKI, M.; BATALHA, M. O. Mudança do sistema de produção da soja com o OGM. Anais... XLIII Congresso Brasileiro de economia e Sociologia Rural. SOBER. Londrina-PR: 2007. CD-ROM.

PLATA, L. Mercado de Terras no Brasil: Gênese, Determinação de seus Preços e Políticas, Tese de doutorado, 2001.

PONTES, H, L, J.; CARMO, B. B. T.; PORTO, A. J. V. Problemas logísticos na exportação brasileira da soja em grão. SISTEMAS \& GESTÃO, v.4, n.2, p.155-181, maio a agosto de 2009.

ROBESON, J. F.; COPACINO, W.C. The logistics handbook. Nova Iorque: The Free Press, 1994.

RUIJS, A. SCHWEIGMAN, C. LUTZ, C. The impact of transport- and transaction-cost reductions on food markets in developing countries: evidence for tempered expectations for Burkina Faso. Agricultural Economics. pg. 219-228, 2004.

SAMORA, R. Plantio de soja transgênica no Brasil atinge quase $90 \%$ do total. Disponível em: $<$ http://economia.uol.com.br/ultimas-noticias/reuters/2012/12/17/plantio-de-soja-transgenica-nobrasil-atinge-quase-90-do-total.jhtm>. Acesso em: 20 janeiro 2014.

SASSERON, J. L. Armazenamento de grãos. In: GOMES, R. A. R.; CASTRO, M. F. P.

M.;VALENTINI, S. R. T.; BOLONHEZI, S (Coord.). Atualização em tecnologia de pós-colheita de grãos. Campinas: Instituto de Tecnologia de Alimentos - ITAL, p.50-87, 1995.

SCHLECHT, S. M.; WILSON, W. W.; DAHL, B. L. Logistical Costs and Strategies for Wheat Segregation. Agribusiness \& Applied Economics Report No. 551, 2004.

SCHMITZ, H. Arranjos e Sistemas Produtivos Locais e as novas políticas de desenvolvimento industrial e tecnológico. Rio de Janeiro: UFRJ, 2000.

SCHNEIDER, A. V.; HOEFLICH, V. A.; KOCHE, L. M.; KOCHE, M. L. Análise de Filière da Cadeia Produtiva da Farinha de Trigo: um estudo de caso na Região Oeste do Paraná. Rio de Janeiro: UFRJ, 2000. Comunicação e Mercado/UNIGRAN - Dourados - MS, vol. 01, n. 03, p. 87-99, jul$\operatorname{dez} 2012$

SCHUSTER, I. Fluxo gênico e coexistência de lavouras com espécies transgênicas e convencionais. Informativo ABRATES, vol. 23, nº1, 2013.

SEAPA -Secretaria de Estado de Agricultura, Pecuária e Abastecimento. Estatísticas do Estado de Minas Gerais. Disponível em: <http://www.agricultura.mg.gov.br/>. Acesso em: 20 junho 2013.

SECRETARIA DOS PORTOS. R. Sistema Portuário Nacional. Disponível em: $<$ http://www.portosdobrasil.gov.br/assuntos-1/sistema-portuario-nacional>. Acesso em: 20 junho 2014.

SÉRALINI, G.E.; CELLIER, D.; VENDOMOIS, J.S. New analysis of a rat feeding study with a genetically modified maize reveals signs of hepatorenal toxicity. Archives of environmental contamination and toxicology, 2007.

SÉRALIN, G.E.; CLAIR, E.; MESNAGE, R.; GRESS, S.; DEFARGE, N.; MALATESTA, M.; HENNEQUIN, D.; VENDÔMOIS, J.S.. Long term toxicity of a Roundup herbicide and a Roundup-tolerant genetically modified maize. Food and Chemical Toxicology 50, 2012. 
SGS. Teste Genético. Disponível em:<http://www.sgsgroup.com.br/pt-BR/Agriculture-Food/Seed-andCrop/Seed-Services/Genetic-Testing.aspx>. Acesso em: 9 abril 2014.

SILVEIRA, J. M. F. J.; BORGES, I. C. Impactos Socioeconômicos da Difusão de OGM no Brasil. Anais... V International PENSA Conference on Agrifood Chains/Networks Economics and Management.Ribeirão Preto: 2005. CD-ROM.

SILVEIRA, J. V. F.; RESENDE, L, M. Estratégias de mercado no agronegócio paranaense: soja convencional vs. Transgênica. Produção, v. 20, n. 1, jan./mar. 2010, p. 54-65

SILVEIRA, J. M. J.; OLIVEIRA, A. L. R. Biotecnologia agrícola: impactos da segregação de grãos na competitividade brasileira. Conselho de Informações sobre Biotecnologia. Disponível em: $<$ http://cib.org.br/em-dia-com-a-ciencia/artigos/biotecnologia-agricola-impactos-da-segregacao-degraos-na-competitividade-brasileira/>. Acesso em: 20 maio 2013.

SIMON, H.A. Decision making and planning. In H.S. Perloff (Ed.), Planning and the urban community (Chap. 11). Pittsburgh: Carnegie Institute of Technology and the University of Pittsburgh Press, 1961.

SOUSA, E. L. L. Preservação de identidade de grãos e a coordenação dos sistemas agroindustriais. Tese de Doutorado. Escola Superior de Agricultura Luiz de Queiroz. 2001.

SOUZA, M. C. A. F. Commodities e especialidades. In: Gestão de Compras. Sebastião de Almeida Júnior. Editora Qualitymark, 2012.

TRANSPORTA BRASIL. Ao exigir segregação de transgênicos Portos Paranaenses se alinharam às leis nacionais e internacionais. Disponível em: < http://www.transportabrasil.com.br/2009/03/ao-exigirsegregacao-de-transgenicos-portos-paranaenses-se-alinharam-as-leis-nacionais-e-internacionais/> . Acesso em: 04 julho 2013.

VENDOMOIS, J.S.; ROULIER, F.; CELLIER, D.; SÉRALINI, G.E.A Comparison of the Effects of Three GM Corn Varieties on Mammalian. International Journal of Biological Sciences. 5(7):706-726, 2009.

VILARINHO, Maria Regina. Questões sanitárias e o agronegócio brasileiro. Disponível em: <http://www.embrapa.br/embrapa/ > . Acesso em: 09 maio 2014.

VILLA, J. C. Transaction cost in the transportation sector and infrastructure in North America: exploring harmonization of standards. CEPAL. International Trade and Industry Unit. México, D. F. 2007.

WIELAND, A.; WALLENBURG, C.M. Supply Chain Management in stürmischen Zeiten. Berlin, 2011.

WILKINSON, J.; PESSANHA, L. Transgênicos e a Competitividade Brasileira Face aos Desafios de Novas Formas de Coordenação nas Cadeias de Grãos. Anais... XLIII Congresso Brasileiro de economia e Sociologia Rural. SOBER. Ribeirão Preto: 2005. CD-ROM.

A Institucionalização Do Conflito Em Torno Da Biossegurança Dos Transgênicos Na Agricultura: Os Casos Do Brasil E Argentina. IV Encontro Nacional da Anppas 4,5 e 6 de junho de 2008. Brasília - DF - Brasil. Disponível em <http://www.anppas.org.br/encontro4/cd/ARQUIVOS/GT140913920080506133746.p>. Acesso em: 27 fevereiro 2013. 


\section{WILSON, W. DAHL, B. The Logistical Costs Of Marketing Identity Preserved Gm Wheat.}

Symposium "Product Differentiation and Market Segmentation in Grains and Oilseeds:

Implications for Industry in Transition". Sponsored by Economic Research Service, USDA and

The Farm Foundation. Washington, DC January 27-28, 2003.

WILLIAMSON, O. E. Markets and Hierarchies. New York: Free Press, 1975.

Instituciones economicas del capitalismo (las). México: Fondo de Cultura Economica, 1989. $435 \mathrm{p}$.

Comparative economic organization: the analysis of discret estructural alternatives.

Administrative Science Quarterly, v.36, p.269-96, Jun. 1991.

.B. Mercados y jerarquias: su análisis y sus implicaciones antitrust. México: Fondo de Cultura Econômica, 1991.

Transaction Cost Economics and Organization Theory. Journal of Industrial and

Corporate Change. n. 2, p. 107-156, 1993.

The mechanisms of governance. New York: Oxford University Press, 1999.

YIN, R. K. Estudo de caso: planejamento e métodos. 2. ed. Porto Alegre: Bookman, 2001. 205 p.

ZYLBERSTAJN, D. Estruturas de Governança e Coordenação do Agribusiness: Uma aplicação da

Nova Economia das Instituições. Tese de Livre Docência. FEA/USP. São Paulo, 1995.

Conceitos Gerais, Evolução e Apresentação do Sistema Agroindustrial. In:

ZYLBERSZTAJN, D.\& NEVES, M.F. (org.). Economia e Gestão dos Negócios

Agroalimentares. São Paulo, Pioneira, 2000.

Papel dos Contratos na Coordenação Agro Industrial: um olhar além dos mercados.

Artigo preparado para a conferência inaugural do Congresso da Sociedade Brasileira de Economia e Sociologia Rural - SOBER, Ribeirão Preto, 2005.

; LAZARRINI, S.G.; MACHADO FILHO, C.A.P. Avaliação dos impactos de variedades transgênicas no sistema agroindustrial da soja. Revista de Administração, São Paulo. V.34, n.3, p.21-31, julho/setembro, 1999.

.; FARINA, E. M.M.Q. Strictly coordinated food-systems: exploring the limits of the coasian firm. International Food and Agribusiness Management Review, 2, 249-265, 2009. 